\title{
CONSTITUTION OF URANIUM AND THORIUM ALLOYS
} Contract No. W-7405-eng-92

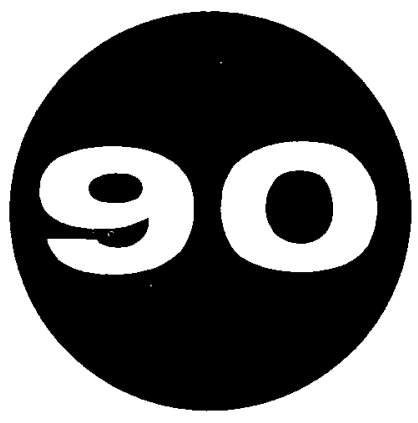

by

FRANK A. ROUGH ARTHUR A. BAUER

JUNE 2, 1958 


\section{DISCLAIMER}

This report was prepared as an account of work sponsored by an agency of the United States Government. Neither the United States Government nor any agency Thereof, nor any of their employees, makes any warranty, express or implied, or assumes any legal liability or responsibility for the accuracy, completeness, or usefulness of any information, apparatus, product, or process disclosed, or represents that its use would not infringe privately owned rights. Reference herein to any specific commercial product, process, or service by trade name, trademark, manufacturer, or otherwise does not necessarily constitute or imply its endorsement, recommendation, or favoring by the United States Government or any agency thereof. The views and opinions of authors expressed herein do not necessarily state or reflect those of the United States Government or any agency thereof. 


\section{DISCLAIMER}

Portions of this document may be illegible in electronic image products. Images are produced from the best available original document. 


\title{
PREFACE
}

\begin{abstract}
"Constitution of Uranium and Thorium Alloys" (BMI-1300) supersedes "Compilation of US and UK Uranium and Thorium Constitution Diagrams" (BMI-1000). It is a new reference piece in a modified format. The original "Compilation" has been used extensively and has been reprinted. The present authors believe that this degree of acceptance of the original work implies acceptance of the concept and approach. As a result, they have undertaken this "Compilation" in an attempt to provide an even more useful reference piece. Like its predecessor, this work was written with the cooperation of representatives of the United Kingdom.
\end{abstract}

The modified Metals Handbook system of notation for the diagrams employed in BMI-1000 was again used in preparing the se constitutional diagrams. The symbols a/o for atomic per cent and $w / 0$ for weight per cent have been used. In keeping with the general convention, phases have been designated beginning with the base. The inconvenience of having two alpha phases, alpha $A$ and alpha $B$, in the system $A-B$ is thereby obviated. Some slight but easily reconciled confusion may exist with previous data where the diagram may have been developed for the system B-A.

This "Compilation" is divided into two major sections, uranium alloys and thorium alloys. The major sections are preceded by a discussion of the transformation and melting temperatures of the base metal. Following the discussion are the various systems in alphabetical order. The major sections include both binary and ternary systems. In the previous edition the systems were separated on the basis of whether or not constitutional diagrams were available. For this "Compilation" it was determined that less weight should be given to the presence or absence of a diagram and that utilization of the information was most readily accomplished by a completely alphabetical listing.

Generally, only unclassified references have been used. However, because the unclassified literature is incomplete for several systems, some classified references are given. It is believed that future declassifications may make many now-classified references readily available.

The authors dedicate this volume to the late Henry A. Saller, one of the original editors. His interests and efforts in bringing the original "Compilation" into being have made this "Compilation" a much more straightforward task. 


\section{ACKNOWLEDGMENTS}

The authors are indebted to many of the personnel of the U.S. AEC and its con-

tractors. The presentation is basically a cooperative effort. Particular thanks are due E. Epremian, formerly of the U.S. AEC Research Division; G. K. Williamson and Miss J. R. Murray, The Atomic Energy Research Establishment, Harwell, England; and H. W. Russell, Battelle Memorial Institute, for their cooperation, guidance, and assistance. Grateful acknowledgment is made to C. R. Tipton, Jr., Battelle Memorial Institute, for his contribution to the organization and format of the presentation and to J. R. Doig, Battelle Memorial Institute, for his assistance in checking the crystallographic data. 


\section{TABLE OF CONTENTS}

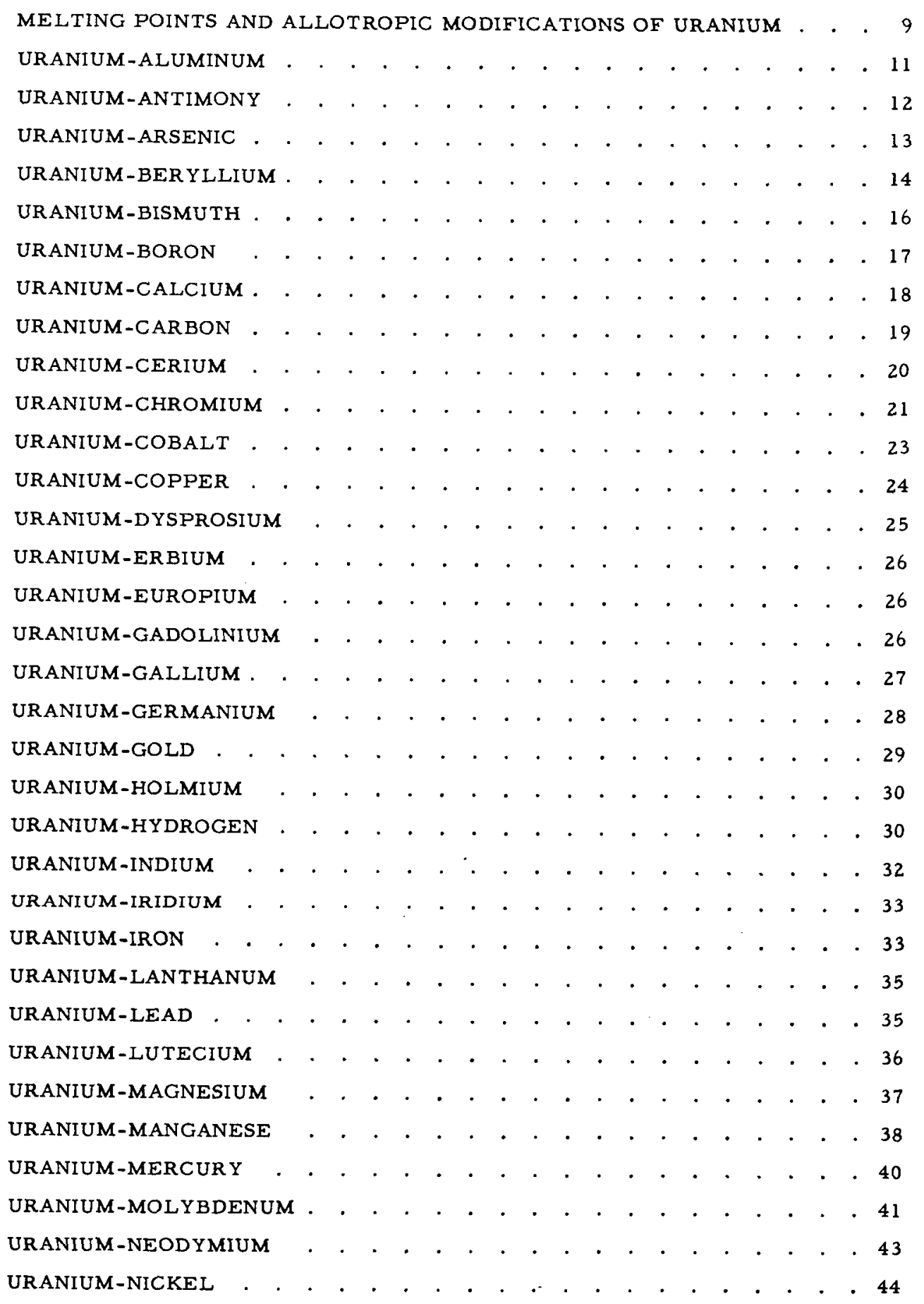




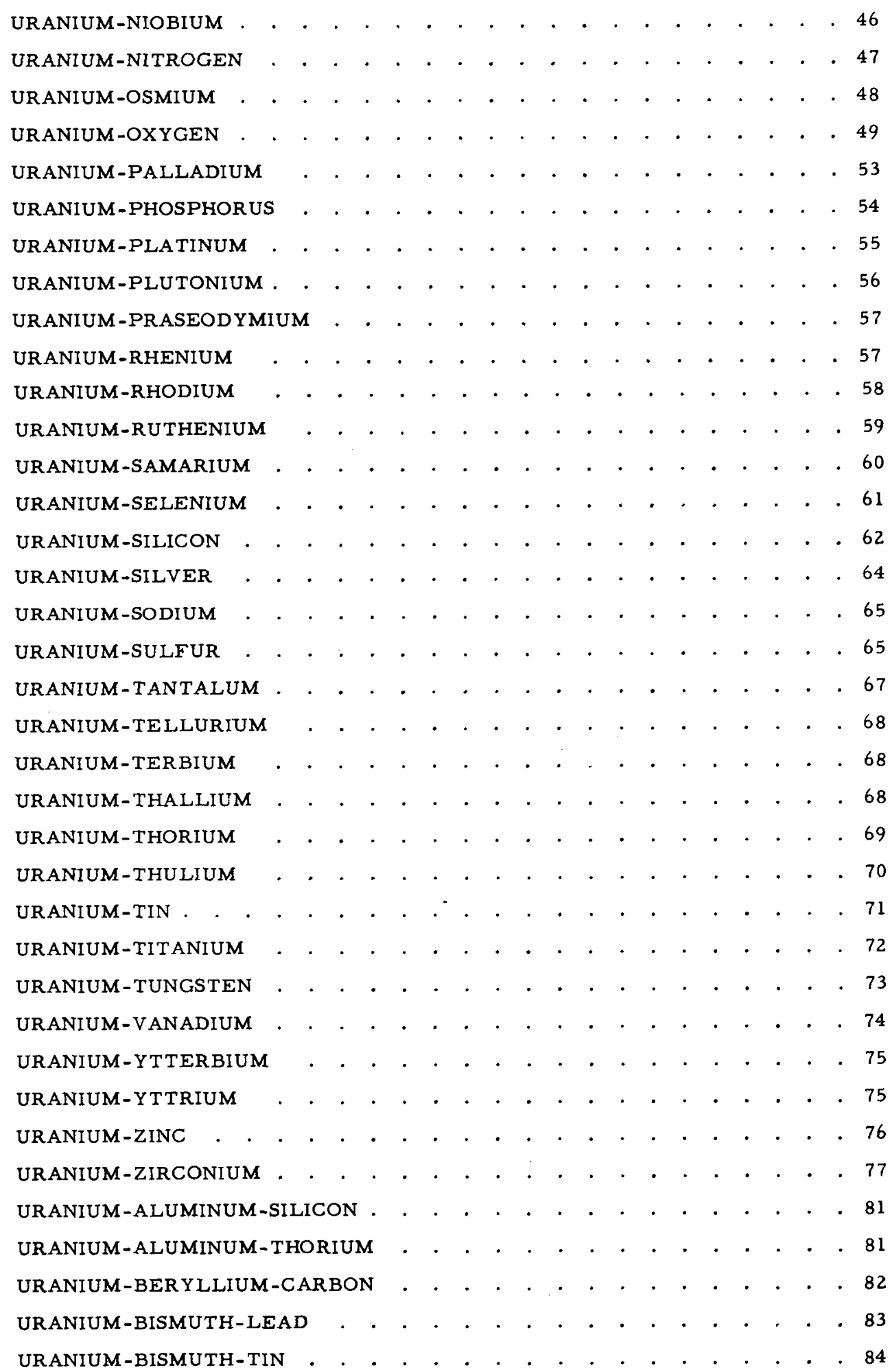


URANIUM-COBALT-NICKEL . . . . . . . . . . . . . . . . . 84 URANIUM-IRON-NICKEL . . . . . . . . . . . . . . . . . . 86

URANIUM-LEAD-TIN . . . . . . . . . . . . . . . . . . . . . 87

URANIUM-MANGANESE-NICKEL . . . . . . . . . . . . . . . . 88

URANIUM-MOLYBDENUM-NIOBIUM . . . . . . . . . . . . . . 89

URANIUM-MOLYBDENUM-RUTHENIUM . . . . . . . . . . . . . 89

URANIUM-MOLYBDENUM-TITANIUM . . . . . . . . . . . . . . . . . 90

URANIUM-NIOBIUM-ZIRCONIUM . . . . . . . . . . . . . . . 91

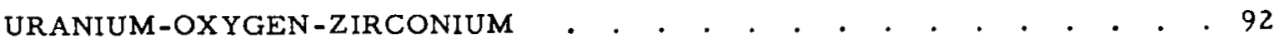

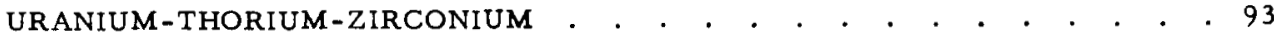

URANIUM - TITANIUM-ZIRCONIUM . . . . . . . . . . . . . . . . . . 94

MELTING POINTS AND ALLOTROPIC MODIFICATIONS OF THORIUM . . . 95

THORIUM-ALUMINUM . . . . . . . . . . . . . . . . . . . 97

THORIUM-ANTIMONY . . . . . . . . . . . . . . . . . . . 99

THORIUM-ARSENIC . . . . . . . . . . . . . . . . . . . . 99

THORIUM-BERYLLIUM . . . . . . . . . . . . . . . . . 100

THORIUM-BISMUTH . . . . . . . . . . . . . . . . . . . . 101

THORIUM-BORON . . . . . . . . . . . . . . . . . . . 103

THROIUM-CARBON . . . . . . . . . . . . . . . . . . . 104

THORIUM-CERIUM . . . . . . . . . . . . . . . . . . . . 106

THORIUM-CHROMIUM . . . . . . . . . . . . . . . . . . 107

THORIUM-COBALT . . . . . . . . . . . . . . . . . . . 107

THORIUM-COPPER . . . . . . . . . . . . . . . . . . . 109

THORIUM-GOLD . . . . . . . . . . . . . . . . . . . . . 110

THORIUM-HAFNIUM . . . . . . . . . . . . . . . . . . . 111

THORIUM-HYDROGEN . . . . . . . . . . . . . . . . . . 112

THORIUM-INDIUM . . . . . . . . . . . . . . . . . . . 112

THORIUM-IRIDIUM . . . . . . . . . . . . . . . . . . . 113

THORIUM-IRON . . . . . . . . . . . . . . . . . . . . 113

THORIUM-LANTHANUM . . . . . . . . . . . . . . . . . . . 114

THORIUM-LEAD . . . . . . . . . . . . . . . . . . . . 114

THORIUM-MAGNESIUM . . . . . . . . . . . . . . . . . 115

THORIUM-MANGANESE . . . . . . . . . . . . . . . . . 116

THORIUM-MERCURY . . . . . . . . . . . . . . . . . . 117

THORIUM-MOLYBDENUM . . . . . . . . . . . . . . . . . 118

THORIUM-NICKEL . . . . . . . . . . . . . . . . . . . 119 


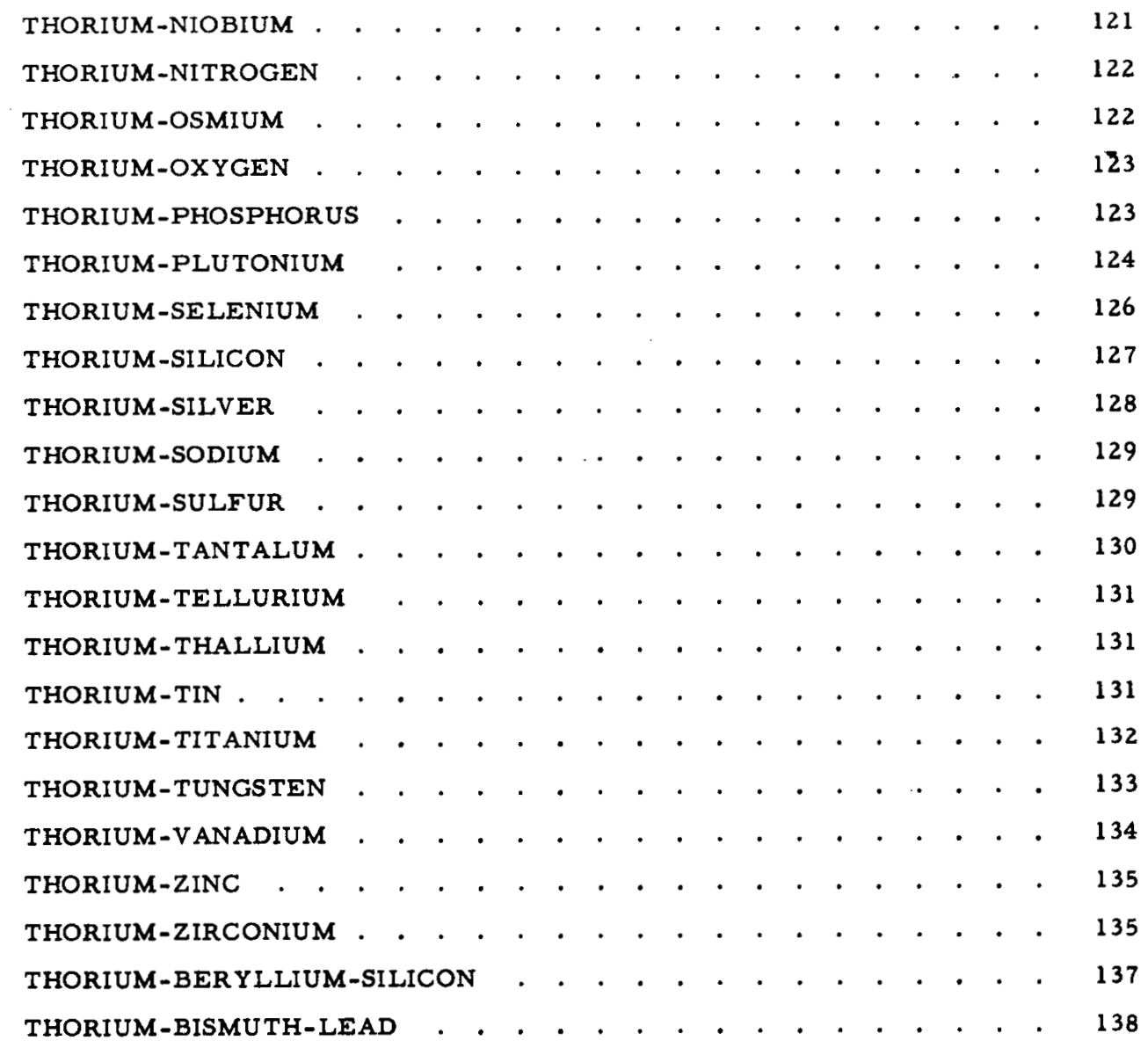




\section{MELTING POINTS AND ALLOTROPIC MODIFICATIONS OF URANIUM}

Reliable reports of the melting point and transformation temperatures of uranium are available in the literature(1). Further, uranium of ultrahigh purity has been prepared and studied by thermal analysis(2). The melting point and transformation temperatures which were determined are shown below.

Melting point

Beta-gamma transformation

Alpha-beta transformation

\begin{tabular}{rrr}
\multicolumn{3}{c}{ Temperature, C } \\
\hline Heating & Cooling & Average \\
\cline { 2 - 3 } 1128.7 & 1129.0 & 1128.9 \\
772.1 & 766.7 & 769.4 \\
667.1 & 657.7 & 662.4
\end{tabular}

In order to standardize the construction of diagrams, the average values shown above have been used throughout this volume as the transformation temperatures and melting point of uranium.

The crystal structure of alpha uranium has been determined to be orthorhombic by Jacob and Warren (3), using X-ray powder methods. The data on alpha in the tabulation on page 10 are from their work. Study by Lukesh ${ }^{(4)}$ has confirmed these data on single crystals or uranium.

The structure of alpha uranium may be regarded as being formed by the stacking of corrugated sheets. The binding within the corrugated sheets is largely covalent in nature(5).

The crystal structure of beta uranium is complex and of tetragonal symmetry. Although it was not until recent years that the structure was known to be tetragonal, the major contributors are now in reasonably close agreement about it. The analysis of the structure of beta uranium has been accomplished by two different techniques. Tucker ${ }^{(6)}$ has studied it at room temperature, using single crystals of retained beta in a 1.4 a/o chromium alloy. Thewlis $(7)$ has studied beta both in pure uranium and in the $1.4 \mathrm{a} / 0$ chromium alloy at $720 \mathrm{C}$ by high-temperature powder techniques.

Thewlis (7) reports that there are differences in intensity between beta powder patterns of the pure metal and those of the low-chromium alloy at $720 \mathrm{C}$. Tucker and Senio(8) report that the major discrepancy reported by Thewlis for the powder pattern of the low-chromium alloy is not found in single-crystal data from a sample of identical composition. On this basis, Tucker and Senio( 8$)$ conclude that the patterns of the beta structure for the lowchromium alloy and for the pure metal are identical.

The lattice dimensions for beta tabulated below are from Thewlis (7), while the other data for beta are from Tucker and Senio(8). Tucker(6) reports unit-cell dimensions for single crystals of the $1.4 \mathrm{a} / \mathrm{o}$ chromium beta at room temperature to be $\mathrm{a}=10.52$ and $\mathrm{c}=5.57 \mathrm{~A}$, with a measured density of $18.697 \mathrm{~g} / \mathrm{cm}^{3}$. Similar data are reported by Thewlis (7), who gives lattice constants of $a=10.590 \pm 0.001$ and $c=5.634 \pm 0.001 \mathrm{~A}$ and a density of 18.56 $\mathrm{g} / \mathrm{cm}^{3}$. These latter data are probably the more precise, since they were obtained by means of powder techniques. At $720 \mathrm{C}$, the unit-cell dimensions of the 1.4 a $/ 0$ chromium beta, according to Thewlis (7), are $a=10.763 \pm 0.005$ and $c=5.652 \pm 0.005 \mathrm{~A}$, corresponding to a density of $17.93 \mathrm{~g} / \mathrm{cm}^{3}$.

The structure of gamma uranium has been shown to be body-centered cubic. The data tabulated below are from Thewlis $(10)$. X-ray data were obtained at $800 \mathrm{C}$, giving a lattice constant of $a=3.487 \mathrm{~A}(9)$.

Lattice constants were also determined for a series of alloys containing 17.3 to 31.2 a/o molybdenum which possessed a retained-gamma structure(9). A lattice constant of $a=$ $3.474 \mathrm{~A}$ at room temperature was determined by extrapolation of these data. Vegard's law was assumed to apply to this system. 


\begin{tabular}{|c|c|c|c|c|c|c|c|}
\hline \multirow[b]{3}{*}{ Phase } & \multicolumn{3}{|c|}{ Unit Cell } & & & \multirow{3}{*}{$\begin{array}{l}\text { Space } \\
\text { Group } \\
\end{array}$} & \multirow[b]{3}{*}{ Remarks } \\
\hline & \multirow[b]{2}{*}{ Type } & \multirow{2}{*}{$\begin{array}{c}\text { Dimensions, } \\
\mathrm{A}\end{array}$} & \multirow{2}{*}{$\begin{array}{c}\text { Number } \\
\text { of } \\
\text { Molecules } \\
\end{array}$} & \multicolumn{2}{|c|}{$\begin{array}{l}\text { Density, } \\
\mathrm{g} / \mathrm{cm}^{3}\end{array}$} & & \\
\hline & & & & $\mathrm{X}-\mathrm{Ray}$ & Other & & \\
\hline Alpha & $\begin{array}{l}\text { Ortho- } \\
\text { rhom- } \\
\text { bic }\end{array}$ & $\begin{array}{l}a=2.852 \\
b=5.865 \\
c=4.945\end{array}$ & 4 & 19.12 & & $\mathrm{Cmcm}$ & \\
\hline Beta & $\begin{array}{l}\text { Tetrag- } \\
\text { onal }\end{array}$ & $\begin{array}{l}a=10.759 \pm 0.001 \\
c=5.656 \pm 0.001\end{array}$ & 30 & 18.11 & & $\mathrm{P}_{4} / \mathrm{mnm}$ & Data for $720 \mathrm{C}$ \\
\hline Gamma & $\mathrm{BCC}$ & $a=3.524$ & 2 & 18.06 & & $I_{m} 3 m$ & Data for $805 \mathrm{C}$ \\
\hline
\end{tabular}

\section{$\underline{\text { References }}$}

(1) Dahl, A. I., and Cleaves, H. E., "The Freezing Point of Uranium", J. Research Nat1. Bur. Standards, 43, 513-17 (1949).

(2) Baumrucker, J. E., and Chiswick, H. H., unpublished information (March, 1953).

(3) Jacob, C. W., and Warren, B. E., "The Crystalline Structure of Uranium", J. Am. Chem. Soc., 59, 2588 (1937).

(4) Lukesh, Joseph S., "Note on the Structure of Uranium", Acta Cryst., 2, 420 (1949).

(5) Tucker, C. W. , Jr., "The Crystal Structures of Metallic Uranium", Trans. Am. Soc. Metals, 42, 762-70 (1950).

(6) Tucker, C. W., Jr., "The Crystal Structure of the Beta Phase of Uranium", Acta Cryst., 4, 425-31 (1951).

(7) Thewlis, J., "X-ray Powder Study of Beta-Uranium", Acta Cryst., 5, 790-794 (1952).

(8) Tucker, C. W., Jr., and Senio, Peter, "An Improved Determination of the Crystal Structure of Beta Uranium", Acta Cryst. , 6, 753-760 (1953).

(9) Wilson, A. S., and Rundle, R. E., "The Structures of Uranium Metal", Acta Cryst., $2,126-127$ (1949).

(10) Thewlis, J., "Structures of Uranium", Nature, 168, 198-199 (1951). 


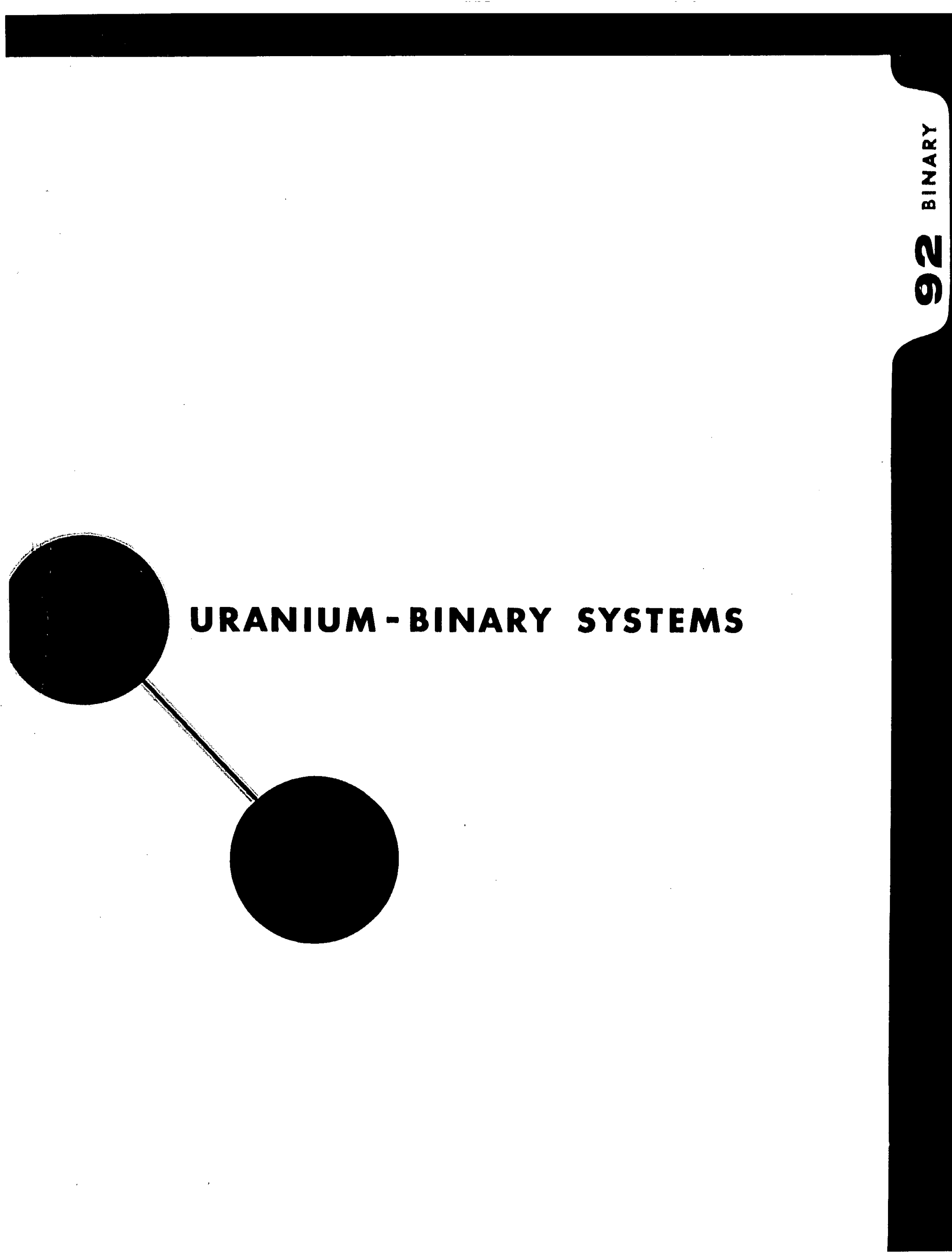




\section{URANIUM-ALUMINUM}

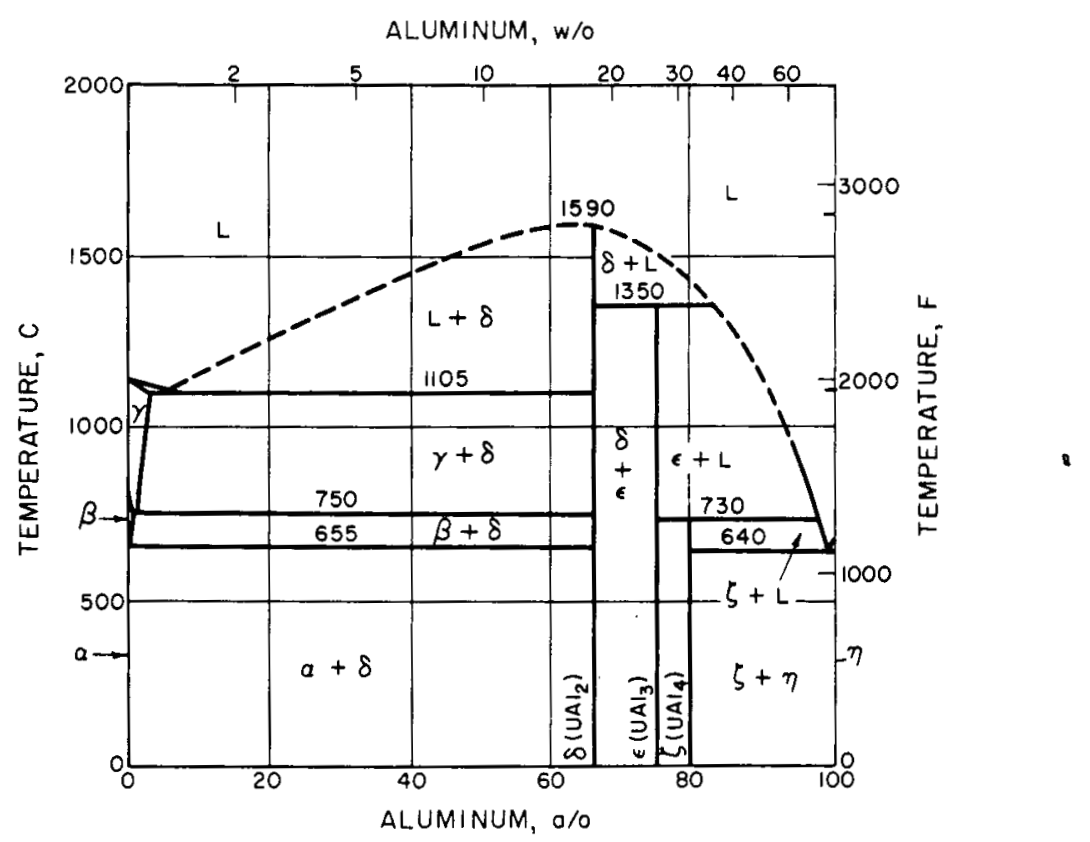

\section{The Constitutional Diagram}

There is virtually complete agreement on the uranium-aluminum system. The diagram shown is that of Gordon and Kaufmann(1), modified to include the UAl4 intermetallic compound reported by Borie(2) and Allen(3).

Minor differences exist between this diagram and that of Allen (3). These differences consist of small variations in the liquidus and in the various reaction isotherms. For example, at the uranium end of the system, Allen(3) reports values of 1123,757 , and $672 \mathrm{C}$ for the eutectic and eutectoid isotherms. The se values correspond to 1105,750 , and $655 \mathrm{C}$, respectively, in the diagram shown here. The work of Saller (4) is in agreement with the diagram shown. Thermal-analysis techniques resulted in slightly higher values for the aluminum-rich liquidus with $\mathrm{UAl}_{3}$, as reported by Storhok and Bauer(5):

$\begin{array}{rl}755 \mathrm{C} & 17 \mathrm{w} / \mathrm{o} \text { uranium } \\ 855 \mathrm{C} & 20 \mathrm{w} / 0 \text { uranium } \\ 954 \mathrm{C} & 24.5 \mathrm{w} / 0 \text { uranium } \\ 1068 \mathrm{C} & 30.9 \mathrm{w} / 0 \text { uranium } \\ 1190 \mathrm{C} & 41.7 \mathrm{w} / 0 \text { uranium } \\ 1265 \mathrm{C} & 51.2 \mathrm{w} / 0 \text { uranium }\end{array}$

Some details of the solubility of aluminum in uranium have been reported by Allen(3):
$980 \mathrm{C}$
$0.5 \mathrm{w} / 0$ aluminum
$800 \mathrm{C}$
0.2 w/o aluminum
$700 \mathrm{C}$
$0.11 \mathrm{w} / 0$ aluminum
$650 \mathrm{C}$
$<0.1 \mathrm{w} / 0$ aluminum

Similar values, perhaps slightly lower, can be scaled from diagram in the gamma-uranium region.

\section{Crystallography}

The crystallography of the intermetallic compounds is summarized in the tabulation below. The data shown for $\mathrm{UAl}_{2}$ and $\mathrm{UAl}_{3}$ are from the work of Rundle and Wilson(6). The structure of $\mathrm{UAI}_{3}$ is confirmed by Maskrey and Frost(7), although they report a lattice dimension of $a=4.27 \mathrm{~A}$. They also report that the atom positions of UAl3 are surely those of the $\mathrm{AuCu}_{3}$ ordered structure. On the basis of intensity data, it appears that a high degree of order exists in $\mathrm{UAl}_{3}$. 
Borie studied $\mathrm{UAl}_{4}$ (once identified as $\mathrm{UAl}_{5}{ }^{(1)}$ ) by both $\mathrm{X}$-ray and neutron diffraction. (2) Chemical analyses and density measurements were somewhat inconsistent with the $\mathrm{UAl}_{4}$ stoichiometry and structure. However, this inconsistency is explained on the basis of a defect lattice where some of the uranium sites are unoccupied or a re occupied by aluminum atoms. Analysis of the structure revealed that it can be described as plates of the cubic $\mathrm{UAl}_{3}$ structure held together by extra aluminum atoms (2).

\begin{tabular}{|c|c|c|c|c|c|c|c|}
\hline \multirow[b]{2}{*}{ Phase } & \multirow[b]{2}{*}{ Type } & Dimensions, & $\begin{array}{c}\text { Number } \\
\text { of }\end{array}$ & \multicolumn{2}{|c|}{$\begin{array}{r}\text { Density, } \\
\mathrm{g} / \mathrm{cm}^{3} \\
\end{array}$} & \multirow{2}{*}{$\begin{array}{l}\text { Space } \\
\text { Group } \\
\end{array}$} & \multirow[b]{2}{*}{ Remarks } \\
\hline & & $\mathrm{A}$ & Molecules & X-Ray & Other & & \\
\hline $\begin{array}{l}\text { Delta } \\
\left(\mathrm{UAI}_{2}\right)\end{array}$ & $\mathrm{Fcc}$ & $a=7.811$ & 8 & 8.14 & 8.2 & $\mathrm{Fd} 3 \mathrm{~m}$ & $\begin{array}{l}\text { Ci5-type } \mathrm{Cu}_{2} \mathrm{Mg} \text { struc- } \\
\text { ture }\end{array}$ \\
\hline $\begin{array}{l}\text { Epsilon } \\
\text { (UAl3) }\end{array}$ & $\begin{array}{r}\text { Simple } \\
\text { cubic }\end{array}$ & $a=4.287$ & 1 & 6.8 & & $\operatorname{Pm} 3 \mathrm{~m}$ & $\begin{array}{l}\text { Ordered, AuCu3-type } \\
\text { structure }\end{array}$ \\
\hline $\begin{array}{l}\text { Zeta } \\
\qquad\left(\mathrm{UAl}_{4}\right)\end{array}$ & $\begin{array}{l}\text { Ortho- } \\
\text { rhom- } \\
\text { bic }\end{array}$ & $\begin{array}{l}a=4.41 \\
b=6.27 \\
c=13.71\end{array}$ & 4 & & $5.7 \pm 0.3$ & $\begin{array}{l}\text { Ima or } \\
\text { Imma }\end{array}$ & \\
\hline
\end{tabular}

\section{References}

(1) Gordon, P., and Kaufmann, A. R., "The Alloy Systems Uranium-Aluminum and Uranium-Iron", J. Metals, 2, (1) 182 (1950).

(2) Borie, B. S., Jr., "Crystal Structure of UAl4", J. Metals, 3 (9), 800-802 (1951).

(3) Allen, N. P., United Kingdom, unpublished information (1947).

(4) Saller, H. A., Battelle Memorial Institute, "Preparation and Properties of AluminumUranium Alloys", TID-65, 9-19 (July, 1948). Classified.

(5) Storhok, V. W., and Bauer, A. A., private communication (1958).

(6) Rundle, R. E., and Wilson, A. S., "The Structures of Some Metal Compounds of Uranium" (AECD-2388), Acta. Cryst., 2, 148-50 (1949).

(7) Maskrey, J. T., and Frost, B. R. T., "The System Uranium-Lead" (AERE M/R 1027), J. Inst. Metals (12), 171-180 (1953).

\section{URANIUM-ANTIMONY}

There is evidence of a number of intermetallic compounds in the uranium antimony system. $(1,2,3)$ The following solubilities of uranium in liquid antimony have been reported(4):

$\begin{array}{lllllll}\text { Temperature, C } & 650 & 700 & 750 & 800 & 850 & 900 \\ \text { Solubility, w/o } & 0.1 & 0.3 & 0.5 & 0.8 & 1.8 & 2.9\end{array}$




\section{Crystallography}

The crystallography of $\mathrm{USb}, \mathrm{U}_{3} \mathrm{Sb}_{2}$, and $\mathrm{USb}_{2}$ compounds is reported by Ferro $(1,2)$ as shown below.

\begin{tabular}{|c|c|c|c|c|c|c|c|}
\hline \multirow[b]{3}{*}{ Phase } & \multicolumn{3}{|c|}{ Unit Cell } & \multirow{2}{*}{\multicolumn{2}{|c|}{$\begin{array}{r}\text { Density, } \\
\mathrm{g} / \mathrm{cm}^{3} \\
\end{array}$}} & \multirow{3}{*}{$\begin{array}{l}\text { Space } \\
\text { Group } \\
\end{array}$} & \multirow[b]{3}{*}{ Remarks } \\
\hline & \multirow[b]{2}{*}{ Type } & \multirow{2}{*}{$\begin{array}{c}\text { Dimensions, } \\
\mathrm{A} \\
\end{array}$} & \multirow{2}{*}{$\begin{array}{c}\text { Number } \\
\text { of } \\
\text { Molecules } \\
\end{array}$} & & & & \\
\hline & & & & X-Ray & Other & & \\
\hline $\mathrm{USb}$ & $F c c$ & $a=6.191$ & 4 & & & & $\begin{array}{l}\mathrm{NaCl} \text { structure; iso- } \\
\text { morphous with UN, } \\
\text { UP, and UAs }\end{array}$ \\
\hline $\mathrm{U}_{3} \mathrm{Sb}_{4}$ & Cubic & $a=9.095$ & & & & & \\
\hline $\mathrm{USb}_{2}$ & Tetragonal & $\begin{array}{l}a=4.272 \\
c=8.741\end{array}$ & & & & & \\
\hline
\end{tabular}

References

(1) Ferro, R., Atti accad. nazl. Lincei. Rend, Classe sci. fis., mat. e nat., 13, 53-61 (1952).

(2) Ferro, R., Atti accad. nazl. Lincei. Rend., Classe sci. fis., mat. e nat., 13, $151-157$ (1952).

(3) Katz, J. J., and Rabinowitch, E. , The Chemistry of Uranium, Part I, McGraw-Hill Book Company, Inc., New York (1951), pp 241-2.

(4) Hayes, E. E., and Gordon, P., TID-65, 130-141 (July, 1948). Classified.

\section{URANIUM-ARSENIC}

There is evidence supporting three intermetallic compounds in the uranium-arsenic system, but little else is known about these alloys.

\section{Crystallography}

The crystallography of UAs and UAs 2 compounds is summarized below. The data for UAs are those of Rundle(1). Ferro(2) reports that UAs is similar in structure to USb, UN, $\mathrm{UP}$, and UBi. $\mathrm{UAs}_{2}$.

On the basis of $X$-ray studies, Iandelli $(3,4)$ reports the existence of UAs, $U_{3} A s_{4}$, and

Katz and Rabinowitch(5) have surveyed information on this system.

\begin{tabular}{|c|c|c|c|c|c|c|}
\hline \multirow[b]{3}{*}{ Phase } & \multicolumn{3}{|c|}{ Unit Cell } & \multirow{2}{*}{\multicolumn{2}{|c|}{$\begin{array}{l}\text { Density } \\
\text { g/cm }\end{array}$}} & \multirow[b]{3}{*}{ Remarks } \\
\hline & \multirow[b]{2}{*}{ Type } & \multirow{2}{*}{$\begin{array}{c}\text { Dimensions, } \\
\mathrm{A}\end{array}$} & \multirow{2}{*}{$\begin{array}{c}\text { Number } \\
\text { of } \\
\text { Molecules } \\
\end{array}$} & & & \\
\hline & & & & X-Ray & Other & \\
\hline UAs & Fcc & $a=5.767 \pm 0.01$ & 4 & 10.77 & & $\begin{array}{l}\text { NaCl structure, iso- } \\
\text { morphous with rare- } \\
\text { earth arsenides of } \\
\mathrm{La}, \mathrm{Ce}, \mathrm{Pr}, \mathrm{Nd}\end{array}$ \\
\hline $\mathrm{UAs}_{2}$ & Tetragonal & $\begin{array}{l}a=3.954 \\
c=8.116\end{array}$ & 2 & 9.8 & & Isomorphous with $\mathrm{UP}_{2}$ \\
\hline
\end{tabular}


(1) Rundle, R. E., and Baenziger, N. C., unpublished information (1944).

(2) Ferro, R., Atti. accad. nazl. Lincei. Rend., Classe sci, fis., mat. e nat., 13, 53-61 (1952).

(3) Iandelli, A., "Uranium Arsenides II. Crystal Structure of UAs 2 and UP 2 ", Atti. accad. nazl. Lincei. Rend., Classe sci. fis, , mat. e nat., 13, 144-51 (1952).

(4) Iandelli, A., "Uranium Arsenides I", Atti. accad. nazl. Lincei. Rend., Classe sci. fis., mat. e nat., 13, 138-143 (1952).

(5) Katz, J. J., and Rabinowitch, E., The Chemistry of Uranium, Part I, McGraw-Hill Book Company, Inc, , New York (1951), pp 24l-2.

\section{URANIUM-BERYLLIUM}

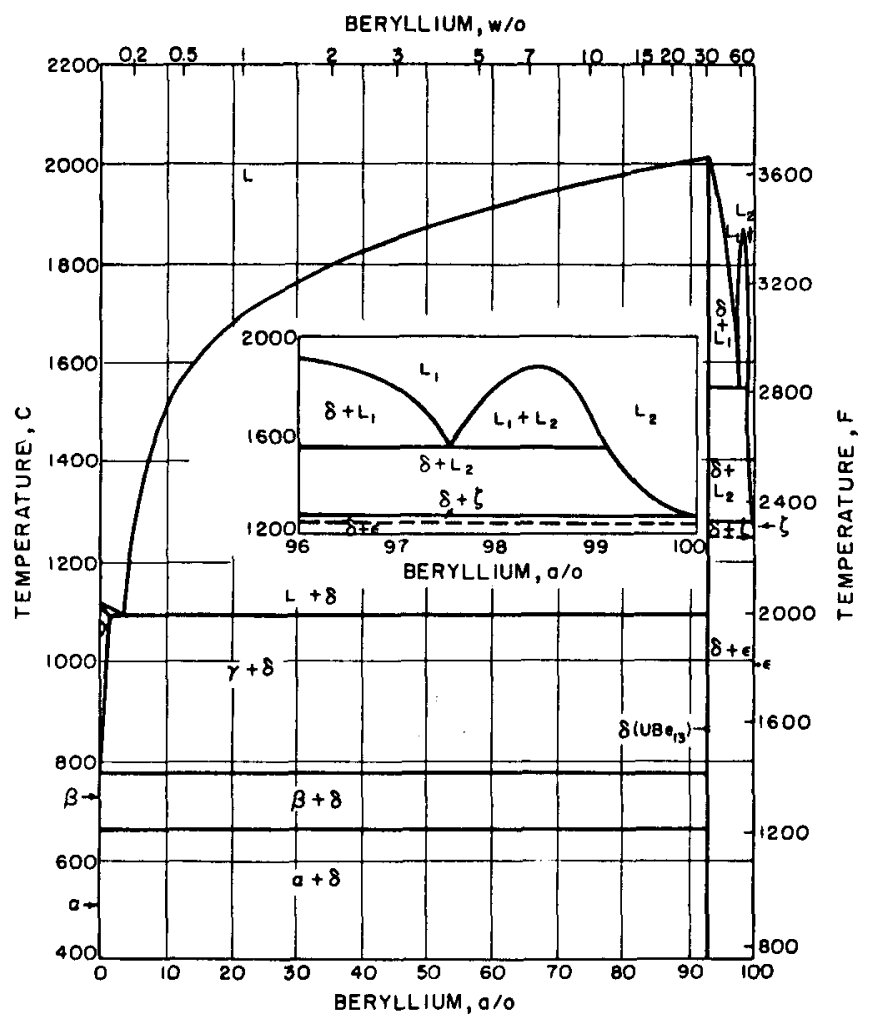

The Constitutional Diagram

The diagram shown here is the work of Buzzard and co-workers(1). It represents the results of much difficult and trying work, since the atomic-weight ratio of uranium to beryllium is very high. The work was further complicated by the high volatility of beryllium at elevated temperatures. In general, the less elaborate work of other investigators is in agreement with this diagram. No confirmation exists for the tentatively proposed hightemperature modification in beryllium, which is designated as zeta $(Q$ in the diagram. Details of the monotectic reaction are amplified in the inset of the diagram.

Buzzard reports that the eutectic between uranium and UBe 13 occurs at a composition of less than $5 \mathrm{a} / 0$ beryllium $(0.2 \mathrm{w} / \mathrm{o})$. He also reports that the solubility of beryllium in uranium is small and that of the solubility of uranium in beryllium has not been detected. (1)

The National Physical Laboratory reports that the solid solubility of beryllium in uranium is between 2.8 and 8.4 a/o beryllium. The beryllium-rich eutectic contains about 0.06 a $/ 0$ uranium(4). 
Data for UBel 3 are summarized in the accompanying tabulation $(2,3)$. There is no doubt that the unit cell is complex, although first studies tended to indicate a simple cubic structure with a lattice constant of about $5 \mathrm{~A}$. Baenziger and Rundle(2) studied a whole series of MBe 13 compounds where $M$ was uranium, thorium, cerium, and zirconium. Study of rota tion and Weissenberg diagrams of single crystals of $\mathrm{ZrBe} 13$ revealed the more complex structure. On closer inspection, they found that the (531) reflection, which requires the larger unit, could be seen on powder diagrams. Their data were calculated from backreflection data obtained with a symmetrical, self-focusing powder camera(2).

Koehler and co-workers(3) studied single crystals of UBe 13 by both X-ray-and neutrondiffraction methods. Their work is in complete agreement with that of Baenziger and Rundle(2).

\begin{tabular}{|c|c|c|c|c|c|c|c|}
\hline \multirow[b]{3}{*}{ Phase } & \multicolumn{3}{|c|}{ Unit Cell } & \multirow{2}{*}{\multicolumn{2}{|c|}{$\begin{array}{l}\text { Density, } \\
\text { g/ } / \mathrm{cm}^{3}\end{array}$}} & \multirow{3}{*}{$\begin{array}{l}\text { Space } \\
\text { Group }\end{array}$} & \multirow[b]{3}{*}{ Remarks } \\
\hline & \multirow[b]{2}{*}{ Type } & \multirow{2}{*}{$\begin{array}{c}\text { Dimensions, } \\
\text { A }\end{array}$} & \multirow{2}{*}{$\begin{array}{c}\text { Number } \\
\text { of } \\
\text { Molecules } \\
\end{array}$} & & & & \\
\hline & & & & $\mathrm{X}-\mathrm{Ray}$ & Other & & \\
\hline $\begin{array}{l}\text { Delta } \\
\text { (UBel } 3 \text { ) }\end{array}$ & $\mathrm{Fcc}$ & $a=10.2568$ & 8 & 4.373 & $\begin{array}{l}4.420 \pm \\
0.002 \\
\text { at } 260\end{array}$ & $\mathrm{Fm} 3 \mathrm{c}$ & $\begin{array}{l}\text { Isomorphous with } \\
\mathrm{NaZn}_{13}, \mathrm{ThBe}_{13}, \\
\mathrm{CeBe}_{13} \text {, and } \mathrm{ZrBe}_{1}\end{array}$ \\
\hline
\end{tabular}

\section{References}

(1) Buzzard, R. W., Sterling, J. T., Buzzard, E. A., and Darr, J. H. (AECD-3417), J. Res. Natl. Bur. Standards, 50, 63-67 (2), (1953).

(2) Baenziger, N. C., and Rundle, R. E., "The MBe 13 Compounds" (AECD-2506), Acta Cryst., 2, 258 (1949).

(3) Koehler, W. C., Singer, Joseph, and Coffinberry, A. S., "X-Ray and Neutron Diffraction Studies of the MBel 3 Intermetallic Compounds" (AECD-3298), Acta Cryst., 5, 394 (1952).

(4) National Physical Laboratory, United Kingdom, unpublished information (October, 1948). 


\section{URANIUM-BISMUTH}

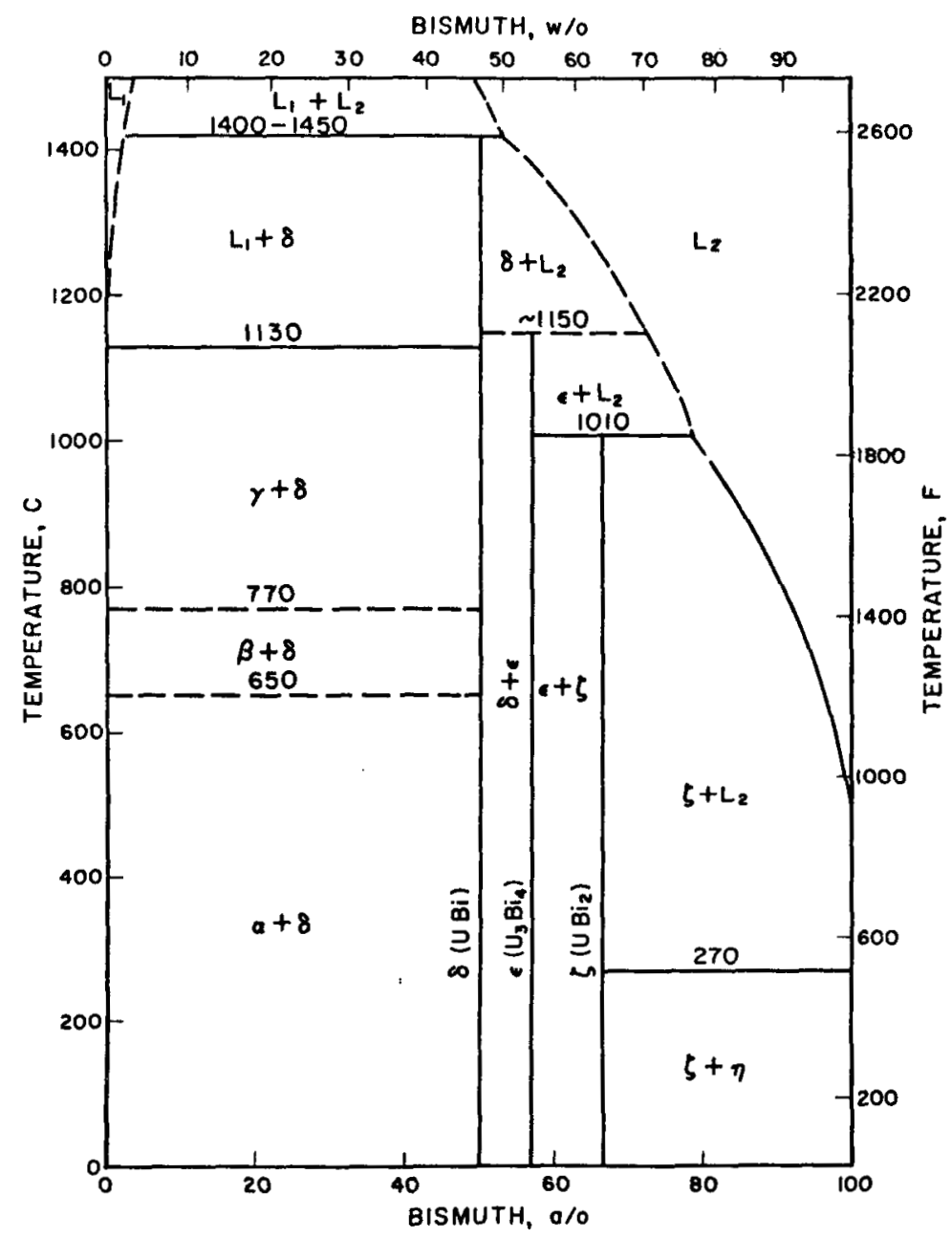

\section{The Constitutional Diagram}

The original study of the uranium-bismuth system was performed by Ahmann and Baldwin(1). Their data indicated the existence of two compounds, UBi and UBi2, and their diagram, although incomplete, had all the major features of the system as it is now interpreted. The work of Teitel(2) and Ferro(3) brought about revision of the system as it is shown here and identified the compounds as $\mathrm{UBi}, \mathrm{U}_{3} \mathrm{Bi}_{4}$, and $\mathrm{UBi} 2$.

Determinations of the solubility of uranium in bismuth by Greenwood(6), who used filtration, by Cotterill(7), who used thermal analysis, and by Bareis(8), who used filtration and flotation techniques, are substantially in agreement with the diagram as shown. Greenwood $(6)$ found the solubility obeyed the relationship $\log _{10}$ (uranium, w/o) $=3.00-\frac{2440}{\mathrm{~T}}$, where $T$ is the absolute temperature, and obtained the following values:

$\begin{array}{lllllllllll}\text { Temperature, C } & 515 & 546 & 602 & 668 & 722 & 760 & 796 & 816 & 898 & 960 \\ \text { Solubility, w/o } & 0.7 & 0.9 & 1.3 & 2.7 & 3.5 & 5.1 & 6.7 & 9.3 & 13.9 & 19.6\end{array}$

The values of Bareis(8) agree well with those of Greenwood, but since they cover a different temperature range, the values are given below:

$\begin{array}{lllllllllll}\text { Temperature, C } & 271 & 300 & 350 & 400 & 450 & 500 & 550 & 600 & 650 & 700 \\ \text { Solubility, w/0 } & 0.031 & 0.051 & 0.108 & 0.21 & 0.36 & 0.60 & 0.97 & 1.47 & 2.18 & 3.1\end{array}$




\section{Crystallography}

Data on the crystallography of the intermetallic compounds in this system are summarized in the tabulation below.

The structure of UBi is from the work of Teitel(2) and was determined by means of neutron-diffraction experiments. Both Ferro(3) and Brewer(4) have reported the UBi structure to be face-centered cubic and give lattice constants of $a=6.356 \mathrm{~A}$ and $\mathrm{a}=6.364 \mathrm{~A}$, respectively.

The data for $\mathrm{U}_{3} \mathrm{Bi}_{4}$ and for UBi2 are from the work of Ferro $(3,5)$.

\begin{tabular}{|c|c|c|c|c|c|c|c|}
\hline \multirow[b]{3}{*}{ Phase } & \multicolumn{3}{|c|}{ Unit Cell } & \multirow{2}{*}{\multicolumn{2}{|c|}{$\begin{array}{r}\text { Density, } \\
\mathrm{g} / \mathrm{cm}^{3} \\
\end{array}$}} & \multirow{3}{*}{$\begin{array}{l}\text { Space } \\
\text { Group }\end{array}$} & \multirow[b]{3}{*}{ Remarks } \\
\hline & & Dimensions, & $\begin{array}{c}\text { Number } \\
\text { of }\end{array}$ & & & & \\
\hline & Type & $\mathrm{A}$ & Molecules & X-Ray & Other & & \\
\hline $\begin{array}{l}\text { Delta } \\
\text { (UBi) }\end{array}$ & $\begin{array}{l}\text { Bc tetrag- } \\
\text { onal }\end{array}$ & $\begin{array}{l}a=11.12 \\
c=10.55\end{array}$ & 24 & 13.6 & & & \\
\hline $\begin{array}{l}\text { Epsilon } \\
\left(\mathrm{U}_{3} \mathrm{Bi}_{4}\right)\end{array}$ & Cubic & $a=9.350$ & 4 & 12.59 & & & \\
\hline $\begin{array}{l}\text { Zeta } \\
\text { (UBiz) }\end{array}$ & $\begin{array}{c}\text { Tetrag- } \\
\text { onal }\end{array}$ & $\begin{array}{l}a=4.445 \\
c=8.908\end{array}$ & 2 & 12.38 & & $\mathrm{P} 4 / \mathrm{nmm}$ & $\begin{array}{l}\text { C38-type } \\
\text { structure }\end{array}$ \\
\hline
\end{tabular}

\section{References}

(1) Ahmann, D. H., and Baldwin, R. R., "The Uranium-Bismuth System", CT-2961 (November 12, 1945).

(2) Teite1, R. J., "Uranium-Bismuth System", Trans, A.I. M.E., 209, 131-6 (1957).

(3) Ferro, Ricardo, "Alloys of Uranium With Bismuth II", Atti accad. nazl. Lincei. Rend. , Classe sci. fis., mat. e nat., 14, 89-94 (1953).

(4) Brewer, L. , Edwards, R. K. , and Templeton, D. H., "The Crystal Structure of UBi", AECU -653 (November I5, 1949).

(5) Ferro, Ricardo, "Alloys of Uranium With Bismuth", Atti, accad. nazl. Lincei. Rend, Classe sci. fis., mat. e nat., 13, 401-5 (1952).

(6) Greenwood, G. W., "The Solubilities of Uranium and Thorium in Liquid Bismuth", A.E.R.E. M/R 2234 (June, 1957).

(7) Cotteril1, P., United Kingdom, unpublished information (April, 1957).

(8) Bareis, D. W., "Liquid Reactor Fuels: Bismuth-Uranium System", BNL-75 (September 15, 1950).

\section{URANIUM-BORON}

Although the diagram has not been completed some data are available on the general characteristics of the uranium-boron system. The system contains three intermetallic compounds: $\mathrm{UB}_{2}, \mathrm{UB}_{4}$, and $\mathrm{UB}_{12}{ }^{(1)}$. The portion of the diagram between pure uranium and $\mathrm{UB}_{2}$ has been studied(2) and determined to be of simple eutectic form with the eutectic temperature between 1120 and $1128 \mathrm{C}$. The melting point of UB 2 is $2440 \mathrm{C}$. UB 4 exhibits a higher melting temperature $(3)$ and forms a eutectic with UB 2 well above $1565 \mathrm{C}$.

The compound UB 12 is reported to be too unstable for refractory use( 3 ) and it does not exist at as such high temperatures as do $\mathrm{UB}_{2}$ and $\mathrm{UB}_{4}$. 


\section{Crystallography}

The crystallography of $\mathrm{UB}_{2}, \mathrm{UB}_{4}$, and $\mathrm{UB}_{12}$ is summarized below. The lattice constants for UB 2 are reported by Daane and Baenziger(1). Similar results are reported by Brewer(3), but the lattice constants are given as $a=3.136 \pm 0.006 \mathrm{~A}$ and $\mathrm{c}=3.988 \pm 0.008 \mathrm{~A}$.

The lattice constants of UB4 are taken from the work of Brewer(3). Similar but slightly lower values are reported by Bertaut(4). Both Bertaut(4) and Zalkin(5) report the space group of $\mathrm{UB}_{4}$ to be $\mathrm{P} 4 / \mathrm{mbm}$.

The data for $U B_{12}$ are the work of Andrieux and Blum(6). Additional discussion of the uranium borides can be found in The Chemistry of Uranium( 7 ).

\begin{tabular}{|c|c|c|c|c|c|c|c|}
\hline \multirow[b]{2}{*}{ Phase } & \multicolumn{3}{|c|}{ Unit Cell } & \multirow{2}{*}{\multicolumn{2}{|c|}{$\begin{array}{r}\text { Density, } \\
\mathrm{g} / \mathrm{cm}^{3} \\
\end{array}$}} & \multirow[b]{2}{*}{$\begin{array}{l}\text { Space } \\
\text { Group }\end{array}$} & \multirow[b]{2}{*}{ Remarks } \\
\hline & Type & $\begin{array}{c}\text { Dimensions, } \\
\mathrm{A}\end{array}$ & $\begin{array}{c}\begin{array}{c}\text { Number } \\
\text { of } \\
\text { Molecules } \\
\end{array} \\
\end{array}$ & & & & \\
\hline $\mathrm{UB}_{2}$ & $\begin{array}{l}\text { Hexag- } \\
\text { onal }\end{array}$ & $\begin{array}{l}a=3.12 \\
c=3.96\end{array}$ & 1 & 12.82 & 12.8 & & $\begin{array}{l}\text { Axial ratio suggests it } \\
\text { may be isomorphous } \\
\text { with } \mathrm{AlB}_{2}\end{array}$ \\
\hline $\mathrm{UB}_{4}$ & $\begin{array}{l}\text { Tetrag- } \\
\text { onal }\end{array}$ & $\begin{array}{l}a=7.075 \div 0.004 \\
c=3.979 \pm 0.002\end{array}$ & 4 & & & $\mathrm{P} 4 / \mathrm{mbm}$ & $\begin{array}{l}\text { Isomorphous with } \\
\mathrm{ThB}_{4} \text { and } \mathrm{CeB}_{4}\end{array}$ \\
\hline $\mathrm{UB}_{12}$ & $\mathrm{Fcc}$ & $a=7.473$ & 4 & 5.825 & & $\mathrm{Fm} 3 \mathrm{~m}$ & \\
\hline
\end{tabular}

\section{References}

(1) Daane, Adrian, and Baenziger, N. C., unpublished information (July 18, 1949).

(2) Howlett, B. W., and Marriott, B., Associated Electrical Industries Research Laboratory, United Kingdom, unpublished information (March, 1957).

(3) Brewer, L., Sawyer, D. L., Templeton, D. H., and Dauben, C. H., "The Borides of Uranium and Thorium" (AECD-2823), J. Chem. Phys., 18, 391 (1950).

(4) Bertaut, F., and Blum, P., "The Structure of the Borides of Uranium", Compt. rend., $229,666-667$ (1949).

(5) Zalkin, A., and Templeton, D. H., "The Crystal Structure of CeB4, ThB 4, and UB 4", Acta Cryst. , 6, 269-272 (1953); J. Chem. Phys., 18, 391 (1950).

(6) Andrieux, J. L., and Blum, P., Compt. rend., 229, 210 (1949).

(7) Katz, J. J., and Rabinowitch, Eugene, The Chemistry of Uranium, Part I, McGrawHill Book Company, Inc., New York (1951), p 214.

\section{URANIUM-CALCIUM}

There are very few data on the uranium-calcium system. However, in attempts to prepare calcium alloys, Ahmann(l) found no reaction between uranium and calcium after as much as $24 \mathrm{hr}$ at $800 \mathrm{C}$.

Crystallography

There are no compounds in the uranium-calcium system.

\section{Reference}

(1) Ahmann, D. H., "Note on Attempts to Prepare Magnesium and Calcium Alloys of Uranium", CT-2959 (December 5, 1945). 


\section{URANIUM-CARBON}

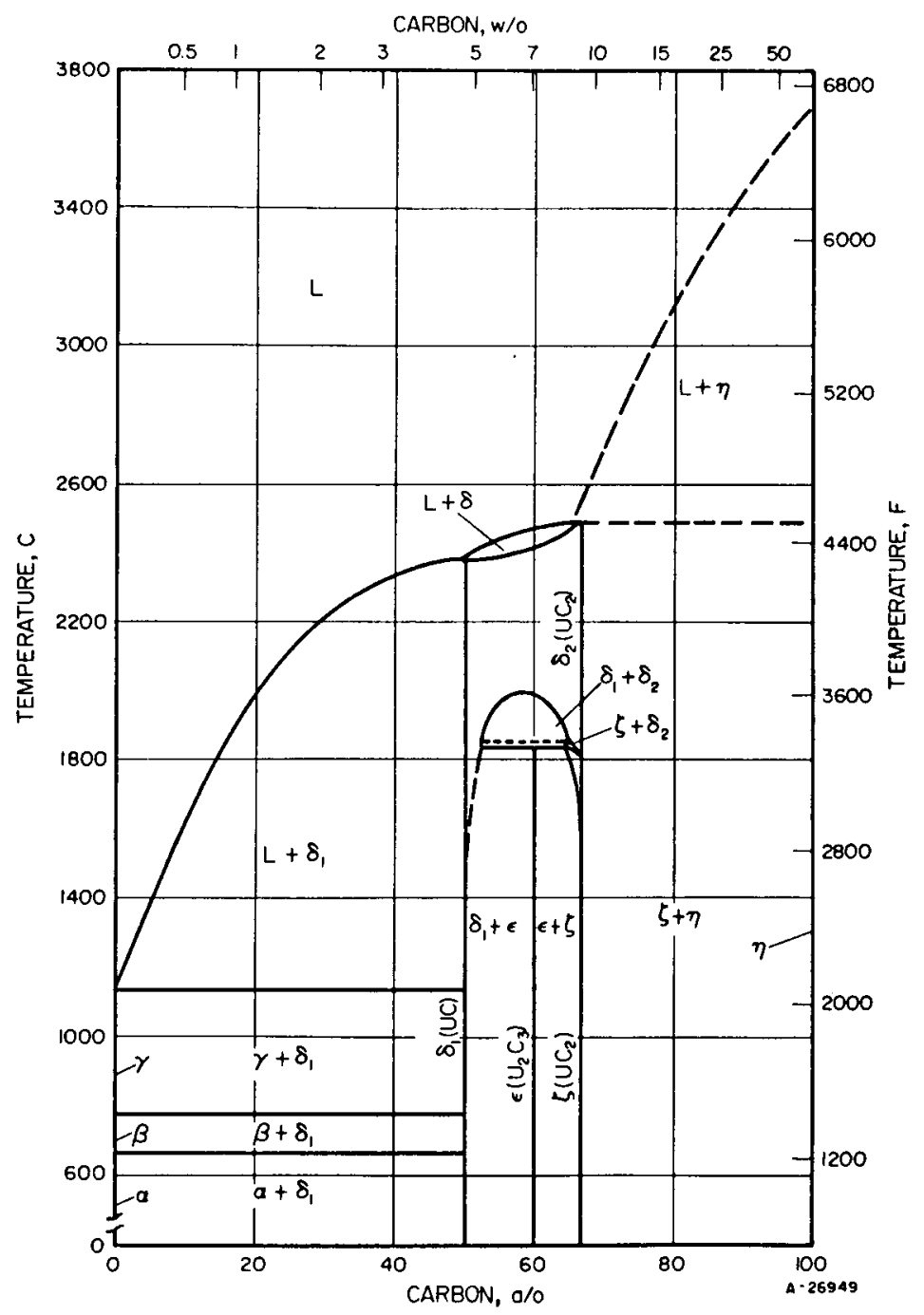

The Constitutional Diagram

The constitutional diagram for uranium-carbon shown in the accompanying figure(1) has been revised to show the allotropic transformation of $\mathrm{UC}_{2}$ from tetragonal to face-centered cubic at $1820 \pm 20 \mathrm{C}(2)$. Two additional compounds, $\mathrm{UC}$ and $\mathrm{U}_{2} \mathrm{C}_{3}$, are found in the system. Early investigators (3) did not discover $\mathrm{U}_{2} \mathrm{C}_{3}$ by $\mathrm{X}$-ray examination but had indirect indications that $\mathrm{U}_{2} \mathrm{C}_{3}$ might exist at high temperatures and decompose during cooling. Later, Mallett and co-workers $(4)$ obtained the sesquicarbide by heating the proper uranium-carbon composition in the range 1250 to $1800 \mathrm{C}$ and then subjecting it to a slight stress. The requirement of residual stress for the formation of $\mathrm{U}_{2} \mathrm{C}_{3}$ has since been confirmed (2). The sesquicarbide formed by this technique is stable from room temperature to $1840 \pm 20 \mathrm{C}$.

$\mathrm{UC}$ and $\mathrm{UC}_{2}$ are reported to be mutually soluble in the region above the sesquicarbide(l,2). Solubilities of carbon in gamma uranium have been reported by Blumenthal(5) as follows:

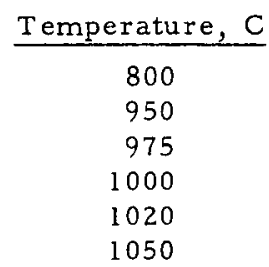

\begin{tabular}{r} 
Solubility, ppm \\
\hline 65 \\
70 \\
80 \\
90 \\
110 \\
115
\end{tabular}




\section{Crystallography}

The crystallography of the uranium carbides is summarized in the tabulation below. The data for UC are from Rundle ${ }^{(6)}$. Wilson ${ }^{(2)}$ gives values of 4.9614 and $4.9597 \pm 0.0005 \mathrm{~A}$ for UC at room temperature, and Litz $(7)$ reports a value of a $=4.955 \mathrm{~A}$. The data for $\mathrm{U}_{2} \mathrm{C}_{3}$ are from Mallett (4); a value of $0.8070 \pm 0.0005 \mathrm{~A}$ is given by Wilson $(2)$. The data for the tetragonal and face-centered cubic forms of $\mathrm{UC}_{2}$ are from Wilson. Similar data are reported by Rundle ${ }^{(6)}$, who reports values of $a=3.524$ and $c=5.999$, and by Litz ${ }^{(7)}$ who gives lattice constants of $\mathrm{a}=3.54$ and $\mathrm{c}=5.99 \mathrm{~A}$.

Discussion of this system can also be found in The Chemistry of Uranium ${ }^{(8)}$.

\begin{tabular}{|c|c|c|c|c|c|c|c|}
\hline \multirow[b]{3}{*}{ Phase } & \multicolumn{3}{|c|}{ Unit Cell } & \multirow{2}{*}{\multicolumn{2}{|c|}{$\begin{array}{c}\text { Density } \\
\text { g/ } / \mathrm{cm}^{3}\end{array}$}} & \multirow{3}{*}{$\begin{array}{r}\text { Space } \\
\text { Group } \\
\end{array}$} & \multirow[b]{3}{*}{ Remarks } \\
\hline & \multirow[b]{2}{*}{ Type } & \multirow{2}{*}{$\begin{array}{c}\text { Dimensions, } \\
\mathrm{A} \\
\end{array}$} & \multirow{2}{*}{$\begin{array}{c}\text { Number } \\
\text { of } \\
\text { Molecules } \\
\end{array}$} & & & & \\
\hline & & & & X-Ray & Other & & \\
\hline $\begin{array}{r}\text { Delta } \\
\text { (UC) }\end{array}$ & $\mathrm{Fcc}$ & $a=4.961$ & 4 & 13.63 & & & $\begin{array}{l}\text { NaCl-type } \\
\text { structure }\end{array}$ \\
\hline $\begin{array}{l}\text { Epsilon } \\
\qquad\left(\mathrm{U}_{2} \mathrm{C}_{3}\right)\end{array}$ & Cubic & $a=8.088$ & 8 & 12.88 & & $I 43 \mathrm{~d}$ & \\
\hline $\begin{array}{l}\text { Zeta } \\
\quad\left(\mathrm{UC}_{2}\right)\end{array}$ & $\begin{array}{l}\text { Bc tetrag- } \\
\text { onal }\end{array}$ & $\begin{array}{l}a=3.516 \\
c=5.972\end{array}$ & 2 & 11.68 & & $14 / \mathrm{mmm}$ & $\begin{array}{r}\mathrm{CaC}_{2} \text {-type } \\
\text { structure }\end{array}$ \\
\hline $\begin{array}{c}\text { Delta }_{2} \\
\left(\mathrm{UC}_{2}\right)\end{array}$ & $\mathrm{Fcc}$ & $a=5.472$ & 4 & & & & $\begin{array}{l}\mathrm{CaF}_{2} \text {-type } \\
\text { structure; } \\
\text { data for } \\
1820 \mathrm{C}\end{array}$ \\
\hline
\end{tabular}

References

(1) Mallett, M. W., Gerds, A. F., and Nelson, H. R., "The Uranium-Carbon System", Trans. Electrochem. Soc., 99, 197-204 (1952).

(2) Wilson, W. B., private communication (1957).

(3) Wilhelm, H. A., Chiotti, P., Snow, A. I., and Daane, A. H., "The Carbides of Uranium and Thorium", J. Chem. Soc. (Supplementary Issue 2), 318-321 (1949).

(4) Mallett, M. W., Gerds, A. F., and Vaughan, D. A., "Uranium Sesquicarbide" (AECD3060); Trans. Electrochem. Soc., 98, 505-509 (1951).

(5) Blumentha1, B., "Uranium Alloy Newsletter", WASH-296, 10 (March, 1956).

(6) Rundle, R. E., Baenziger, N. C., Wilson, A. S., and McDonald, R. A., "The Structures of the Carbides, Nitrides, and Oxides of Uranium", J. Am. Chem. Soc., 70, 99-05 (1948).

(7) Litz, L., Garrett, A. B., and Croxton, F. C., "Preparation and Structure of the Carbides of Uranium", J. Am. Chem. Soc., 70, 1718 (1948).

(8) Katz, J. J., and Rabinowitch, Eugene, The Chemistry of Uranium, Part I, McGrawHill Book Company, Inc. (1951), p 217.

\section{URANIUM-CERIUM}

Only limited data exist for the uranium-cerium system.

Uranium and cerium are only partially miscible in the liquid state. $(1,2,3,4)$ There is evidence of a eutectic at the uranium end of the system, perhaps at about $1000 \mathrm{C} .(2,3)$ The solubility of cerium in liquid uranium is reported to increase from $1.0 \mathrm{w} / \mathrm{o}$ at $1150 \mathrm{C}$ to 1.5 $\mathrm{w} / \mathrm{o}$ at $1250 \mathrm{C}$, while the solubility of uranium in cerium increases from $1.3 \mathrm{w} / \mathrm{o}$ at $1000 \mathrm{C}$ to $3.5 \mathrm{w} / 0$ at $1250 \mathrm{C.}(4)$ 
Crystallography

There are no compounds in the uranium-cerium system.

References

(1) National Physical Labóratory, United Kingdom, unpublished information (May, 1949).

(2) Neher, M. , Cullity, B. D., and Kauffman, A. R., unpublished information (January, 1945).

(3) Greninger, A. B., and Foote, F., unpublished information (May, 1945).

(4) Wilhelm, H. A., Nuclear Fuels Newsletter, WASH-704 (December, 1952). Classified.

\section{URANIUM-CHROMIUM}

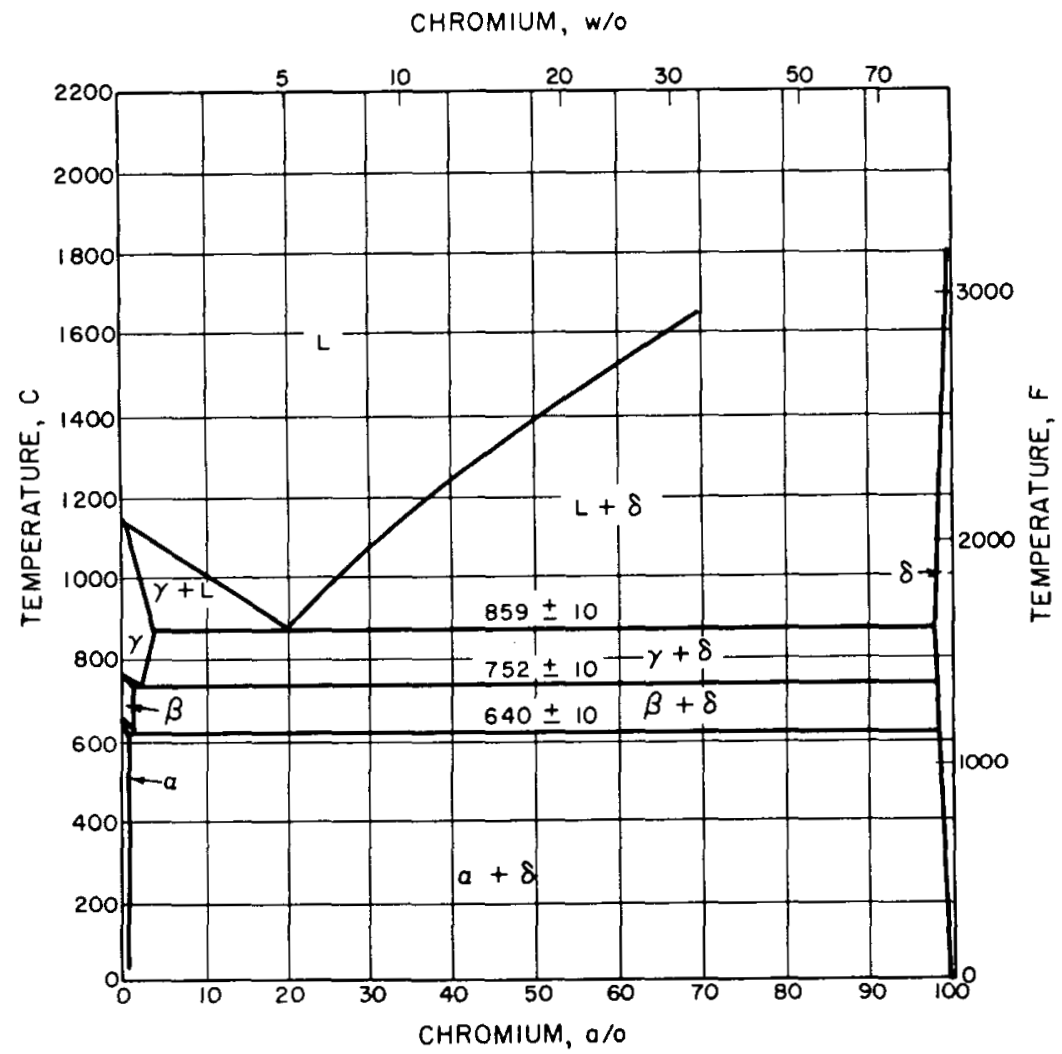

\section{The Constitutional Diagram}

Chromium is one of the few elements which forms a eutectic with uranium, without intervening intermetallic compounds. The diagram which is shown here is based largely on the work of Daane and Wilson(1), who studied the system by X-ray, thermal, and metallographic techniques. The eutectoid isotherms were revised by Saller, on the basis of both thermal and dilatometric measurements. The eutectic composition appears to be slightly less than 20 a/o chromium, or about 19.4 a/o chromium(2). This composition was determined by using a series of low-carbon cast samples. The work of Mott and Haines (3) confirms the diagram presented here.

The solubility of uranium in chromium is slight, and the solubility of chromium in uranium is limited(1). In the gamma uranium, the solubility of chomium is variously re- 
ported to be $4 \mathrm{a} / \mathrm{o}(1)$ and greater than $5 \mathrm{a} / \mathrm{o}(3)$. On the basis of the behavior of beta-treated alloys during isothermal transformation in the alpha region(4), the solubility in beta-uranium is estimated to be about 1.5 a/o chromium. The solubility of chromium in alpha-uranium is somewhat less than in the beta, but is not known $(1,3)$.

Bloom and Grant $(5)$ have reported that an allotropic change occurs in chromium just below its melting point, but this change is not confirmed by McCaldin and Duwez $(6)$. In either case, this portion of the diagram would be relatively unimportant for working with these alloys.

\section{Crystallography}

There is no compound in the uranium-chromium system.

\section{References}

(1) Daane, A. H., and Wilson, A. S., "Uranium-Chromium System", J. Metals, 7, 1219 (1955).

(2) Saller, H. A., Rough, F. A., and Dickerson, R. F., "Preparation and Properties of the Eutectic Uranium-Chromium Alloy", BMI-884 (November, 1953).

(3) Mott, B. W., and Haines, H. R., "A Metallographic Study of the Transformation of Beta, etc." (Appendix I: Note on the Constitution of U-Cr Alloys), AERE M/R 1211 (June 19, 1953).

(4) White, D. W., Knolls Atomic Power Laboratory, unpublished information (1952).

(5) Bloom, D. S., and Grant, N. J., "Chromium-Nickel Phase Diagram", J. Metals, (11), 1009 (1951).

(6) McCaldin, J. A., and Duwez, Pol, "Allotropic Transformations at High Temperature", J. Metals, (5), 619-20 (1954). 


\section{URANIUM-COBALT}

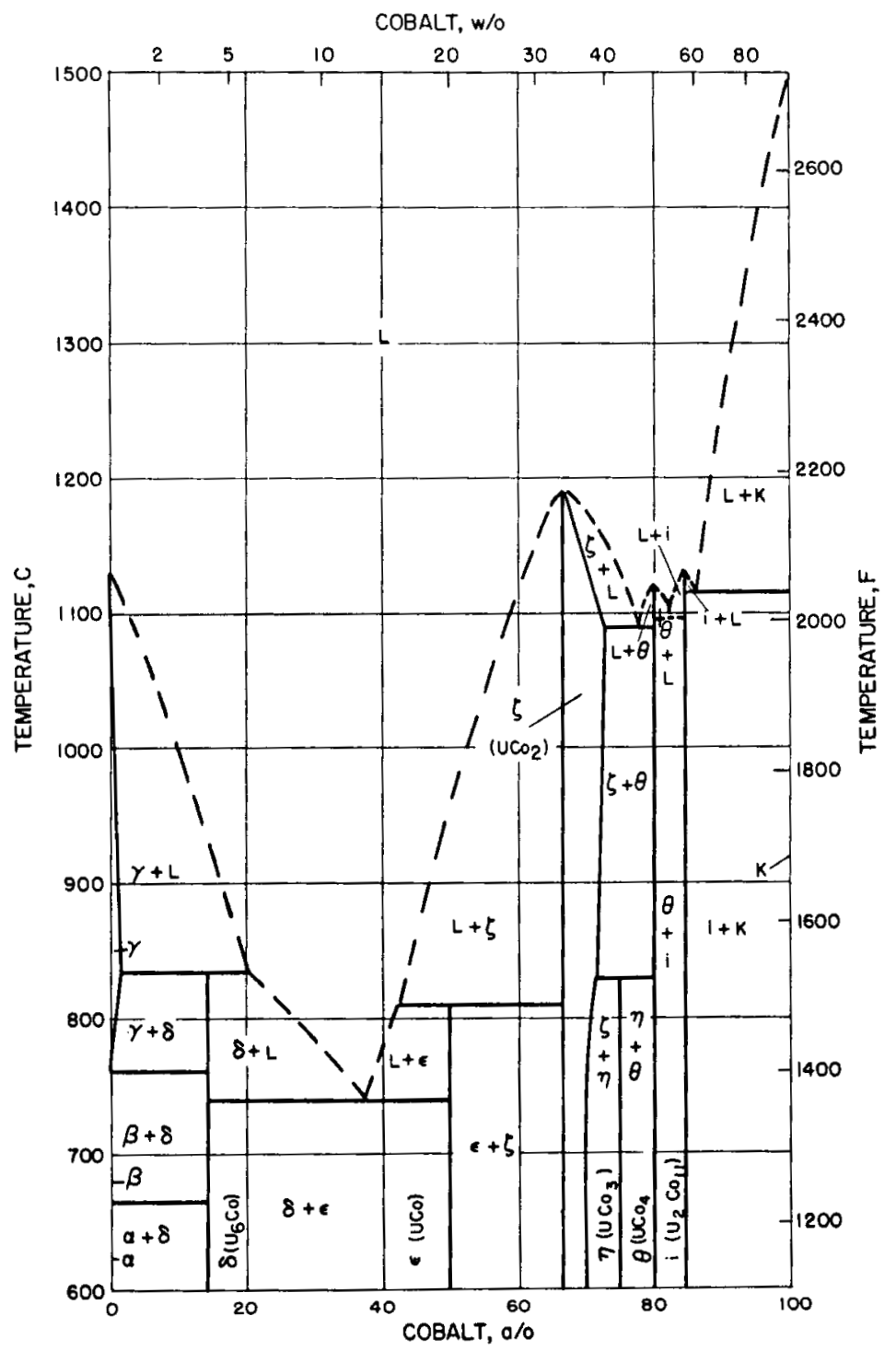

\section{The Constitutional Diagram}

The diagram shown is that of Waldron and Browne ${ }^{(1)}$ and is in agreement with the earlier work of Noyce and Daane(2) except at the cobalt-rich end, where Waldron and Browne report a larger solubility range for $\mathrm{UCo}_{2}$ and three additional compounds with compositions $\mathrm{UCo}_{3}, \mathrm{UCo}_{4}$, and $\mathrm{U}_{2} \mathrm{Co}_{11}$.

\section{Crystallography}

The crystal structures are known for three of the six compounds $(3)$. The compound $\mathrm{U}_{6} \mathrm{Co}$ is isomorphous with $\mathrm{U}_{6} \mathrm{Mn}, \mathrm{U}_{6} \mathrm{Fe}$, and $\mathrm{U}_{6} \mathrm{Ni}$. The observed unit-cell volume for all these phases is nearly equal to the volume calculated by addition of atomic volumes, or about $550 \mathrm{~A}^{3}$. The atomic positions can be described on the basis of space group $14 / \mathrm{mcm}$, although a possible variation from their positions in space groups 142 and $14 \mathrm{c} 2$ has not been eliminated.

The structure of $\mathrm{UCo}_{2}$ has been reported by both Baenziger(3) and Waldron and Browne, the latter claiming a large variation of unit cell size with composition. UCo 2 has the C15, $\mathrm{MgCu}_{2}$ structure and is isomorphous with $\mathrm{UFe}_{2}$ and $\mathrm{UMn}_{2}$ but not with $\mathrm{UNi}_{2}$, which has the $\mathrm{Cl} 4, \mathrm{MgZn}_{2}$ structure. Ternary alloys involving the se phases are reported in the section devoted to ternary alloys. 
Crystal structures have not yet been reported for the remaining phases.

\begin{tabular}{|c|c|c|c|c|c|c|}
\hline \multirow[b]{2}{*}{ Phase } & \multicolumn{3}{|c|}{ Unit Cell } & \multirow[b]{2}{*}{ Density, $\mathrm{g} / \mathrm{cm}^{3}$} & \multirow[b]{2}{*}{$\begin{array}{l}\text { Space } \\
\text { Group } \\
\end{array}$} & \multirow[b]{2}{*}{ Remarks } \\
\hline & Type & $\begin{array}{c}\text { Dimensions, } \\
\mathrm{A}\end{array}$ & $\begin{array}{c}\begin{array}{c}\text { Number } \\
\text { of }\end{array} \\
\text { Molecules } \\
\end{array}$ & & & \\
\hline $\begin{array}{l}\text { Delta } \\
\qquad\left(\mathrm{U}_{6} \mathrm{Co}\right)\end{array}$ & Bc tetragonal & $\begin{array}{r}10.36 \pm 0.02 \\
5.21 \pm 0.02\end{array}$ & 4 & 17.7 & $\begin{array}{l}\mathrm{I} 4 / \mathrm{mcm} \\
\mathrm{I} 42 \text { or } \\
I \overline{4} \mathrm{c}^{2}\end{array}$ & $\begin{array}{l}\text { Isomorphous } \\
\text { with } \mathrm{U}_{6} \mathrm{Mn}, \\
\mathrm{U}_{6} \mathrm{Fe} \text {, and } \\
\mathrm{U}_{6} \mathrm{Mn}\end{array}$ \\
\hline $\begin{array}{l}\text { Epsilon } \\
\text { (UCo) }\end{array}$ & $\mathrm{Bcc}$ & $\begin{array}{c}6.3557 \pm \\
0.0004\end{array}$ & 8 & 15.37 & $\begin{array}{l}\mathrm{I} 43 \mathrm{~m} \text { or } \\
\mathrm{I} 2,3\end{array}$ & \\
\hline $\begin{array}{l}\text { Zeta } \\
\quad\left(\mathrm{UCo}_{2}\right)\end{array}$ & $F \mathrm{Cc}$ & $\begin{array}{c}6.929 \text { to } \\
7.000\end{array}$ & 8 & 13.83 & $\mathrm{Fd} 3 \mathrm{~m}$ & $\begin{array}{l}\mathrm{C} 15, \mathrm{MgCu}_{2} \\
\text { structure; } \\
\text { isomorphous } \\
\text { with } \mathrm{UFe}_{2} \\
\text { and } \mathrm{UMn}_{2}\end{array}$ \\
\hline
\end{tabular}

$\underline{\text { References }}$

(1) Waldron, M. B., and Browne, J. D. , United Kingdom, unpublished information (1956).

(2) Noyce, W. K., and Daane, A. H., "The Uranium-Cobalt System", AECD-2826, (March 1, 1946).

(3) Baenziger, N. C., et al. "Compounds of Uranium With the Transition Metals of the First Long Period" (AECD-2598), Acta Cryst., 3, 34-40 (1950).

\section{URANIUM-COPPER}

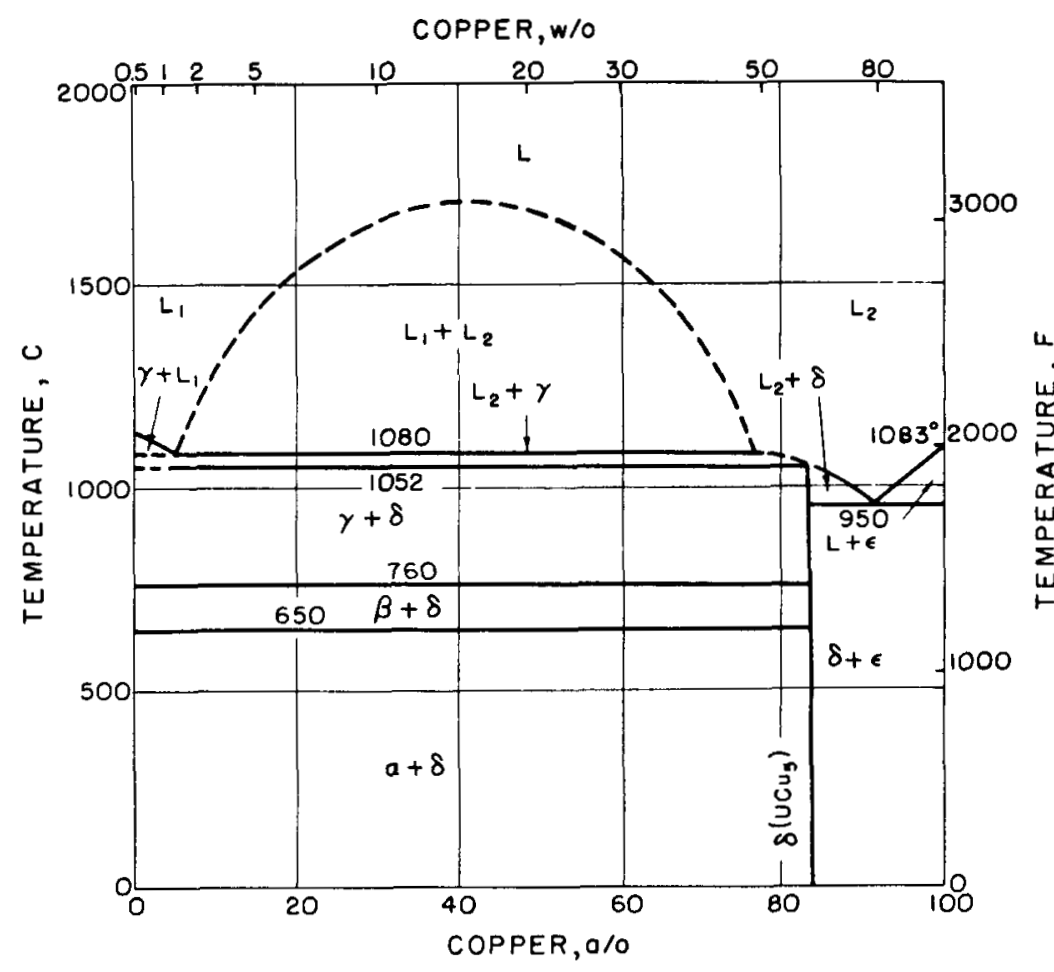




\section{The Constitutional Diagram}

The system uranium-copper has been studied and a diagram has been constructed on the basis of information obtained by X-ray diffraction, thermal analysis, and metallography (1). The diagram is self explanatory. The region of immiscibility above $1080 \mathrm{C}$ is reported to extend from 1,5 to $48 \mathrm{w} / \mathrm{o}$ copper. The immiscibility was found to exist in 5 and $45 \mathrm{w} / 0$ copper alloys at $1550 \mathrm{C}$ and in a $25 \mathrm{w} / \mathrm{o}$ copper alloy at 1850 to $1900 \mathrm{C}(1)$.

Data from the United Kingdom $(2,3)$ indicate that an additional compound, or compounds, may occur in this system. This indication is not supported by the work of Wilhelm and Carlson (1), although a small thermal break was observed at $860 \mathrm{C}$ in the uranium-rich portion of the system. This break conceivably could be related to the presence of an additional compound, although it was considered to be the result of contamination at the time of the study. If an additional compound is present in the system, it is surely in the high-uranium region, since $\mathrm{X}$-ray studies showed that $\mathrm{UCu}_{5}$ and copper exist together in copper-rich alloys (1).

There is evidence of slight solubility of uranium in UCu5. There is no evidence of appreciable solubility of uranium in copper, or of copper in uranium(1).

\section{Crystallography}

The structure of $\mathrm{UCu}_{5}$ has been determined by Baenziger (4). The data on this compound are tabulated below. The dimensions of the face-centered cubic unit cell vary from $7.033 \pm$ 0.002 to $7.038 \pm 0.001 \mathrm{~A}$, indicating a slight solubility of uranium in UCu $\mathrm{U}_{5}$.

Wilhelm and Carlson ${ }^{(1)}$ have reported a lattice constant of $a=7.0208 \pm 0.002 \mathrm{~A}$. The calculated and observed densities are $10.60 \pm 0.02$ and $10.6 \mathrm{~g} / \mathrm{cm}^{3}$, respectively.

\begin{tabular}{|c|c|c|c|c|c|c|c|}
\hline \multirow[b]{3}{*}{ Phase } & \multirow[b]{3}{*}{ Type } & \multicolumn{2}{|l|}{ Unit Cell } & \multirow{2}{*}{\multicolumn{2}{|c|}{$\begin{array}{c}\text { Density, } \\
\mathrm{g} / \mathrm{cm}^{3} \\
\end{array}$}} & \multirow{3}{*}{$\begin{array}{l}\text { Space } \\
\text { Group }\end{array}$} & \multirow[b]{3}{*}{ Remarks } \\
\hline & & \multirow{2}{*}{$\begin{array}{c}\text { Dimensions, } \\
\mathrm{A} \\
\end{array}$} & \multirow{2}{*}{$\begin{array}{c}\text { Number } \\
\text { of } \\
\text { Molecules } \\
\end{array}$} & & & & \\
\hline & & & & X-Ray & Other & & \\
\hline $\begin{array}{l}\text { Delta } \\
\quad\left(\mathrm{UCu}_{5}\right)\end{array}$ & $F C c$ & $\begin{array}{l}7.033 \pm 0.002 \\
\text { to } 7.038 \pm \\
0.001\end{array}$ & 4 & & & $\begin{array}{l}\mathrm{F} \overline{4} 3 \mathrm{~m} \text { or } \\
\quad \mathrm{F} 23\end{array}$ & $\begin{array}{l}\text { Isomorphous with } \\
\mathrm{UNi}_{5}, \mathrm{PdBe}_{5} \text {, } \\
\text { and } \mathrm{AuBe}_{5}\end{array}$ \\
\hline
\end{tabular}

\section{References}

(1) Wilhelm, H. A., and Carlson, O. N., "The Uranium-Manganese and Uranium-Copper Alloy Systems" (AECD-2717), Trans. Am. Soc. Metals, 42, 1311 (1950).

(2) Fulmer Research Institute, United Kingdom, unpublished information (1952-1953).

(3) Swansea University College, United Kingdom, unpublished information (May, 1951).

(4) Baenziger, N. C. , Rundle, R. E., Snow, A. I., and Wilson, A. S. , "Compounds of Uranium With the Transition Metals of the First Long Period" (AECD-2598), Acta Cryst. , $3,34-40(1950)$.

\section{URANIUM-DYSPROSIUM}

Uranium and dysprosium exhibit an immiscibility gap in the liquid state. Solubility of dysprosium in liquid uranium is reported to increase from $0.15 \mathrm{w} / \mathrm{o}$ at $1150 \mathrm{C}$ to $0.2 \mathrm{w} / \mathrm{o}$ at $1250 \mathrm{C}(1)$

Crystallography

Nothing is known concerning the possibility of compounds in this system.

\section{Reference}

(1) Wilhelm, H. A., "Nuclear Fuels Newsletter", WASH-704 (December, 1957). Classified. 


\section{URANIUM-ERBIUM}

Uranium and erbium exhibit an immiscibility gap in the liquid state. Solubility of erbium in liquid uranium is reported to increase from $0.15 \mathrm{w} / \mathrm{o}$ at $1150 \mathrm{C}$ to $0.2 \mathrm{w} / \mathrm{o}$ at 1250 C. (1)

Crystallography

Nothing is known concerning the possibility of compounds in this system.

\section{Reference}

(1) Wilhelm, H. A., "Nuclear Fuels Newsletter", WASH-704 (December, 1957). Classified.

\section{URANIUM-EUROPIUM}

Uranium and europium show little miscibility in the liquid state. The solubility of europium in liquid uranium is reported to be $0.15 \mathrm{w} / \mathrm{o}$ at $1150 \mathrm{C}$ and $0.2 \mathrm{w} / \mathrm{o}$ at $1250 \mathrm{C}$, while uranium solubility in europium is given as $0.5 \mathrm{w} / 0$ at $1000 \mathrm{C}$ and $1.3 \mathrm{w} / 0$ at $1250 \mathrm{C}$. (1)

\section{Crystallography}

Data concerning the possibility of compounds in this system are not available.

\section{$\underline{\text { Reference }}$}

(1) Wilhelm, H. A., "Nuclear Fuels Newsletter", WASH-704 (December, 1957). Classified.

\section{URANIUM-GADOLINIUM}

Uranium and gadolinium exhibit an immiscibility gap in the liquid state. Solubility of gadolinium in liquid uranium is reported to increase from $0.075 \mathrm{w} / \mathrm{o}$ at $1150 \mathrm{C}$ to $0.15 \mathrm{w} / \mathrm{o}$ at 1250 C. (1)

Crystallography

Nothing is known concerning the possibility of compounds in this system.

Reference

(1) Wilhelm, H. A., "Nuclear Fuels Newsletter", WASH-704 (December, 1957). Classified. 


\section{URANIUM-GALLIUM}

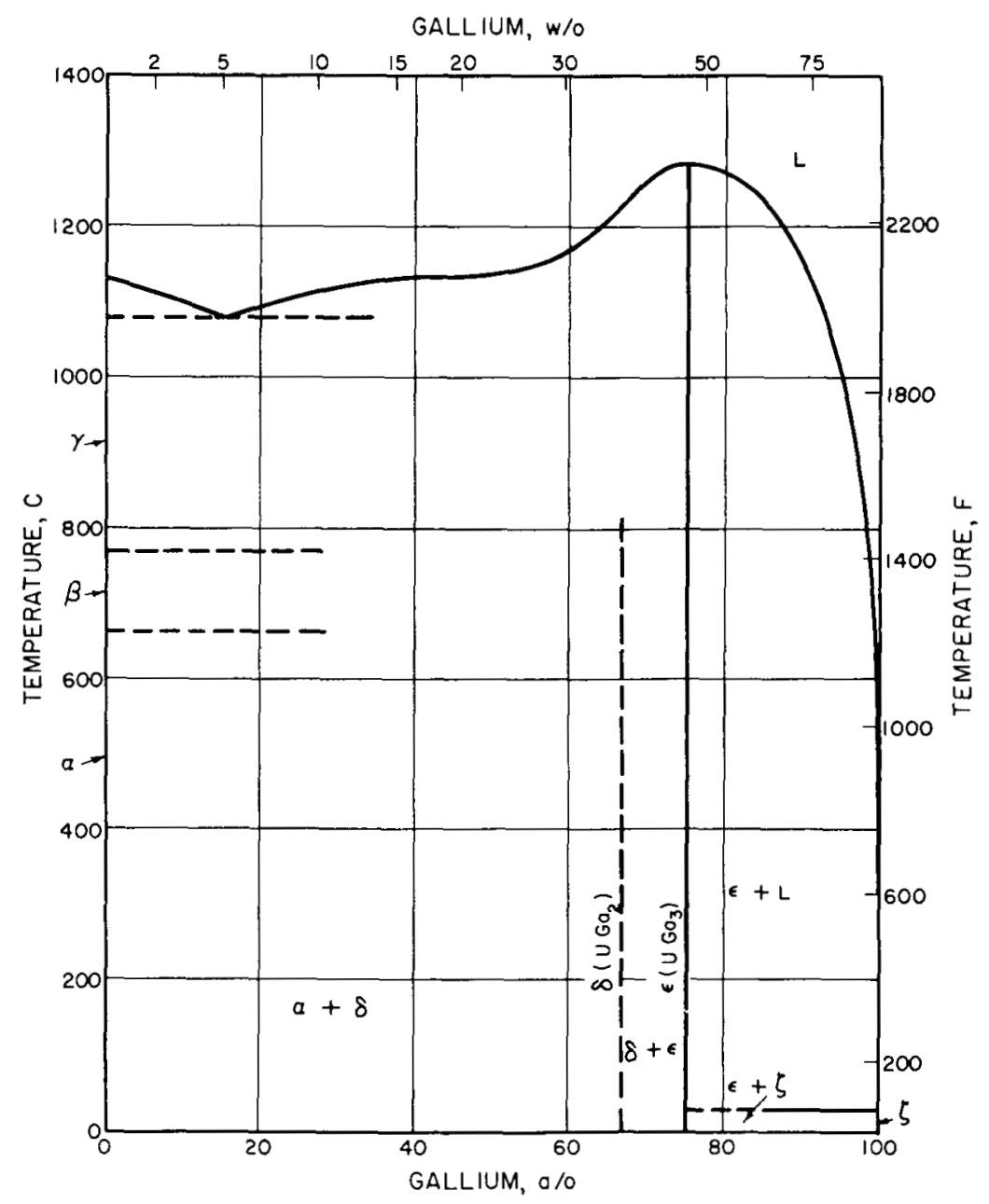

The Constitutional Diagram

The liquidus of the system has been determined by Jaffee. (1) In addition, evidence of two compounds has been reported. Maskrey and Frost (2) reported UGa 3 , while Dempster (3) reported UGa2. Because work in the United Kingdom $(4)$ tends to support the presence of the second compound, it is included with the other data to give a tentative diagram.

Judging from the liquidus and a reported melting point of about $1300 \mathrm{C}$ for $\mathrm{UGa}_{3}{ }^{(4)}$, it seems likely that UGa 3 melts congruently. The compound UGa 2 , if present, may be stable to some lower temperature.

There appears to be a eutectic at the high-uranium end of the system where a dip in the liquidus occurs. Jaffee $\mathrm{e}^{(1)}$ found little solubility of uranium in solid gallium. He found the melting point of gallium virtually unaffected by small additions of uranium. On the other hand, it was reported from the United Kingdom that a eutectic occurs at 14 a/o uranium and about $28 \mathrm{C}(4)$. This report is in serious disagreement with the liquidus as shown. Since complete information is not available, a full evaluation cannot be made.

Jaffee's method for determining the liquidus was rather simple; he determined solubility by feeling with a stirring rod to determine whether uranium was present in the bottom of a crucible of gallium(1). In spite of the simplicity of his method, the resulting data connect nicely with filtration data obtained by Hayes(5) and Wilkinson(6) for temperatures of 700 and $500 \mathrm{C}$ at the gallium end of the system.

The solid solubility of gallium in uranium is reported to be very low(6). 


\section{Crystallography}

The data for UGa3 shown in the tabulation below are from the work of Frost and Maskrey (2). Iandelli has also reported $\mathrm{UGa}_{3}$, giving a lattice constant a $=4.249 \mathrm{~A}^{(7)} \quad \mathrm{UGa}_{2}$ data reported by Dempster ${ }^{(3)}$ were not available.

\begin{tabular}{|c|c|c|c|c|c|c|c|}
\hline \multirow[b]{2}{*}{ Phase } & \multirow[b]{2}{*}{ Type } & Unit Ce11 & $\begin{array}{c}\text { Number } \\
\text { of }\end{array}$ & \multicolumn{2}{|c|}{$\begin{array}{r}\text { Density, } \\
\mathrm{g} / \mathrm{cm}^{3} \\
\end{array}$} & \multirow{2}{*}{$\begin{array}{l}\text { Space } \\
\text { Group }\end{array}$} & \multirow[b]{2}{*}{ Remarks } \\
\hline & & $\mathrm{A}$ & Molecules & X-Ray & Other & & \\
\hline $\mathrm{UGa}_{2}$ & No data & available & & & & & \\
\hline $\mathrm{UGa}_{3}$ & $\begin{array}{r}\text { Simple } \\
\text { cubic }\end{array}$ & $a=4.2475$ & 1 & 9.686 & & $\mathrm{Pm} 3 \mathrm{~m}$ & $\begin{array}{l}\text { L12-type, } \mathrm{AuCu}_{3} \text { ordered } \\
\text { structure; isomorphous } \\
\text { with } \mathrm{UAl}_{3} \mathrm{USn}_{3}, \mathrm{UIn}_{3}, \\
\mathrm{USi}_{3}, \mathrm{UGe}_{3}, \mathrm{UPb}_{3}\end{array}$ \\
\hline
\end{tabular}

References

(1) Jaffee, R. I., Evans, R. M., Fromm, E. O., and Gonser, B. W., "Gallium in Nuclear Reactors; Considerations for Use in Liquid Fuel Rods", BMI-T-20 (January, 1950). Classified.

(2) Maskrey, J. T., and Frost, B.R. T. , "The System Uranium-Lead" (AERE M/R 1027), J. Inst. Metals, (12), 171-80 (1953).

(3) Dempster, A. J., Progress Report, AL-4120, (March, 1948).

(4) Atomic Energy Research Establishment, United Kingdom, unpublished information, (May, 1951).

(5) Hayes, E. E., and Gordon, P., J. Met. and Cer., TID-65, 130-141 (July, 1948). Classified.

(6) Wilkinson, unpublished information (March, 1948).

(7) Iandelli, A., and Ferro, R., Ann, chim. (Rome), 42, 598-606 (1952).

\section{URANIUM-GERMANIUM}

No information is available on the constitution of the uranium-germanium alloys, except that a compound, $\mathrm{UGe}_{3}$, has been identified (1, 2).

\section{Crystallography}

The crystallography of $\mathrm{UGe}_{3}$, as reported by Maskrey and Frost(2), is shown below. Iandelli(1) reports a value of $\mathrm{a}=4.198 \mathrm{~A}$ for $\mathrm{UGe}_{3}$, and reports $\mathrm{UGa}_{3}, \mathrm{UIn}_{3}, \mathrm{UTl}_{3}, \mathrm{USi}_{3}$, and $\mathrm{UPb}_{3}$ to have similar structures.

\begin{tabular}{|c|c|c|c|c|c|}
\hline \multirow[b]{2}{*}{ Phase } & \multicolumn{3}{|c|}{ Unit Cell } & & \\
\hline & Type & $\begin{array}{c}\text { Dimensions, } \\
\mathrm{A} \\
\end{array}$ & $\begin{array}{c}\text { Number } \\
\text { of } \\
\text { Molecules } \\
\end{array}$ & Space Group & Remarks \\
\hline $\mathrm{UGe}_{3}$ & Simple cubic & $a=4.2062$ & 1 & $\mathrm{Pm} 3 \mathrm{~m}$ & $\begin{array}{l}\text { L12-type structure, } \\
\text { isomorphous with } \\
\mathrm{UAl}_{3}, \mathrm{USn}_{3}, \mathrm{USi}_{3}, \\
\mathrm{UGa}_{3}, \mathrm{UIn}_{3}, \mathrm{UPb}_{3}\end{array}$ \\
\hline
\end{tabular}




\section{$\underline{\text { References }}$}

(1) Iandelli, Aldo, and Ferro, Ricardo, Ann. chim. (Rome), 42, 598-606 (1952).

(2) Maskrey, J. T., and Frost, B. R. T. , "The System Uranium-Lead" (AERE M/R 1027), J. Inst. Metals, 811, 171-180 (December, 1953).

\section{URANIUM -GOLD}

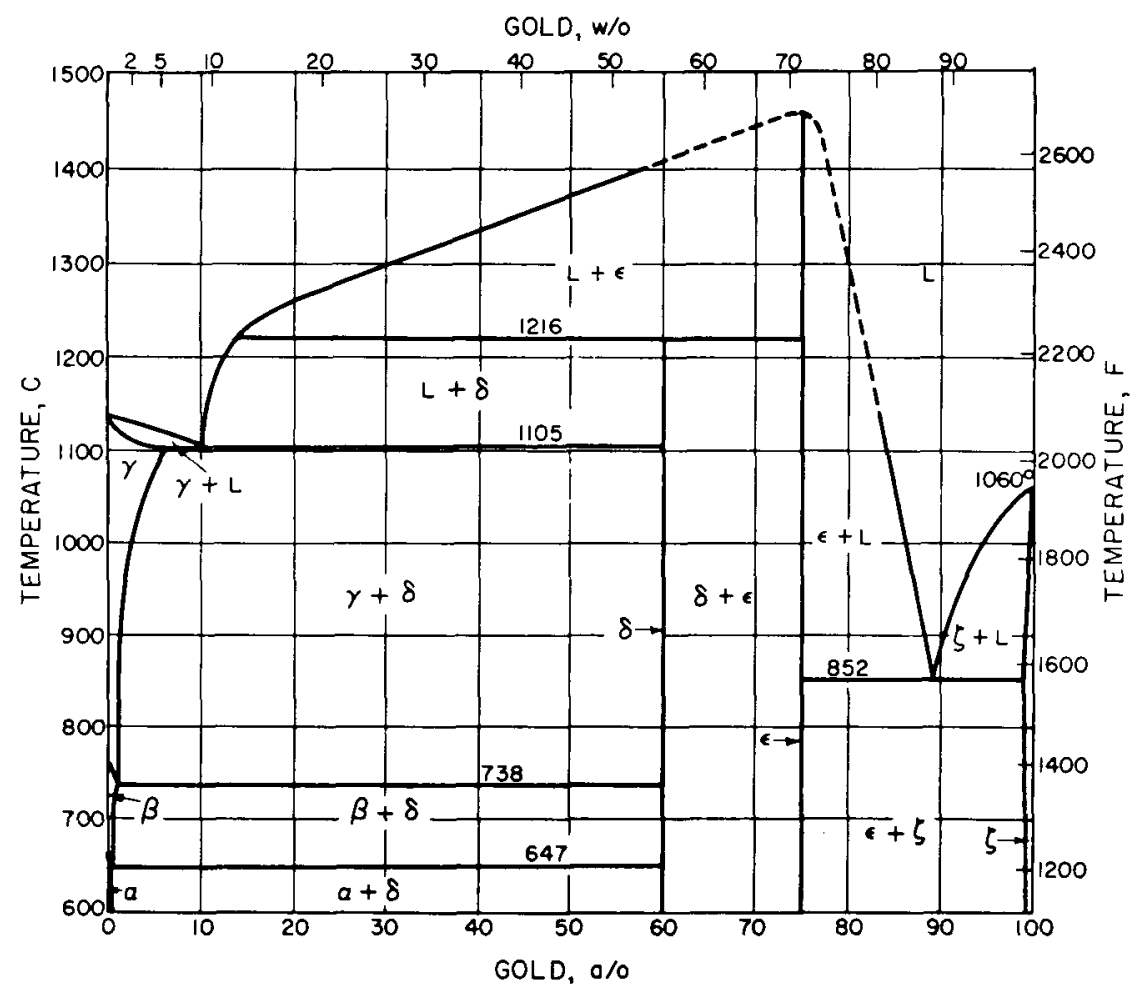

The Constitutional Diagram

The uranium-gold system has been studied by Buzzard(1). The diagram shown was constructed from data obtained by thermal, microscopic, and X-ray analyses.

The uranium-rich eutectic is reported to occur at $1105 \mathrm{C}$ and $10.5 \mathrm{a} / 0$ gold. The goldrich eutectic is reported to occur at 87.5 a/o gold and $852 \mathrm{C}$. (1)

Two compounds were identified by Buzzard, although the structures have not been determined. The compounds appear to be delta $\left(\mathrm{U}_{2} \mathrm{Au}_{3}\right)$ and epsilon $\left(\mathrm{UAu}_{3}\right)$. (1)

The solubility of uranium in gold appears to be between 0.2 and 0.3 a $/ 0$ at $852 \mathrm{C}$, while the solubility of gold in uranium is approximately 6 a/o at $1105 \mathrm{C}$. (1)

Additions of gold lower the transformation temperatures of uranium to 738 and $647 \mathrm{C}$, as shown in the diagram(1).

Data from the United Kingdom do not agree well with this diagram. The National Physical Laboratory reports that as many as six compounds may be present in the system. (2) The completeness of the diagram by Buzzard and the apparent agreement of data obtained by $\mathrm{X}$-ray diffraction, thermal analysis, and metallographic examination lend strong support to the diagram shown.

Crystallography

No information is available on the crystal structure of the compounds in the uraniumgold system. 
(1) Buzzard, R. W. , and Park, J. J., "The Gold-Uranium System", J. Nat1. Bur. Standards, 53, 291 (1954).

(2) National Physical Laboratory, "Note on Some Alloys of Gold and Uranium", AERE X/M 100 (1952).

\section{URANIUM-HOLMIUM}

Uranium and holmium exhibit an immiscibility gap in the liquid state. Solubility of holmium in liquid uranium is reported to increase from $0.025 \mathrm{w} / \mathrm{o}$ at $1150 \mathrm{C}$ to $0.075 \mathrm{w} / \mathrm{o}$ at $1250 \mathrm{C} .(1)$

\section{Crystallography}

Nothing is known concerning the possibility of compounds in this system.

\section{Reference}

(1) Wilhelm, H. A., "Nuclear Fuels Newsletter", WASH-704 (December, 1957). Classified.

\section{URANIUM-HYDROGEN}
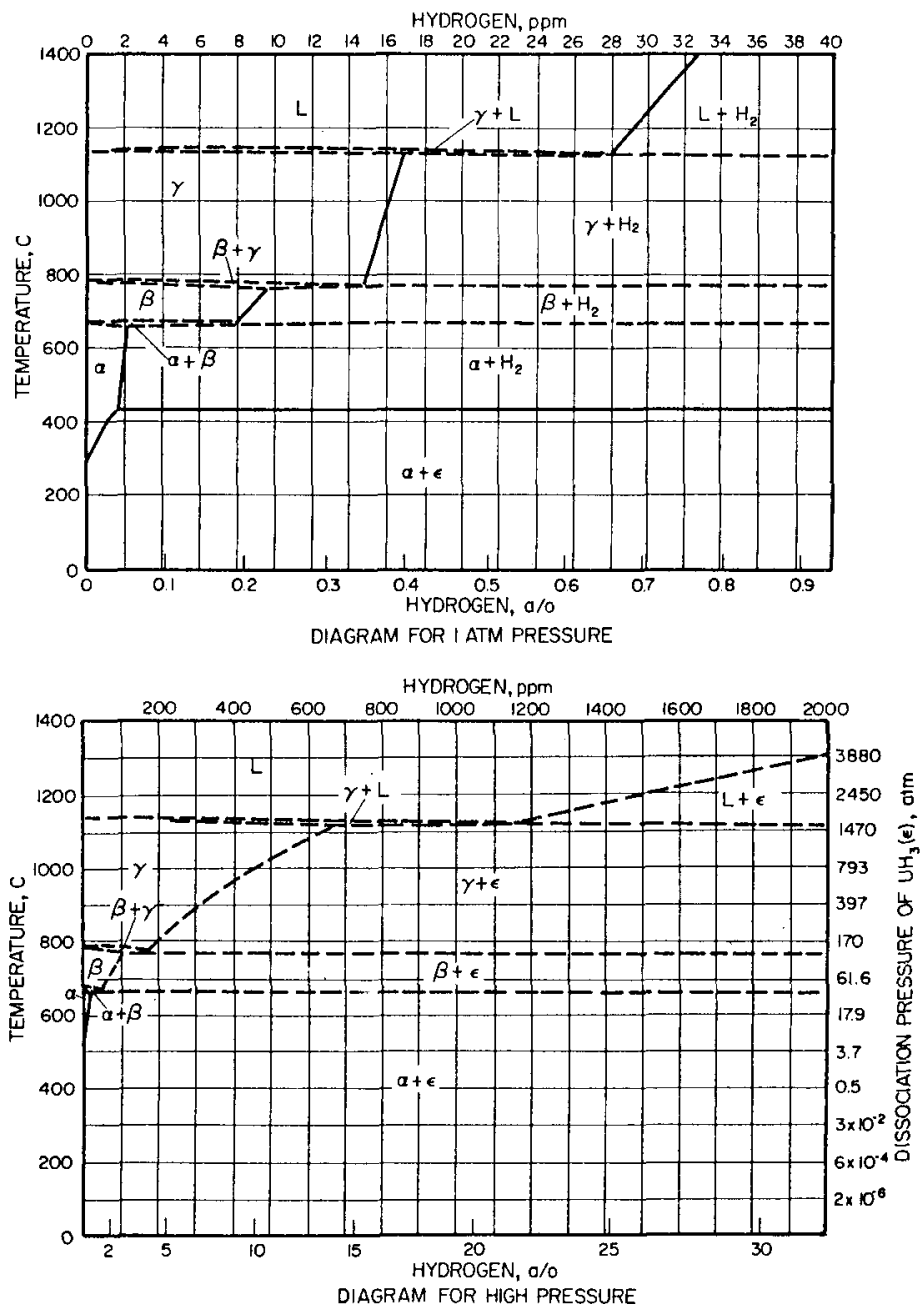
The Constitutional Diagram

The uranium-hydrogen system has received considerable study. Diagrams illustrating the solubility of hydrogen in uranium at 1 -atm pressure and at high pressure have been determined and are shown. (1) Work done since the diagrams were developed has shown that the diagrams are useful; the data are reproducible by the original techniques.

The data were determined by an absorption technique. In this process a sample of uranium rod, dry abraded under argon, is introduced into a gasometric apparatus which is evacuated and then filled with a measured amount of hydrogen. The amount of hydrogen absorbed is calculated from pressure changes in a known volume. The precision of the method is $\pm 0.2 \mathrm{ppm}$ for a 25 -g sample ${ }^{(1)}$.

Mattraw(2) reports a solubility of $3.0 \mathrm{ppm}$ at $295 \mathrm{C}$ and $100-\mu$ pressure. These data disagree with those of Mallett $(1)$ by a factor of 250 . However, it is probable that Mattraw had not observed true interstitial solution of hydrogen, but rather chemisorption on the surface of his finely divided sample. Samples of small surface-to-mass ratio do not show the anomalous high hydrogen pickup. (1)

Many people have contributed to the present knowledge of $\mathrm{UH}_{3}$, the only hydride in this system. It has been shown that $\mathrm{UH}_{3}$ exists in two crystallographic forms. (3, 4) Delta $\mathrm{UH}_{3}$ (called "alpha" $\mathrm{UH}_{3}$ by Mulford), the more recently discovered form, has been produced by reacting uranium powder with hydrogen gas at 25 to minus $80 \mathrm{C}(3)$, by reacting massive uranium with hydrogen gas at minus $40 \mathrm{C}$, and by electrolysis of a solution of $\mathrm{HClO}_{4}$ or $\mathrm{Na}_{2} \mathrm{CO}_{3}$, where uranium is used as the cathode (4). Mulford suggests that delta is metastable. The yield of delta increases as the temperature of formation is decreased. (3)

Once formed, delta does not decompose during annealing at $100 \mathrm{C}$ but does decompose at $250 \mathrm{C}$. No attempt was made to show the delta phase in the diagram because epsilon ("beta" $\mathrm{UH}_{3}$ ) is the phase commonly observed.

\section{Crystallography}

Uranium hydride has been shown to exist in two forms. Data for both delta and epsilon are given in the tabulation along with data for epsilon ("beta") $\mathrm{UD}_{3}$.

The data for delta $\mathrm{UH}_{3}$ are from Mulford(3). Caillat(4) has confirmed this information. He reports that $a=4.161 \pm 0.002 \mathrm{~A}$ and density is $11.1 \mathrm{~g} / \mathrm{cm}^{3}$.

The data for epsilon $\mathrm{UH}_{3}$ and epsilon $\mathrm{UD}_{3}$ are from Rundle. $(5,6)$ These compounds were studied by $X$-ray, although the structure was resolved through neutron-diffraction studies of epsilon $\mathrm{UD}_{3}$. The epsilon $\mathrm{UH}_{3}$ reported by Rundle was prepared under a pressure of 1800 psi at 500 to $600 \mathrm{C}$. (6) Hydride prepared at lower pressures yielded lattice constants of $a=6.32 \pm 0.001 \mathrm{~A}$. Slightly higher values were obtained in earlier work $(7,8)$.

The hydrogen atoms in epsilon $\mathrm{UH}_{3}$ are reported to lie in distorted tetrahedra, equi distant from four uranium atoms with uranium-hydrogen distances of $2.32 \mathrm{~A}$. There are two types of structures, each with 12 nearest hydrogen atoms at this distance. The proposed space group is $\mathrm{Pm} 3 \mathrm{n}$, with parameters for $24(\mathrm{k})$ of $\mathrm{y}=0.155 \pm 0.02$ and $\mathrm{Z}=0.31 \pm 0.02$. These values are sufficiently close to $\mathrm{y}=0.156$ and $\mathrm{Z}=0.313$ to put each hydrogen atom equidistant from four uranium atoms. The structure gives satisfactory agreement between calculated and observed intensities. ${ }^{(5)}$

The structure of epsilon $\mathrm{UH}_{3}$ is unique and is not entirely understood, but it is reported that no metallic uranium-uranium bonds of importance are present in the structure. The hydride is assumed to be held together by uranium-hydrogen interactions. Rundle suggests that these interactions may be described in terms of delocalized covalent bonds. (6)

The work of Gibb(9) may be of general interest. 


\begin{tabular}{|c|c|c|c|c|c|c|c|}
\hline \multirow[b]{3}{*}{ Phase } & \multicolumn{3}{|c|}{ Unit Cell } & & & \multirow{3}{*}{$\begin{array}{l}\text { Space } \\
\text { Group }\end{array}$} & \multirow[b]{3}{*}{ Remarks } \\
\hline & \multirow[b]{2}{*}{ Type } & \multirow{2}{*}{$\begin{array}{c}\text { Dimensions, } \\
\text { A } \\
\end{array}$} & \multirow{2}{*}{$\begin{array}{c}\begin{array}{c}\text { Number } \\
\text { of } \\
\text { Molecules }\end{array} \\
\end{array}$} & \multicolumn{2}{|c|}{$\begin{array}{c}\text { Density, } \\
\mathrm{g} / \mathrm{cm}^{3} \\
\end{array}$} & & \\
\hline & & & & X-Ray & Other & & \\
\hline $\begin{array}{l}\text { Delta } \\
\text { ("alpha") } \mathrm{UH}_{3}\end{array}$ & Cubic & $\begin{aligned} a= & 4.160 \pm \\
& 0.001\end{aligned}$ & 2 & & & $\operatorname{Pm} 3 n$ & \\
\hline $\begin{array}{l}\text { Epsilon } \\
\text { ('beta") } \mathrm{UH}_{3}\end{array}$ & Cubic & $\begin{aligned} a= & 6.6310 \pm \\
& 0.0008\end{aligned}$ & 8 & 10.92 & 10.95 & Pm3n & \\
\hline $\begin{array}{l}\text { Epsilon } \\
\text { ("beta") UD } 3\end{array}$ & Cubic & $\begin{aligned} a= & 6.620 \pm \\
& 0.002\end{aligned}$ & 8 & 11.11 & & $\operatorname{Pm} 3 n$ & \\
\hline
\end{tabular}

\section{$\underline{\text { References }}$}

(1) Mallett, M. W., and Trzeciak, M. J., "Hydrogen Uranium Relationships", Trans. ASM, 50 (1958).

(2) Mattraw, H. C., J. Phys. Chem., 59, 93 (1955).

(3) Mulford, R.N.R., Ellinger, F. H., and Zachariasen, W. H. (AECU-2700), J. Am. Chem. Soc., 76, $297-298(1954)$.

(4) Caillat, R., Coriou, H., and Perio, P., "A New Form of the Hydride of Uranium", Compt, rend., 237, 812-13 (October 12, 1953).

(5) Rundle, R. E., "The Hydrogen Positions in Uranium Hydride by Neutron Diffraction", (AECD-3111), J. Am. Chem. Soc, , 73, 4172-4 (1951).

(6) Rundle, R. E., "The Structure of Uranium Hydride and Deuteride", J. Am. Chem. Soc., $\underline{69}(7), 1719-23(1947)$.

(7) Katz, J. J., and Rabinowitch, Eugene, "The Chemistry of Uranium, Part I", 180-213 (1951).

(8) Zachariasen, W. H., unpublished information (1943).

(9) Gibb, Thomas, Jr., et al., "Metal-Hydrogen Systems III. The Uranium-Hydrogen System", J. Am. Chem. Soc., 7프 (12), 6203-07 (1952).

\section{URANIUM-INDIUM}

A compound, $\operatorname{UIn}_{3}$, has been identified. $(1,2)$ Solubilities of uranium in liquid indium have been reported(3) as given below:

$\begin{array}{llllllll}\text { Temperature, C } & 600 & 650 & 700 & 750 & 800 & 850 & 900 \\ \text { Solubility, w/o } & 0.08 & 0.10 & 0.15 & 0.25 & 0.45 & 0.70 & 1.05\end{array}$

\section{Crystallography}

An intermetallic compound, $\mathrm{UIn}_{3}$, has been reported. $(1,2)$ Data for $\mathrm{UIn}_{3}$ are summarized below (2). Iandelli(1) reports the same structure, but gives a slightly lower lattice constant, $a=4.588 \mathrm{~A}$. He has studied the following $\mathrm{UX}_{3}$-type compounds: $\mathrm{UIn}_{3}, \mathrm{UGa}_{3}, \mathrm{UTI}_{3}$, $\mathrm{USi}_{3}, \mathrm{UGe}_{3}$, and $\mathrm{UPb}_{3}$.

\begin{tabular}{|c|c|c|c|c|c|c|c|}
\hline \multirow[b]{3}{*}{ Phase } & \multicolumn{3}{|c|}{ Unit Cell } & \multirow{2}{*}{\multicolumn{2}{|c|}{$\begin{array}{l}\text { Density, } \\
\text { g/ } \mathrm{cm}^{3}\end{array}$}} & \multirow{3}{*}{$\begin{array}{l}\text { Space } \\
\text { Group }\end{array}$} & \multirow[b]{3}{*}{ Remarks } \\
\hline & \multirow[b]{2}{*}{ Type } & \multirow{2}{*}{$\begin{array}{c}\text { Dimensions, } \\
\mathrm{A} \\
\end{array}$} & \multirow{2}{*}{$\begin{array}{c}\begin{array}{c}\text { Number } \\
\text { of } \\
\text { Molecules } \\
\end{array} \\
\end{array}$} & & & & \\
\hline & & & & X-Ray & Others & & \\
\hline $\mathrm{UIn}_{3}$ & $F c c$ & $a=4.6013$ & 1 & & & $\operatorname{Pm} 3 \mathrm{~m}$ & $\begin{array}{l}\text { LI2-type structure, iso- } \\
\text { morphous with } \mathrm{UGa}_{3} \text {, } \\
\mathrm{USi}_{3}, \mathrm{UGe}_{3}, \mathrm{UPb}_{3}, \\
\mathrm{USn}_{3} \text {, and } \mathrm{UAl}_{3}\end{array}$ \\
\hline
\end{tabular}


References

(1) Iandelli, Aldo, and Ferro, Ricardo, Ann. chim. (Rome), 42, 598-60 (1952).

(2) Maskrey, J. T., and Frost, B.R.T., "The System Uranium-Lead" (AERE M/R-1027), J. Inst. Metals, 81, 171-180 (December, 1953).

(3) Hayes, E. E., and Gordon, P., J. Met. and Cer., TID-65, 130-41 (July, 1948). Classified.

\section{URANIUM-IRIDIUM}

The solubility of iridium in uranium at $890 \mathrm{C}$ is reported(1) to be about 3 a/o. A compound, $\operatorname{UIr}_{2}$, has been identified.

\section{Crystallography}

An intermetallic compound, $\mathrm{UIr}_{2}$, has been reported(2). It has the $\mathrm{Cl} 15, \mathrm{MgCu}_{2}$ structure.

\begin{tabular}{|c|c|c|c|c|c|c|c|}
\hline \multirow[b]{3}{*}{ Phase } & \multicolumn{3}{|c|}{ Unit Cell } & \multirow{2}{*}{\multicolumn{2}{|c|}{$\begin{array}{l}\text { Density, } \\
\mathrm{g} / \mathrm{cm}^{3}\end{array}$}} & \multirow{3}{*}{$\begin{array}{l}\text { Space } \\
\text { Group }\end{array}$} & \multirow[b]{3}{*}{ Remarks } \\
\hline & & Dimensions, & $\begin{array}{c}\text { Number } \\
\text { of }\end{array}$ & & & & \\
\hline & Type & A & Molecules & X-Ray & Other & & \\
\hline $\mathrm{UIr}_{2}$ & $F \subset c$ & $a=7.509$ & 8 & 19.62 & & $F d 3 m$ & $\mathrm{Cl} 15, \mathrm{MgCu}_{2} \mathrm{st}$ \\
\hline
\end{tabular}

\section{References}

(1) Park, J. J., private communication (October, 1956).

(2) Heal, T. J., and Williams, G. I., "Compounds of Uranium With the Transition Metals of the Second and Third Long Periods", Acta Cryst., 8, 494 (1955).

\section{URANIUM-IRON}

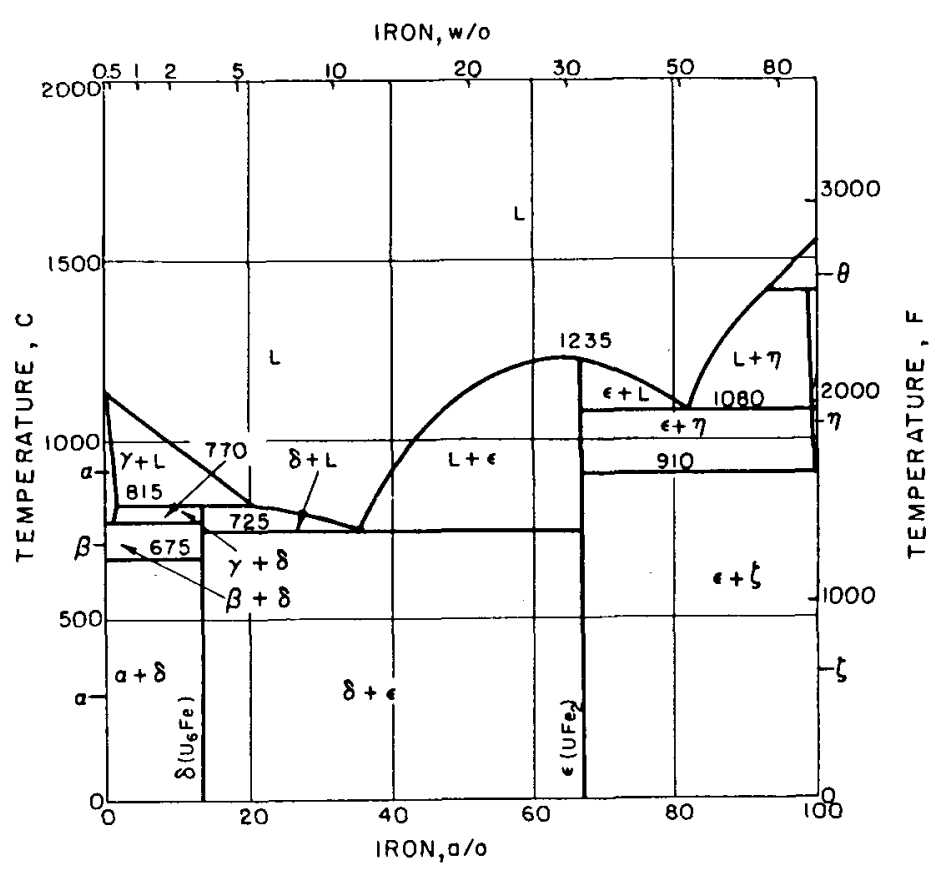


The uranium-iron diagram has been determined independently by Kaufmann( 1 ) and by Grogan (2) and has been studied by Foote(3). The diagram shown is Kaufmann's. The liquidus points and the isotherms reported by Grogan vary slightly from those of this diagram; otherwise, the two diagrams are identical.

Grogan(2) reports some details of the uranium-rich alloys. Solubilities of iron in uranium taken from this work are tabulated below.

\begin{tabular}{|c|c|c|}
\hline Phase & Temperature & Solubility, w/ \\
\hline Alpha & $\begin{array}{l}660 \mathrm{C} \\
\text { Alpha-beta isotherm }\end{array}$ & $\begin{array}{l}\mathrm{Nil} \\
<0.02 \text { iron }\end{array}$ \\
\hline Beta & $\begin{array}{l}\text { Alpha-beta isotherm } \\
\text { Beta-gamma isotherm }\end{array}$ & $\begin{array}{l}<0.02 \text { iron } \\
0.1 \text { iron }\end{array}$ \\
\hline Gamma & $\begin{array}{l}\text { Beta-gamma isotherm } \\
\mathrm{U}_{6} \mathrm{Fe} \text { peritectic }\end{array}$ & $\begin{array}{l}0.2 \text { iron } \\
0.35 \text { iron }\end{array}$ \\
\hline
\end{tabular}

The solubility in the gamma region depicted in the accompanying diagram(1) agrees well with the data above.

\section{Crystallography}

The structure of $\mathrm{U}_{6} \mathrm{Fe}$ has been determined by Baenziger(4) and is isomorphous with $\mathrm{U}_{6} \mathrm{Mn}, \mathrm{U}_{6} \mathrm{Co}$, and $\mathrm{U}_{6} \mathrm{Ni}$. The observed unit-cell volume for $\mathrm{U}_{6} \mathrm{Fe}\left(557 \mathrm{~A}^{3}\right)$ is quite close to the volume calculated by assuming additivity of atomic volumes $\left(547 \mathrm{~A}^{3}\right)$.

The data tabulated for $\mathrm{UFe}_{2}$ are from the work of Grogan(2). Kaufmann(1) has reported a slightly higher value for the lattice, $a=7.050 \mathrm{~A}$. Similar data have been reported by Baenziger (4) and Brook(5), indicating that $\mathrm{UFe}_{2}, \mathrm{UMn}_{2}$, and $\mathrm{UCo}_{2}$ are isomorphous and are the CI5-type $\mathrm{MgCu}_{2}$ structure. The compound $\mathrm{UNi}_{2}$ is reported to have the C14-type $\mathrm{MgZn}_{2}$ structure. Ternary alloys involving all of these phases are described in the section devoted to ternary alloys.

\begin{tabular}{|c|c|c|c|c|c|c|c|}
\hline \multirow[b]{3}{*}{ Phase } & \multicolumn{3}{|c|}{ Unit Cell } & & & \multirow{3}{*}{$\begin{array}{l}\text { Space } \\
\text { Group }\end{array}$} & \multirow[b]{3}{*}{ Remarks } \\
\hline & \multirow[b]{2}{*}{ Type } & \multirow{2}{*}{$\begin{array}{c}\text { Dimensions, } \\
\mathrm{A} \\
\end{array}$} & \multirow{2}{*}{ 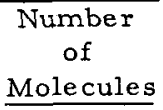 } & \multicolumn{2}{|c|}{$\begin{array}{c}\text { Density, } \\
\text { g/cm }\end{array}$} & & \\
\hline & & & & X-Ray & Other & & \\
\hline $\begin{array}{l}\text { Delta } \\
\left(\mathrm{U}_{6} \mathrm{Fe}\right)\end{array}$ & $\begin{array}{l}\text { Bc tetrag- } \\
\text { onal }\end{array}$ & $\begin{aligned} a= & 10.31 \pm \\
& 0.04 \\
c= & 5.24 \pm \\
& 0.02\end{aligned}$ & 4 & 17.7 & & $\begin{array}{l}\mathrm{I} 4 / \mathrm{mcm} \\
142 \text {, or } \\
\mathbb{1 4} \mathrm{c} 2\end{array}$ & $\begin{array}{l}\text { Is omorphous with } \\
\mathrm{U}_{6} \mathrm{Mn}, \mathrm{U}_{6} \mathrm{Co} \\
\mathrm{U}_{6} \mathrm{Ni}\end{array}$ \\
\hline $\begin{array}{r}\text { Epsilon } \\
\left(\mathrm{UFe}_{2}\right)\end{array}$ & $\mathrm{Fcc}$ & $a=7.042$ & 8 & 13.21 & & $\mathrm{Fd} 3 \mathrm{~m}$ & $\begin{array}{l}\text { C15-type, } \mathrm{MgCu}_{2} \\
\text { structure iso- } \\
\text { morphous with } \mathrm{UAl}_{2}\end{array}$ \\
\hline
\end{tabular}

\section{References}

(1) Gordon, P., Kaufmann, A. R., "The Alloy Systems Uranium-Aluminum and UraniumIron" (AECD-2683), J. Metals, 2 (1), 182 (1950).

(2) Grogan, J. D., "The Uranium-Iron System", J. Inst. Metals, 77, 571-580 (1950).

(3) Foote, Frank, unpublished information (1945).

(4) Baenziger, N. C., Rundle, R. E., Snow, A. I., and Wilson, A. S., "Compounds of Uranium with the Transition Metals of the First Long Period" (AECD-2598), Acta Cryst., 3 , 34-40 (1950).

(5) Brook, G. B., Williams, G. I., and Smith, E. M., "Pseudo-Binary Phase Sections Between Laves Phases in Ternary Alloys of Uranium", J. Inst. Metals, 83, 271 (1954-1955). 


\section{URANIUM-LANTHANUM}

Uranium and lanthanum show little miscibility in the liquid state. $(1,2)$ The solubility of lanthanum in liquid uranium is reported to be $0.75 \mathrm{w} / 0$ at $1150 \mathrm{C}$ and $0.90 \mathrm{w} / 0$ at $1250 \mathrm{C}$, while uranium solubility in lanthanum is given as $0.3 \mathrm{w} / 0$ at $1000 \mathrm{C}$ and $1.0 \mathrm{w} / 0$ at $1250 \mathrm{C}$. (1)

\section{Crystallography}

Data concerning the possibility of compounds in this system are not available.

\section{References}

(1) Wilhelm, H. A., "Nuclear Fuels Newsletter", WASH-704 (December, 1957). Classified.

(2) National Physical Laboratory, United Kingdom, unpublished information (1949-1950).

\section{URANIUM-LEAD}

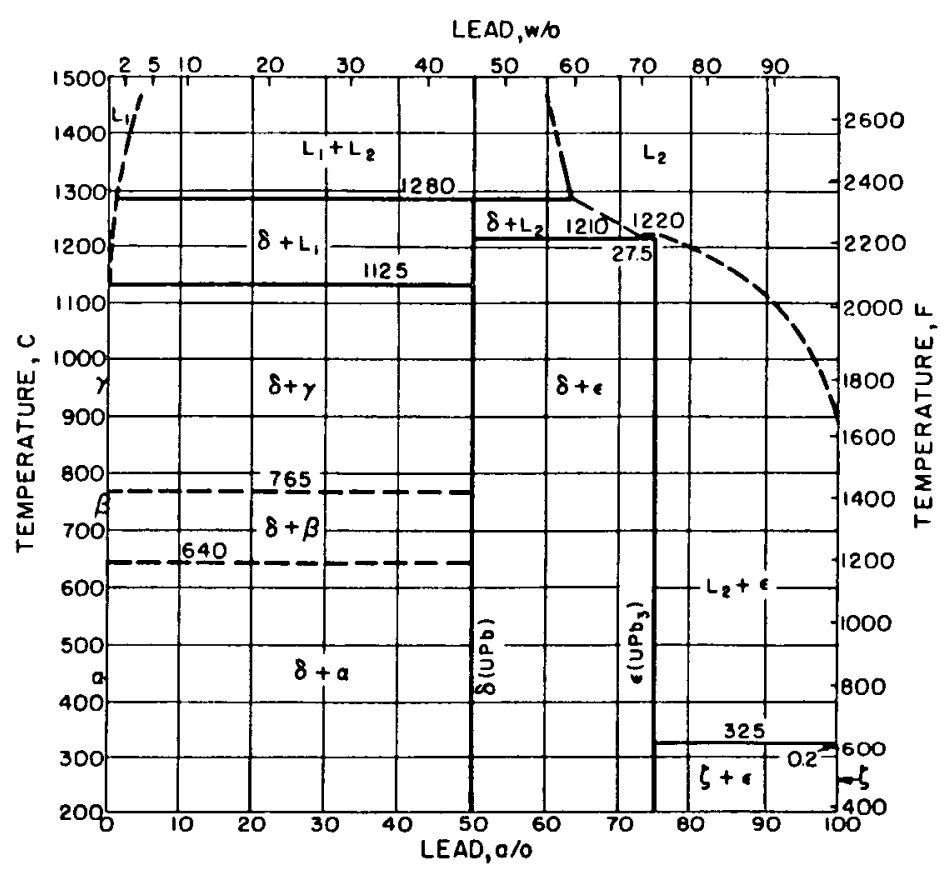

\section{The Constitutional Diagram}

The major features of the uranium-lead system are agreed upon by all investigators. The diagram shown is from Teitel(1). The results of Maskrey and Frost(2) differ only in that the compound delta (UPb) is shown to melt congruently at $1280 \mathrm{C}$ and no region of immiscibility is shown above $1280 \mathrm{C}$. The interpretation of Maskrey and Frost $(2)$ is based on thermal analyses, while Teitel( 1$)$ depicts the immiscibility gap on the basis of chemical analyses of liquated alloy samples. Separated layers formed by liquation analyzed 41 to $43 \mathrm{w} / \mathrm{o}$ uranium and 97.4 to $98.5 \mathrm{w} / \mathrm{o}$ uranium. It is difficult to account for such a large difference in composition unless a region of immiscibility exists.

The compounds $\mathrm{UPb}$ and $\mathrm{UPb}_{3}$ are pyrophoric and are therefore difficult to study. The compound $\mathrm{UPb}$ is reported to be more pyrophoric than is $\mathrm{UPb}_{3}(2)$.

The solubility of lead in uranium is quite low, and lead additions have little effect on the phase transformations in uranium. The uranium-rich eutectic is reported to occur at $99.6 \mathrm{w} / \mathrm{o}$ uranium. (2)

The solubility of uranium in lead has been determined by Teitel(5), who quotes solubilities of $0.002,0.046,0.26$, and $0.59 \mathrm{w} / 0$ at $416,612,806$, and $1000 \mathrm{C}$, respectively. 
The structure of $\mathrm{UPb}$ has been reported by Teitel (5). Numerous determinations of the structure of $\mathrm{UPb}_{3}$ have been made, and parameters of $4.73 \mathrm{~A}(4), 4.795 \mathrm{~A}(3)$, and $4.7934 \mathrm{~A}(2)$ have been reported. The structure in the tabulation is from Maskrey and Frost(2), but the parameter is from Teitel(5).

\begin{tabular}{|c|c|c|c|c|c|c|c|}
\hline \multirow[b]{3}{*}{ Phase } & \multicolumn{3}{|c|}{ Unit Cell } & & & \multirow{3}{*}{$\begin{array}{l}\text { Space } \\
\text { Group }\end{array}$} & \multirow[b]{3}{*}{ Remarks } \\
\hline & \multirow[b]{2}{*}{ Type } & \multirow{2}{*}{$\begin{array}{c}\text { Dimensions, } \\
\mathrm{A} \\
\end{array}$} & \multirow{2}{*}{$\begin{array}{c}\text { Number } \\
\text { of } \\
\text { Molecules } \\
\end{array}$} & \multicolumn{2}{|c|}{$\begin{array}{r}\begin{array}{c}\text { Density, } \\
\mathrm{g} / \mathrm{cm}^{3}\end{array} \\
\end{array}$} & & \\
\hline & & & & X-Ray & Other & & \\
\hline $\begin{array}{l}\text { Delta } \\
\text { (UPb) }\end{array}$ & $\begin{array}{l}\text { Bc tetrag- } \\
\text { onal }\end{array}$ & $\begin{array}{l}a=11.04 \\
c=10.60\end{array}$ & 48 & 13.7 & -- & -- & -- \\
\hline $\begin{array}{r}\text { Epsilon } \\
\left(\mathrm{UPb}_{3}\right)\end{array}$ & $\begin{array}{r}\text { Simple } \\
\text { cubic }\end{array}$ & $a=4.791$ & 1 & 12.98 & -- & $\mathrm{Pm} 3 \mathrm{~m}$ & $\begin{array}{l}\mathrm{LI2}, \mathrm{AuCu}_{3} \text { ordered } \\
\text { structure iso- } \\
\text { morphous with } \\
\mathrm{UAl}_{3}, \mathrm{UGa}_{3} \text {, UIn } 3 \text {, } \\
\mathrm{USi}_{3}, \mathrm{UGe}_{3} \text {, and } \\
\mathrm{USn}_{3} \text {. }\end{array}$ \\
\hline
\end{tabular}

References

(1) Teitel, R. J., "The Lead-Uranium System" (AECD-3173), J. Metals, 4, 397-400 (1952).

(2) Frost, B.R.T., and Maskrey, J. T., "The System Uranium-Lead" (AERE-M/R 1027) J. Inst. Metals, 82 (1), 171-180 (1953).

(3) Fitzpatrick, J. M., and Kaufmann, A. R., unpublished information (1950).

(4) Iandelli, A., and Ferro, R., Ann, chim. (Rome), 42, 598-606 (1952).

(5) Teitel, R. J., "The Uranium-Lead System", J. Inst. Metals, 85, 409-412 (1956-57).

\section{URANIUM-LUTECIUM}

Uranium and lutecium exhibit an immiscibility gap in the liquid state. Solubility of lutecium in liquid uranium is reported to increase from $0.2 \mathrm{w} / 0$ at $1150 \mathrm{C}$ to $0.4 \mathrm{w} / \mathrm{o}$ at $1250 \mathrm{C} .(1)$

\section{Crystallography}

Nothing is known concerning the possibility of compounds in this system.

\section{Reference}

(1) Wilhelm, H. A., "Nuclear Fuels Newsletter", WASH-704 (December, 1957). Classified. 


\section{URANIUM-MAGNESIUM}

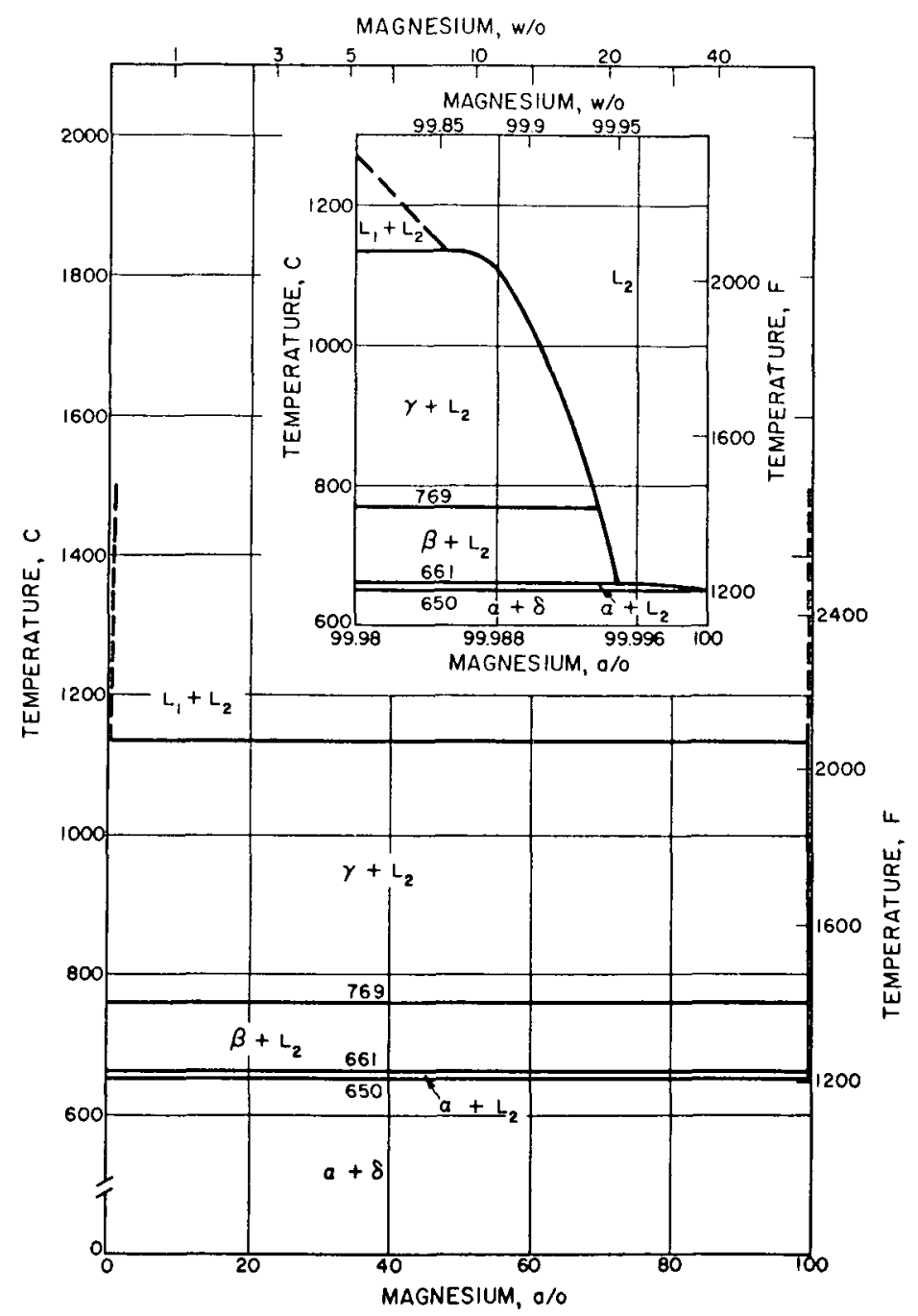

\section{The Constitutional Diagram}

The magnesium-uranium diagram shown has been worked out by investigators at Ames Laboratory. (1) The immiscibility of the two metals has been cited by other $(2,3)$.

Early work on this system gave evidence of intermetallic phases and thus led to a faulty conception of the system. The later work of Tracy, Chiotti, and Wilhelm(1) provides not only a complete diagram but also an explanation of early erroneous information. It was found that the method of preparation of diffusion and liquation samples was important; if magnesium and uranium we re heated togethe $r$ in ordinary crucible materials, uranium carbide or uranium silicide layers, depending on the refractory material, were formed between the uranium and magnesium layers.

Two techniques were found to be especially successful in this work. The first involves heating massive uranium or uranium shavings in molten magnesium in a crucible consisting of $90 \mathrm{w} / 0$ magnesium oxide and $10 \mathrm{w} / 0$ magnesium fluoride. The other technique consists of melting magnesium and holding it molten in a uranium container. Both methods avoid collection of contaminants at the interface of the two immiscible metals(l).

Diffusion samples prepared by holding magnesium in a uranium crucible for $24 \mathrm{hr}$ at $.1015 \mathrm{C}$ showed no evidence of diffusion bands or intermetallic compounds, (1) The work described appears to be quite thorough, since a variety of techniques, including thermal analy sis, $\mathrm{X}$-ray studies, microscopic examination and diffusion or liquation tests were utilized.(1) 
Uranium and magnesium are almost completely immiscible, even at high temperatures. At $1150 \mathrm{C}$ and 3 -atm pressure, $0.14 \mathrm{w} / 0$ uranium is soluble in magnesium, while only $0.004 \mathrm{w} / \mathrm{o}$ magnesium is soluble in uranium. The solubility of uranium in magnesium is re ported to decrease to $0.05 \mathrm{w} / 0$ at $675 \mathrm{C}$ and to $0.005 \mathrm{w} / 0$ at $650 \mathrm{C}$. (1) In a more recent determination of uranium solubilities in magnesium, values of $0.002 \mathrm{w} / \mathrm{o}$ at $650 \mathrm{C}$ and of $0.17 \mathrm{w} / \mathrm{o}$ at $1132 \mathrm{C}$ were obtained. (4)

The melting points of magnesium and uranium and the transformation temperatures in uranium are affected very little in the se alloys.

\section{Crystallography}

There are no compounds in the uranium-magnesium system.

\section{References}

(1) Chiotti, P., Tracy, G. A., and Wilhelm, H. A., "Magnesium-Uranium Alloy System", Trans. AIME, 206, 562-67 (1956).

(2) A.E.R.E., United Kingdom, unpublished information (March, 1947).

(3) Iandelli, Aldo, and Ferro, Ricardo, Ann. chim. (Rome), 42, 598-600 (1952).

(4) Wilhelm, H. A., "Nuclear Fuels Newsletter", WASH-704, 2-4 (December, 1957). Classified.

\section{URANIUM-MANGANESE}

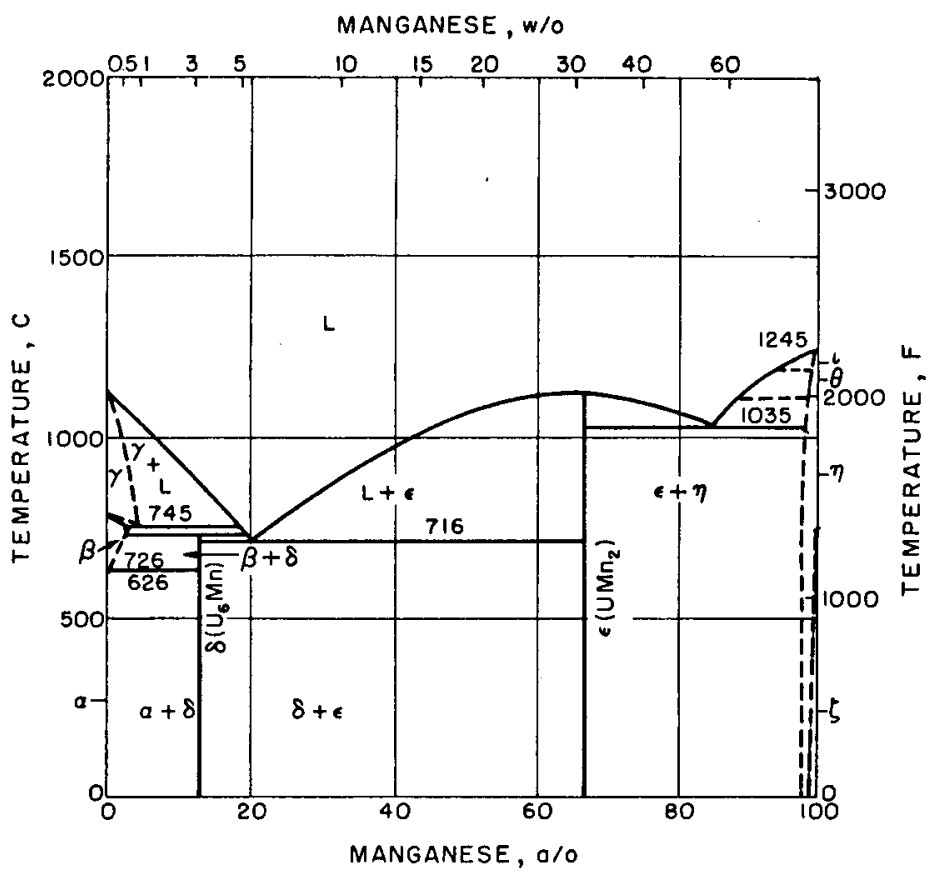

\section{The Constitutional Diagram}

The constitutional diagram of uranium-manganese is shown in the accompanying figure(1). The system has two intermetallic compounds, $\mathrm{U}_{6} \mathrm{Mn}$ and $\mathrm{UMn}_{2}$. The general characteristics of the system are confirmed by data from the United Kingdom. (2) Although some difference in data occurs at the manganese end of the system, there is not enough information 
available to evaluate this region. Data from the United Kingdom(2) indicate that gamma manganese, designated theta, is stabilized to room temperature by small additions of uranium. On the other hand, Wilhelm(1) reports that beta manganese, designated as zeta, is stabilized to room temperature in the region between epsilon ( $\mathrm{UMn}_{2}$ ) and 100 per cent manganese. All data indicate that uranium is soluble in manganese to some extent, but little actual detail is known.

It has been reported(2) and confirmed(3) that beta uranium can be retained by small additions of manganese.

The solubility of manganese in uranium has been reported to be less than 4.3 a/o manganese $(1 \mathrm{w} / 0)$ in the gamma and about 1.1 a/o manganese at $626 \mathrm{C}^{(1)}$.

\section{Crystallography}

The structures of $\mathrm{U}_{6} \mathrm{Mn}$ and $\mathrm{UMn}_{2}$ are described in the tabulation. The intermetallic compound $U_{6} \mathrm{Mn}$ has been thoroughly studied by Baenziger (4) and is isomorphous with $\mathrm{U}_{6} \mathrm{Fe}$, $\mathrm{U}_{6} \mathrm{Co}, \mathrm{U}_{6} \mathrm{Ni}$. It has a unit cell volume of about $550 \mathrm{~A}^{3}$, which is quite close to the volume determined or estimated by addition of atomic volumes. The atomic positions can be described on the basis of space group $14 / \mathrm{mcm}$, although a possible variation from these positions in space groups $I 42$ and $I \overline{4} \mathrm{c} 2$ has not been eliminated.

Nearly identical data have been reported for $\mathrm{UMn}_{2}$ by Baenziger ${ }^{(4)}$ and by Bowles (5). The data tabulated are from Baenziger. The compound $\mathrm{UMn}_{2}$ is the C15-type $\mathrm{MgCu}_{2}$ structure. Bowles reports the lattice constant to be $a=7.146 \mathrm{~A}$. The compound $\mathrm{UMn}_{2}$ is isomorphous with $\mathrm{UCo}_{2}$ and $\mathrm{UFe}_{2}$ and may be isomorphous with other uranium compounds. The compound UNi $\mathrm{UN}_{2}$, however, is unique and crystallizes in the Cl4-type $\mathrm{MgZn}_{2}$ structure. Ternary alloys involving these phases are reported in the section devoted to ternary alloys.

\begin{tabular}{|c|c|c|c|c|c|c|c|}
\hline \multirow[b]{3}{*}{ Phase } & \multicolumn{3}{|c|}{ Unit Cell } & & & \multirow{3}{*}{$\begin{array}{l}\text { Space } \\
\text { Group }\end{array}$} & \multirow[b]{3}{*}{ Remarks } \\
\hline & \multirow[b]{2}{*}{ Type } & \multirow{2}{*}{$\begin{array}{c}\text { Dimensions, } \\
\mathrm{A} \\
\end{array}$} & \multirow{2}{*}{$\begin{array}{c}\begin{array}{c}\text { Number } \\
\text { of } \\
\text { Molecules }\end{array} \\
\end{array}$} & \multicolumn{2}{|c|}{$\begin{array}{r}\begin{array}{c}\text { Density, } \\
\mathrm{g} / \mathrm{cm}^{3}\end{array} \\
\end{array}$} & & \\
\hline & & & & X-Ray & Other & & \\
\hline $\begin{array}{l}\text { Delta } \\
\text { (U } \mathrm{U}_{6} \mathrm{Mn} \text { ) }\end{array}$ & $\begin{array}{l}\text { Be tetrag- } \\
\text { onal }\end{array}$ & $\begin{array}{l}a=10.20 \\
c=5.24\end{array}$ & 4 & 17.8 & & $\begin{array}{l}\mathrm{I} 4 / \mathrm{mcm}, \\
\mathrm{I} 42 \text { or } \\
\mathrm{I} \overline{4} \mathrm{c} 2\end{array}$ & $\begin{array}{l}\text { Isomorphous with } \\
\mathrm{U}_{6} \mathrm{Fe}, \mathrm{U}_{6} \mathrm{Ni} \text { and } \\
\mathrm{U}_{6} \mathrm{Co}\end{array}$ \\
\hline $\begin{array}{l}\text { Epsilon } \\
\text { (UMn2) }\end{array}$ & $\mathrm{Fcc}$ & $\begin{aligned} a= & 7.1484 \pm \\
& 0.0014\end{aligned}$ & 8 & 12.57 & & $\mathrm{Fd}_{3} \mathrm{~m}$ & $\begin{array}{l}\text { C15-type, } \mathrm{MgCu}_{2} \\
\text { structure; iso- } \\
\text { morphous with } \\
\mathrm{UFe}_{2} \text { and } \mathrm{UCo}_{2}\end{array}$ \\
\hline
\end{tabular}

References

(1) Wilhelm, H. A., and Carlson, O. N., "The Uranium-Manganese and Uranium-Copper Alloy Systems" (AECD-2717), Trans. Am. Soc. Metals, $\underline{42}, 1311$ (1950).

(2) A.E.R.E., United Kingdom, unpublished information (May, 1950).

(3) Saller, H. A., and Rough, F. A., private communication (1949).

(4) Baenziger, N. C., Rundle, R. E., Snow, A. I., and Wilson, A. S., "Compounds of Uranium with Transition Metals of the First Long Period" (AECD-2598), Acta Cryst., 3 , $34-40(1950)$.

(5) Bowles, P. I., Hutchison, T. S., Pfeil, P.C.L., and Waldron, M. B., "The Crystal Structure of the Compound UMn 2 and a Discussion of Laves Phases in Uranium Alloys", AERE-M/R 581 (October, 1950). 


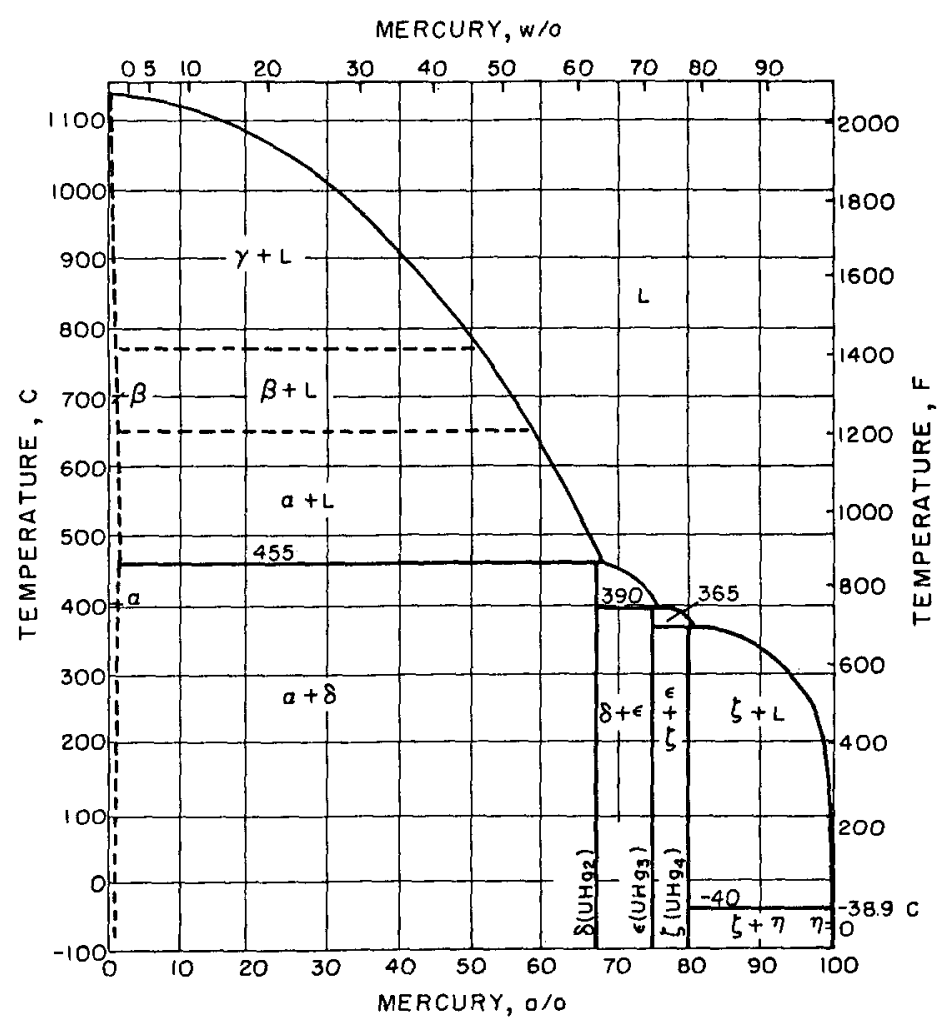

The Constitutional Diagram

The uranium-mercury system has been studied by Wilson $(1)$ and by Frost ${ }^{(2)}$, with virtually identical results. The essential difference was that Frost studied the system by sealing samples and allowing the pressure to rise, while Wilson worked at a pressure of $1 \mathrm{~atm}$. The diagram shown is that of Frost(2). Since data above the boiling point of mercury (358 C) were obtained by means of a sealed system, the pressure varied and was as high as several hundred atmos pheres.

The diagram of Wilson(1) is identical, except that mercury vapor was in equilibrium with the uranium-mercury compounds and with uranium above the boiling point of mercury.

This is a very difficult system to study. A special means of preparing alloys is necessary, the high vapor pressure of mercury presents a special problem, and the intermetallic compounds are pyrophoric in nature and therefore require special techniques in handling.

It is of interest that Wilson and Frost used the same method of alloy preparation. Essentially, it consists of hydriding uranium, dehydriding under vacuum, and reacting mercury with the resulting uranium powder.

\section{Crystallography}

The tabulated data for $\mathrm{UHg}_{2}, \mathrm{UHg}_{3}$ and $\mathrm{UHg}_{4}$ are from Rundle(3). Frost has reported similar information for $\mathrm{UHg}_{2}$ and $\mathrm{UHg}_{3}$ but was unable to obtain a more certain analysis of the $\mathrm{UHg}_{4}$ structure. According to Frost, $\mathrm{UHg}_{2}$ has a complex hexagonal structure with $\mathrm{a}=4.934 \mathrm{~A}$ and $\mathrm{c}=3.503 \mathrm{~A}$, while $\mathrm{UHg}_{3}$ is close-packed hexagonal with $\mathrm{a}=3.320 \mathrm{~A}$ and $c=4.875 \mathrm{~A}$. The $\mathrm{UHg}_{3}$ structure is reported to be a random structure. (1)

It is reported that the unit cell volumes of these compounds, within the limit of accuracy of the work, are equal to the additive atomic volumes. This equivalence is interpreted to mean that the binding is purely metallic in nature. (1) 


\begin{tabular}{|c|c|c|c|c|c|c|c|}
\hline \multirow[b]{3}{*}{ Phase } & \multicolumn{3}{|c|}{ Unit Cell } & \multirow{2}{*}{\multicolumn{2}{|c|}{$\begin{array}{c}\text { Density, } \\
\mathrm{g} / \mathrm{cm}^{3}\end{array}$}} & \multirow{3}{*}{$\begin{array}{l}\text { Space } \\
\text { Group }\end{array}$} & \multirow[b]{3}{*}{ Remarks } \\
\hline & & Dimensions, & $\begin{array}{c}\text { Number } \\
\text { of }\end{array}$ & & & & \\
\hline & Type & $\mathrm{A}$ & Molecules & X-Ray & Other & & \\
\hline $\begin{array}{l}\text { Delta } \\
\left(\mathrm{UHg}_{2}\right)\end{array}$ & Hexagonal & $\begin{aligned} \mathrm{a}= & 4.99 \pm \\
& 0.01 \\
\mathrm{c}= & 3.23 \pm \\
& 0.01\end{aligned}$ & 1 & 15.29 & 15.3 & $\mathrm{C} 6 / \mathrm{mmm}$ & $\begin{array}{l}\text { C32-type, } \\
\text { AlB }_{2} \text { structure }\end{array}$ \\
\hline $\begin{array}{l}\text { Epsilon } \\
\left(\mathrm{UHg}_{3}\right)\end{array}$ & Hexagonal & $\begin{aligned} a= & 3.327 \pm \\
& 0.005 \\
c= & 4.888 \pm \\
& 0.005\end{aligned}$ & $1 / 2$ & 14.88 & & & \\
\hline $\begin{array}{l}\text { Zeta } \\
\left(\mathrm{UHg}_{4}\right)\end{array}$ & $\mathrm{Bcc}$ & $a=3.63$ & 2 & 14.5 & & & $\begin{array}{l}\text { Tentative } \\
\text { analysis }\end{array}$ \\
\hline
\end{tabular}

References

(1) Wilson, A. S., Ahmann, D. H., and Baldwin, R. R., "The Uranium-Mercury System", CT-2960 (October, 1945).

(2) Frost, B.R. T., "The System Uranium-Mercury" (AERE-M/R 1208), I. Inst. Metals, $82(9), 456-462$ (1954).

(3) Rundle, R. E., and Wilson, A. S. "The Structures of Some Metal Compounds" (AECD-2388), Acta Cryst., 2, 148-150 (1949).

\section{URANIUM-MOLYBDENUM}

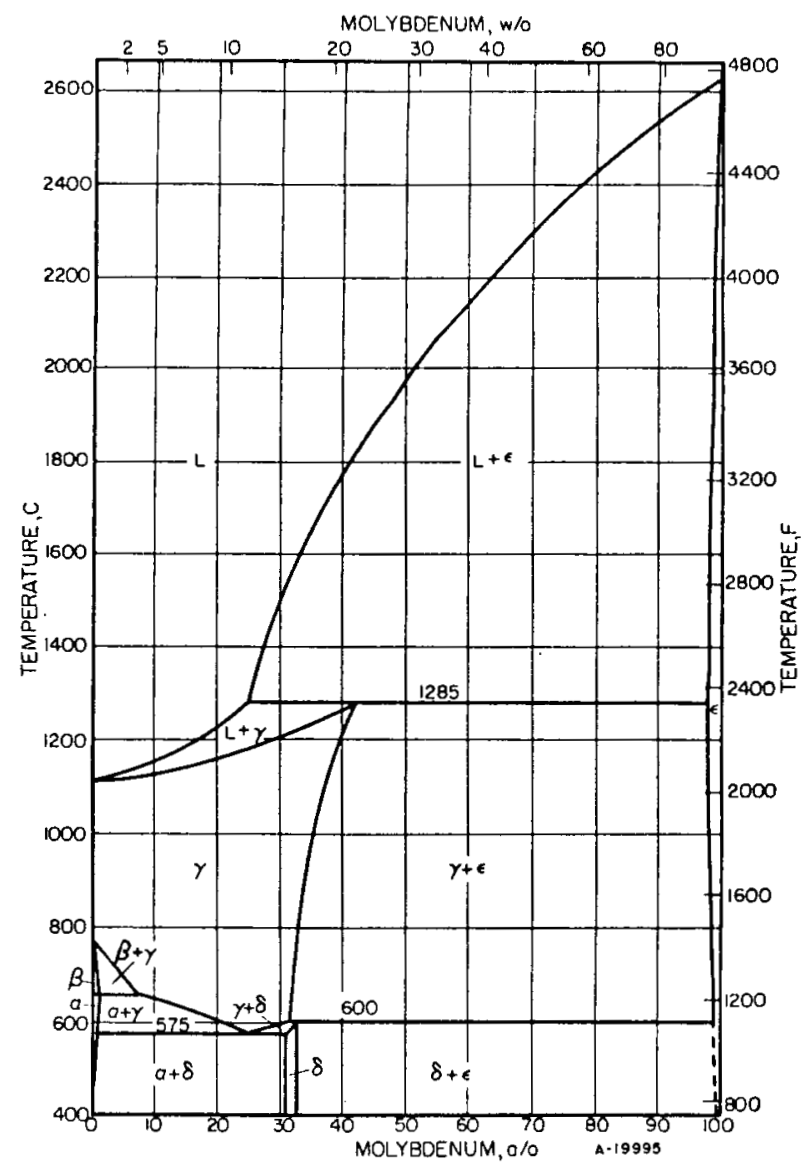


The uranium-molybdenum system was studied first by $A$ hmann(1), who interpreted the system much as it is now except that the gamma phase was reported to be stabilized to room temperature in the vicinity of 25 to 30 a/o molybdenum. A somewhat similar report was issued independently by Pfeil(2). It was then shown that the gamma phase is metastable, and, although relatively long periods of time are necessary to transform the gamma, a different phase is stable below about 575 to $600 \mathrm{C}(3,4,5)$.

Work by Halteman and Lustman(6) and by Pfeil and Browne(7) has been concentrated on the region of metastable gamma alloys. Early results indicated that the intermediate delta phase exhibited a wide solubility range from about 20 to 33 a/o molybdenum at the isotherm temperatures. When annealing times on the order of a month are involved, this wide solubility range is observed. However, Halteman $(8)$ has since demonstrated that still more prolonged annealing narrows the region to about 31.5 to 32.5 a/o molybdenum. The diagram shown is based upon the se results and confirms the earlier interpretation of Saller, Rough, and Vaughan (3).

There appears to be some difference of opinion regarding the solubility of molybdenum in alpha uranium. Pfeil(2) has reported a peritectoid alpha formation with a solubility of about 3 or 4 a/o molybdenum in alpha. This report is contrary to the work of both Ahmann (1) and Saller(3), who carried out an intensive study of this region. It is true that several a/o of molybdenum can be retained in what might be described as a supersaturated, or distorted, alphalike structure. However, cold working followed by annealing for long periods produces; two-phase structures that indicate a maximum solubility of about 0.5 a/o molybdenum, or less, in the alpha. Thermal analyses also indicate a lowering of the beta-to-alpha transformation, even during heating(3). The maximum solubility in the beta phase is about 1.0 a/o molybdenum. It has been demonstrated that the beta phase can be retained to room temperature by quenching alloys of about $\mathrm{l}$ a/o molybdenum. The retained structure is metastable and transforms slowly during long periods of room-temperature aging. (3)

The solubility of uranium in molybdenum is quite limited and appears to be a maximum of about 2 a/o uranium at $1285 \mathrm{C}(9)$.

\section{Crystallography}

The delta phase has been studied by a number of investigators, and it is generally agreed that it is an ordered structure. The data in the tabulation are from the work of Halteman(8), who reports that the tetragonal delta phase is of the Cllb MoSi 2 type and can be considered as an ordered form of gamma in which the molybdenum atoms assume special positions in a unit cell composed of three body-centered pseudocubes.

Pfeil and Browne(7) had earlier reported the structure to be body-centered tetragonal with $\mathrm{a}=3.425 \mathrm{~A}$ and $\mathrm{c}=3.282 \mathrm{~A}$, which is the same structure reported by $\mathrm{Tucker}(4)$. However, the diffraction pattern reported by Tucker was found to be incomplete; also, the observed intensities could not be accounted for on the basis of this structure. Upon this basis, Saller (3) and Halteman $(6)$ had proposed a body-centered tetragonal phase with a $=6.84 \mathrm{~A}$ and $c=6.55 \mathrm{~A}$. However, the more detailed analysis of Halteman( $(8)$ leads to the tetragonal cell with $a=3.427 \mathrm{~A}$ and $\mathrm{c}=9.834$.

\begin{tabular}{|c|c|c|c|c|c|c|c|}
\hline \multirow[b]{3}{*}{ Phase } & \multicolumn{3}{|c|}{ Unit Cell } & \multirow{2}{*}{\multicolumn{2}{|c|}{$\begin{array}{c}\text { Density, } \\
\mathrm{g} / \mathrm{cm}^{3}\end{array}$}} & \multirow{3}{*}{$\begin{array}{l}\text { Space } \\
\text { Group }\end{array}$} & \multirow[b]{3}{*}{ Remarks } \\
\hline & & Dimensions, & $\begin{array}{c}\text { Number } \\
\text { of }\end{array}$ & & & & \\
\hline & Type & $\mathrm{A}$ & Molecules & X-Ray & Othe $\mathbf{r}$ & & \\
\hline Delta & Tetragonal & $\begin{array}{l}a=3.427 \\
c=9.834\end{array}$ & 2 & -- & 16.63 & $14 / \mathrm{mmm}$ & $\begin{array}{l}\text { Cllb-type isomorphous } \\
\text { with } \mathrm{MoSi}_{2}, \mathrm{WSi}_{2} \text {, } \\
\operatorname{ReSi}_{2}, \mathrm{AlC}_{2} \text {, and } \\
\mathrm{MgH}_{2}\end{array}$ \\
\hline
\end{tabular}




\title{
References
}

(1) Ahmann, D., Snow, A. I., and Wilson, A. S., "The Uranium-Molybdenum Binary System", CT-2946 (July, 1945).

(2) Pfeil, P. C. L., "The Constitution of Uranium-Molybdenum Alloys", J. Inst. of Metals, 77, 553- $70(1950-51)$.

(3) Saller, H. A., Rough, F. A., and Vaughan, D. A. , "The Constitution Diagram of Uranium-Rich Uranium-Molybdenum Alloys", BMI- 72 (June, 1951).

(4) Tucker, C. W., "Discussion on 'The Constitution of Uranium-Molybdenum Alloys' " by P.C. L. Pfeil in the J. Inst. of Metals (AECD-3092), J. Inst. Metals, 78, 760 $(1950-51)$.

(5) Seybolt, A. U., "Discussion on 'The Constitution of Uranium-Molybdenum Alloys' " by P. C. L. Pfeil in the J. Inst. Metals (AECD-3093), J. Inst. Metals, 78, 760 (1950-51).

(6) Halteman, E. K., and Lustman, B., unpublished information (1954).

(7) Pfeil, P. C. L., and Browne, J. D., "Superlattice Formation in Uranium-Molybdenum Alloys", AERE M/R 1333 (1954).

(8) Halteman, E. K., "The Crystal Structure of $\mathrm{U}_{2} \mathrm{Mo}^{\prime}$, Acta Cryst., 10, 166-169 (March 10, 1957).

(9) Saller, H. A., Rough, F. A., and Bennett, D. C., "The Constitution of MolybdenumRich Uranium-Molybdenum Alloys", BMI- 730 (March, 1952).

\section{UR ANIUM-NEODYMIUM}

\author{
Neodymium is only partially miscible with uranium in the liquid state. $(1,2)$ The solu- \\ bility of neodymium in uranium is reported to increase from $0.15 \mathrm{w} / 0$ at $1150 \mathrm{C}$ to $0.2 \mathrm{w} / \mathrm{o}$ at \\ $1250 \mathrm{C}$. Solubility of uranium in neodymium is given as $1.1 \mathrm{w} / 0$ at $1000 \mathrm{C}$ and $2.0 \mathrm{w} / 0$ at \\ $1250 \mathrm{C} .(2)$ \\ Crystallography \\ Probably there are no compounds in the uranium-neodymium system.
}

\section{$\underline{\text { References }}$}

(1) National Physical Laboratory, United Kingdom, unpublished information (1949-1950).

(2) Wilhelm, H. A., "Nuclear Fuels Newsletter", WASH-704 (December, 1957). Classified. 


\section{URANIUM-NICKEL}

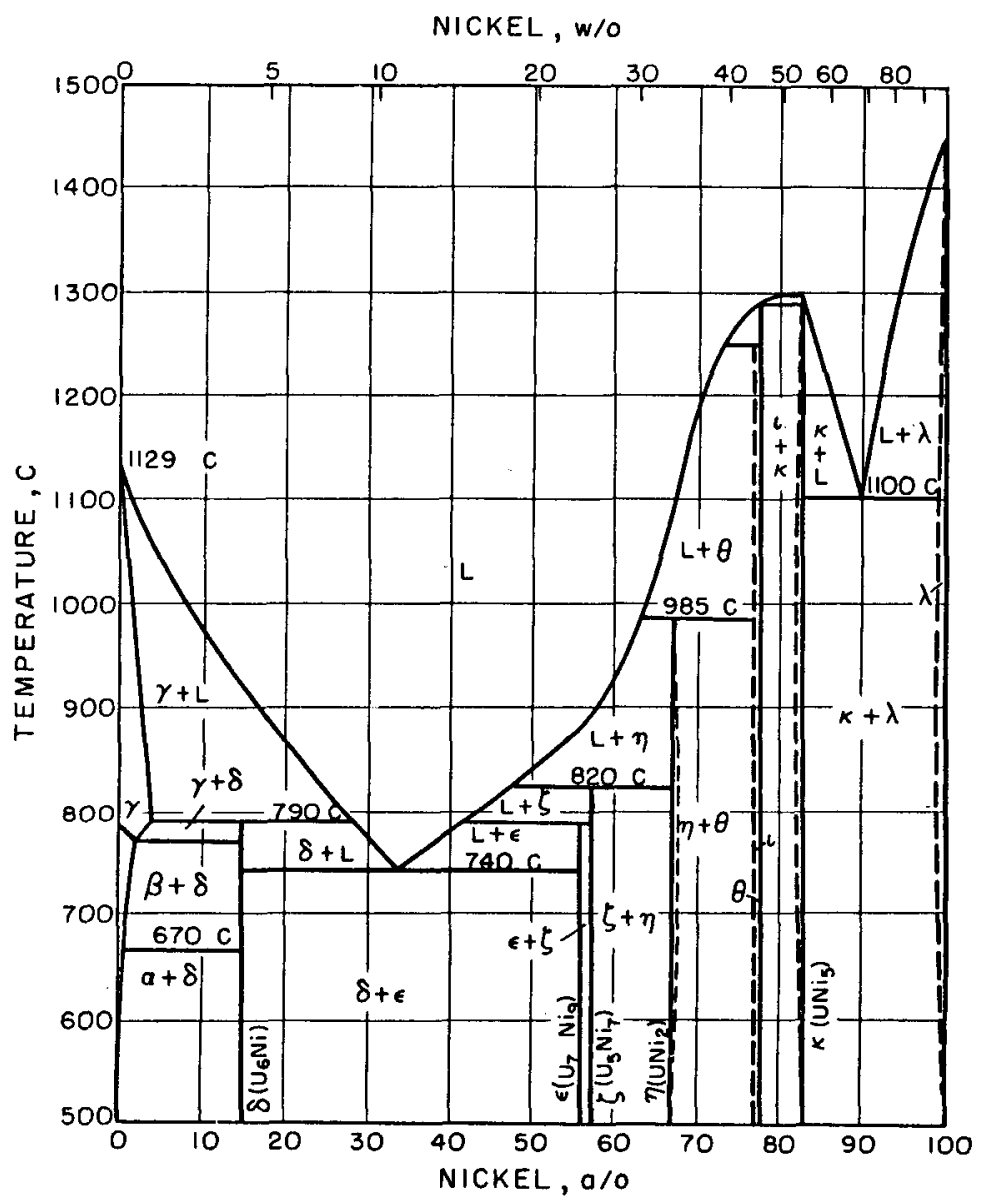

The Constitutional Diagram

The diagram shown for the uranium-nickel system is the work of Grogan and Pleasance (1). Its general shape is similar to that reported by Foote (2), except for the fact that Grogan reports seven intermetallic compounds while Foote reports only four. The structures of $\mathrm{U}_{6} \mathrm{Ni}, \mathrm{UNi}_{2}$, and $\mathrm{UNi}_{5}$ have been worked out by Baenziger(3). Attempts by Baenziger to analyze the X-ray pattern presumed to correspond to UNi revealed that the structure was too complex to interpret on the basis of the powder data available. Williams, in an appendix to the report of Grogan (1), has resolved X-ray data of alloys in this region into two separate patterns designated as $\mathrm{U}_{7} \mathrm{Ni} 9$ and $\mathrm{U}_{5} \mathrm{Ni}_{7}$, although the structures have not been determined.

Intermediate between $\mathrm{UNi}_{2}$ and $\mathrm{UNi}_{5}$, another pair of compounds has been proposed by Grogan. Patterns of X-ray diffraction maxima are reported for the se materials, although the structures have not been determined(1). The existence of both compounds was proposed after fairly elaborate heat-treating experiments and examination by a variety of techniques.

Alloys in the range of 40 to $47 \mathrm{w} / 0$ nickel were found to have some malleability and could be flattened with a hammer, although cracking occurred in the process. This behavior is reported $(1)$ to be unlike that of the other compounds, which were brittle.

The solubilities in the terminal phases are quite limited. $(1,2)$ Solubility in the gammauranium appears to be a maximum of about 2 a/o nickel at the $\mathrm{U}_{6} \mathrm{Ni}$ peritectic temperature. It decreases to about $1.25 \mathrm{a} / \mathrm{o}$ at the gamma-to-beta eutectoid. The beta solubility at the gamma-to-beta eutectoid appears to be about 1.0 a/o nickel and decreases sharply to perhaps 0.1 a $/ 0$ nickel at $700 \mathrm{C}$. The solubility of nickel in alpha uranium is quite small at all temperatures. 


\section{Crystallography}

The compound $\mathrm{U}_{6} \mathrm{Ni}$ together with the compounds $\mathrm{U}_{6} \mathrm{Fe}, \mathrm{U}_{6} \mathrm{Co}$, and $\mathrm{U}_{6} \mathrm{Mn}$ have been studied by Baenziger(3). All have a unit-cell volume nearly equal the volume obtained by addition of atomic values, or about $550 \mathrm{~A}^{3}$. The atomic positions can be described on the basis of space group $14 / \mathrm{mcm}$, although a possible variation from these positions in space groups 142 and $I \overline{4} \mathrm{c} 2$ has not been eliminated.

Nearly identical data have been reported for $\mathrm{UNi}_{2}$ by Baenziger( ${ }^{(3)}$ and by Bowles $(4)$. The data in the tabulation are from Baenziger. The UNi2 structure is the C14-type, $\mathrm{MgZn}_{2}$ structure, unlike $\mathrm{UFe}_{2}, \mathrm{UMn}_{2}$, and $\mathrm{UCo}_{2}$, which are the C15-type, $\mathrm{MgCu}_{2}$ structure. Ternary alloys involving these phases are reported in the section devoted to ternary alloys.

The structure of $\mathrm{UNi}_{5}$ has been studied by Baenziger(3) with the results tabulated below.

\begin{tabular}{|c|c|c|c|c|c|c|}
\hline \multirow[b]{3}{*}{ Phase } & \multicolumn{3}{|c|}{ Unit Cell } & \multirow{2}{*}{$\begin{array}{c}\text { Density } \\
\mathrm{g} / \mathrm{cm}^{3} \\
\end{array}$} & \multirow{3}{*}{$\begin{array}{l}\text { Space } \\
\text { Group }\end{array}$} & \multirow[b]{3}{*}{ Remarks } \\
\hline & & Dimensions, & $\begin{array}{c}\text { Number } \\
\text { of }\end{array}$ & & & \\
\hline & Type & $\mathrm{A}$ & Molecules & $\overline{\mathrm{X} \text {-Ray } \text { Other }}$ & & \\
\hline $\begin{array}{l}\text { De lta } \\
\qquad\left(\mathrm{U}_{6} \mathrm{Ni}^{\mathrm{Ni}}\right)\end{array}$ & $\begin{array}{l}\text { Bc te- } \\
\text { trago- } \\
\text { nal }\end{array}$ & 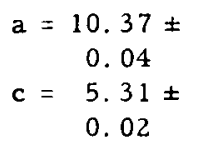 & 4 & 17.6 & $\begin{array}{l}\mathrm{I} 4 / \mathrm{mcm} \\
I 42 \text {, or } \\
I \overline{4} \mathrm{c} 2\end{array}$ & $\begin{array}{l}\text { Isomorphous with } \\
\mathrm{U}_{6} \mathrm{Fe}, \mathrm{U}_{6} \mathrm{Co} \text {, and } \\
\mathrm{U}_{6} \mathrm{Mn}\end{array}$ \\
\hline $\begin{array}{l}\text { Zeta } \\
\left(\mathrm{UNi}_{2}\right)\end{array}$ & $\begin{array}{l}\text { Hexago- } \\
\text { nal }\end{array}$ & $\begin{array}{l}a=4.966 \\
c=8.252\end{array}$ & 4 & 13.46 & $\mathrm{C} 6 / \mathrm{mmc}$ & $\begin{array}{l}\text { C14-type, } \mathrm{MgZn}_{2} \\
\text { structure }\end{array}$ \\
\hline $\begin{array}{l}\text { Kappa } \\
\left(\mathrm{UNi}_{5}\right)\end{array}$ & F cc & $\begin{aligned} a= & 6.7830 \pm \\
& 0.0005\end{aligned}$ & 4 & & $\begin{array}{c}\mathrm{F} \overline{4} 3 \mathrm{~m} \text { or } \\
\mathrm{F} 23\end{array}$ & $\begin{array}{l}\text { Similar to } \mathrm{MgCu}_{2} \\
\text { structure, but of } \\
\text { lower symmetry; iso- } \\
\text { morphous with } \mathrm{UCu}_{5} \text {, } \\
\operatorname{PdBe}_{5} \text {, and } \mathrm{AuBe}_{5}\end{array}$ \\
\hline
\end{tabular}

\section{References}

(1) Grogan, J. D., and Pleasance, R. J., "A Survey of the Uranium-Nickel System", J. Inst. Metals, 82, 141-147 (1953-54).

(2) Foote, Frank, Clark, J. R., Cieslicki, M., Nelson, B. J., and Lane, T. R., "The Tuballoy-Nickel Phase Diagram", CT-3013 (May, 1945).

(3) Baenziger, N. C., Rundle, R. E., Snow, A. I., and Wilson, A. S., "Compounds of Uranium With the Transition Metals of the First Long Period" (AECD-2598), Acta Cryst., $3,34-40(1950)$.

(4) Bowles, P. J., Hutchison, T. S., Pfeil, P. C. L., and Waldron, M. B., "The Crysta1 Structure of the Compound UMn2 and a Discussion of Laves Phases in Uranium Alloys", AERE-M/R 581 (October, 1950). 


\section{URANIUM-NIOBIUM}

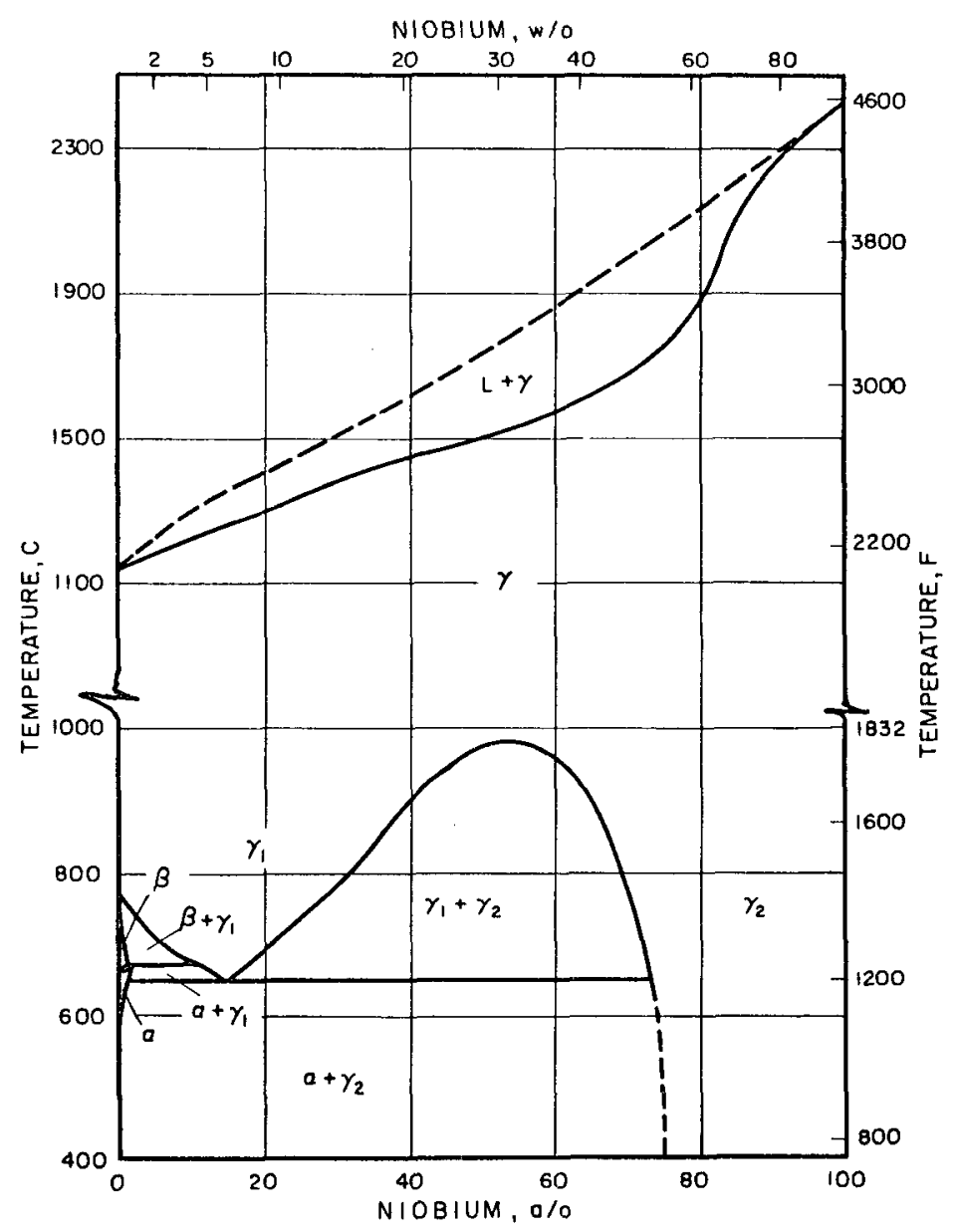

The Constitutional Diagram

The diagram shown is from Rogers(1) and Browne(2), and represents essential confirmation of work of earlier investigator $\{3,4\}$, although revisions in certain boundaries have been made.

The complete solubility of gamma uranium and niobium is agreed on by all investigators $(1,2,3,4,5)$, although there is disagreement as to the extent of the gamma 1 -plus-gamma region. Sawyer $(3)$ reports the-region as extending from about 11 to 78 a/o at $645 \mathrm{C}$, while Rogers $(1)$ and Browne(2) report the monotectoid to occur at $16 \pm 1$ a/o niobium and $645 \mathrm{C}$, but give values of 73 and $70 \mathrm{a} / \mathrm{o}$, respectively, for the niobium-rich limit of the gamma 1 -plus.gamma 2 region at this temperature. Dwight ${ }^{(5)}$ reports the monotectoid as occurring at 19 a/o niobium and $634 \mathrm{C}$, the latter temperature being in agreement with its determination by Bauer ${ }^{(6)}$.

On the basis of a tetragonal structure observed in quenched alloys containing 14 to $20 \mathrm{a} / \mathrm{o}$ niobium and thermal arrests ranging in temperature from 675 to $725 \mathrm{C}$ for alloys containing 9.6 to 17 a/o niobium, Dwight suggests an ordering of the gamma phase in the region of the monotectoid $(5)$. While additional investigation is required, the tetragonal structure may be ascribed to a transition structure in the metastable-gamma decomposition.

There is some question concerning the nature of the alpha-to-beta transformation at the uranium-rich end of the system. Although most investigators $(2,3,5,6)$ agree that the reaction occurs peritectoidally, alpha has also been described as forming in a eutectoid reaction $(1,4)$. A shift of less than $\pm 5 \mathrm{C}$ in the alpha-to-beta transition temperature is agreed to by all investigators.

Solubilities in the alpha and beta phase are reported to be extremely limited. Browne(2) gives the maximum solubility in each phase as being between 1 and 2 a/o niobium. 
Crystallography

There are no compounds in the uranium-niobium system.

References

(1) Rogers, B. A., Atkins, D. F., Manthos, E. J., and Kirkpatrick, M. E., "UraniumColumbium Alloy Diagram", Paper 7, Nuclear Eng. and Sci. Congress (1957).

(2) Browne, J. D., Pfeil, P. C. L., and Williamson, G. K., United Kingdom, unpublished information (1957).

(3) Sawyer, B., "The Uranium-Columbium Alloy System", ANL-4027 (October, 1946).

(4) Saller, H. A., and Rough, F. A., private communication (June, 1952).

(5) Dwight, A. E., and Mueller, M. H., "Constitution of Uranium-Rich Uranium-Niobium and Uranium-Niobium-Zirconium Systems", ANL-5581 (October, 1957).

(6) Bauer, A. A., private communication (1957).

\section{URANIUM-NITROGEN}

Although no diagram has been constructed for the uranium-nitrogen system, considerable information is available. Katz and Rabinowitch $(1)$ have surveyed the work on the system and report the existence of three compounds, $U N, U_{2} N_{3}$, and $U N_{2}$. The system is two phase between the mononitride, $\mathrm{UN}$, and the sesquinitride, $\mathrm{U}_{2} \mathrm{~N}_{3}$. Continuous solubility has been proposed between $\mathrm{U}_{2} \mathrm{~N}_{3}$ and $\mathrm{UN}_{2}$, since the $\mathrm{U}_{2} \mathrm{~N}_{3}$ lattice is a distorted-fluorite structure, and the $U N_{2}$ lattice is a fluorite-type structure. (2) This is questioned by work of Vaughan $(3)^{2}$ who reports that $\mathrm{U}_{2} \mathrm{~N}_{3}$ has a hexagonal structure. The structures are discussed in detail in the section on crystallography below.

The mononitride, UN, melts at about $2630 \pm 50 \mathrm{C} .{ }^{(4)}$ It is quite stable in vacuum at $1700 \mathrm{C}$, and sinters at $2300 \mathrm{C}$. (1)

The sesquinitride, $\mathrm{U}_{2} \mathrm{~N}_{3}$, loses nitrogen in vacuum at temperatures above 700 to $800 \mathrm{C}$. It is stable only to $1300 \mathrm{C}$, where it decomposes to form UN plus $\mathrm{N}_{2}$ at low pressures. (1) Under high pressures, $\mathrm{U}_{2} \mathrm{~N}_{3}$ decomposes to UN plus $\mathrm{UN}_{2}$ at about $1300 \mathrm{C}$, with a volume decrease of about 13 per cent. (2)

The solubility of nitrogen in uranium is limited. The solubility of uranium in the mononitride, UN, is also limited. (1)

Early reports of $\mathrm{U}_{4} \mathrm{~N}_{7}$ seem to be attributable to the observation that the U-plus- $\mathrm{N}_{2}$ reaction at 1 -atm pressure reaches a maximum composition of $\mathrm{UN}_{1} .75$. (2)

\section{Crystallography}

The tabulated lattice constants and data for $U N, U_{2} N_{3}$, and $U_{2}$ are from the work of Rundle (2). The lattice constant of UN has varied as much as $4.899 \mathrm{~A}$. This extreme variation is attributed to the presence of carbon or oxygen instead of solubility of nitrogen in UN. It is very difficult to avoid small amounts of the se contaminants during preparation. (2)

As the nitrogen-to-oxygen ratio is increased from 1.5 to 1.75 , the $\mathrm{U}_{2} \mathrm{~N}_{3}$ lattice constant decreases from 10.678 to $10.580 \mathrm{~A}$; from 1.75 to 2.00 it increases from 10.580 to $10.62(2 \times$ 5.31) A. The decrease is interpreted to mean that there is solubility over the entire range between the distorted-fluorite structure of $U_{2} N_{3}$ and the fluorite structure of $U_{2}$. (2)

Vaughan (3), on the other hand, reports that $U_{2} \mathrm{~N}_{3}$ has a hexagonal lattice with a $=3.70$ and $\mathrm{c}=5.80 \mathrm{~A}$. This structure appears to be consistent with the structure of $\mathrm{Th}_{2} \mathrm{~N}_{3}$, which is hexagonal with $\mathrm{a}=3.87$ and $\mathrm{c}=6.16 \mathrm{~A}$. 


\begin{tabular}{|c|c|c|c|c|c|c|c|}
\hline \multirow[b]{2}{*}{ Phase } & \multicolumn{3}{|c|}{ Unit Cell } & \multirow{2}{*}{\multicolumn{2}{|c|}{ Density, $\mathrm{g} / \mathrm{cm}^{3}$}} & \multirow[b]{2}{*}{$\begin{array}{l}\text { Space } \\
\text { Group }\end{array}$} & \multirow[b]{2}{*}{ Remarks } \\
\hline & Type & $\begin{array}{c}\text { Dimensions, } \\
\mathrm{A} \\
\end{array}$ & $\begin{array}{c}\text { Number } \\
\text { of } \\
\text { Molecules } \\
\end{array}$ & & & & \\
\hline UN & $\mathrm{Fcc}$ & $\begin{aligned} a= & 4.880 \pm \\
& 0.001\end{aligned}$ & 4 & 14.32 & & & $\begin{array}{l}\mathrm{NaCl} \text { structure, } \\
\text { completely solu- } \\
\text { ble with UC }\end{array}$ \\
\hline $\mathrm{U}_{2} \mathrm{~N}_{3}$ & $\mathrm{Bcc}$ & $\begin{array}{c}a=10.678 \pm \\
0.005\end{array}$ & 16 & 11.24 & & Ia 3 & $\begin{array}{l}\text { Distorted-fluorite } \\
\text { structure, iso- } \\
\text { morphous with } \\
\mathrm{Mn}_{2} \mathrm{O}_{3}\end{array}$ \\
\hline $\mathrm{UN}_{2}$ & Pseudo-fcc & $a=5.31$ & & 11.73 & & & Fluorite structure \\
\hline
\end{tabular}

\section{References}

(1) Katz, J. S., and Rabinowitch, Eugene, The Chemistry of Uranium, Part I, McGraw-Hill Book Company, Inc., New York (1951), 232-241.

(2) Rundle, R. E., Baenziger, N. C., Wilson, A. S., and McDonald, R. A., "The Structures of the Carbides, Nitrides and Oxides of Uranium", J. Am. Chem. Soc., 70, 99-105 (1948).

(3) Vaughan, D. A., and Schwartz, C. M., unpublished information (April, 1954).

(4) Chiotti, Premo, "Experimental Refractory Bodies of High-Melting Nitrides, Carbides and Uranium Dioxide", J. Am. Ceram. Soc., 35, 123-30 (May, 1952).

(5) Brewer, Leo, Bromley, L., Gilles, P. W., and Lofgren, N. L., "The Thermodynamic Properties and Equilibrium at High Temperatures of Uraniun Halides, Oxides, Nitrides and Carbides", MDDC-1543, 85 (September, 1945).

\section{URANIUM-OSMIUM}

A partial diagram has been constructed by Park(1), although features in the system are tentative.

Apparently, a minimum of two compounds exists in the system. The first uraniumrich compound decomposes peritectically at a temperature below that of the eutectic temperature. (1) A second compound has been identified as UOs 2 . (2) Osmium is reported to stabilize the gamma and beta phases. (1)

\section{Crystallography}

Data are available for only one compound $\operatorname{UOs}_{2} \cdot(2)$

\begin{tabular}{|c|c|c|c|c|c|c|c|}
\hline \multirow[b]{3}{*}{ Phase } & \multicolumn{3}{|c|}{ Unit Cell } & \multirow{2}{*}{\multicolumn{2}{|c|}{$\begin{array}{c}\text { Density, } \\
\mathrm{g} / \mathrm{cm}^{3} \\
\end{array}$}} & \multirow{3}{*}{$\begin{array}{l}\text { Space } \\
\text { Group }\end{array}$} & \multirow[b]{3}{*}{ Remarks } \\
\hline & \multirow[b]{2}{*}{ Type } & \multirow{2}{*}{$\begin{array}{c}\text { Dimensions, } \\
\mathrm{A} \\
\end{array}$} & \multirow{2}{*}{$\begin{array}{c}\text { Number } \\
\text { of } \\
\text { Molecules }\end{array}$} & & & & \\
\hline & & & & X-Ray & Other & & \\
\hline $\mathrm{UOs}_{2}$ & $F c c$ & $\begin{array}{l}7.5125 \pm \\
0.0005\end{array}$ & 8 & 19.42 & -- & $F d 3 m$ & $\begin{array}{l}\mathrm{C} 15, \mathrm{MgCu}_{2} \\
\text { structure }\end{array}$ \\
\hline
\end{tabular}

References

(1) Park, J. J., private comminnication (October, 1956).

(2) Heal, T. J., and Williams, G. I., "Compounds of Uranium.With Transition Metals of the Second and Third Long Periods", Acta Cryst., 8, 494 (1955). 


\section{URANIUM-OXYGEN}

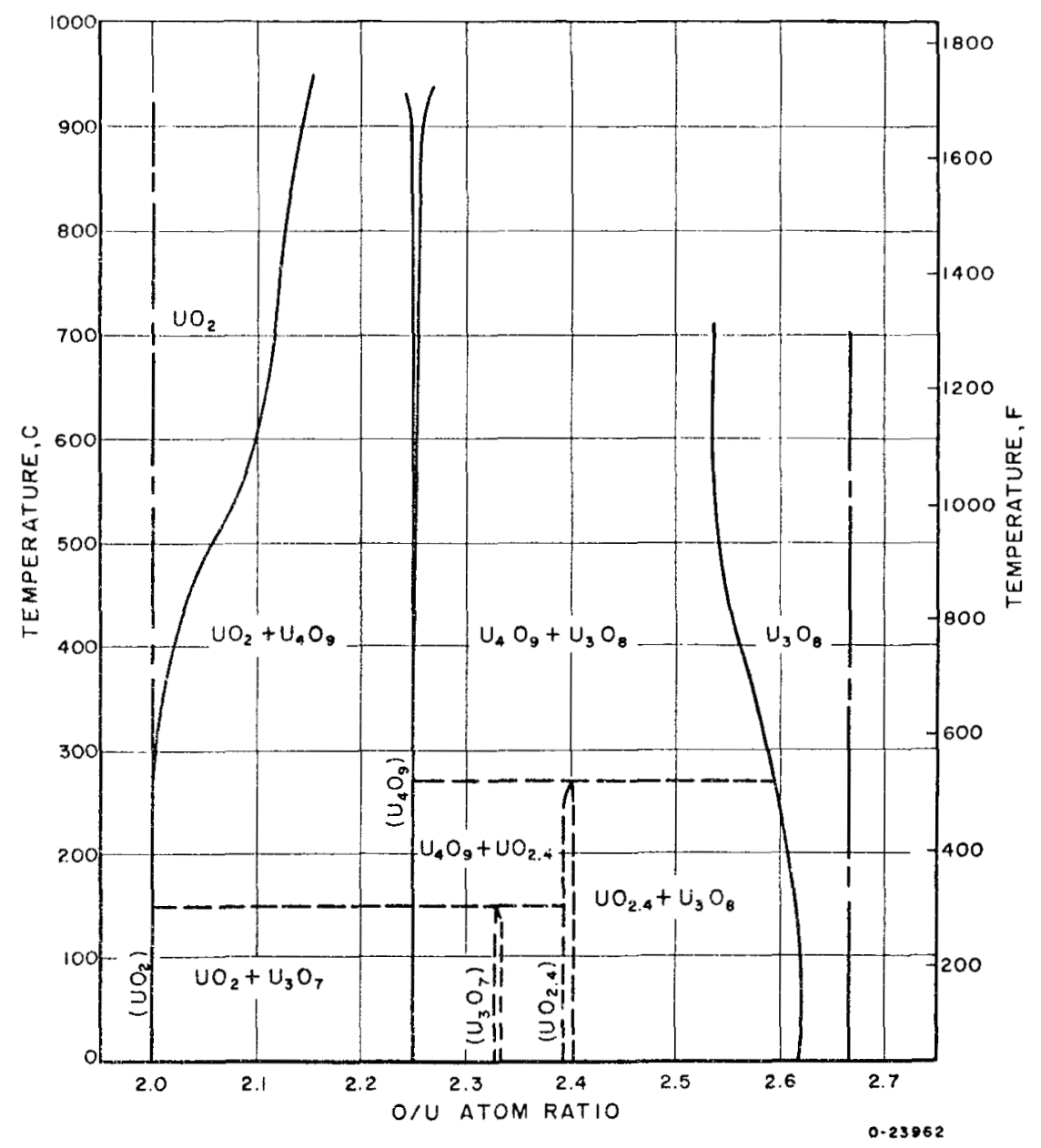

\section{The Constitutional Diagram}

Although much work has been done on the system, the constitution of uranium-oxygen alloys is somewhat uncertain. Katz and Rabinowitch(I) reviewed the system in considerable detail, but were unable to resolve all of the areas of conflicting information. Apparently, experimental results and interpretation are highly dependent upon the starting materials and method of specimen preparation.

The solubility of oxygen in uranium is small even in the liquid state. Cleaves(2) observed solubilities of about 0.05 a/o oxygen at the melting point of uranium and about $0.1 \mathrm{a} / 0$ and $0.4 \mathrm{a} / \mathrm{o}$ oxygen at 1400 and $2000 \mathrm{C}$, respectively.

The solubility in solid uranium is even less; it is difficult to determine exactly because of the presence of other minor impurities (3).

The region between $\mathrm{UO}_{2}$ and $\mathrm{U}_{3} \mathrm{O}_{8}$ has been studied more intensively than any other portion of the system. The diagram shown for this region is from Gronvold(4) and is similar to the diagram published by Perio(5) with the major refinement being that Gronvold shows a solid solution range of oxygen in $\mathrm{UO}_{2}$ at elevated temperatures. Vaughan and Schwartz(6) and Willardson(7) report a wider solubility range both at room and elevated temperatures; at room temperature the range is reported as $\mathrm{UO}_{2}$ to about $\mathrm{UO}_{2}, 10$.

There appears to be fairly general agreement on the existence of three stable uranium oxides in the range shown: (1) the fluorite-type dioxide $\left(\mathrm{UO}_{2}\right)$; (2) the oxide $\mathrm{U}_{4} \mathrm{O}_{9}$ (also reported as beta $\mathrm{UO}_{2}$ ), which maintains the fluorite structure with the apparent addition of an interstitial oxygen atom; and (3) the orthorhombic oxide $\left(\mathrm{U}_{3} \mathrm{O}_{8}\right)$. 
One or more tetragonal oxides form in the region from $\mathrm{UO}_{2} .30$ to $\mathrm{UO}_{2.40}$. However, the stability of these phases appears to be questionable. The phase relationships shown with respect to these oxides are based upon the examination of specimens prepared by the low temperature oxidation of $\mathrm{UO}_{2}$ as reported by Gronvold and Haraldsen(8). Perio(5) and Vaughan and Schwartz $(6)$ report similar results when essentially the same techniques are employed. Although Hering and Perio(9) have reported the reversible formation of $\mathrm{UO}_{2}, 40$ from $\mathrm{UO}_{2}$ and $\mathrm{U}_{3} \mathrm{O}_{8}$, when specimens are homogenized at elevated temperatures the tetragonal oxides apparently do not form on succeeding prolonged low-temperature anneals $(4,5,6,10)$. On this basis it appears that the phase relationships shown by the dotted lines, which were drawn by Gronvold to indicate the temperature at which transformation takes place at an appreciable rate, may represent metastable nonequilibrium conditions. At any rate, there is agreement that the tetragonal oxides decompose to $\mathrm{U}_{4} \mathrm{O}_{9}$ and $\mathrm{U}_{3} \mathrm{O}_{8}$ on heating at elevated temperatures. However, there is some variation in the temperature reported for this decomposition. Alberman and Anderson(10) report the decomposition as occurring above $230 \mathrm{C}$, Gronvold and Haraldsen(8) above $270 \mathrm{C}$, and Perio(9) at 480 to $500 \mathrm{C}$. Vaughan and Schwartz $(6)$ and Willardson $(7)$ are in general agreement with Perio on this point.

Since the tetragonal phase exists over a limited temperature range, there is no conflict with data of Biltz and Muller(11), who determined by tensiometric studies that a twophase region exists at $1200 \mathrm{C}$ between $\mathrm{UO}_{2,31}$ and $\mathrm{UO}_{2.61}$. Hoekstra and Siegel(12) have confirmed the se phase limits and give $\mathrm{UO}_{2} .60$ as the lower limit of $\mathrm{U}_{3} \mathrm{O}_{8}$. Baenziger(13) and Rundle $(14)$ on the other hand report the existence of $\mathrm{U}_{2} \mathrm{O}_{5}$ (composition $\mathrm{UO}_{2}, 50$ ), which seems to be generally interpreted as being the same structure as $\mathrm{U}_{3} \mathrm{O}_{8}(1,9,10,12)^{\circ}$.

The upper limit of $\mathrm{U}_{3} \mathrm{O}_{8}$ is in question. Hering and Perio(9) report a definite limit at 2.67. On the other hand, $\mathrm{Katz}$ and Rabinowitch(1) report that the similarity of the $\mathrm{U}_{3} \mathrm{O}_{8}$ and one of the $\mathrm{UO}_{3}$ structures makes a gradual and continuous transition between the two both possible and plausible.

In addition to the oxides shown in the region from $\mathrm{UO}_{2}$ to $\mathrm{U}_{3} \mathrm{O}_{8}$, the sodium chloridetype monoxide (UO) and the trioxide $\left(\mathrm{UO}_{3}\right)$, with three allotropic modifications $(1)$ have been reported.

The melting point of $\mathrm{UO}_{2}$ is about $2875 \mathrm{C}(15)$.

\section{Crystallography}

The monoxide (UO) has the sodium chloride-type structure. There appears to be limited solubility of oxygen in UO, and the lattice constant does not vary greatly. The tabulated data for UO are from the works of Rundle(14). However, there is some question about the stability of the UO phase. UO, UN, and UC are reported to be isomorphous(12), and on the basis of the inability $(6)$ to prepare an extremely pure sample of UO, this phase may represent a solution of oxygen in the nitride or carbide lattice.

Uranium dioxide is cubic and has the fluorite-type structure. The data for $\mathrm{UO}_{2}$ are also from Rundle. Numerous data on $\mathrm{UO}_{2}$ are summarized by Katz and Rabinowitch(1) that show a variety of values for the $\mathrm{UO}_{2}$ lattice constant. These generally fall within the lattice constants given by Rundle, who reports that the $\mathrm{UO}_{2}$ lattice can be increased to a $=5.4720 \pm$ $0.0007 \mathrm{~A}$ by heating $\mathrm{UO}_{2}$ with uranium. Similarly, it can be decreased to $a=5.4407 \pm$ $0.0008 \mathrm{~A}$ by increasing the oxygen content.

The data for the $U_{4} \mathrm{O}_{9}$ phase are from Gronvold(4). The high density, $11.159 \mathrm{~g} / \mathrm{cm}^{3}$, is taken as evidence of the interstitial solubility of oxygen in the fluorite $\mathrm{UO}_{2}$-like structure.

It is difficult to determine whether a single phase with a wide solubility range or whether more than one tetragonal phase exists in the region $\mathrm{UO}_{2}, 30$ to $\mathrm{UO}_{2}, 40$. Diffusion is very slow at the temperatures at which the se phases form, and it is questionable whether equilibrium is attained. The tabulated data for the $\mathrm{U}_{3} \mathrm{O}_{7}$ phase are from Perio(5). The tetragonal oxides are apparently characterized by an increase in the c/a ratio with increasing oxygen content.

The oxide $\mathrm{U}_{2} \mathrm{O}_{5}(13,14)$ is reported to have an orthorhombic structure with $\mathrm{a}=6.73 \pm$ $0.02 \mathrm{~A}, \mathrm{~b}=31.71 \pm 0.1 \mathrm{~A}$, and $\mathrm{c}=8.29 \pm 0.02 \mathrm{~A}$. This structure contains a pseudo cell with $\mathrm{a}=6.73 \mathrm{~A}, \mathrm{~b}=3.964 \mathrm{~A}$, and $\mathrm{c}=4.145 \mathrm{~A}$, which is closely related to the structure of $\mathrm{U}_{3} \mathrm{O}_{8}$ (tabulated) as reported by Zachariasen. The pseudo cell is identical with the $\mathrm{U}_{3} \mathrm{O}_{8}$ structure as reported by Gronvold $(8)$. For that matter, Rundle reports a single-phase region between $\mathrm{U}_{2} \mathrm{O}_{5}$ and $\mathrm{U}_{3} \mathrm{O}_{8}{ }^{(14)}$. It appears that the varying reports all concern a continuous series of solid solutions. 
$X$-ray data for two of the three trioxide $\left(\mathrm{UO}_{3}\right)$ modifications reported(l) are tabulated. "Alpha" $\mathrm{UO}_{3}$, tabulated as hexagonal, was reported by Zachariasen(16), and is orange. It was formed by reacting amorphous $\mathrm{UO}_{3}$ at $500 \mathrm{C}$ for $8 \mathrm{hr}$ under $20 \mathrm{~atm}$ of oxygen pressure. The "beta" $\mathrm{UO}_{3}$, tabulated as orthorhombic, was reported by Perio(17). It is yellow and was formed by heating amorphous $\mathrm{UO}_{3}$ in sealed tubes at about 600 to $620 \mathrm{C}$. Under these same test conditions, $\mathrm{UO}_{3}$ decomposed at 610 to $740 \mathrm{C}$ to form the orthorhombic $\mathrm{U}_{3} \mathrm{O}_{8}(17)$.

Additional references are included $(18,19,20,21)$.

No anhydrous higher oxides appear to be stable(1)

\begin{tabular}{|c|c|c|c|c|c|c|c|}
\hline \multirow[b]{3}{*}{ Phase } & \multicolumn{3}{|c|}{ Unit Cell } & \multirow{2}{*}{\multicolumn{2}{|c|}{$\begin{array}{c}\text { Density. } \\
\text { g/ } \mathrm{cm}^{3}\end{array}$}} & \multirow{3}{*}{$\begin{array}{l}\text { Space } \\
\text { Group }\end{array}$} & \multirow[b]{3}{*}{ Remarks } \\
\hline & \multirow[b]{2}{*}{ Type } & \multirow{2}{*}{$\begin{array}{c}\text { Dimensions, } \\
\text { A }\end{array}$} & \multirow{2}{*}{$\begin{array}{c}\text { Number } \\
\text { of } \\
\text { Molecules }\end{array}$} & & & & \\
\hline & & & & X-Ray & Other & & \\
\hline UO & $F \subset c$ & $a=4.92$ & 4 & 13.63 & & & $\begin{array}{l}\text { NaCl structure } \\
\text { isomorphous } \\
\text { with UO and } \\
\text { UN }\end{array}$ \\
\hline $\mathrm{UO}_{2}$ & Cubic & $a=5.4691 \cdot 0.0005$ & 4 & 10.96 & & & $\begin{array}{l}\text { Fluorite-type } \\
\text { structure iso- } \\
\text { morphous with } \\
\mathrm{ThO}_{2}\end{array}$ \\
\hline $\mathrm{U}_{4} \mathrm{O}_{9}$. & Cubic & $a=5.4411$ & & & 11.159 & & \\
\hline $\mathrm{U}_{3} \mathrm{O}_{7}$ & $\begin{array}{l}\text { Tetrago- } \\
\text { nal }\end{array}$ & $\begin{array}{l}a=5.447 \pm 0.003 \\
c=5.400 \pm 0.002\end{array}$ & & & & & \\
\hline $\mathrm{U}_{3} \mathrm{O}_{8}$ & $\begin{array}{l}\text { Ortho- } \\
\text { rhombic }\end{array}$ & $\begin{array}{l}a=6.71 \pm 0.01 \\
b=11.96 \pm 0.03 \\
c=4.15 \pm 0.01\end{array}$ & 2 & & & $\mathrm{Amm}$ & \\
\hline $\begin{array}{l}\text { "Alpha" } \\
\mathrm{UO}_{3}\end{array}$ & $\begin{array}{l}\text { Hexago- } \\
\text { nal }\end{array}$ & $\begin{array}{l}a=3.971 \pm 0.004 \\
c=4.168 \pm 0.008\end{array}$ & l & 8.39 & 8.34 & $\mathrm{C} \overline{3} \mathrm{~m}$ & $\begin{array}{l}\text { Similar to } \\
\text { orthorhombic } \\
\mathrm{U}_{3} \mathrm{O}_{8}\end{array}$ \\
\hline $\begin{array}{c}\text { "Beta" } \\
\mathrm{UO}_{3}\end{array}$ & $\begin{array}{l}\text { Ortho- } \\
\text { rhombic }\end{array}$ & $\begin{array}{l}a=13.01 \\
b=10.72 \\
c=7.51\end{array}$ & 16 & & 7.15 & & \\
\hline
\end{tabular}

References

(1) Katz, J. J., and Rabinowitch, E., The Chemistry of Uranium, Part I, McGraw-Hill Book Company, Inc., New York (1951), pp 224-281.

(2) Cleaves, H. E., Cron, M. M., and Sterling, J. T., unpublished information (February, 1954).

(3) Blumenthal, B., unpublished information (1952).

(4) Gronvold, F., J. Inorg. and Nuclear Chem., 1, 357 (1955).

(5) Perio, P., "Low Temperature Oxidation of $\mathrm{UO}_{2}$ ", Bull. soc. chim. France, pp 256-263 (1953).

(6) Vaughan, D. A., Bridge, J. R., and Schwartz, C. M., "Comparison of Active and Inactive Uranium Dioxide-Oxygen Systems", BMI-1241 (December 10, 1957).

(7) Willardson, R. K., Moody, J. W., and Goering, H. L., "The Electrical Properties of Uranium Oxides", BMI-1135 (September 25, 1956).

(8) Gronvold, F., and Haraldsen, H., "Crystal Structure of Uranium Oxide $\left(\mathrm{U}_{3} \mathrm{O}_{8}\right)$ ", Nature, 162, 69-70 (1948). 
(9) Hering, H. , and Perio, P., "Equilibria of Uranium Oxides Between $\mathrm{UO}_{2}$ and $\mathrm{U}_{3} \mathrm{O}_{8}$ ", Bull. soc. chim. France, pp 351-7 (March-April, 1952).

(10) Alberman, K. B., and Anderson, J. S., "The Oxides of Uranium", J. Am. Chem. Soc., 2 (Supplementary Is sue), S 303-11 (1949).

(11) Biltz, W., and Muller, H., Z. anorg. u. allgem, chem., 163, 161-295 (1927).

(12) Hoekstra, H., and Siegel, S., unpublished information (September, 1952).

(13) Baenziger, N. C., "The Crystal Structure of Some Thorium and Uranium Compounds", AECO-3237 (1948).

(14) Rundle, R. E., Baenziger, N. C., Wilson, A. S., and McDonald, R. A., "The Structures of the Carbides, Nitrides, and Oxides of Uranium" (MDDC-1608), J. Am. Chem. Soc., 70, 99-105 (1948).

(15) Brewer, L., Bromley, L., Gilles, P. W., and Lofgren, N. L., "The Thermodynamic Properties and Equilibrium at High Temperatures of Uranium Hydrides, Oxides, Nitrides, and Carbides", MDDC-1543, 85 (September 20, 1945).

(16) Zachariasen, W. H., "Crystal Chemical Studies of the 5 F-Series of Elements", Acta. Cryst., 1, 265 (1948).

(17) Perio, P., "Crystalline Varieties of UO 3 ", Bull soc. chim. France, 776-7 (JulyAugust, 1953).

(18) Hoekstra, H. R., and Katz, J. J., "Studies on the Uranium-Oxygen System", AECD2954, 15 (August 10, 1950).

(19) Slowinski, E., and Elliot, N., "Lattice Constants and Magnetic Susceptibilities of Solid Solutions of Uranium and Thorium Dioxides", Acta Cryst., 5, 768-770 (1952).

(20) Lambertson, W. A., Mueller, M. H., and Gunzel, F. H., Jr., "Uranium Oxide Phase Equilibrium Systems", J. Am. Ceram. Soc., 36, 329-334, 398-399 (1953).

(21) Perio, P. , "Observation on Uranium Oxides Formed Between $\mathrm{UO}_{2}$ and $\mathrm{U}_{3} \mathrm{O}_{8}$ ", Bull. soc. chim. France, 840-841 (1953). 


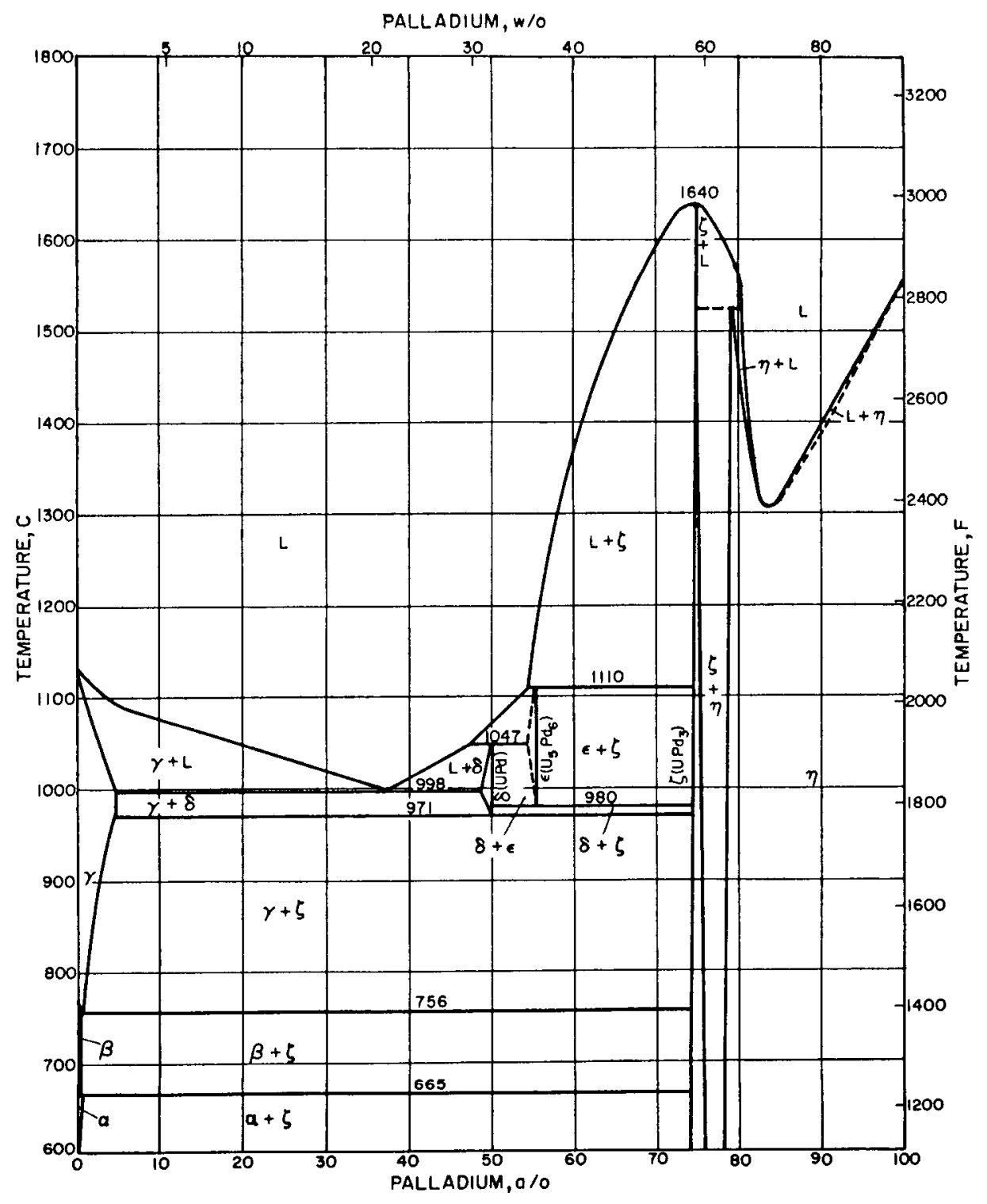

The Constitutional Diagram

The diagram shown is that of Catterall, Grogan, and Pleasance(1); it differs in many respects from the tentative diagram of $\mathrm{Park}(2)$. The latter reported two compounds, $\mathrm{UPd}_{2}$ and $\mathrm{U}_{3} \mathrm{Pd}_{7}$, stable to room temperature in addition to the congruently melting $\mathrm{UPd}_{3}$.

The solubility of palladium in uranium is small, being less than $0.3 \mathrm{a} / 0$ in both the alpha and beta phases.(1) Solubility in the gamma phase is greater, rising from less than 1.1 a $/ 0$ at $760 \mathrm{C}$ to $5 \mathrm{a} / \mathrm{o}$ at $998 \mathrm{C}$ according to Catterall $(1)$. The se values are in good agreement with those reported by Park(2) of about 4 a /o at $995 \mathrm{C}$.

The temperature of the peritectoid by which the palladium solid solution forms has not been located exactly, although it exceeds $1425 \mathrm{C}$ and is tentatively estimated to occur at $1525 \mathrm{C}$. Uranium has a large solubility in palladium; Catterall(1) quotes solubilities of 22.2 a/o at 700 , 800 , and $900 \mathrm{C} ; 21.9 \mathrm{a} / 0$ at $1180 \mathrm{C}$, and 21.8 a $/ 0$ at $1400 \mathrm{C}$. 


\section{Crystallography}

The structure of $\mathrm{UPd}_{3}$ has been reported by Heal and Williams ${ }^{(3)}$ and confirmed by Catterall(1), who also reported a variation in the lattice parameters with composition; thus, a uranium rich sample gave $c=9.641 \mathrm{~A}, a=5.769 \mathrm{~A}$, and $\mathrm{c} / \mathrm{a}=1.671$, whereas a palladiumrich sample gave $\mathrm{c}=9.526 \mathrm{~A}, \mathrm{a}=5.763 \mathrm{~A}$, and $\mathrm{c} / \mathrm{a}=1.653$.

\begin{tabular}{|c|c|c|c|c|c|c|c|}
\hline \multirow[b]{3}{*}{ Phase } & \multicolumn{3}{|c|}{ Unit Cell } & \multirow{2}{*}{\multicolumn{2}{|c|}{$\begin{array}{c}\text { Density, } \\
\mathrm{g} / \mathrm{cm}^{3} \\
\end{array}$}} & \multirow{3}{*}{$\begin{array}{l}\text { Space } \\
\text { Group }\end{array}$} & \multirow[b]{3}{*}{ Remarks } \\
\hline & & Dimensions, & $\begin{array}{c}\text { Number } \\
\text { of }\end{array}$ & & & & \\
\hline & Type & $\mathrm{A}$ & Molecules & X-Ray & Other & & \\
\hline $\mathrm{UPd}_{3}$ & Hexagonal & $\begin{array}{l}a=5.769 \\
c=9.640\end{array}$ & 4 & 13.39 & & $\mathrm{P} 63 / \mathrm{mmc}$ & $\begin{array}{l}\mathrm{DO} 24, \mathrm{TiNi}_{3} \\
\text { structure }\end{array}$ \\
\hline
\end{tabular}

\section{References}

(1) Catterall, J. A., Grogan, J. D., and Pleasance, R. J., "The System UraniumPalladium", J. Inst. Met., 85, 63 (1956-1957).

(2) Park, J. J., private communication (October, 1956).

(3) Heal, 'T. J., and Williams, G. I., "Compounds of Uranium with the Transition Metals of the Second and Third Long Periods", Acta Cryst., 8, 494 (1955).

\section{URANIUM-PHOSPHORUS} available.

Several uranium-phosphorus compounds have been reported. No other information is Crystallography

The reported structures of $\mathrm{UP}^{(1,2)}, \mathrm{U}_{3} \mathrm{P}_{4}(2)$, and $\mathrm{UP}_{2}{ }^{(3)}$ are tabulated below. Additional references are given. $(4,5)$

\begin{tabular}{|c|c|c|c|c|}
\hline \multirow[b]{2}{*}{ Phase } & \multicolumn{3}{|c|}{ Unit Cell } & \multirow[b]{2}{*}{ Remarks } \\
\hline & Type & $\begin{array}{c}\text { Dimensions, } \\
\mathrm{A} \\
\end{array}$ & $\begin{array}{c}\begin{array}{c}\text { Number } \\
\text { of }\end{array} \\
\text { Molecules } \\
\end{array}$ & \\
\hline UP & $\mathrm{Fcc}$ & $a=5.589$ & 4 & $\mathrm{NaCl}$-type structure \\
\hline $\mathrm{U}_{3} \mathrm{P}_{4}$ & $\mathrm{Bcc}$ & $a=8.197$ & 4 & Analogous to $\mathrm{Th}_{3} \mathrm{P}_{4}$ \\
\hline $\mathrm{UP}_{2}$ & Tetragonal & $\begin{array}{l}a=3.800 \\
c=7.762\end{array}$ & & Isomorphous with UAs ${ }_{2}$ \\
\hline
\end{tabular}

\section{References}

(1) Rundle, R. E., and Baenziger, N. C., unpublished information (1944).

(2) Zumbusch, M., "Structural Analogy of Uranium and Thorium Phosphides", Z. anorg. u. allgem. Chem., 245, 402-8 (1941).

(3) Iandelli, A., "Uranium Arsenides, II: Crystal Structure of UAs 2 and UP 2 ", Atti accad. nazl. Lincei, Rend., Classe sci. fis., mat. e nat., 13, 144-51 (1952).

(4) Heinbrecht, M., Zumbusch, M., and Biltz, W., "Systematic Study of Affinity, XCV: Uranium Phosphides", Z. anorg. u. allgem. Chem., 245, 391-401 (1941).

(5) Katz, J. J., and Rabinowitch, Eugene, The Chemistry of Uranium, Part I, McGraw-Hill Book Company, Inc., New York (1951), 241 . 


\section{URANIUM-PLATINUM}

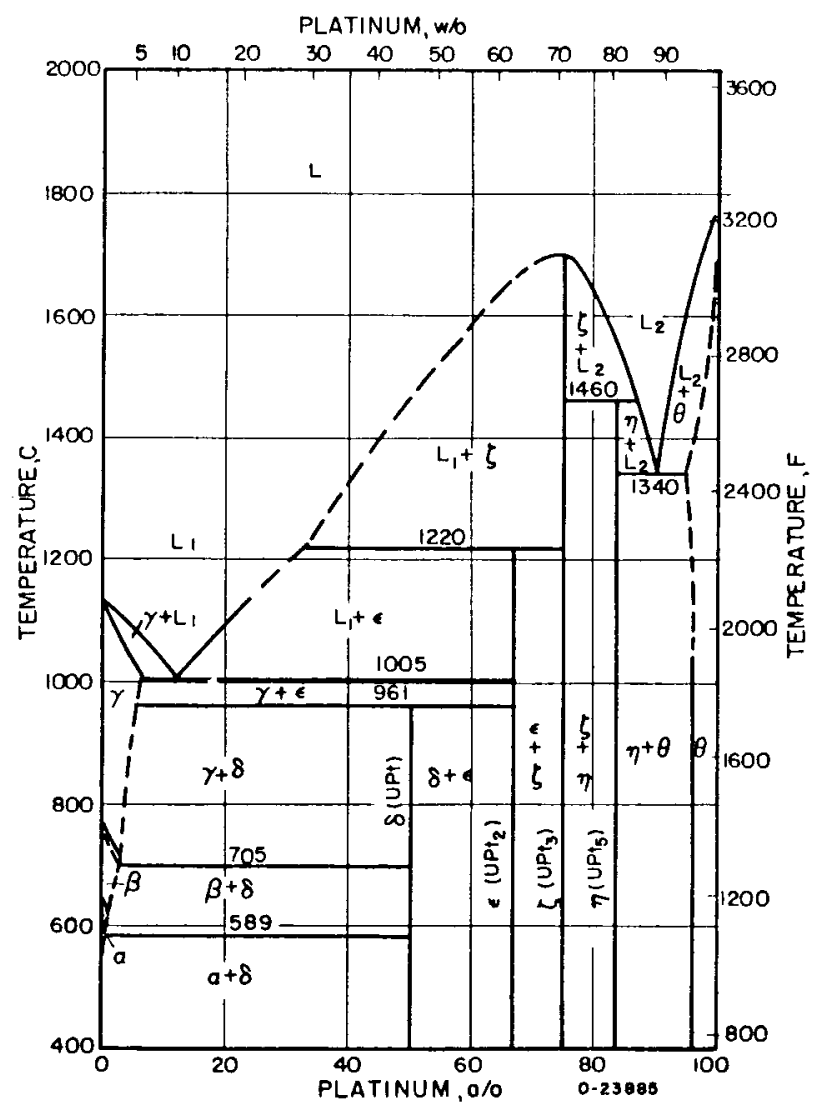

The Constitutional Diagram

The system has been studied by Park(1), and a tentative diagram constructed.

Two eutectics occur in the system, one at 12 a/0 platinum and another at 90 a/0 platinum. Four intermetallic compounds have been identified.

Maximum solubility on the gamma-uranium phase is reported to be 6.5 a /o platinum at the eutectic temperature. (1) Solubilities of about 3.0 and 0.3 a $/ 0$ in the beta- and alphauranium phases, respectively, are indicated.

Approximately 5 a $/ 0$ uranium is soluble in platinum.

\section{Crystallography}

The crystal structures of $\mathrm{UPt}_{2}{ }^{(2)}$ and $\mathrm{UPt}_{3}{ }^{(3)}$ have been determined.

\begin{tabular}{|c|c|c|c|c|c|c|c|}
\hline \multirow[b]{3}{*}{ Phase } & \multicolumn{3}{|c|}{ Unit Cell } & & & \multirow{3}{*}{$\begin{array}{l}\text { Space } \\
\text { Group }\end{array}$} & \multirow[b]{3}{*}{ Remarks } \\
\hline & \multirow[b]{2}{*}{ Type } & \multirow{2}{*}{$\begin{array}{c}\text { Dimensions, } \\
\mathrm{A} \\
\end{array}$} & \multirow{2}{*}{$\begin{array}{c}\text { Number } \\
\text { of } \\
\text { Molecules }\end{array}$} & \multicolumn{2}{|c|}{$\begin{array}{l}\text { Density, } \\
\mathrm{g} / \mathrm{cm}^{3} \\
\end{array}$} & & \\
\hline & & & & X-Ray & Other & & \\
\hline $\begin{array}{l}\text { Zeta } \\
\left(\mathrm{UPt}_{3}\right)\end{array}$ & $\begin{array}{c}\text { Hexag- } \\
\text { onal }\end{array}$ & $\begin{array}{l}a=5.764 \\
c=4.898\end{array}$ & 2 & 19.40 & & $\mathrm{P}_{3} / \mathrm{mmc}$ & $\begin{array}{l}\mathrm{DO} 19, \mathrm{Mg}_{3} \mathrm{Cd} \\
\text { structure }\end{array}$ \\
\hline $\begin{array}{l}\text { Epsilon } \\
\left(\mathrm{UPt}_{2}\right)\end{array}$ & $\begin{array}{l}\text { Ortho- } \\
\text { rhombic }\end{array}$ & $\begin{array}{l}a=4.12 \\
b=9.69 \\
c=5.64\end{array}$ & 4 & 18.54 & & $\mathrm{Cmcm}$ & \\
\hline
\end{tabular}


(1) Park, J. J., private communication (October, 1956).

(2) Fulmer Research Institute, United Kingdom, unpublished information (June, 1957).

(3) Heal, T. J., and Williams, G. I., "Compounds of Uranium With the Transition Metals of the Second and Third Long Periods", Acta Cryst., 8, 494 (1955).

\section{UR ANIUM-PLUTONIUM}

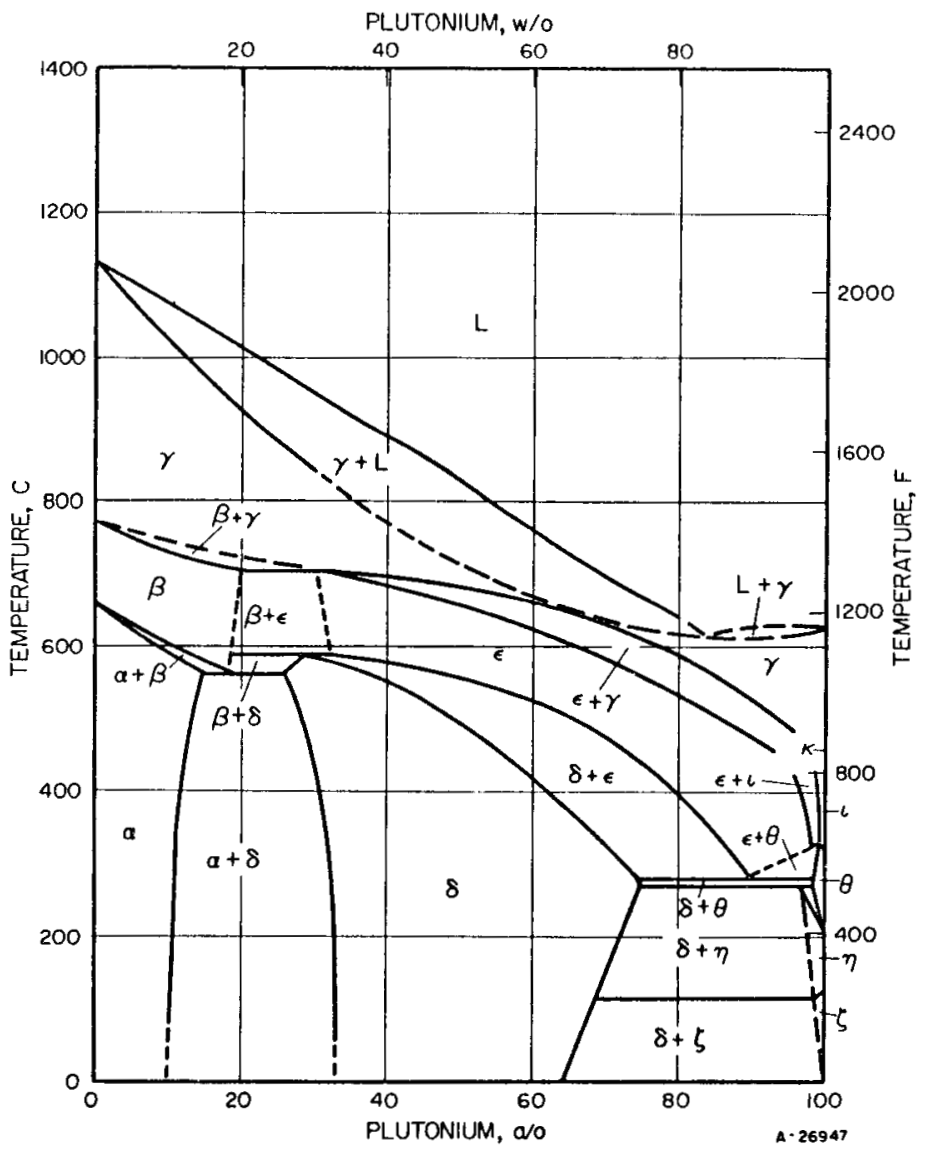

\section{The Constitutional Diagram}

Phase relationships in this system are quite complex but have been well defined. (1) The liquidus in the system exhibits a minimum as shown and at elevated temperatures the bodycentered cubic forms of uranium and plutonium show complete mutual solubility. Two intermediate phases with extensive ranges of homogeneity a re reported. The delta phase extends from 26 to 75 a/o plutonium; the epsilon phase extends from 30 to 98 a/o plutonium.

\section{Crystallography}

Tentative structure identification is given below. (1) Because the epsilon phase is not stable at room temperature, difficulty was found in obtaining good diffraction patterns. The delta phase, while cubic at room temperature, expands anisotropically when heated. The powder pattern splits in accordance with tetragonal symmetry; consequently, the structure given below is for room temperature. 


\begin{tabular}{|c|c|c|c|c|c|c|c|}
\hline \multirow[b]{3}{*}{ Phase } & \multicolumn{3}{|c|}{ Unit Cell } & \multirow{2}{*}{\multicolumn{2}{|c|}{$\begin{array}{l}\text { Density, } \\
\mathrm{g} / \mathrm{cm}^{3}\end{array}$}} & \multirow{3}{*}{$\begin{array}{l}\text { Space } \\
\text { Group }\end{array}$} & \multirow[b]{3}{*}{ Remarks } \\
\hline & \multirow[b]{2}{*}{ Type } & \multirow{2}{*}{$\begin{array}{c}\text { Dimensions, } \\
\mathrm{A} \\
\end{array}$} & \multirow{2}{*}{$\begin{array}{c}\begin{array}{c}\text { Number } \\
\text { of }\end{array} \\
\text { Molecules } \\
\end{array}$} & & & & \\
\hline & & & & X-Ray & Other & & \\
\hline Delta & $\begin{array}{l}\text { Simple } \\
\text { tetrag- } \\
\text { onal }\end{array}$ & $\begin{array}{l}a=10.57 \pm 0.05 \\
c=10.76 \pm 0.05\end{array}$ & 52 & 17.15 & & & $\begin{array}{l}\text { Data for } \mathrm{UPu}_{3} \\
\text { composition }\end{array}$ \\
\hline Epsilon & $\begin{array}{r}\text { Simple } \\
\text { cubic }\end{array}$ & $a=10.664$ & 58 & 18.95 & & & $\begin{array}{l}\text { Data for UPu } \\
\text { composition }\end{array}$ \\
\hline
\end{tabular}

\section{Reference}

(1) Schonfeld, F. W., "Phase Diagram Studies at Los Alamos", ASM Seminar (1957).

\section{URANIUM-PRASEODYMIUM}

Uranium and praseodymium are only partially miscible in the liquid state $(1,2)$. The solubility of praseodymium in uranium is reported as $0.2 \mathrm{w} / 0$ at $1150 \mathrm{C}$ and $0.4 \mathrm{w} / 0$ at $1250 \mathrm{C}$, while the solubility of uranium in praseodymium is given as $1.0 \mathrm{w} / 0$ at $1000 \mathrm{C}$ and $2.2 \mathrm{w} / 0$ at 1250 C. (2)

\section{Crystallography}

Probably there are no compounds in the uranium-praseodymium system.

\section{$\underline{\text { References }}$}

(1) National Physical Laboratory, United Kingdom, unpublished information (1949-1950).

(2) Wilhelm, H. A., "Nuclear Fuels Newsletter", WASH-704 (December, 1957). Classified.

\section{URANIUM-RHENIUM}

While a diagram is not available for the system, a number of observations concerning uranium-rhenium alloys have been reported. (1)

There are apparently two compounds in the system: URe 2 which melts at a temperature in excess of $1200 \mathrm{C}$, and an ordered structure with a limited temperature range of stability containing 8 to 10 a/o rhenium. At $1000 \mathrm{C} \mathrm{URe}_{2}$ exists in equilibrium with gamma uranium which is replaced at $800 \mathrm{C}$ by an optically anisotropic phase with an ordered structure similar to that of $\mathrm{U}_{2} \mathrm{Mo}$. At lower temperatures, beta uranium containing $4 \mathrm{a} / 0$ rhenium was found to decompose eutectoidally at 625 to $630 \mathrm{C}$ to alpha uranium and $\mathrm{URe}_{2}$.

Fairly exten sive solid solubility of rhenium in gamma uranium is indicated, up to 16 a/o rhenium being retained in solid solution in rapidly cooled small melts. Peritectic formation of the gamma phase is probable, a thermal arrest being detected in a 7.5 a $/ 0$ rhenium alloy at a temperature of 1150 to $1200 \mathrm{C}$. The solid-solution region decreases rapidly initially, with about 6 a/o rhenium being soluble in gamma uranium between 800 and $1000 \mathrm{C}$; little variation in solubility with temperature is observed in this range. The solubility of rhenium in alpha uranium is about $1 \mathrm{a} / 0$ at $650 \mathrm{C}$ and decreases to less than $0.5 \mathrm{a} / 0$ at $600 \mathrm{C}$.

The gamma phase can be retained in alloys containing 5 a/o rhenium but decomposition to a distorted alpha structure proceeds at room temperature. The distorted alpha structure is developed on quenching alloys containing 4 a/o rhenium. 


\section{Crystallography}

The compound URe ${ }_{2}$ exhibits two allotropic forms. Above $180 \pm 3 \mathrm{C}$, it has a hexagonal C14-type structure, and below this temperature an orthorhombic structure based on a distorted C14-type structure. The data below are from Hatt(2).

The second compound found in alloys containing about 10 a/o rhenium when quenched from $800 \mathrm{C}$ appears to be similar in structure to $\mathrm{U}_{2} \mathrm{Mo}$ of the uranium molybdenum system. A tentative room-temperature analysis indicates a tetragonal structure with $c / a=0.98$. (1)

\begin{tabular}{|c|c|c|c|c|c|c|c|}
\hline \multirow[b]{3}{*}{ Phase } & \multicolumn{3}{|c|}{ Unit Cell } & & & \multirow{3}{*}{$\begin{array}{l}\text { Space } \\
\text { Group }\end{array}$} & \multirow[b]{3}{*}{ Remarks } \\
\hline & \multirow[b]{2}{*}{ Type } & \multirow{2}{*}{$\begin{array}{c}\text { Dimensions, } \\
\text { A } \\
\end{array}$} & \multirow{2}{*}{$\begin{array}{c}\text { Number } \\
\text { of } \\
\text { Molecules }\end{array}$} & \multicolumn{2}{|c|}{$\begin{array}{c}\text { Density, } \\
\mathrm{g} / \mathrm{cm}^{3}\end{array}$} & & \\
\hline & & & & X-Ray & Other & & \\
\hline $\mathrm{URe}_{2}$ & $\begin{array}{l}\text { Ortho- } \\
\text { rhombic }\end{array}$ & $\begin{array}{l}a=5.600 \\
b=9.178 \\
c=8.463\end{array}$ & 8 & 18.65 & & $\mathrm{Cmcm}$ & $\begin{array}{l}\text { Dimensions for } \\
20 \mathrm{C}\end{array}$ \\
\hline $\mathrm{URe}_{2}$ & $\begin{array}{l}\text { Hexag- } \\
\text { onal }\end{array}$ & $\begin{array}{l}a=5.433 \\
c=8.561\end{array}$ & 4 & 18.56 & & $\mathrm{~Pb}_{3} / \mathrm{mmc}$ & $\begin{array}{l}\text { Cl4 type; dimen- } \\
\text { sions for } 213 \mathrm{C}\end{array}$ \\
\hline
\end{tabular}

\section{References}

(1) Fulmer Research Institute, United Kingdom, unpublished information (June, 1957).

(2) Hatt, B. A., "The Crystal Structure of URe 2 ", Fulmer Research Institute Report, R. $53 / 19(1955)$.

\section{URANIUM-RHODIUM}

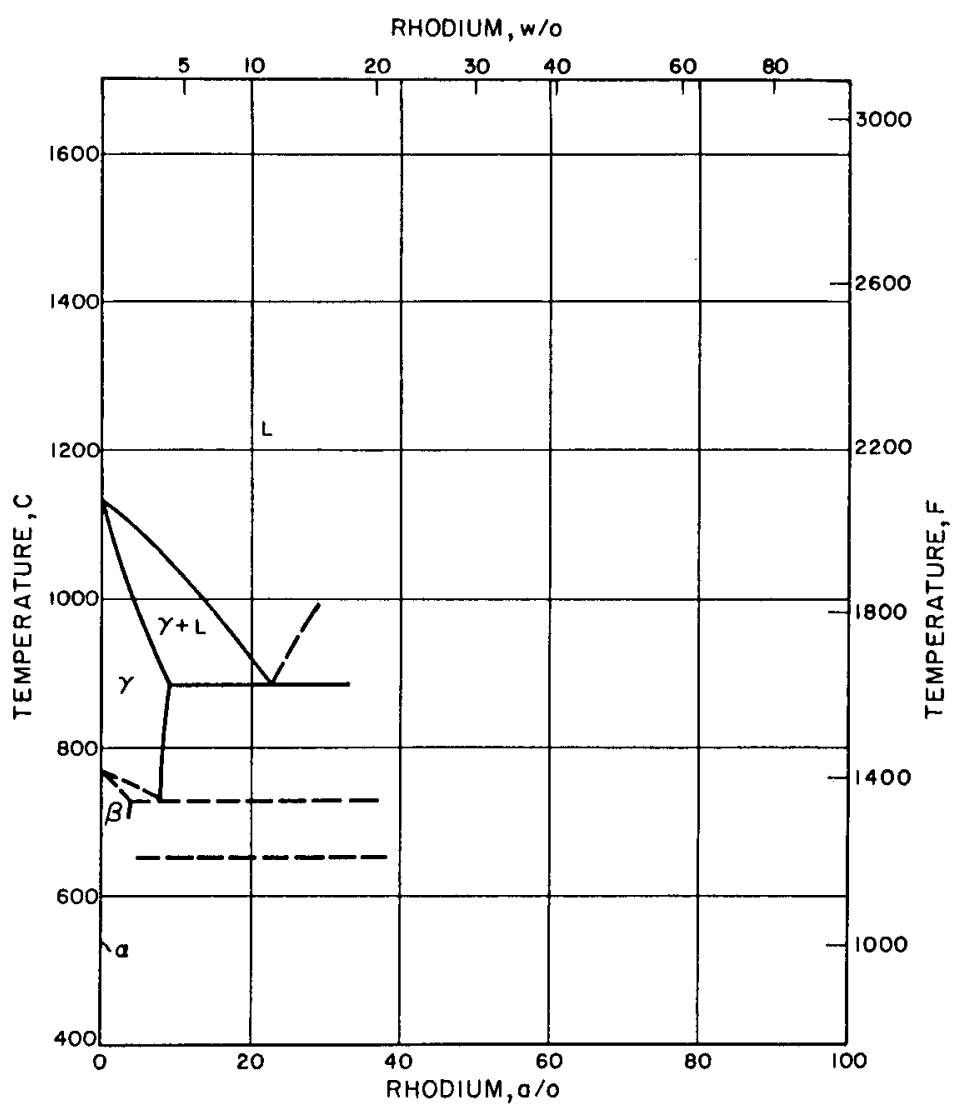




\section{The Constitutional Diagram}

The features shown have been determined by Yorke ${ }^{(1)}$ and are confirmed in form by the work of Park (2). The eutectic occurs at 22.5 a $/ 0$ rhodium and $885 \mathrm{C}$. There is considerable solubility of rhodium in the gamma-uranium phase. Yorke reports solubilities of $9 \pm 1$ a/o at $885 \mathrm{C}$ and $8.5 \pm 1 \mathrm{a} / 0$ at $850 \mathrm{C}$. Park reports the gamma-to-beta transformation is depressed to $730 \mathrm{C}$.

\section{Crystallography}

The crystal structure of $\mathrm{URh}_{3}$ has been determined(3) as below.

\begin{tabular}{|c|c|c|c|c|c|c|c|}
\hline \multirow[b]{3}{*}{ Phase } & \multicolumn{3}{|c|}{ Unit Cell } & \multirow{2}{*}{\multicolumn{2}{|c|}{$\begin{array}{l}\text { Density, } \\
\mathrm{g} / \mathrm{cm}^{3}\end{array}$}} & \multirow{3}{*}{$\begin{array}{l}\text { Space } \\
\text { Group } \\
\end{array}$} & \multirow[b]{3}{*}{ Remarks } \\
\hline & \multirow[b]{2}{*}{ Type } & \multirow{2}{*}{$\begin{array}{c}\text { Dimensions, } \\
\mathrm{A} \\
\end{array}$} & \multirow{2}{*}{$\begin{array}{c}\begin{array}{c}\text { Number } \\
\text { of } \\
\text { Molecules }\end{array} \\
\end{array}$} & & & & \\
\hline & & & & X-Ray & Other & & \\
\hline $\mathrm{URh}_{3}$ & Cubic & $a=3.991$ & 1 & & & $\mathrm{Pm} 3 \mathrm{~m}$ & $\begin{array}{l}\mathrm{LI}_{2}-\mathrm{Cu}_{3} \mathrm{~A} \\
\text { structure }\end{array}$ \\
\hline
\end{tabular}

\section{References}

(1) Yorke, J. M., "Alloys of Uranium With Ruthenium and Rhodium", Johnson and Matthey Ltd. , AERE X/PR 2409 (1956).

(2) Park, J. J., private communication (October, 1956).

(3) Dwight, A. E., private communication (October 28, 1957).

\section{URANIUM-RUTHENIUM}

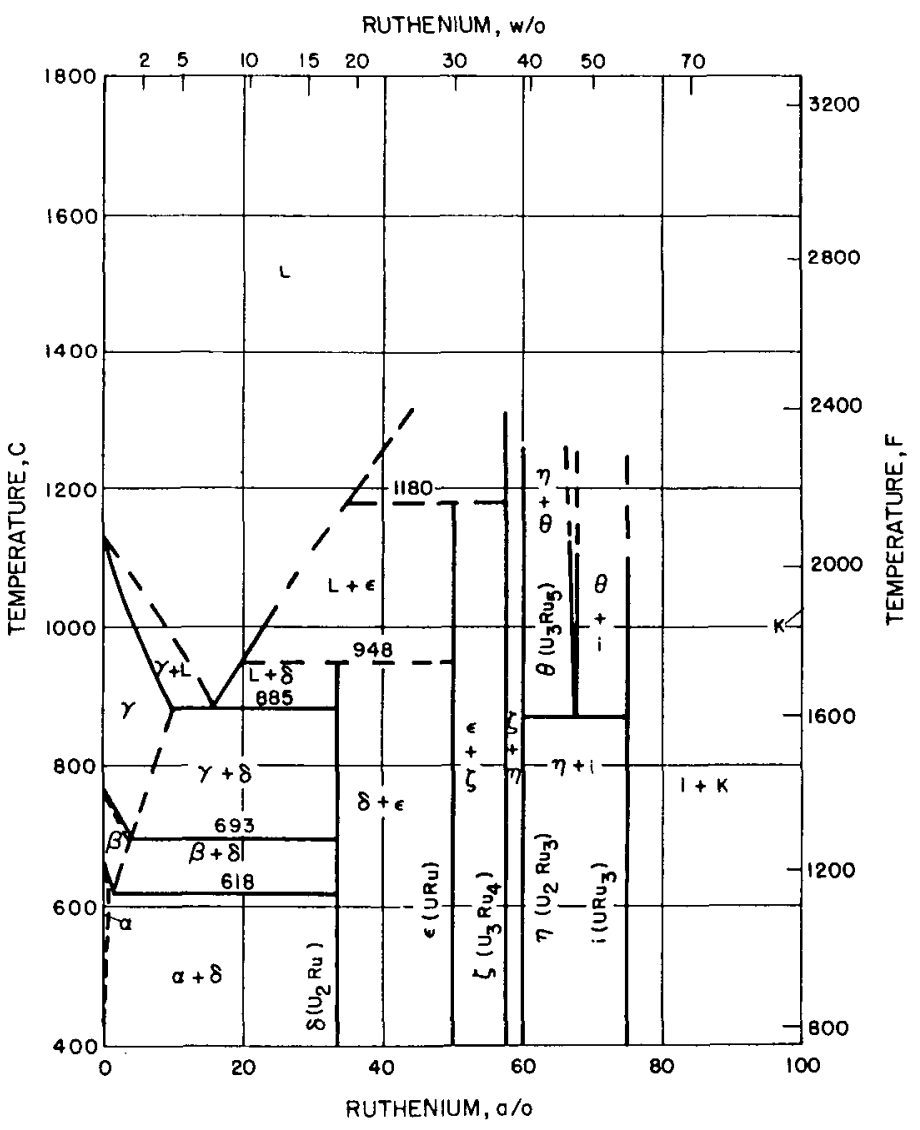


The diagram shown is based on the work of Park $(1)$ revised to include the data of Dwight $(2)$ in the regions of higher ruthenium content. The features of the high-uranium end of the diagram have also been reported by Murray and Lloyd(3) and by Yorke(4), giving excellent agreement with the work of Park.

Park(1) has investigated only the region up to $\mathrm{URu}_{3}$ and reports two compounds of lower ruthenium content, $\mathrm{U}_{2} \mathrm{Ru}$ and $\mathrm{URu}$. Dwight $(2)$ reports three additional compound in this range, between $U R u$ and $U R u_{3}$; these are $U_{3} R u_{4}, U_{2} R u_{3}$, and $U_{3} R u_{5}$, the latter decomposing eutectoidally at $870 \mathrm{C}$ to $\mathrm{U}_{2} \mathrm{Ru}_{3}$ and $\mathrm{URu}_{3}$.

The addition of ruthenium to uranium lowers the beta-to-gamma and alpha-to-beta transformation temperatures. Park(1) reports values of 693 and $618 \mathrm{C}$, respectively, for the se temperatures and $885 \mathrm{C}$ for the eutectic temperature, while Dwight $(2)$ reports values of 708,640 , and $898 \mathrm{C}$, respectively.

\section{Crystallography}

The crystal structure of $\mathrm{URu}_{3}$ has been reported by Heal and Williams (5).

\begin{tabular}{|c|c|c|c|c|c|c|c|}
\hline \multirow[b]{3}{*}{ Phase } & \multicolumn{3}{|c|}{ Unit Cell } & \multirow{2}{*}{\multicolumn{2}{|c|}{$\begin{array}{l}\text { Density, } \\
\text { g/ } \mathrm{cm}^{2}\end{array}$}} & \multirow{3}{*}{$\begin{array}{l}\text { Space } \\
\text { Group }\end{array}$} & \multirow[b]{3}{*}{ Remarks } \\
\hline & \multirow[b]{2}{*}{ Type } & \multirow{2}{*}{$\begin{array}{c}\text { Dimensions, } \\
\mathrm{A}\end{array}$} & \multirow{2}{*}{$\begin{array}{c}\begin{array}{c}\text { Number } \\
\text { of }\end{array} \\
\text { Molecules } \\
\end{array}$} & & & & \\
\hline & & & & X-Ray & Other & & \\
\hline $\mathrm{URu}_{3}$ & $\begin{array}{r}\text { Simple } \\
\text { cubic }\end{array}$ & $3.988 \pm 0.002$ & 1 & 14.24 & -- & $\mathrm{Pm} 3 \mathrm{~m}$ & $\begin{array}{l}\mathrm{L} 12-\mathrm{Cu}_{3} \mathrm{Au} \\
\text { structure }\end{array}$ \\
\hline
\end{tabular}

\section{$\underline{\text { References }}$}

(1) Park, J. J., private communication (October, 1956).

(2) Dwight, A. E., "Nuclear Fuels Newsletter", WASH-702 (May, 1957); WASH-704

(December, 1957). Classified.

(3) Murray, J. R., and Lloyd, S. J., "Some Observations on Uranium-Rich UraniumRuthenium Alloys", AERE M/M 107.

(4) Yorke, J. M., "Alloys of Uranium With Ruthenium and Rhodium", AERE X/PR 2409 (1956).

(5) Heal, T. J., and Williams, G. I., "Compounds of Uranium With the Transitions Metals", Acta Cryst. , 8,494 (1955).

\section{URANIUM-SAM ARIUM}

Uranium and samarium show little miscibility in the liquid state. The solubility of samarium in liquid uranium is reported to be $0.2 \mathrm{w} / 0$ at $1150 \mathrm{C}$ and $0.25 \mathrm{w} / \mathrm{o}$ at $1250 \mathrm{C}$, while uranium solubility in samarium is given as $0.5 \mathrm{w} / 0$ at $1000 \mathrm{C}$ and $1.3 \mathrm{w} / 0$ at $1250 \mathrm{C}$.

\section{Crystallography}

Data concerning the possibility of compounds in this system are not available.

\section{$\underline{\text { Reference }}$}

(1) Wilhelm, H. A., "Nuclear Fuels Newsletter", WASH-704 (December, 1957). Classified. 


\section{URANIUM-SELENIUM}

Data on the uranium-selenium system are incomplete. Ferro reports the presence of three compounds, USe, $\mathrm{U}_{2} \mathrm{Se}_{3}$, USe ${ }_{2}$, in addition to a selenium-rich phase. The USe 2 may exist in two polymorphic forms. In an earlier review by Katz and Rabinowitch, the compounds $\mathrm{U}_{2} \mathrm{Se}_{3}$ and $\mathrm{USe}_{2}$ had been reported. (2)

Crystallography

The crystal structure of USe has been determined by Ferro as given below. A ternary compound, UOSe, occurring in contaminated alloys, has been identified as having tetragonal symmetry and being of the PbFCl-type with $\mathrm{a}=3.901 \mathrm{~A}, \mathrm{c} / \mathrm{a}=1.789$.

\begin{tabular}{|c|c|c|c|c|c|c|c|}
\hline \multirow[b]{3}{*}{ Phase } & \multicolumn{3}{|c|}{ Unit Cell } & \multirow{2}{*}{\multicolumn{2}{|c|}{$\begin{array}{c}\text { Density, } \\
\mathrm{g} / \mathrm{cm}^{3}\end{array}$}} & \multirow[b]{3}{*}{ Space Group } & \multirow[b]{3}{*}{ Remarks } \\
\hline & & Dimensions, & $\begin{array}{c}\text { Number } \\
\text { of }\end{array}$ & & & & \\
\hline & Type & A & Molecules & $\mathrm{X}-\mathrm{Ray}$ & Other & & \\
\hline USe & Cubic & $a=5.750$ & 4 & 11.07 & & & $\begin{array}{l}\mathrm{NaCl-type} \\
\text { structure }\end{array}$ \\
\hline
\end{tabular}

\section{References}

(1) Ferro, R., "Certain Uranium-Selenium and Uranium-Tellurium Compounds", Z. anorg. u. allgem. Chem., 275, 320 (1954).

(2) Katz, J. J., and Rabinowitch, E., The Chemistry of Uranium, Part 1, McGraw-Hill Book Co., Inc., New York (1951), p 337. 


\section{URANIUM-SILICON}

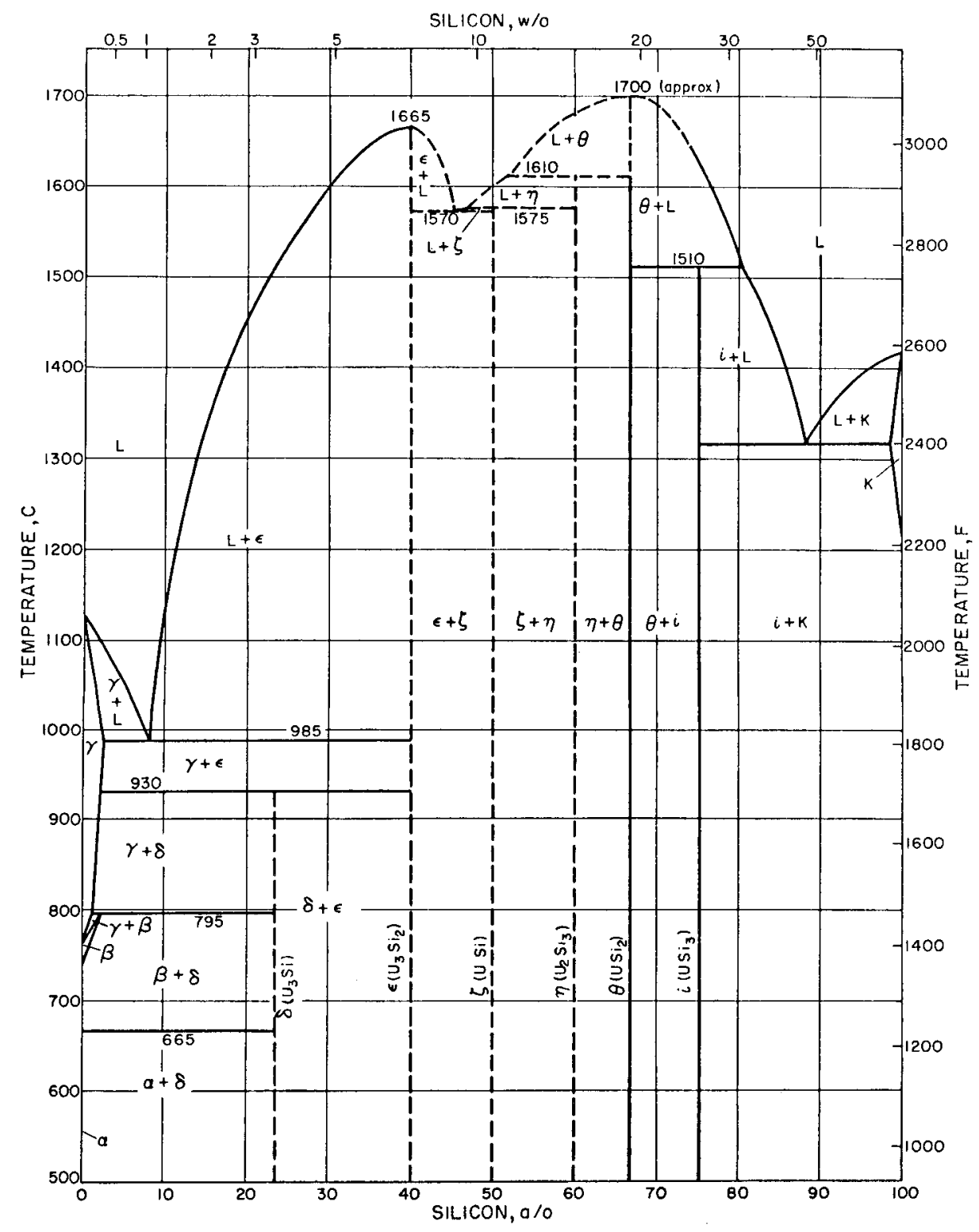

\section{The Constitutional Diagram}

The constitutional diagram for the uranium-silicon system has been determined by Kaufmann (1) as shown in the accompanying figure. The formula $\mathrm{U}_{3} \mathrm{Si}_{2}$ is based upon work of Zachariasen (2), who also reports two forms of USi 2 , one (beta USi ${ }_{2}$ ) corresponding to the $\mathrm{U}_{2} \mathrm{Si}_{3}$ of Kaufmann.

There is no disagreement about the compounds delta $\left(\mathrm{U}_{3} \mathrm{Si}\right)^{(1,2)}$, zeta (USi) $(1,2)$, and iota $\left(\mathrm{USi}_{3}\right)(1,2,3,4)$. However, Kaufmann $(1)$ reports that delta (U⿻ $\mathrm{U}_{3} \mathrm{Si}$ ) actually has a very narrow composition range near 23 a/o silicon, rather than a stoichiometric ratio of $\mathrm{U}_{3} \mathrm{Si}$.

\section{Crystallography}

The data tabulated are from Zachariasen (2), except for iota (USi3), which is from Kaufmann(1). The discrepancies between these data and the constitutional diagram are explained above. 
The structure of iota ( $\mathrm{USi}_{3}$ ) has been determined by others $(3,4)$ and is reported to be the Ll2-type, isomorphous with $\mathrm{UGa}_{3}, \mathrm{UIn}_{3}, \mathrm{UGe}_{3}, \mathrm{UPb}_{3}, \mathrm{UAl}_{3}$, and $\mathrm{USn}_{3}(3)$.

Zachariasen ${ }^{(2)}$ reports that delta $\left(\mathrm{U}_{3} \mathrm{Si}\right)$ is the only one of the intermetallic compounds in this system which does not have covalent bonds between silicon atoms and therefore is metallic in nature. This generalization presumably excludes $\mathrm{USi}_{3}$, since Zachariasen did not report on it.

In epsilon $\left(\mathrm{U}_{3} \mathrm{Si}_{2}\right)$, the silicon atoms are bonded together to form pairs normal to the fourfold axis. In zeta (USi), the silicon atoms are bonded together to form endless zigzag chains along the c-axis. In theta ("beta" USi 2 ), the silicon atoms form "graphite layers" normal to the sixfold axis; and in eta ("alpha" USi 2 ), a three-dimensional network of silicon atoms occurs, with uranium atoms in the interstices.

\begin{tabular}{|c|c|c|c|c|c|c|c|}
\hline \multirow[b]{3}{*}{ Phase } & \multicolumn{3}{|c|}{ Unit Cell } & & & \multirow{3}{*}{$\begin{array}{l}\text { Space } \\
\text { Group }\end{array}$} & \multirow[b]{3}{*}{ Remarks } \\
\hline & \multirow[b]{2}{*}{ Type } & \multirow{2}{*}{$\begin{array}{c}\text { Dimensions, } \\
\mathrm{A} \\
\end{array}$} & \multirow{2}{*}{$\begin{array}{c}\begin{array}{c}\text { Number } \\
\text { of }\end{array} \\
\text { Molecules }\end{array}$} & \multicolumn{2}{|c|}{$\begin{array}{l}\text { Density, } \\
\mathrm{g} / \mathrm{cm}^{3}\end{array}$} & & \\
\hline & & & & X-Ray & Other & & \\
\hline $\begin{array}{l}\text { Delta } \\
\qquad\left(\mathrm{U}_{3} \mathrm{Si}\right)\end{array}$ & $\begin{array}{l}\text { Bc tetrag- } \\
\text { onal }\end{array}$ & $\begin{aligned} a= & 6.029 \pm \\
& 0.002 \\
c= & 8.697 \pm \\
& 0.003\end{aligned}$ & 4 & 15.58 & & $14 / \mathrm{mcm}$ & \\
\hline $\begin{array}{l}\text { Epsilon } \\
\qquad\left(\mathrm{U}_{3} \mathrm{Si}_{2}\right)\end{array}$ & $\begin{array}{l}\text { Tetrag- } \\
\text { onal }\end{array}$ & $\begin{aligned} \mathrm{a}= & 7.3298 \pm \\
& 0.0004 \\
\mathrm{c}= & 3.9003 \pm \\
& 0.0005\end{aligned}$ & 2 & 12. 20 & & $\mathrm{P} 4 / \mathrm{mbm}$ & \\
\hline $\begin{array}{l}\text { Zeta } \\
\text { (USi) }\end{array}$ & $\begin{array}{l}\text { Ortho- } \\
\text { rhombic }\end{array}$ & $\begin{aligned} \mathrm{a}= & 5.66 \pm \\
& 0.01 \\
\mathrm{~b}= & 7.67 \pm \\
& 0.01 \\
\mathrm{c}= & 3.91 \pm \\
& 0.01\end{aligned}$ & 4 & 10.40 & & $\mathrm{Pbnm}$ & $\begin{array}{l}\text { Isomorphous with } \\
\text { FeB }\end{array}$ \\
\hline $\begin{array}{l}\text { Eta } \\
\text { ("alpha" } \\
\text { USi }{ }_{2} \text { ) }\end{array}$ & $\begin{array}{l}\text { Bc tetrag- } \\
\text { onal }\end{array}$ & $\begin{aligned} a= & 3.98 \pm \\
& 0.03 \\
c= & 13.74 \pm \\
& 0.08\end{aligned}$ & 4 & 8.98 & & I4/amd & $\begin{array}{l}\text { Isomorphous } \\
\text { with ThSi } 2, \\
\text { PuSi } 2, \mathrm{CeSi}_{2} \text {, } \\
\text { and } \mathrm{NpSi}_{2}\end{array}$ \\
\hline $\begin{array}{l}\text { Theta } \\
\text { ("beta"' } \\
\text { USi }_{2} \text { ) }\end{array}$ & $\begin{array}{l}\text { Hexag- } \\
\text { onal }\end{array}$ & $\begin{aligned} \mathrm{a}= & 3.86 \pm \\
& 0.01 \\
\mathrm{c}= & 4.07 \pm \\
& 0.01\end{aligned}$ & 1 & 9.25 & & $\mathrm{P} 6 / \mathrm{mmm}$ & $\begin{array}{l}\text { Isomorphous with } \\
\mathrm{AlB}_{2} \text { and } \mathrm{TiB}_{2}\end{array}$ \\
\hline $\begin{array}{l}\text { Iota } \\
\qquad\left(\mathrm{USi}_{3}\right)\end{array}$ & Cubic & $a=4.03$ & 1 & 8.15 & & $\mathrm{Pm} 3 \mathrm{~m}$ & $\begin{array}{l}\text { L12-type, } \\
\text { AuCu }{ }^{\text {ordered }} \\
\text { structure }\end{array}$ \\
\hline
\end{tabular}

\section{References}

(1) Kaufmann, A. R. , Cullity, B. D. , Bitsianes, G., "Uranium Silicon Alloys", J. Metals, 9, 23-27 (January, 1957).

(2) Zachariasen, W. H. , "The Crystal Structure of Uranium Silicides and of CeSi 2 , NpSi 2 , and PuSi $2 "$ (AECD-2092), Acta Cryst., 2, 94-99 (1949).

(3) Maskrey, J. T., and Frost, B. R. T. , "The System Uranium-Lead" (AERE-M/R 1027), J. Inst. Metals, 82 (4), 171-180 (1953).

(4) Iandelli, Aldo, and Ferro, Ricardo, Ann. chim. (Rome), 42, 598-606 (1952). 


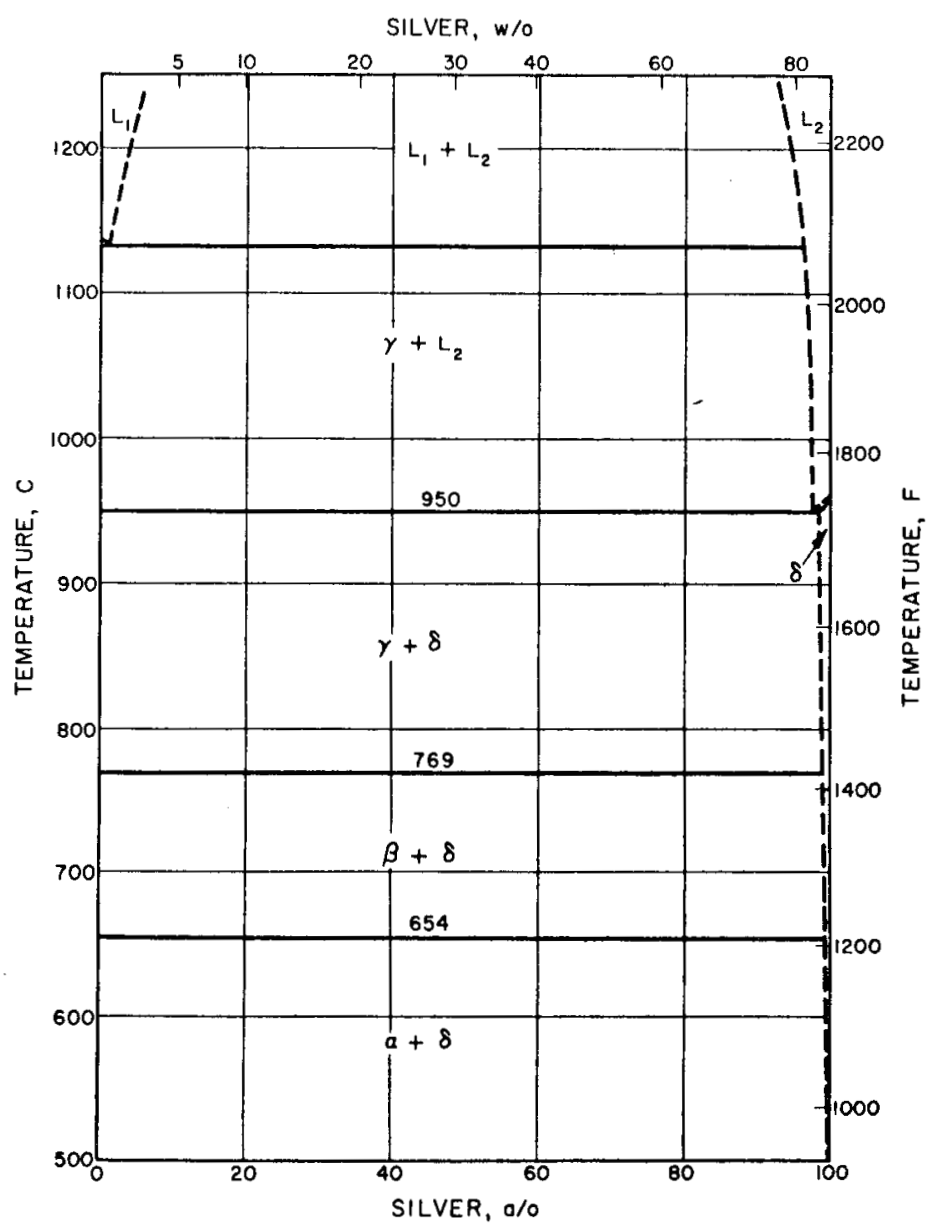

The Constitutional Diagram

Early work on the uranium-silver system $(1,2)$ indicated that uranium and silver are immiscible in the liquid state. More recently, the diagram has been mapped out rather thoroughly by Buzzard and co-workers (3).

The accompanying diagram is from the work of Buzzard(3). The monotectic reaction is reported at $1132 \mathrm{C}$, on the basis of a uranium melting point of $1133 \mathrm{C}$. Buzzard reports the monotectic composition to be about $0.23 \mathrm{w} / \mathrm{o}$ silver at $1132 \mathrm{C}$, while Wilhelm reports it to be about $0.05 \mathrm{w} / \mathrm{o}$ silver(4). Work from the United Kingdon reports the monotectic at $0.28 \mathrm{w} / \mathrm{o}$ silver ${ }^{(\dot{2})}$.

The eutectic at the silver-rich end occurs at about $94.5 \mathrm{w} / \mathrm{o}$ silver and $950 \mathrm{C}(3)$, although another report indicates that it occurs at about $15 \mathrm{a} / \mathrm{o}$ uranium (2).

The maximum solubility in silver is between 0.1 and $0.4 \mathrm{w} / \mathrm{o}$ uranium. Because there is no appreciable solubility of silver in uranium, silver has little effect on the uranium transformation temperatures (3).

\section{Crystallography}

There are no intermetallic compounds in the uranium-silver system. 
$\underline{\text { References }}$

(1) Russell, H. W. , unpublished information (December, 1944).

(2) National Physical Laboratory, United Kingdom, unpublished information (May, 1949).

(3) Buzzard, R. W., Fickle, D. P. , and Park, J. J. , "The Silver-Uranium System" (AECD-3600), J. Research Natl. Bur. Standards, 52(3), 149-52 (1954).

(4) Wilhelm, H. A., and Carlson, O. N., "Uranium Alloy Newsletter" (May, 1954).

\section{UR ANIUM -SODIUM}

The solubility of uranium in liquid sodium at $97.8 \mathrm{C}$ is reported to be less than $0.05 \mathrm{w} / 0$ and may be many times smaller(1). Uranium and sodium in contact for long periods of time at $550 \mathrm{C}$ showed no evidence of reaction(2).

\section{Crystallography}

Probably there are no compounds in this system.

\section{References}

(1) Douglas, T. B., "A Cryoscopic Study of the Solubility of Uranium in Liquid Sodium at 97. 8 C", J. Research Nat1. Bur. Standards, 52, 223-26 (1954).

(2) A.E.R.E., United Kingdom, unpublished information (May, 1957).

\section{UR ANIUM-SULFUR}

The existence of four basic sulfides of uranium has been reported, US, $\mathrm{U}_{5} \mathrm{~S}_{3}, \mathrm{U}_{2} \mathrm{~S}_{3}$, and $\operatorname{US}_{2}(1,2,3,4)$. Zachariasen reports these compounds have well-defined formulae.

The melting point of US has been reported as greater than $2000 \mathrm{C}$, while that of $\mathrm{US}_{2}$ has been reported as $1850 \pm 100 \mathrm{C}(3)$.

$U_{2}$ decomposes to $U_{2} S_{3}$ in a vacuum at $1300 \mathrm{C}(5)$. At $1530 \mathrm{C}$, the decomposition product of $\mathrm{US}_{2}$ is reported to be $\mathrm{U}_{5} \mathrm{~S}_{3}(6)$.

Various reports indicate that $\mathrm{US}_{2}$ exists in two forms $(5,7,8)$. The transition temperature from the orthorhombic to tetragonal form is reported to be about $1350 \mathrm{C}$. Below this temperature, the two forms can coexist $(7)$.

Additional discussion is available ${ }^{(8)}$.

\section{Crystallography}

The crystallography of the compounds US, $\mathrm{U}_{5} \mathrm{~S}_{3}, \mathrm{U}_{2} \mathrm{~S}_{3}$, "alpha" US 2 , and "beta" US 2 is tabulated below. The data for $\mathrm{U}_{5} \mathrm{~S}_{3}, \mathrm{U}_{2} \mathrm{~S}_{3}$, and beta $\mathrm{US}_{2}$ are from Picon $(4,7)$ while the data for US and alpha US, are from Zachariasen(1). Picon(7) gives the following for alpha $\mathrm{US}_{2}$ : orthorhombic; $\mathrm{a}=4.12, \mathrm{~b}=7.11, \mathrm{c}=8.46 \mathrm{~A}$; density, $8.07 \pm 0.06 \mathrm{~g} / \mathrm{cm}^{3}$. Data for $\mathrm{U}_{2} \mathrm{~S}_{3}$ are given by Zachariasen (l) as follows: orthorhombic; $a=10.41, \mathrm{~b}=10.65, \mathrm{c}=3.89 \mathrm{~A}$; density, $8.78 \mathrm{~g} / \mathrm{cm}^{3}$.

A subsulfide has been reported by Zumbusch(9). Zachariasen(2) attributes this report to UOS, which has been found to have a tetragonal structure with a $=3.835 \pm 0.001$ and $c=6.681 \pm 0.001 \mathrm{~A}$, with a density of $9.60 \mathrm{~g} / \mathrm{cm}^{3}$. The UOS structure is the PbFC1-type with a $\mathrm{P} 4 / \mathrm{nmm}$ space group. 


\begin{tabular}{|c|c|c|c|c|c|c|c|}
\hline \multirow[b]{3}{*}{ Phase } & \multicolumn{3}{|c|}{ Unit Cell } & & & \multirow{3}{*}{$\begin{array}{l}\text { Space } \\
\text { Group }\end{array}$} & \multirow[b]{3}{*}{ Remarks } \\
\hline & \multirow[b]{2}{*}{ Type } & \multirow{2}{*}{$\begin{array}{c}\text { Dimensions, } \\
\mathrm{A}\end{array}$} & \multirow{2}{*}{$\begin{array}{c}\begin{array}{c}\text { Number } \\
\text { of }\end{array} \\
\text { Molecules } \\
\end{array}$} & \multicolumn{2}{|c|}{$\begin{array}{c}\text { Density, } \\
\text { g/ } \mathrm{cm}^{3}\end{array}$} & & \\
\hline & & & & X-Ray & Other & & \\
\hline US & $\mathrm{Bcc}$ & $\begin{aligned} a= & 5.484 \pm \\
& 0.002\end{aligned}$ & 4 & 10.87 & & & $\begin{array}{c}\mathrm{NaCl-type} \\
\text { structure } \\
\text { soluble } \\
\text { with } \mathrm{ThS} \\
\text { and } \mathrm{CeS}\end{array}$ \\
\hline $\mathrm{U}_{3} \mathrm{~S}_{5}$ & Orthorhombic & $\begin{aligned} \mathrm{a}= & 7.41 \pm 0.02 \\
\mathrm{~b}= & 8.06 \pm 0.02 \\
\mathrm{c}= & 11.70 \pm \\
& 0.03\end{aligned}$ & 4 & 8.31 & $\begin{array}{l}8.30 \pm \\
0.05\end{array}$ & & \\
\hline $\mathrm{U}_{2} \mathrm{~S}_{3}$ & Orthorhombic & $\begin{aligned} a= & 10.34 \pm \\
& 0.02 \\
b= & 10.58 \pm \\
& 0.02 \\
c= & 3.855 \pm \\
& 0.004\end{aligned}$ & 4 & 9.01 & $\begin{array}{c}8.94 \pm \\
0.07\end{array}$ & Pbnm & $\begin{array}{l}\mathrm{Sb}_{2} \mathrm{~S}_{3} \text {-type } \\
\text { structure; } \\
\text { isomor- } \\
\text { phous with } \\
\mathrm{Np}_{2} \mathrm{~S}_{3} \text { and } \\
\mathrm{Th}_{2} \mathrm{~S}_{3}\end{array}$ \\
\hline $\begin{array}{l}\text { "Alpha" } \\
\mathrm{US}_{2}\end{array}$ & Or thorhombic & $\begin{array}{l}a=4.22 \pm 0.02 \\
b=7.08 \pm 0.04 \\
c=8.45 \pm 0.04\end{array}$ & 4 & 7.90 & & Pmnb & $\begin{array}{l}\text { Isomor- } \\
\text { phous } \\
\text { with ThS } 2\end{array}$ \\
\hline $\begin{array}{l}\text { "Beta" } \\
\text { US } 2\end{array}$ & Tetragonal & $\begin{array}{l}a=10.26 \\
c=6.30\end{array}$ & & & $\begin{array}{c}7.60 \pm \\
0.06\end{array}$ & & \\
\hline
\end{tabular}

\section{$\underline{\text { References }}$}

(1) Zachariasen, W. H., "Crystal Structure of Sulfides and Oxy-sulfides of Uranium, Thorium, and Cerium", AECD-2141 (September 11, 1946).

(2) Zachariasen, W. H., "Crystal Chemical Studies of the 5-f Series Elements, X. Sulfides and Oxy-sulfides", Acta Cryst., 2, 291-296 (1949).

(3) Eastman, E. D. , Brewer, L. , and Bromley, L., "Preparation and Properties of the Sulfides of Thorium and Uranium", J. Am. Chem. Soc., 72, 4019-23 (1950).

(4) Picon, M. , and Flauhaut, J., "The Properties of Uranium Sulfides $\mathrm{S}_{5} \mathrm{U}_{3}$ and $\mathrm{S}_{3} \mathrm{U}_{2}$ ", Compt. rend., 240, 784-785 (1955).

(5) Picon, M. , and Flauhaut, J., "Properties of the Sulfides of Uranium US 2 , Alpha and Beta", Compt. rend, , 237, 1160-2(1953).

(6) Picon, M., and Flauhaut, J., "Uranium Sulfides", Compt. rend. , 240, 535-6 (1955).

(7) Picon, M. , and Flauhaut, J., "Dimorphism of the Sulfide of Uranium, US 2 ", Compt. rend., 237, 808-10 (1953).

(8) Katz, J. J., and Rabinowitch, E., The Chemistry of Uranium, Part I, McGraw-Hill Book Co. , Inc. , New York (1951), pp 330-335.

(9) Zumbusch, M., "The Structure of Uranium-Subsulfide and of the Subsulfides of Iridium and Rhodium", Z. anorg. u. allgem. Chem.: 243, 322-9 (1940). 


\section{URANIUM-TANT ALUM}

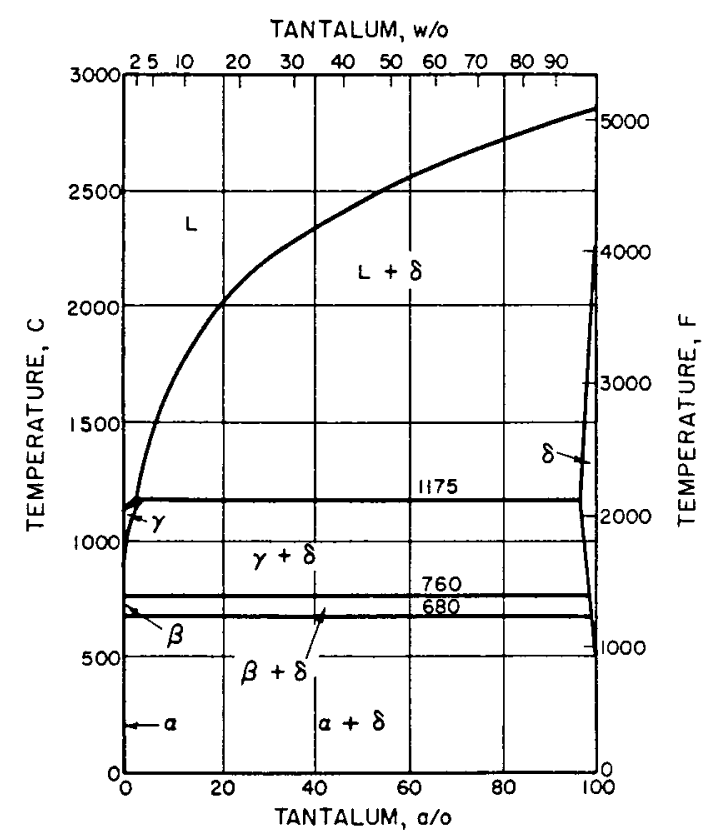

\section{The Constitutional Diagram}

Early work by Ahmann(1) indicated that no intermetallic compounds exist in the uraniumtantalum system and that a peritectic reaction occurs at the uranium end of the system.

Schramm, Gordon, and Kaufmann (2) studied the system more intensively and established the constitutional diagram as shown.

Both tantalum and tungsten form peritectic systems with limited solid solutions. In the case of tantalum, the peritectic temperature is $1175 \mathrm{C}$. The solubility of tantalum in uranium and of uranium in tantalum is probably less than $2 \mathrm{a} / \mathrm{o}^{(2)}$.

A ternary carbide, approximating $\mathrm{UTa}_{10} \mathrm{C}_{4}$, was observed which is more stable than the carbides of either uranium or tantalum alone. This carbide is of low symmetry but the structure is undetermined(2). A second ternary carbide is reported to be face-centered cubic with $a=4.41 \mathrm{~A}$.

Data from the United Kingdom support the general features of the system uraniumtantalum(3).

\section{Crystallography}

There are no intermetallic compounds in the uranium-tantalum system.

\section{References}

(I) Ahmann, D. H. , unpublished information (March, 1946).

(2) Schramm, C. H., Gordon, A. R., and Kaufmann, A. R., "The Alloy Systems UraniumTungsten, Uranium-Tantalum, and Tungsten-Tantalum" (AECD-2686), J. Metals, 2 (1949).

(3) Atomic Energy Research Establishment, United Kingdom, unpublished information (1954). 


\section{URANIUM-TELLURIUM}

The uranium-tellurium system is incompletely known; however, Ferro reports the compounds $\mathrm{UTe}, \mathrm{U}_{3} \mathrm{Te}_{4}, \mathrm{U}_{2} \mathrm{Te}$, and $\mathrm{UTe}_{2}$, in addition to a phase of higher tellurium content. (1) The latter phase may correspond to the UTe 2,2 described by Montignie. (2) Katz and Rabinowitch, in an earlier review of the system, concluded that $\mathrm{UTe}_{\mathrm{T}} \mathrm{U}_{2} \mathrm{Te}_{3}$, and $\mathrm{UTe}_{2} .2$ were among the compounds found in the system. (3)

\section{Crystallography}

The structures below for UTe, $\mathrm{U}_{3} \mathrm{Te}_{4}$, and $\mathrm{UTe}_{2}$ are from Ferro ${ }^{(1)}$.

\begin{tabular}{|c|c|c|c|c|c|c|c|}
\hline \multirow[b]{3}{*}{ Phase } & \multicolumn{3}{|c|}{ Unit Cell } & \multirow{2}{*}{\multicolumn{2}{|c|}{$\begin{array}{l}\text { Density } \\
\mathrm{g} / \mathrm{cm}^{3}\end{array}$}} & \multirow{3}{*}{$\begin{array}{l}\text { Space } \\
\text { Group }\end{array}$} & \multirow[b]{3}{*}{ Remarks } \\
\hline & \multirow[b]{2}{*}{ Type } & \multirow{2}{*}{$\begin{array}{c}\text { Dimensions, } \\
\mathrm{A}\end{array}$} & \multirow{2}{*}{$\begin{array}{c}\begin{array}{c}\text { Number } \\
\text { of }\end{array} \\
\text { Molecules } \\
\end{array}$} & & & & \\
\hline & & & & X-Ray & Other & & \\
\hline $\mathrm{UTe}$ & Cubic & $a=6.163$ & 4 & 10.37 & & & $\begin{array}{l}\text { NaCl-type } \\
\text { structure }\end{array}$ \\
\hline $\mathrm{U}_{3} \mathrm{Te}_{4}$ & Cubic & $a=9.397$ & 4 & & & $I 43 \mathrm{~d}$ & $\begin{array}{c}\mathrm{Th}_{3} \mathrm{P}_{4} \text {-type } \\
\text { structure }\end{array}$ \\
\hline $\mathrm{UTe}_{2}$ & Tetragonal & $\begin{array}{l}a=4.006 \\
c=7.471\end{array}$ & & & & & \\
\hline
\end{tabular}

\section{References}

(1) Ferro, R., "Certain Uranium-Selenium and Uranium-Tellurium Compounds", Z. anorg. u. allgem. Chem., 275, 320 (1954).

(2) Montignie, E., Bull, soc. chim. France, 748-49 (1947).

(3) Katz, J. J., and Rabinowitch, E. , The Chemistry of Uranium, Part I, McGraw-Hill Book Co. , Inc., New York (1951), 337.

\section{URANIUM-TERBIUM}

Uranium and terbium exhibit an immiscibility gap in the liquid state. Solubility of terbium in liquid uranium is reported to increase from $0.2 \mathrm{w} / 0$ at $1150 \mathrm{C}$ to $0.4 \mathrm{w} / 0$ at $1250 \mathrm{C}(1)$.

\section{Crystallography}

Nothing is known concerning the possibility of compounds in this system.

\section{Reference}

(1) Wilhelm, H. A., "Nuclear Fuels Newsletter", WASH-704 (December, 1957). Classified.

\section{URANIUM-THALLIUM}

An intermetallic compound, $\mathrm{UTl}_{3}$, has been reported. (1) Solubility of uranium in liquid thallium is reported to increase from $0.12 \mathrm{w} / 0$ at $800 \mathrm{C}$ to $0.17 \mathrm{w} / 0$ at $900 \mathrm{C}$. 
Crystallography

The tabulated data for $\mathrm{UTl}_{3}$ are from the work of Iandelli and Ferro(1).

\begin{tabular}{|c|c|c|c|c|c|c|c|}
\hline \multirow[b]{3}{*}{ Phase } & \multirow[b]{3}{*}{ Type } & \multicolumn{2}{|l|}{ Unit Cell } & \multirow{2}{*}{\multicolumn{2}{|c|}{$\begin{array}{c}\text { Density, } \\
\mathrm{g} / \mathrm{cm}^{3}\end{array}$}} & \multirow{3}{*}{$\begin{array}{l}\text { Space } \\
\text { Group }\end{array}$} & \multirow[b]{3}{*}{ Remarks } \\
\hline & & \multirow{2}{*}{$\begin{array}{c}\text { Dimensions, } \\
\mathrm{A} \\
\end{array}$} & \multirow{2}{*}{ 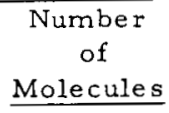 } & & & & \\
\hline & & & & X-Ray & Other & & \\
\hline $\mathrm{UTl}_{3}$ & Simple cubic & $a=4.675$ & 1 & & & Pm 3m & $\begin{array}{l}\text { Isomorphous with } \\
\text { UGa }_{3}, \mathrm{UIn}_{3} \text {, } \\
\mathrm{USi}_{3}, \mathrm{UGe}_{3} \text {, and } \\
\mathrm{UPb}_{3}\end{array}$ \\
\hline
\end{tabular}

References

(1) Iandelli, Aldo, and Ferro, Ricardo, Ann. chim. (Rome), 42, 598-608 (1952).

(2) Hayes, E. E., and Gordon, P., J. Met. and Cer., TID-65, 130-4l (July, 1948). Clas sified.

\section{UR ANIUM-T HORIUM}

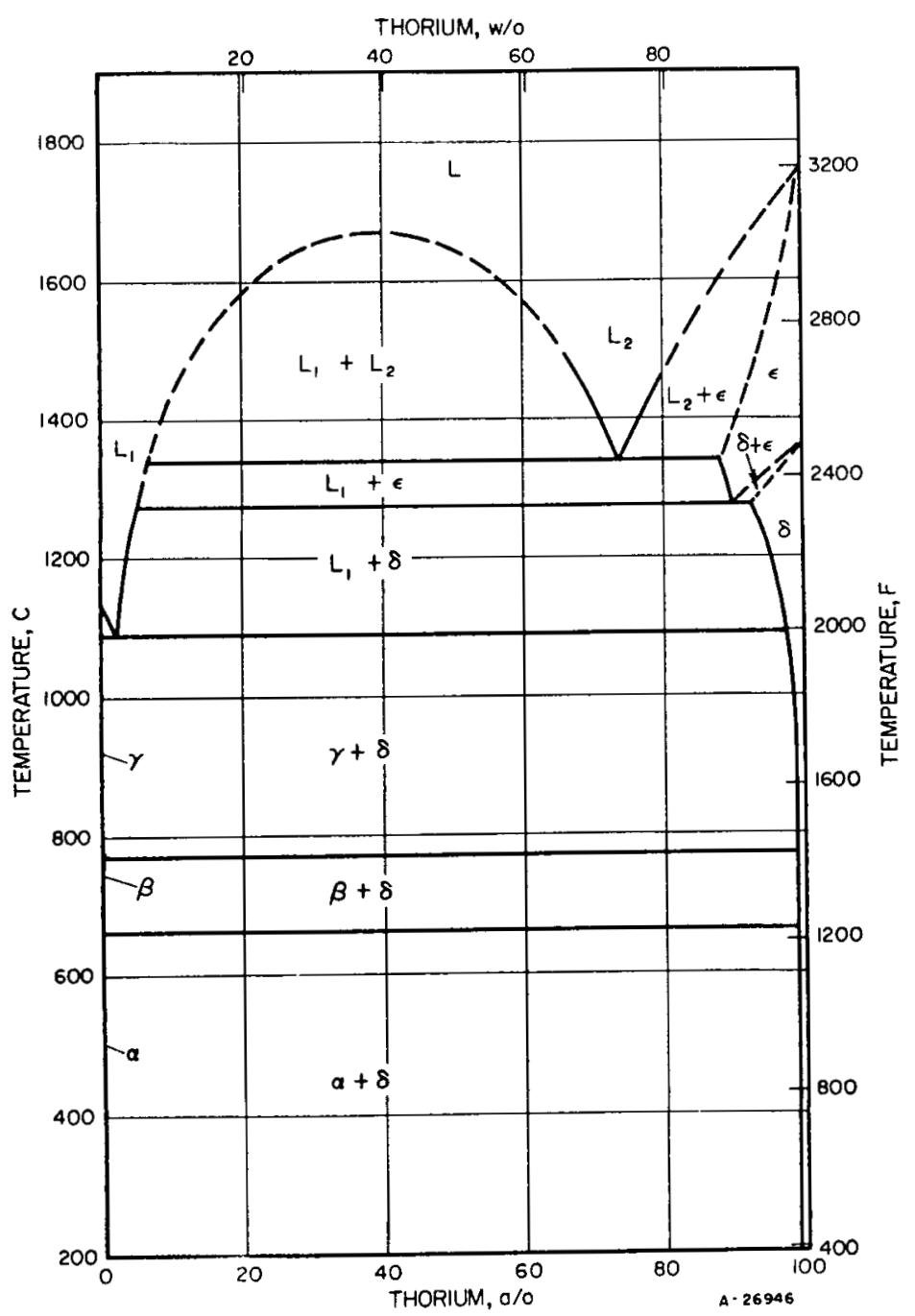




\section{The Constitutional Diagram}

The diagram shown is based upon the work of Carlson $(1,2)$, modified to include the results of Bentle(3) at the high-thorium end of the system. The general characteristics are confirmed by Murray(4), except that the immiscibility gap is reported to extend from 6 to 50 a/ o thorium.

Solubility of thorium in uranium is very limited, being 0.30 a/o thorium at $900 \mathrm{C}$ and less than $0.5 \mathrm{a} / 0$ thorium at $700 \mathrm{C}^{(4)}$.

The details of the high-thorium portion of the system were determined by electricalresistivity measurements and room-temperature $\mathrm{X}$-ray lattice-parameter measurements. Solubility of uranium in thorium is given as being $0.7,1.1,1.1,1.8$, and $2.7 \mathrm{w} / 0$ at 25 , $600,800,1000$, and $1100 \mathrm{C}(3)$. Bauer ${ }^{(5)}$ gives values of $0.7,0.7$, and $1.75 \mathrm{w} / \mathrm{o}$ uranium at 800,900 , and $1000 \mathrm{C}$, while Murray reports values of 1.0 and $2.45 \mathrm{a} / 0$ at 800 and $1300 \mathrm{C}$, respectively. Wilson ${ }^{(6)}$ reports slightly higher values, giving $2.5,4.5$, and $7.5 \mathrm{w} / 0$ uranium at 950,1150 , and $1250 \mathrm{C}$ on the basis of high-temperature X-ray measurements.

\section{Crystallography}

There are no intermetallic compounds in the system uranium-thorium.

\section{References}

(1) Carlson, O. N., "Some Studies of the Uranium-Thorium-Zirconium Ternary Alloy System", AECD-3206 (June 5, 1950).

(2) Carlson, O. N., and Daane, A. H., "The Tuballoy-Thorium Binary System", CT-2717 (April, 1945).

(3) Bentle, G. G., "A Physical Metallurgical Study of Thorium-Rich Thorium-Uranium Alloys", NAA-SR-2069 (January 15, 1958).

(4) Murray, J. R. , United Kingdom, unpublished information (1957).

(5) Bauer, A. A., Rough, F. A., and Dickerson, R. F., "An Investigation of Uranium Solid Solubility in Thorium", BMI-1188 (May 29, 1957).

(6) Wilson, W. B., Austin, A. E., and Schwartz, C. M., "The Solid Solubility of Uranium in Thorium and the Allotropic Transformation of Thorium-Uranium Alloys", BMI- 1111 (July 12, 1956).

\section{URANIUM -THULIUM}

Uranium and thulium exhibit an immiscibility gap in the liquid state. Solubility of thulium in liquid uranium is reported to increase from $0.025 \mathrm{w} / \mathrm{o}$ at $1150 \mathrm{C}$ to $0.075 \mathrm{w} / \mathrm{o}$ at $1250 \mathrm{C}(1)$

\section{Crystallography}

Nothing is known concerning the possibility of compounds in this system.

\section{$\underline{\text { Reference }}$}

(1) Wilhelm, H. A., "Nuclear Fuels Newsletter", WASH-704 (December, 1957). Classified. 


\section{URANIUM-TIN}

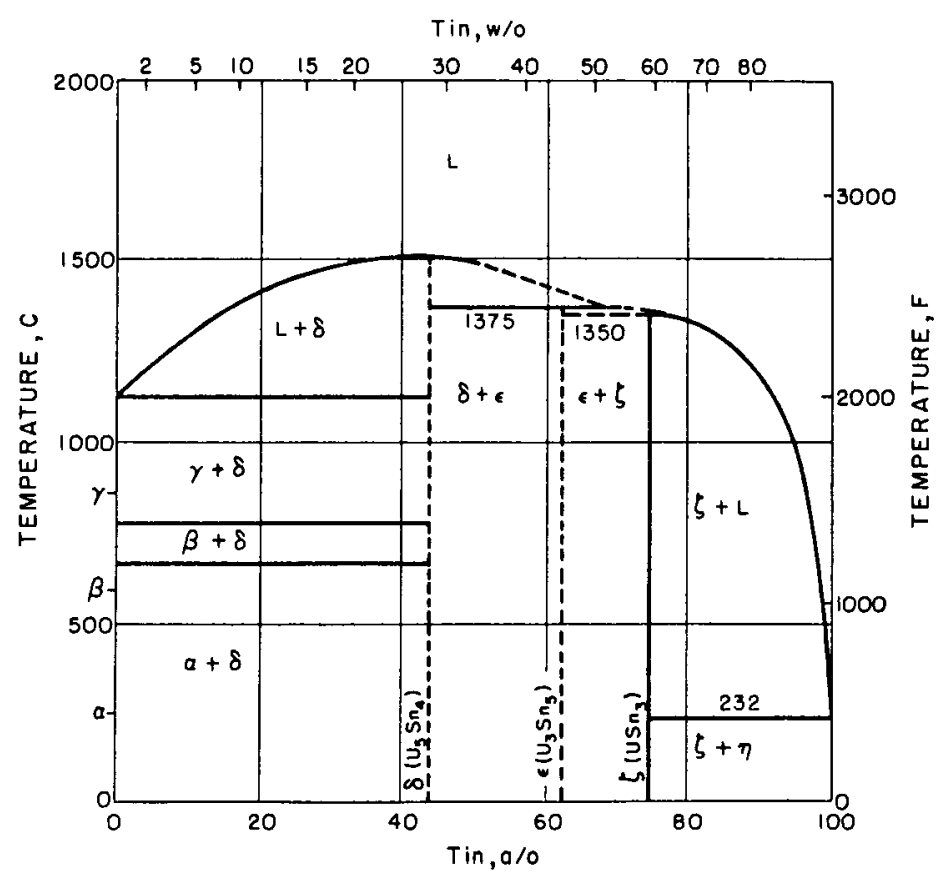

The Constitutional Diagram

The diagram shown was determined by Treick and associates (1). Except for USn3, the compound compositions are not accurately known because of the pyrophoricity of these compounds and the consequent difficulty in handling(2). The diagram is based on the result of metallographic examination, thermal analysis, and X-ray diffraction.

The $\mathrm{USn}_{3}$ has also been reported by Maskrey(3).

\section{Crystallography}

Data are available only for $\mathrm{USn}_{3}$. The data in the table are from Rundle(2). Maskrey reports similar information, giving a value $a=4.626 \mathrm{~A}$. It is an ordered phase and is reported to be isomorphous with $\mathrm{UAl}_{3}, \mathrm{UGa}_{3}, \mathrm{UIn}_{3}, \mathrm{USi}_{3}$, and $\mathrm{UPb}_{3}$. (3)

\begin{tabular}{|c|c|c|c|c|c|c|c|}
\hline \multirow[b]{3}{*}{ Phase } & \multicolumn{3}{|c|}{ Unit Cell } & \multirow{2}{*}{\multicolumn{2}{|c|}{$\begin{array}{r}\text { Density, } \\
\mathrm{g} / \mathrm{cm}^{3} \\
\end{array}$}} & \multirow{3}{*}{$\begin{array}{l}\text { Space } \\
\text { Group }\end{array}$} & \multirow[b]{3}{*}{ Remarks } \\
\hline & & \multirow{2}{*}{$\begin{array}{c}\text { Dimensions, } \\
\mathrm{A}\end{array}$} & $\begin{array}{c}\text { Number } \\
\text { of }\end{array}$ & & & & \\
\hline & Type & & Molecules & X-Ray & Other & & \\
\hline $\mathrm{USn}_{3}$ & Simple cubic & $a=4.63$ & 1 & 9.95 & & $\operatorname{Pr} 3 \mathrm{~m}$ & $\begin{array}{l}\text { Ll2-type, } \mathrm{AuCu}_{3} \\
\text { ordered struc- } \\
\text { ture; isomor- } \\
\text { phous with } \mathrm{UAl}_{3}\end{array}$ \\
\hline
\end{tabular}

\section{References}

(1) Treick, D. A. , Carter, J. H. , Snow, A. I. , Baldwin, R. R., and Wilson, A. S. , "The Uranium-Tin System", M-3107 (1945).

(2) Rundle, R. E. , and Wilson, A. S. , "The Structure of Some Metal Compounds of Uranium" (AECD-2388), Acta.Cryst., 2, 148-150 (1949).

(3) Maskrey, J. T., and Frost, B. R. T., "The System Uranium-Lead", (AERE M/R 1027), J. Inst. Metals, 82 (4), 171-180 (1953). 


\section{URANIUM-TIT ANIUM}

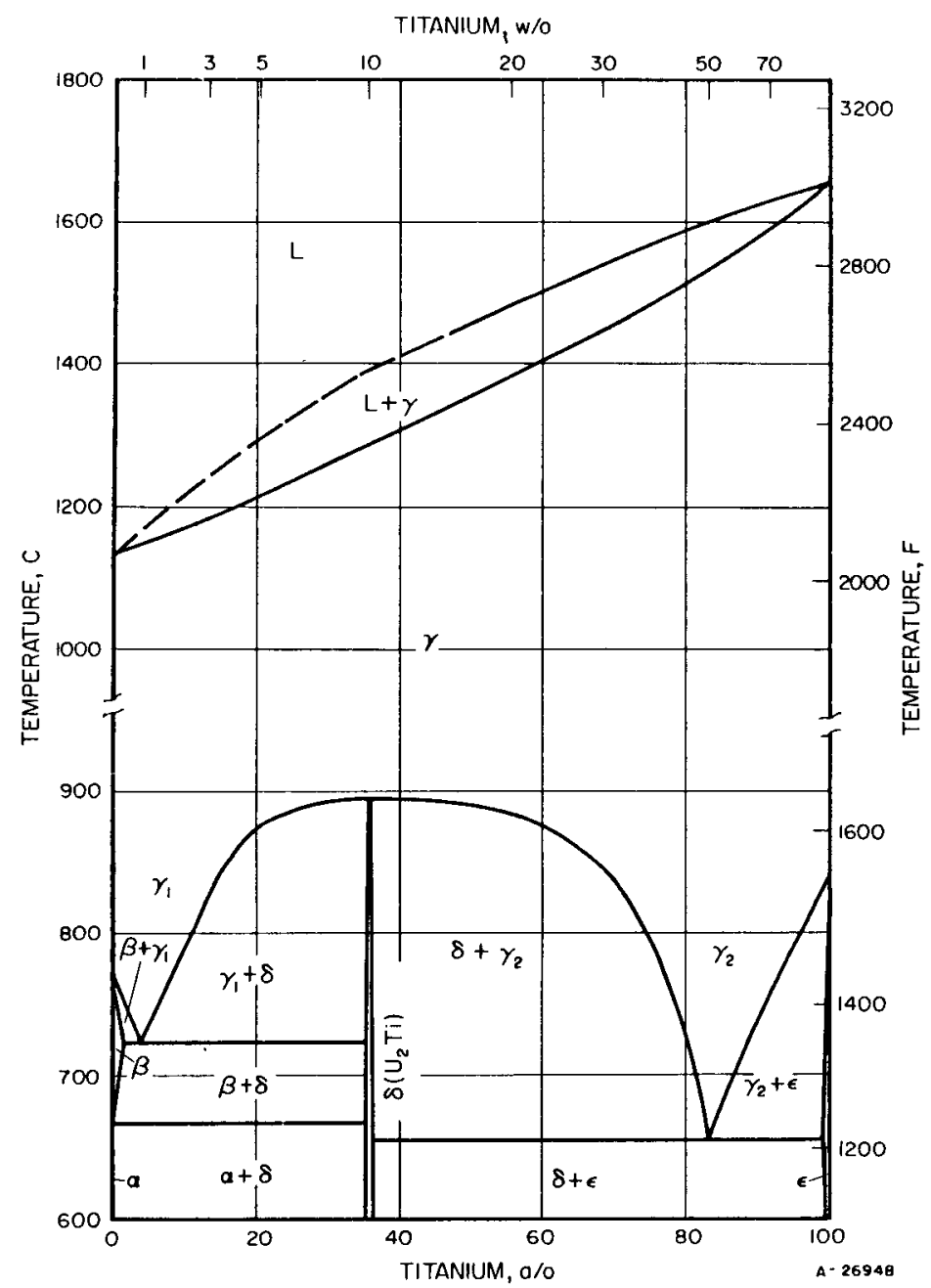

\section{The Constitutional Diagram}

The diagram shown is from Knapton ${ }^{(1)}$ and is in essential agreement with the work of Udy and Boulger(2). The principal differences are in reported solubilities of titanium in the alpha- and beta-uranium phases and in the solubility range of the delta $\left(\mathrm{U}_{2} \mathrm{Ti}\right)$ phase. Udy and Boulger report maximum values for titanium solubility in the alpha and beta phases as 4 and $3 \mathrm{a} / 0$, respectively(2). Knapton reports that impurities are gettered by initial titanium additions resulting in apparently large solubility values; values of less than 1 a/o and $1-1 / 2$ a/o are given for alpha and beta solubilities(1). Knapton, in performing a detailed study of the delta $\left(\mathrm{U}_{2} \mathrm{Ti}\right)$ phase region reports $(1)$ a very limited range of solubility for $\mathrm{U}_{2} \mathrm{~T} i$ on the basis of both metallographic and $\mathrm{X}$-ray studies, which showed that little change in parameter values was observed with change in composition in the vicinity of the delta phase. Udy and Boulger had reported (2) a solubility range for the delta $\left(\mathrm{U}_{2} \mathrm{Ti}\right.$ ) phase of from about 28 to $42 \mathrm{a} / \mathrm{o}$ titanium.

Early reports of a peritectic reaction at the uranium end of the system are undoubtedly in error. (3)

Minor differences in remaining features of the diagram have been reported. Knapton( $(1)$ places the gamma eutectoid at $4 \mathrm{a} / 0$ titanium and $723 \mathrm{C}$. Udy (2) reports $6.0 \mathrm{a} / \mathrm{o}$ and $718 \mathrm{C}$ for the same point. The eutectoid at the titanium end of the system has been reported as 83 a/o titanium by Knapton(1), 72 a/o titanium by $U d y(2)$, and 77 a/o titanium by Seybolt (4). Impurities, notably oxygen and nitrogen, are undoubtedly responsible for at least part of the variations in reported values. $655 \mathrm{C}^{(1)}$.

The solubility of uranium in epsilon (alpha titanium) is reported as about 0.8 a/o at 


\section{Crystallography}

The data tabulated below are from Knapton ${ }^{(5)}$. Similar data have been reported by Tucker ${ }^{(6)}$, giving $\mathrm{a}=4.826 \mathrm{~A}$ and $\mathrm{c}=2.852 \mathrm{~A}$.

\begin{tabular}{|c|c|c|c|c|c|c|c|}
\hline \multirow[b]{3}{*}{ Phase } & \multicolumn{3}{|c|}{ Unit Cell } & \multirow{2}{*}{\multicolumn{2}{|c|}{$\begin{array}{r}\text { Density, } \\
\mathrm{g} / \mathrm{cm}^{3}\end{array}$}} & \multirow{3}{*}{$\begin{array}{l}\text { Space } \\
\text { Group }\end{array}$} & \multirow[b]{3}{*}{ Remarks } \\
\hline & & Dimensions, & $\begin{array}{c}\text { Number } \\
\text { of }\end{array}$ & & & & \\
\hline & Type & A & Molecules & X-Ray & Other & & \\
\hline $\begin{array}{l}\text { Delta } \\
\qquad\left(\mathrm{U}_{2} \mathrm{~T} i\right)\end{array}$ & Hexagonal & $\begin{array}{l}a=4.828 \\
c=2.847\end{array}$ & 1 & & & $\mathrm{P} 6 / \mathrm{mmm}$ & $\begin{array}{l}\text { C32-type; } \\
\text { isostruc- } \\
\text { tural } \\
\text { with } \mathrm{AlB}_{2}\end{array}$ \\
\hline
\end{tabular}

\section{References}

(1) Knapton, A. G. , "The System Uranium-Titanium", J. Inst. Meta1s, 83, 497 (1954-55).

(2) Udy, M. C., and Boulger, F. W., "Uranium-Titanium Alloy System", Trans. AIME, $200,207-210$ (1954).

(3) Buzzard, R. W., Liss, R. B., and Fickle, D. P., "Titanium-Uranium System in the Region Zero to Thirty Atomic Per Cent Titanium" (AECD-3418), J, Research Natl. Bur. Standards, 50, 209-14 (1953).

(4) Seybolt, A. U., White, D. W., Boulger, F. W., and Udy, M. C., "Tentative UraniumTitanium Phase Diagram", TID-71, $118-119$ (1951).

(5) Knapton, A. G. , Acta Cryst., 7, 457 (1954).

(6) Tucker, C. W. , Jr., Knolls Atomic Power Laboratory, unpublished information (1950).

\section{URANIUM-TUNGSTEN}

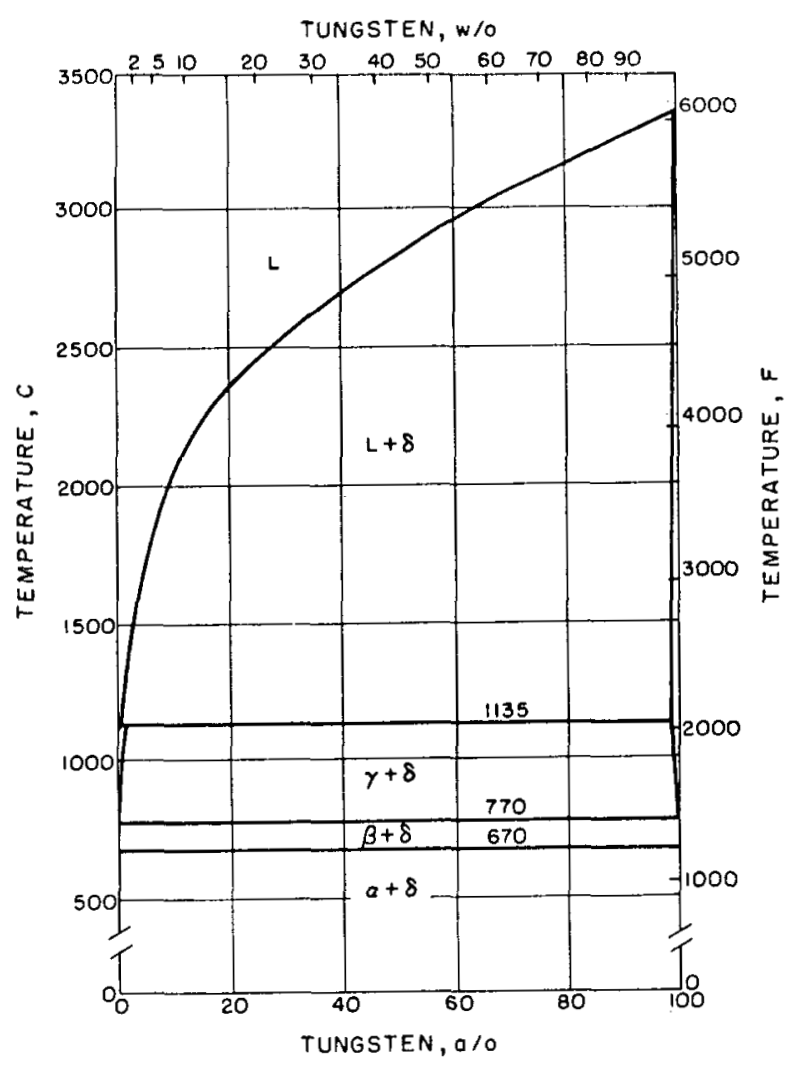




\section{The Constitutional Diagram}

The constitutional diagram of the uranium-tungsten system is similar to that of the uranium-tantalum system. A peritectic reaction occurs at the uranium end of the system, although the temperature of the peritectic is only slightly above the melting point of uranium $(1)$.

Schramm, Gordon, and Kaufmann report that the solubility of uranium in tungsten and of tungsten in uranium is less than 1 a/o. (1) Recent reports from the United Kingdom are in agreement and give solubilities of 0.2 to $0.5 \mathrm{a} / 0$ tungsten $(2)$ and 0.4 to $0.7 \mathrm{a} / \mathrm{O}$ tungsten in uranium at $1000 \mathrm{C}$. A solubility of 0.1 a/o uranium in tungsten at $1000 \mathrm{C}$ is also reported $(3)$.

\section{Crystallography}

There are not intermetallic compounds in the system uranium-tungsten.

\section{References}

(1) Schramm, C. H., Gordon, P., and Kaufmann, A. R., "The Alloy Systems UraniumTungsten, Uranium-Tantalum, and Tungsten-Tantalum" (AECD-2686), J. Metals, $188,195-204(1950)$.

(2) National Physical Laboratory, United Kingdom, unpublished information (October, 1948).

(3) Summers - Smith, D. , "The System Uranium-Tungsten", J. Inst. Met. , 83, 383 (1954-1955).

\section{URANIUM-VANADIUM}

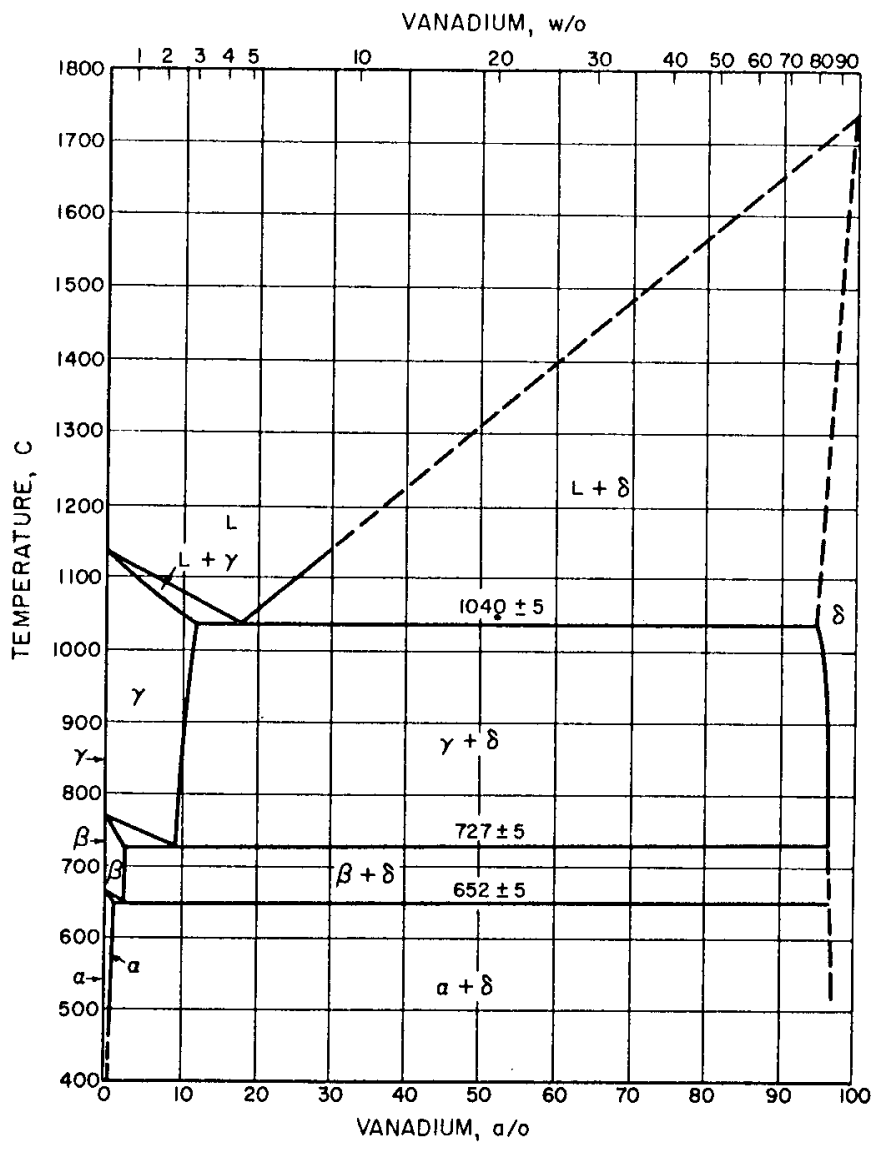




\section{The Constitutional Diagram}

The diagram as shown was determined by Saller and Rough(1). The solubility in the gamma was found to be a maximum of about 12 a/o vanadium at the eutectic and 9 a/o vanadium at the $727 \mathrm{C}$ eutectoid. The solubility in the beta is about 2 a/o vanadium and in the alpha less than 1.5 a/o vanadium. The solubility of uranium in vanadium is limited at all temperatures, with a maximum value of about 4 a/o uranium at $1040 \mathrm{C}$.

The diagram was determined principally by thermal analysis and metallography, and the absence of intermetallic compounds was confirmed by X-ray diffraction.

Seybolt ${ }^{(2)}$ has reported that an allotropic modification of vanadium occurs at $1550 \mathrm{C}$. This conclusion is based on thermal and thermoelectric measurements. McCaldin and Duwe ${ }^{(3)}$ did not find evidence of the modification by thermal analysis. Saller and Rough examined vanadium by thermal analysis, but did not go above $1200 \mathrm{C}$. Since it has not been confirmed, the proposed modification has not been incorporated into the diagram.

\section{Crystallography}

There are no intermetallic compounds in the system uranium-vanadium.

\section{References}

(1) Saller, H. A., and Rough, F. A. " "Vanadium-Uranium Constitutional Diagram", J. Metals, 15, 545-548 (April, 1953).

(2) Seybolt, A. U., and Sumsion, H. T., "Vanadium-Oxygen Solid Solutions", J. Metals, 5, 292-299 (February, 1953).

(3) McCaldin, J. O., and Duwez, Pol, "Allotropic Transformations at High Temperature", J. Metals, $\underline{6}, 619-20$ (May, 1954).

\section{URANIUM-YTTERBIUM}

Uranium and ytterbium show little miscibility in the liquid state. The solubility of ytterbium in liquid uranium is reported to be $0.15 \mathrm{w} / \mathrm{o}$ at $1150 \mathrm{C}$ and $0.2 \mathrm{w} / \mathrm{o}$ at $1250 \mathrm{C}$, while uranium solubility in ytterbium is essentially nil at $1000 \mathrm{C}$ and $0.8 \mathrm{w} / 0$ at $1250 \mathrm{C}$.

\section{Crystallography}

Data concerning the possibility of compounds in this system are not available.

\section{Reference}

(1) Wilhelm, H. A., "Nuclear Fuels Newsletter", WASH-704 (December, 1957). Classified.

\section{URANIUM-YTTRIUM}

Uranium and yttrium exhibit an immiscibility gap in the liquid state. Solubility of yttrium in liquid uranium is reported to increase from $0.075 \mathrm{w} / 0$ at $1150 \mathrm{C}$ to $0.15 \mathrm{w} / \mathrm{o}$ at $1250 \mathrm{C}^{(1)}$.

\section{Crystallography}

Nothing is known concerning the possibility of compounds in this system.

\section{$\underline{\text { Reference }}$}

(1) Wilhelm, H. A., "Nuclear Fuels Newsletter", WASH-704 (December, 1957). Classified. 


\section{URANIUM-ZINC}

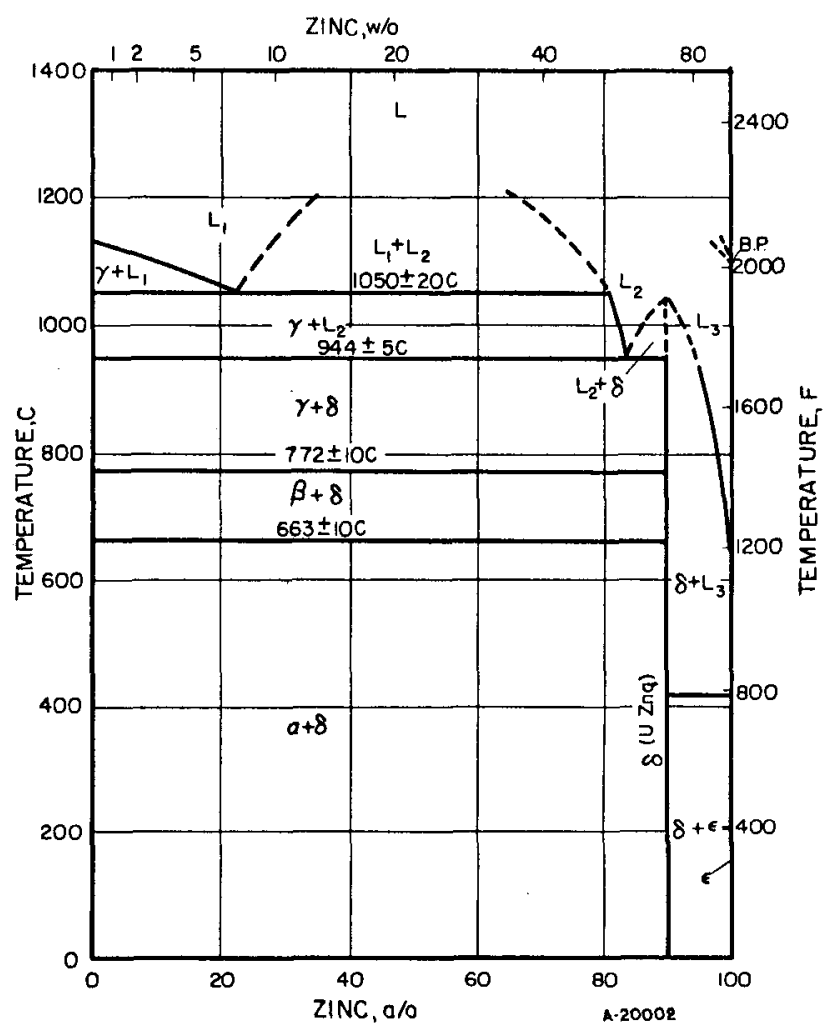

\section{The Constitutional Diagram}

The constitution of uranium-zinc alloys has been determined by Chiotti, Klepfer, and Gill(1) from X-ray, metallographic, thermal, and vapor-pressure data. The diagram shown is the one determined at 5 -atm pressure.

The solubility of zinc in uranium is very low, undetectable by the experimental methods employed. Solubilities of uranium in zinc at various temperatures are given below:

\begin{tabular}{cl} 
Temperature, $C$ & Uranium,w/o \\
\hline 419 & 0.025 \\
450 & $0.20 \bullet 0.1$ \\
500 & $0.28 \pm 0.01$ \\
550 & $0.30 \pm 0.08$ \\
600 & $0.45 \pm 0.02$ \\
650 & $1.3 \pm 0.2$ \\
700 & $3.1 \pm 0.3$
\end{tabular}

At $910 \mathrm{C}$ the solubility of uranium in zinc was calculated to be 14.6 a/o uranium.

The diagram shown is identical up to $910 \mathrm{C}$ to the one determined at 1 -atm pressure. Under the lower pressure condition, zinc boils at $910 \mathrm{C}$ and the compound $\mathrm{UZn}_{9}$ decomposes at $945 \pm 3 \mathrm{C}$ to the zinc vapor and liquid of approximate eutectic composition. Above $947 \mathrm{C}$, zinc vapor and the uranium gamma and liquid phases exist in equilibrium.

\section{Crystallography}

Only one compound forms in this system, analytical and metallographic data indicating a composition of $U \mathrm{Zn}_{9}$. The compound is believed to be hexagonal. 


\begin{tabular}{|c|c|c|c|c|c|c|c|}
\hline \multirow[b]{3}{*}{ Phase } & \multicolumn{3}{|c|}{ Unit Cell } & \multirow{2}{*}{\multicolumn{2}{|c|}{$\begin{array}{l}\text { Density, } \\
\mathrm{gm} / \mathrm{cm}^{3}\end{array}$}} & \multirow{3}{*}{$\begin{array}{l}\text { Space } \\
\text { Group }\end{array}$} & \multirow[b]{3}{*}{ Remarks } \\
\hline & & Dimensions, & $\begin{array}{c}\text { Number } \\
\text { of }\end{array}$ & & & & \\
\hline & Type & $\mathrm{A}$ & Molecules & X-Ray & Other & & \\
\hline $\begin{array}{l}\text { Delta } \\
\quad\left(\mathrm{UZn}_{\mathrm{q}}\right)\end{array}$ & Hexagonal & $\begin{array}{l}a=8.99 \\
c=8.98\end{array}$ & & & & $96 / \mathrm{mmr}$ & \\
\hline
\end{tabular}

\section{Reference}

(1) Chiotti, P., Klepfer, H. H., and Gill, K. J., "Uranium-Zinc System", J. Metals, 9, 51-57 (January, 1957).

\section{URANIUM-ZIRCONIUM}

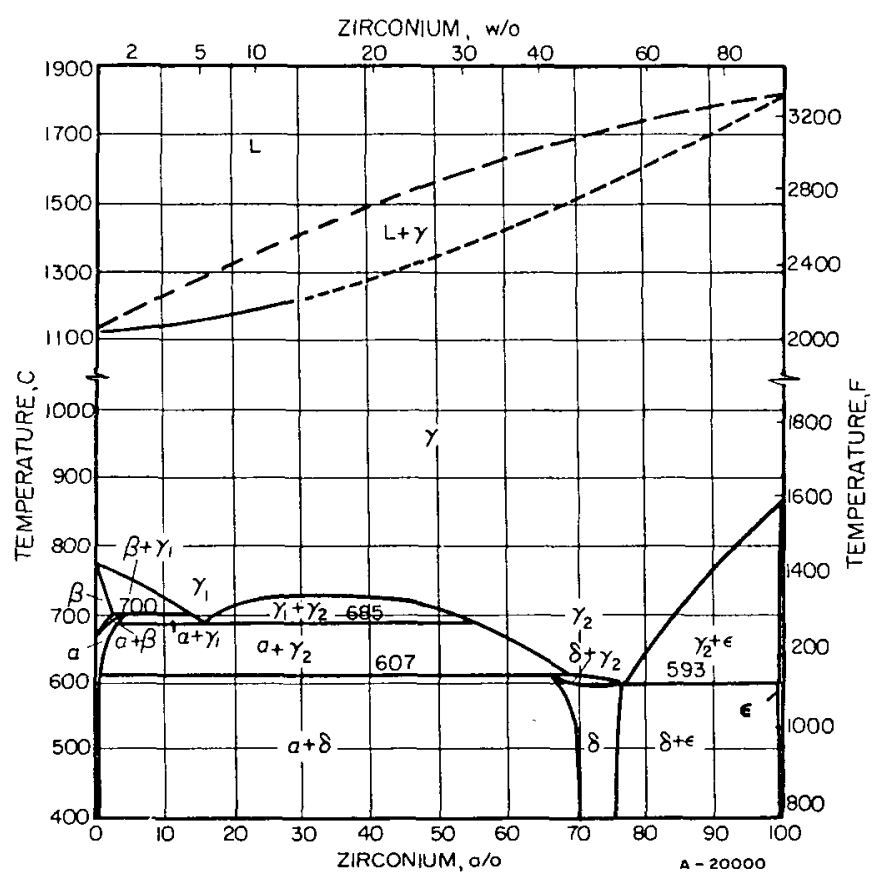

The Constitutional Diagram

The system uranium-zirconium has been studied by a number of investigators. The diagram shown is based largely on the work of Saller (1) and Rough(2), but the principal features of the system were reported earlier by Kaufmann(3) and Peterson(4). The diagram is based on work with alloys prepared by arc melting selected biscuit uranium and Grade I crystal-bar zirconium.

There is agreement that complete solid solution exists between gamma uranium and beta zirconium $(1,2,3,4,5,6)$, but the re was some question concerning the stability of the intermediate epsilon phase. However, results of studies by Bauer(2), Kearns (7), and Holden ${ }^{(8)}$ confirm the stability of the phase. Oxygen and nitrogen, in ternary alloy combination with the delta phase, have been shown (2) to cause its decomposition. Features shown in this region of the diagram are based upon the work of Rough, Austin, Bauer, and Doig(2). However, fairly wide variations in the solubility range of the delta phase have been reported. $(7,9,10)$ Knapton $(9)$ reports that delta forms peritectoidally at $620 \mathrm{C}$ and $63 \mathrm{a} / \mathrm{o}$ zirconium, giving a solubility range of 63 to $79.5 \mathrm{a} / 0$ zirconium at $600 \mathrm{C}$ and a solubility range of 66 to 79 a/o zirconium at $500 \mathrm{C}$. Studies in this region are complicated by the pronounced effect of oxygen and nitrogen on the delta-phase solubility limits and by the nature of the gamma-to-delta transformation in this region. Thus, supersaturated 
delta forms during low-temperature annealing of initially gamma-quenched alloys containing from about 50 to 90 a/o zirconium. Rejection of either alpha uranium or alpha zirconium from the supersaturated delta phase to yield the equilibrium delta composition occurs during subsequent heat treatment at temperatures below $600 \mathrm{C}$, the rate of rejection decreasing rapidly with temperature and in compositions close to the delta-phase composition limits. (1I)

The gamma-plus-epsilon region of the diagram has been studied by several investigators $(1,2,3,4,5,12)$, and variations in the gamma boundary values have been explained $(2,13)$ as arising from oxygen and nitrogen contamination. The value of solubility of uranium in alpha zirconium $(0.3 \mathrm{a} / \mathrm{o})$ at the isotherm was determined by McGeary $(12)$ and was based on precision dilatometric measurements of a series of alloys.

The general features of the high-uranium end of the system have been confirmed by a number of investigators. $(1,3,4,5,14)$ Refinement of this area to include the gamma I $^{-}$ plus-gamma 2 region is indicated by the more recent works. $(1,5)$ The details shown are based largely on the work of Saller, Rough, and Bauer(1), who have employed quantitative lineal analysis of metallographic samples, metallography, thermal analysis, and more recently high-temperature X-ray techniques (15) to establish the phase regions. However, Summers-Smith disagrees, reporting ${ }^{(5)}$ dilatometric and high-temperature X-ray evidence for a beta-plus-gamma field extending to 62 a/o zirconium in the temperature range 662 to $693 \mathrm{C}$, there being no alpha-plus-gamma ${ }_{1}$ field.

The solubility of zirconium in beta uranium is reported by Summers-Smith(5) as $2.5 \mathrm{a} / \mathrm{o}$ and in alpha uranium as $1.5 \mathrm{a} / \mathrm{o}$. Saller(1) reports values of about 3 and 5 a/o for maximum solubility, with solubility decreasing rapidly to less than 1 a/o below $660 \mathrm{C}$. Zegler(16) gives values between 0.5 and 1 a/o at 675,700 , and $750 \mathrm{C}$ in the beta phase; between 0.25 and $0.5 \mathrm{a} / 0$ from 500 to $640 \mathrm{C}$; and slightly in excess of $0.5 \mathrm{a} / 0$ at $660 \mathrm{C}$ in the alpha phase.

\section{Crystallography}

The delta phase was reported by Holden to be an ordered structure, and subsequently large unit cells based on the gamma-uranium structure were reported, giving a $=10.678 \mathrm{~A}(17)$ and $10.69 \mathrm{~A}(18)$. However, indexing is not altogether satisfactory, certain reflections having parameters slightly off the values necessary for a cubic structure. Therefore, Rough $(2)$ suggested a hexagonal or rhombohedral pseudo-cubic structure with a $=8.793$ and $c=9.212$ at $575 \mathrm{C}$ in a 72 a/o alloy. Adam (19) suggested that the discrepancies may arise from stacking faults; the delta-phase structure is strongly polarizing under a microscope, and a cubic structure is unlikely. Silcock $(20)$ and, more recently, Boyko(21) and Mueller $(22)$ determined the structure to be primitive hexagonal, accounting well for both the positions and intensities of the lines. This structure is partially ordered, with zirconium atoms located at the $0,0,0$, position while zirconium and uranium atoms are located randomly at the $1 / 3,2 / 3,1 / 2$ and $2 / 3,1 / 3,1 / 2$ positions. The random distribution of uranium and zirconium atoms allows a considerable range in composition. Silcock(20) and Boyko(21) report similar data for the phase as given below.

\begin{tabular}{|c|c|c|c|c|c|c|c|}
\hline \multirow[b]{3}{*}{ Phase } & \multicolumn{3}{|c|}{ Unit Cell } & & & \multirow{3}{*}{$\begin{array}{l}\text { Space } \\
\text { Group }\end{array}$} & \multirow[b]{3}{*}{ Remarks } \\
\hline & & Dimensions, & $\begin{array}{c}\text { Number } \\
\text { cf }\end{array}$ & $\begin{array}{l}\text { Den } \\
\mathrm{gm} /\end{array}$ & $\mathrm{m}^{3}$ & & \\
\hline & Type & $\mathrm{A}$ & Molecules & $\underline{X-R a y}$ & Other & & \\
\hline $\begin{array}{l}\text { Delta } \\
\qquad\left(U Z_{2}\right)\end{array}$ & Hexagonal & $\begin{array}{l}a=5.03 \\
c=3.08\end{array}$ & 1 & & 9.7 & $\mathrm{P} 6 / \mathrm{mmm}$ & $\begin{array}{l}\text { Partially dis- } \\
\text { ordered } \\
\text { C32-type } \\
\mathrm{AlB}_{2} \\
\text { structure }\end{array}$ \\
\hline
\end{tabular}

$\underline{\text { References }}$

(1) Saller, H. A., Rough, F. A., and Bauer, A. A. , private communication (1954).

(2) Rough, F. A., Austin, A. E., Bauer, A. A., and Doig, J. R., "The Stability and Existence Range of the Zirconium-Uranium Epsilon Phase", BMI-1092 (May 28, 1956 ). 
(3) Kaufmann, A. R., Technical Progress Report, MIT-1078 (April, 1952).

(4) Carlson, O. N., and Peterson, D., "Some Studies of the Uranium-Thorium-Zirconium Ternary Alloys System", AECD-3206 (June 5, 1950).

(5) Summers-Smith, D., "The Constitution of Uranium-Zirconium Alloys", J. Inst. Metals, 83 (February, 1955).

(6) Kalish, N. S. , unpublished information (1953).

(7) Kearns, J. , unpublished information (1956).

(8) Holden, A. N., and Seymour, W. E., "The Uranium-Zirconium System", Trans. AIME, 209, 515 (1957).

(9) Knapton, A. G. , United Kingdom, unpublished information (1957).

(10) Duffey, J. F., and Bruch, C. A., "The Delta Phase Field of the Uranium-Zirconium Equilibrium Diagram", submitted to AIME for publication (1957).

(11) Bauer, A. A., private communication (1957).

(12) McGeary, R. K., "Dilatometric Investigation of Zirconium, Zirconium-Uranium, Zirconium-Oxygen, and Zirconium-Nitrogen Alloys", WAPD-36 (July, 1951).

(13) Bauer, A. A., Beatty, G. H., and Rough, F. A., "The Constitution of ZirconiumUranium Alloys Containing Oxygen or Nitrogen", BMI- 187 (May, 1957).

(14) Buzzard, R. W., Liss, R. B., and Fickle, D. P., "The Uranium-Zirconium Binary System", J. Met. and Cer., TID-2002 (August, 1952).

(15) Bauer, A. A., and Austin, A. E., private communication (1956).

(16) Zegler, S. T., and Lloyd, L. T., Quarterly Report (Metallurgy Division), ANL-5489, 44-50 (March, 1956).

(17) Peterson, D. , Quarterly Summary Research Report in Metallurgy, ISC-575 (July, 1955 ).

(18) Mueller, M. H., "The Delta Phase Found in U-Zr Alloys", Acta Cryst. , 8, 849-50 (1955).

(19) Adam, J., United Kingdom, unpublished information (1957).

(20) Silcock, J. M., Trans. AIME, 209, 521 (1957).

(21) Boyko, E. R., "The Structure of the Phase in the Uranium-Zirconium System", Acta Cryst., 10, 712 (1957).

(22) Mueller, M. H. Knott, H. W., and Heaton, L., "The Hexagonal Phase Found in Certain Zirconium and Titanium Alloys", Preserited at the 15th Pittsburgh Diffraction Conference (November 7, 1957). 


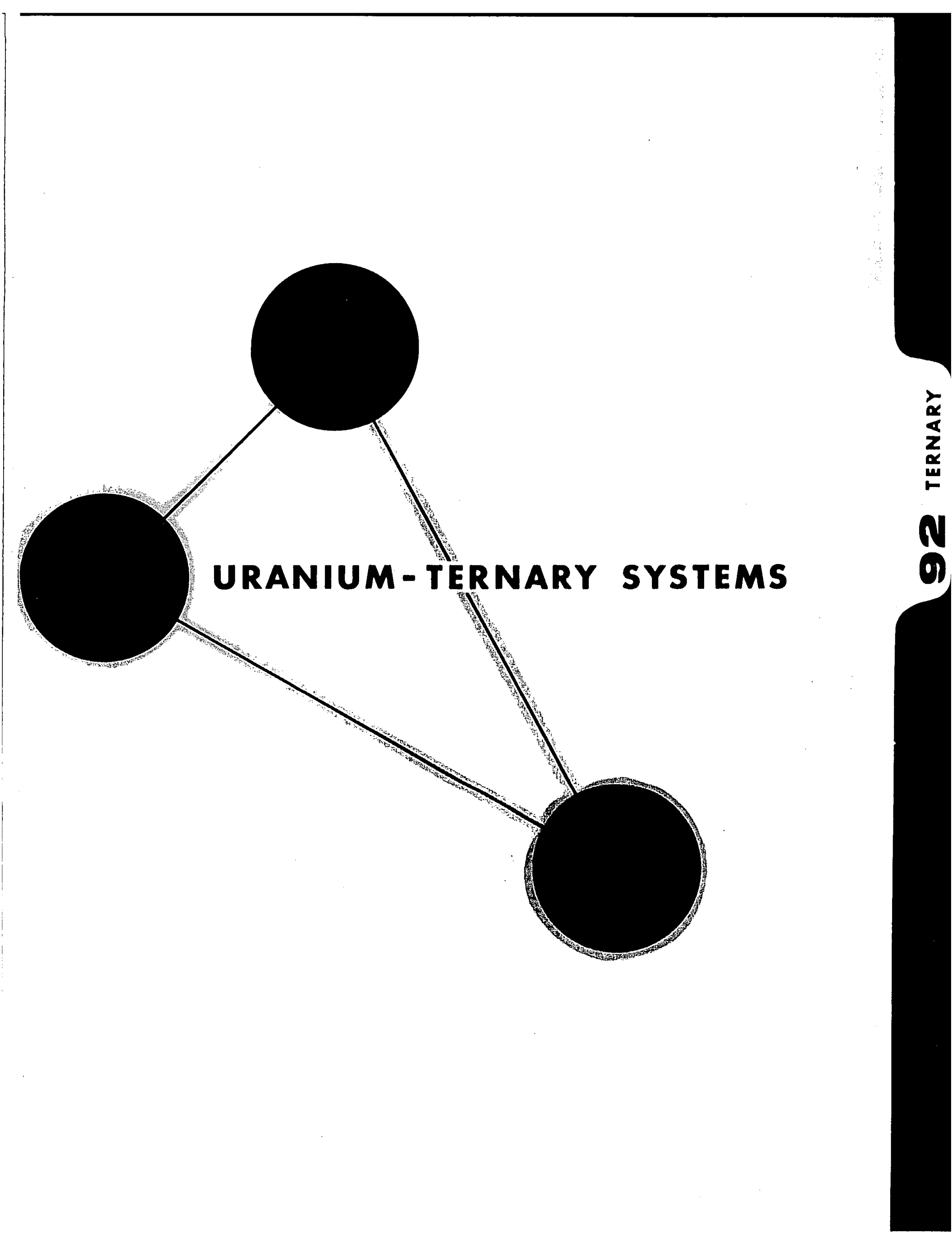




\title{
URANIUM-ALUMINUM-SILICON
}

\begin{abstract}
The region of the system which has been studied includes $\mathrm{UAl}_{4}, \mathrm{UAl}_{3}$, silicon, and uranium(1), but no diagram is available.

It is reported that $0.8 \mathrm{w} / 0$ silicon is sufficient to suppress the formation of $\mathrm{UAl}_{4}$ entirely with a content of $20 \mathrm{w} / 0$ uranium. The phases in equilibrium then appear to be $\mathrm{UAl}_{3}$, silicon, and aluminum(1). However, the addition of up to $1 \mathrm{w} / 0$ silicon to alloys containing 40 and $50 \mathrm{w} / \mathrm{o}$ uranium was studied and found to depress the UAl 4 peritectic temperature to about $703 \mathrm{C}$, but apparently does not eliminate the phase. No noticeable effect of these additions on the liquidus of alloys in this range was observed ${ }^{(2)}$.
\end{abstract}

The lattice constant of $\mathrm{UAl}_{3}$ is altered by partial replacement of the aluminum atoms by silicon atoms. The composition $\mathrm{U}\left(\mathrm{Al}_{0} 0.96 \mathrm{Si} 0.04\right)_{3}$ represents the average replacement, though actual replacement appears to be a function of temperature. No uranium was observed to be soluble in the aluminum and silicon phases; hence, the mutual solubilities of aluminum and silicon are unchanged.

No change could be detected either in the aluminum-silicon(1) or aluminum-rich uraniumaluminum $^{(2)}$ eutectic temperatures.

Crystallography

No new phases are reported.

$\underline{\text { References }}$

(1) Boyle, E. J., unpublished information (February, 1951).

(2) Storhok, V. W., and Bauer, A. A., private communication (1958).

\section{URANIUM-ALUMINUM-THORIUM}

\author{
The aluminum-rich corner of this system has been studied. (1) The data indicate a \\ ternary eutectic in the neighborhood of $76 \mathrm{w} / \mathrm{o}$ aluminum, $18 \mathrm{w} / \mathrm{o}$ to thorium, and $6 \mathrm{w} / \mathrm{o}$ \\ uranium. The products of the eutectic decomposition are thought to be aluminum, $\mathrm{UAl}_{3}$, and \\ $\mathrm{ThAl}_{3}$. \\ Crystallography
}

No compounds not appearing in the binary system were detected.

\section{Reference}

(1) Bobeck, G. E., and Wilhelm, H. A., "Alloys of Aluminum, Thorium, and Uranium", ISC-832 (December, 1956). 


\section{URANIUM-BERYLLIUM-CARBON}

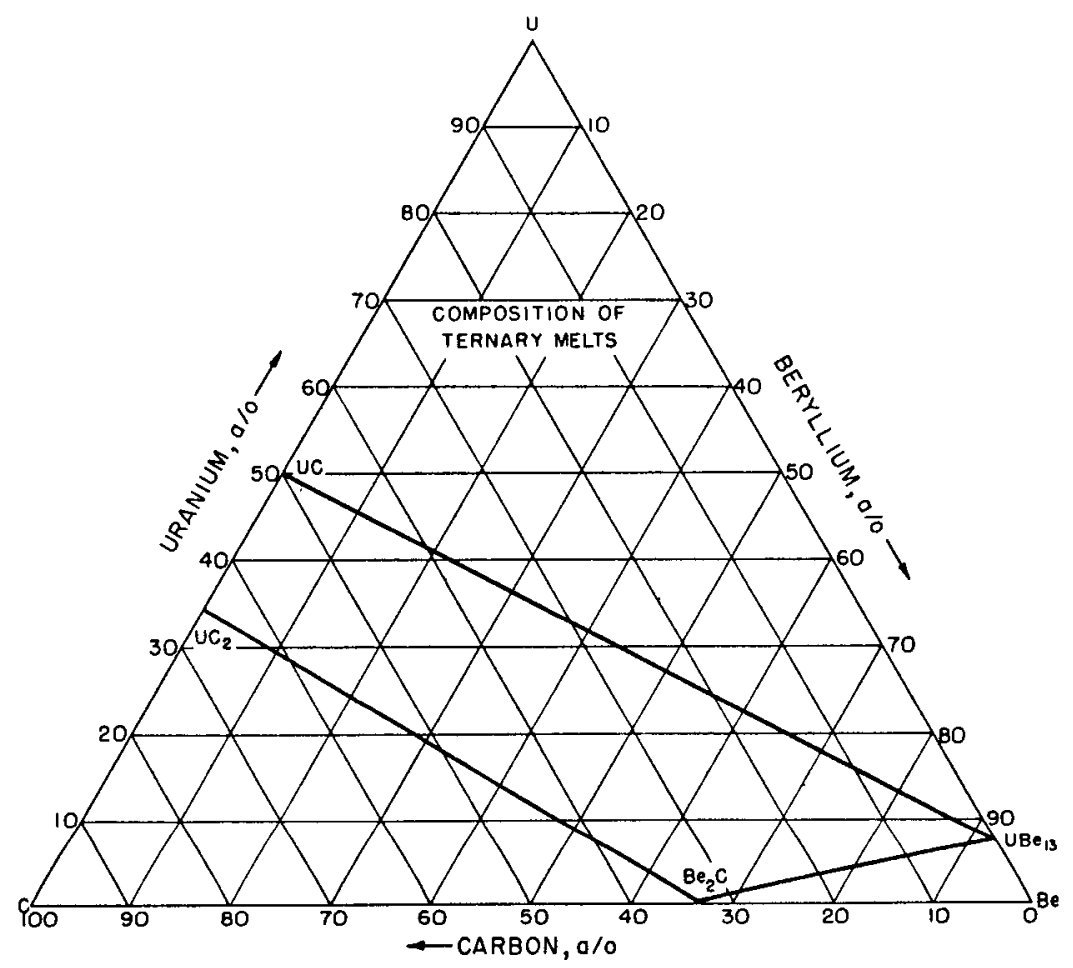

The Constiturional Diagram

A trapezoidal region, outlined in the diagram, has been studied. (1) No new phases were discovered in this area of the system. It is uncertain whether an additional line dividing the trapezoid into triangles should be drawn between $\mathrm{UC}$ and $\mathrm{Be}_{2} \mathrm{C}$ or between $\mathrm{UC}_{2}$ and $\mathrm{UBe}_{13}$.

The analyzed compositions of the alloys and results of examination by $\mathrm{X}$-ray diffraction are given below. The system has also been studied at the National Bureau of Standards, but the resulting data were not available.for publication.

Composition, a/o

\begin{tabular}{|c|c|c|c|}
\hline \multicolumn{3}{|c|}{ Composition, a/o } & \multirow{2}{*}{ Identified } \\
\hline $\mathrm{U}$ & $\mathrm{C}$ & $\mathrm{Be}$ & \\
\hline 10.8 & 22.1 & 67.2 & $\mathrm{UC}-\mathrm{Be}_{13} \mathrm{U}$ \\
\hline 8.4 & 32.5 & 59.1 & $\mathrm{UC}+\mathrm{UC}_{2}$ \\
\hline 21.2 & 40.3 & 38.4 & UC \\
\hline 5.5 & 32.0 & 62.5 & $\mathrm{UC}+\mathrm{Be}_{2} \mathrm{C}$ \\
\hline 21.9 & 29.9 & 48.2 & $\mathrm{UC}+\mathrm{Be}_{13} \mathrm{U}$ \\
\hline 27.5 & 35.0 & 37.5 & $\mathrm{UC}+\mathrm{UC}_{2}$ \\
\hline 11.0 & 41.8 & 47.1 & $\mathrm{UC}_{2}$ \\
\hline 21.3 & 42.2 & 36.5 & $\mathrm{UC}_{2}$ \\
\hline 28.7 & 49.4 & 21.9 & $\mathrm{UC}_{2}+\mathrm{UC}$ \\
\hline 34.8 & 60.8 & 4.4 & $\mathrm{UC}_{2}$ \\
\hline
\end{tabular}




\section{Crystaliography}

No new phases have been reported.

\section{Reference}

(1) Kaufmann, A. R., Kulin, P. A., and Allen, L. R., unpublished information (1949).

\section{UR ANIUM-BISMÚTH-LEAD}

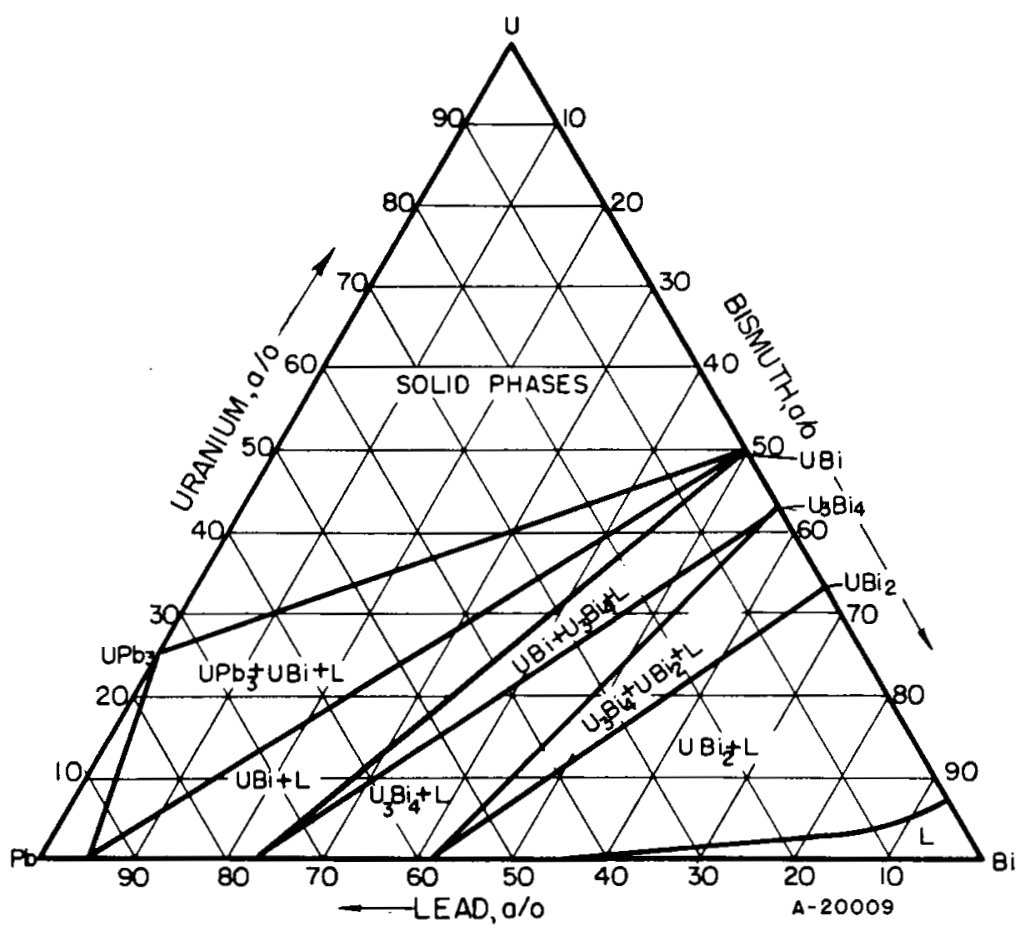

The Constitutional Diagram

A portion of the uranium-bismuth-lead system has been studied by Teitel ${ }^{(1)}$. The $800 \mathrm{C}$ isothermal section shown (2) represents a revision of this work to include the recently identified $\mathrm{U}_{3} \mathrm{Bi}_{4}$ phase.

It is seen that the three uranium-bismuth compounds exist in equilibrium with liquid phases containing up to about 95 a/o lead. The UPb 3 phase exists in equilibrium with UBi and liquid containing less than 5 a/o bismuth.

\section{Crystallography}

No new phases have been reported.

\section{References}

(1) Teitel, R. J., Kammerer, O. F., and Gurinsky, D. H., unpublished information (August 31, 1951).

(2) Teitel, R. J., and Bryner, J. S., private communication (1956). 


\section{URANIUM-BISMUTH-TIN}

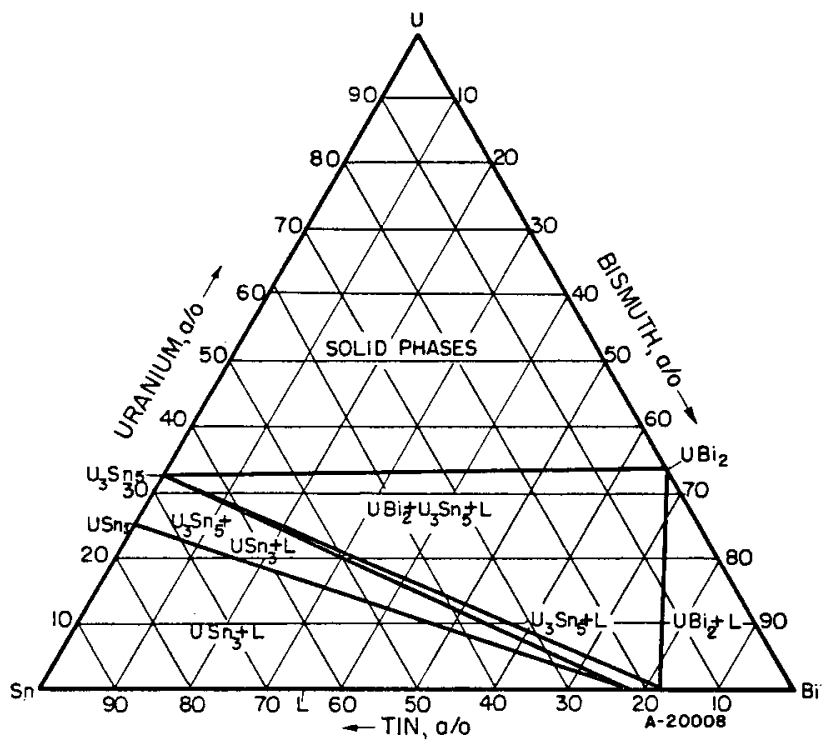

The Constitutional Diagram

The portion of the diagram shown is from Teitel(l) and is drawn for a temperature of $350 \mathrm{C}$.

Tin lowers the solubility of uranium in the liquid phase. The tin compounds exist in equilibrium with liquids containing less than 82 a/o bismuth.

\section{Crystallography}

No new phase has been reported.

\section{Reference}

(1) Teitel, R. J., private communication (1956).

\section{UR ANIUM-COB ALT-NICKEL}

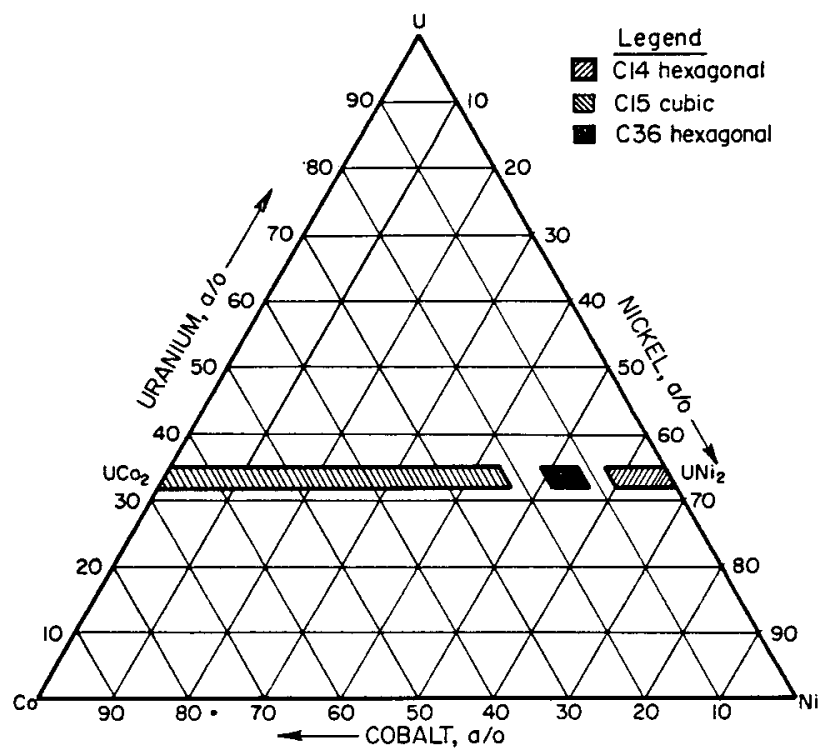




\section{The Constitutional Diagram}

The pseudo binary $\mathrm{UCo}_{2}-\mathrm{UNi}_{2}$ has been studied ${ }^{(1)}$. The compound $\mathrm{UCo}_{2}$ has the C15type structure while the compound $\mathrm{UNi}_{2}$ has the $\mathrm{C} 14$-type structure. Isotherms at 700 and $900 \mathrm{C}$ show similar phase fields. The diagram shown is for $900 \mathrm{C}$. An intermediate phase $\mathrm{X}$ occurs with the C36-type structure, and in some alloys an additional pattern was observed. Work with single crystals showed the pattern to be the result of a large c-spacing. The structure could not be reproduced in samples of the same nominal composition.

Solubility limits are given as:

\begin{tabular}{|c|c|c|c|c|}
\hline & \multicolumn{2}{|c|}{$900 \mathrm{C}$} & \multicolumn{2}{|c|}{$700 \mathrm{C}$} \\
\hline & Nickel, a/o & Cobalt, a/o & Nickel, a/o & Cobalt, a/o \\
\hline $\mathrm{UNi}_{2} /\left(\mathrm{UNi}_{2}+\mathrm{X}\right)$ & 58.5 & 8.2 & 56.3 & 10.4 \\
\hline $\mathrm{X} /\left(\mathrm{UNi}_{2}+\mathrm{X}\right)$ & 55.6 & 11.1 & 55.6 & 11.1 \\
\hline $\mathrm{X} /\left(\mathrm{X}+\mathrm{UCo}_{2}\right)$ & 50.7 & 16.0 & 50.7 & 16.0 \\
\hline $\mathrm{UCo}_{2} /\left(\mathrm{X}+\mathrm{UCo}_{2}\right)$ & 45.3 & 21.4 & 45.2 & 21.5 \\
\hline
\end{tabular}

Crystallography

The structure of $\mathrm{UCo}_{2}$ and $\mathrm{UNi}_{2}$ has been given by Baenziger (2), but for consistency, all the parameters here, including that of the $\mathrm{X}$-phase are taken from Brooks $(1)$.

\begin{tabular}{|c|c|c|c|c|c|c|c|}
\hline \multirow[b]{3}{*}{ Phase } & \multicolumn{3}{|c|}{ Unit Cell } & & & \multirow{3}{*}{$\begin{array}{l}\text { Space } \\
\text { Group }\end{array}$} & \multirow[b]{3}{*}{ Remarks } \\
\hline & \multirow[b]{2}{*}{ Type } & \multirow{2}{*}{$\begin{array}{c}\text { Dimensions, } \\
\mathrm{A} \\
\end{array}$} & \multirow{2}{*}{$\begin{array}{c}\text { Number } \\
\text { of } \\
\text { Molecules } \\
\end{array}$} & \multicolumn{2}{|c|}{$\begin{array}{r}\text { Density, } \\
\mathrm{g} / \mathrm{cm}^{3} \\
\end{array}$} & & \\
\hline & & & & X-Ray & Other & & \\
\hline $\mathrm{UCo}_{2}$ & $\mathrm{Fcc}$ & $a=7.0051$ & 8 & 13.8 & & $\mathrm{Fd} 3 \mathrm{~m}$ & $\begin{array}{l}\mathrm{Cl} 15 \mathrm{MgCu}_{2} \\
\text { structure }\end{array}$ \\
\hline $\mathrm{UNi}_{2}$ & Hexagonal & $\begin{array}{l}a=4.959 \\
c=8.245\end{array}$ & 4 & 13.5 & & $\mathrm{P}_{3} / \mathrm{mmc}$ & $\begin{array}{l}\mathrm{C} 14 \mathrm{MgZn}_{2} \\
\text { structure }\end{array}$ \\
\hline $\mathrm{x}$ & Hexagonal & $\begin{array}{l}a=4.963 \\
c=16.395\end{array}$ & 8 & -- & & $\mathrm{P}_{3} / \mathrm{mmc}$ & $\begin{array}{r}\mathrm{C} 36 \mathrm{MgNi}_{2} \\
\text { structure }\end{array}$ \\
\hline
\end{tabular}

\section{References}

(1) Brooks, G. B., Williams, G. I., and Smith, E. A., "Pseudo-Binary Phase Sections Between Laves Phases in Ternary Alloys of Uranium", J. Inst. Met., 83, 271 (1954-55).

(2) Baenziger, N, C., Rundle, R. E., Snow, A. I., and Wilson, A. S., "Compounds of Uranium With the First Long Period" (AECD 2598), Acta Cryst., 3, 34 (1950). 


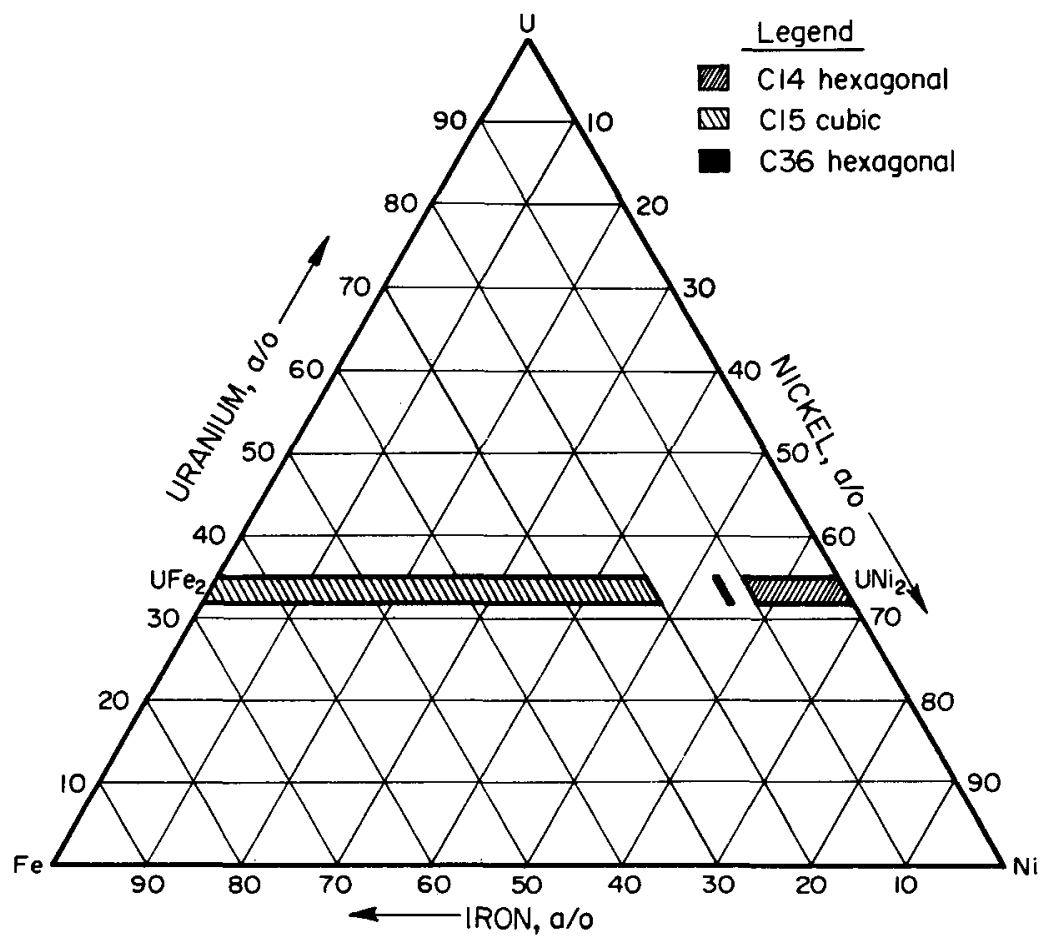

$A \cdot 26952$

The Constitutional Diagram

The pseudo binary $\mathrm{UFe}_{2}-\mathrm{UNi}_{2}$ has been studied ${ }^{(1)}$. The compound $\mathrm{UFe}_{2}$ has the C15type structure while the compound $\mathrm{UNi}_{2}$ has the C14-type structure. Isotherms at 700 and $900 \mathrm{C}$ show similar phase fields. The diagram shown is for $900 \mathrm{C}$. An intermediate phase $\mathrm{X}$ occurs with the C36-type structure.

Solubility limits are given as:

\begin{tabular}{|c|c|c|c|c|}
\hline & & & & \\
\hline & Nickel, a/o & Iron, a/o & Nickel, a/o & Iron, a/o \\
\hline $\mathrm{UNi}_{2} /\left(\mathrm{UNi}_{2}+\mathrm{X}\right)$ & 56.9 & 9.8 & 56.7 & 10.0 \\
\hline $\mathrm{X} /\left(\mathrm{UNi}_{2}+\mathrm{X}\right)$ & 54.5 & 12.2 & 54.5 & 12.2 \\
\hline $\mathrm{X} /\left(+\mathrm{UFe} e_{2}\right)$ & 53.9 & 12.8 & 53.9 & 12.8 \\
\hline $\mathrm{UFe}_{2} /\left(+\mathrm{UFe}_{2}\right)$ & 47.7 & 19.9 & 47.6 & 19.1 \\
\hline
\end{tabular}

\section{Crystallography}

The structure of $\mathrm{UCo}_{2}$ and $\mathrm{UNi}_{2}$ has been given by Baenziger(2), but for consistency, all the parameters here, including that of the $X$-phase are taken from Brooks $(1)$.

\begin{tabular}{|c|c|c|c|c|c|c|c|}
\hline \multirow[b]{3}{*}{ Phase } & \multicolumn{3}{|c|}{ Unit Cell } & \multirow{2}{*}{\multicolumn{2}{|c|}{$\begin{array}{c}\text { Density, } \\
\text { g/ } / \mathrm{cm}^{3}\end{array}$}} & \multirow{3}{*}{$\begin{array}{l}\text { Space } \\
\text { Group }\end{array}$} & \multirow[b]{3}{*}{ Remarks } \\
\hline & & Dimensions, & $\begin{array}{c}\text { Number } \\
\text { of }\end{array}$ & & & & \\
\hline & Type & $\mathrm{A}$ & Molecules & X-Ray & Other & & \\
\hline $\mathrm{UFe}_{2}$ & $F_{c c}$ & $a=7.065$ & 8 & 12.5 & -- & $\mathrm{Fd} 2 \mathrm{~m}$ & $\begin{array}{c}\mathrm{C} 15 \mathrm{MgCu}_{2} \\
\text { structure }\end{array}$ \\
\hline $\mathrm{UNi}_{2}$ & Hexagonal & $\begin{array}{l}a=4.959 \\
c=8.245\end{array}$ & 4 & 13.5 & -- & $\mathrm{P}_{3} / \mathrm{mmc}$ & $\begin{array}{l}\mathrm{C} 14 \mathrm{MgZn}_{2} \\
\text { structure }\end{array}$ \\
\hline$x$ & Hexagonal & $\begin{array}{l}a=4.972 \\
c=16.425\end{array}$ & 8 & -- & -- & $\mathrm{Pb}_{3} / \mathrm{mmc}$ & $\begin{array}{r}\text { C36 } \mathrm{MgNi}_{2} \\
\text { structure }\end{array}$ \\
\hline
\end{tabular}




\section{References}

(1) Brooks, G. B., Williams, G. I., and Smith, E. A., "Pseudo-Binary Phase Sections Between Laves Phases in Ternary Alloys of Uranium", J. Inst. Met., 83, 271 (1954-55).

(2) Baenziger, N. C., Rundle, R. E., Snow, A. I., and Wilson, A. S., "Compounds of Uranium With the First Long Period" (AECD 2598) Acta Cryst., 3, 34 (1950).

\section{UR ANIUM-LEAD-TIN}

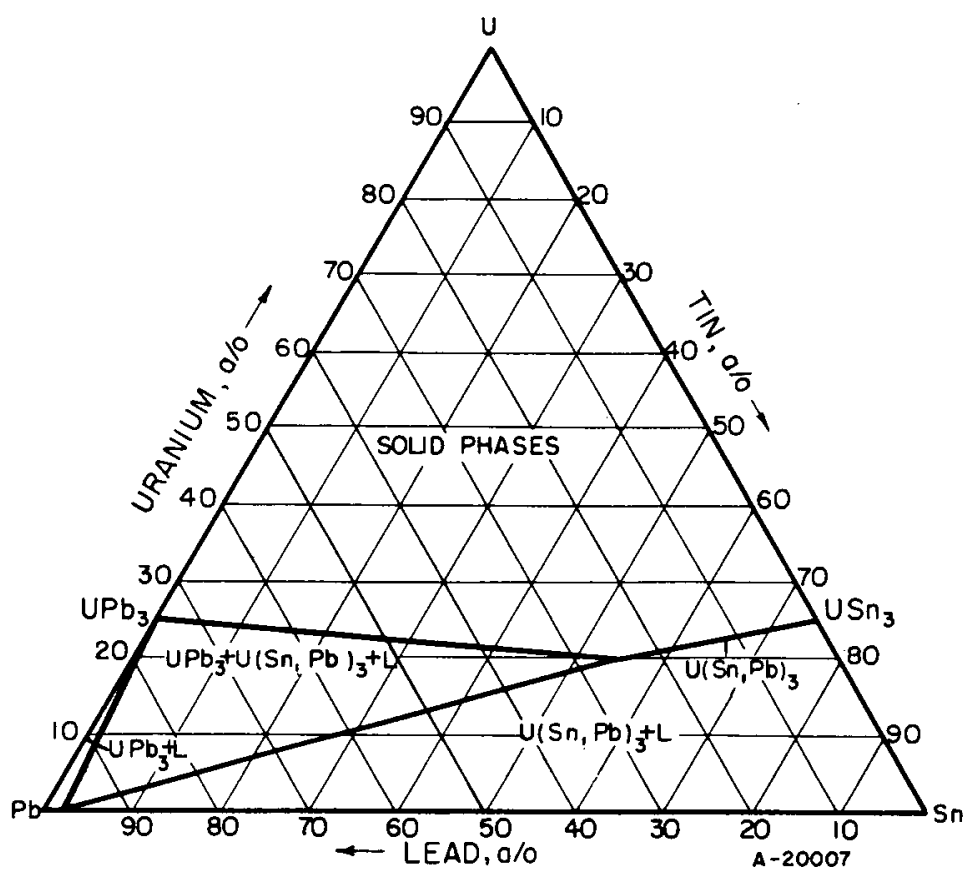

The Constitutional Diagram

The portion of the uranium-lead-tin system at $350 \mathrm{G}$ shown in the accompanying figure is from Teitel(1). Extensive solubility of lead in USn 3 is indicated.

The $\mathrm{U}(\mathrm{Sn}, \mathrm{Pb})_{3}$ phase exists in equilibrium with liquids containing up to 97.5 a $/ 0$ lead.

\section{Crystallography}

No new phases have been reported.

\section{Reference}

(1) Teitel, R. J., private communication (1956). 


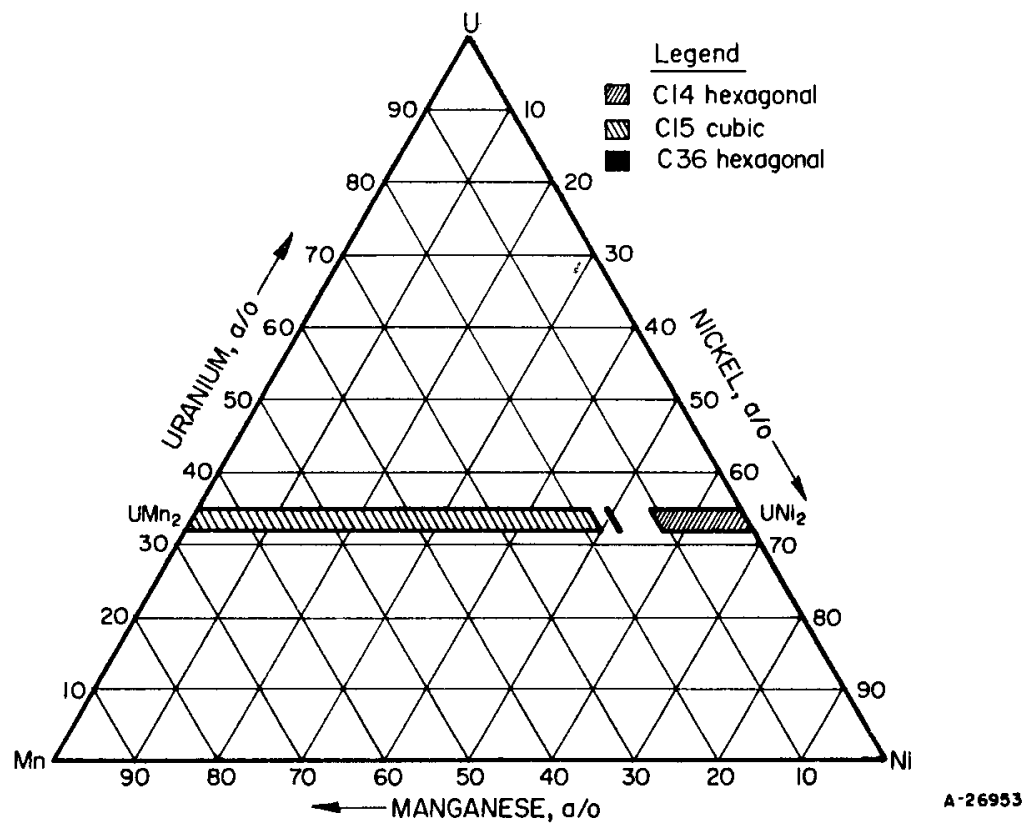

The Constitutional Diagram

The pseudo binary $\mathrm{UMn}_{2}-\mathrm{UNi}_{2}$ has been studied(1). The compound $\mathrm{UMn}_{2}$ has the C15type structure; the compound $\mathrm{UNi}_{2}$ has the Cl4-type structure. Isotherms at 900 and $700 \mathrm{C}$ show identical boundaries within experimental error, and are given in the diagram. An intermediate phase, $\mathrm{X}$, with the C36-type structure was observed. In one alloy, an additional pattern was observed; work with single crystals showed that the sample had a hexagonal cell and an abnormally large spacing. This latter structure could not be reproduced in other samples.

Solubility limits are given as:

\begin{tabular}{|c|c|c|c|c|}
\hline & \multicolumn{2}{|c|}{$900 \mathrm{C}$} & \multicolumn{2}{|c|}{$700 \mathrm{C}$} \\
\hline & Nickel, a/o & Manganese, a/o & Nickel, a/o & Manganese, a/o \\
\hline $\mathrm{UNi}_{2} /\left(\mathrm{UNi}_{2}+\mathrm{X}\right)$ & 55.9 & 10.7 & 55.9 & 10.7 \\
\hline $\mathrm{X} /\left(\mathrm{UNi}_{2}+\mathrm{X}\right)$ & 50.9 & 15.8 & 50.9 & 15.8 \\
\hline $\mathrm{X} /\left(\mathrm{X}+\mathrm{UMn}_{2}\right)$ & 50.5 & 16.2 & 50.5 & 16.2 \\
\hline $\mathrm{UMn}_{2} /\left(\mathrm{X}+\mathrm{UMn}_{2}\right)$ & 48.9 & 17.8 & 48.5 & 17.8 \\
\hline
\end{tabular}

Crystallography

The structure of $\mathrm{UCO}_{2}$ and $\mathrm{UNi}_{2}$ has been given by Baenziger( ${ }^{(2)}$, but the parameters given here are all from Brooks (1), including those of the intermediate phase, $\mathrm{X}$.

\begin{tabular}{|c|c|c|c|c|c|c|c|}
\hline \multirow[b]{3}{*}{ Phase } & \multicolumn{3}{|c|}{ Unit Cell } & & & \multirow{3}{*}{$\begin{array}{l}\text { Space } \\
\text { Group }\end{array}$} & \multirow[b]{3}{*}{ Remarks } \\
\hline & \multirow[b]{2}{*}{ Type } & \multirow{2}{*}{$\begin{array}{c}\text { Dimensions, } \\
\mathrm{A} \\
\end{array}$} & \multirow{2}{*}{ 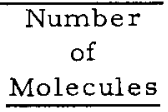 } & \multicolumn{2}{|c|}{$\begin{array}{l}\text { Density, } \\
\mathrm{g} / \mathrm{cm}^{3}\end{array}$} & & \\
\hline & & & & X-Ray & Other & & \\
\hline$\overline{\mathrm{UMn}_{2}}$ & Fcc & $a=7.156$ & 8 & 12.5 & - & $\mathrm{Fd} 3 \mathrm{~m}$ & $\begin{array}{l}\mathrm{C} 15, \mathrm{MgCu}_{2} \\
\text { structure }\end{array}$ \\
\hline $\mathrm{UNi}_{2}$ & Hexagonal & $\begin{array}{l}a=4.959 \\
c=8.245\end{array}$ & 4 & 13.5 & -- & $\begin{array}{l}\mathrm{C} 6 / \mathrm{mmc} \\
\mathrm{P}_{3} / \mathrm{mmc}\end{array}$ & $\begin{array}{c}\mathrm{Cl}^{4}, \mathrm{MgZn}_{2} \\
\text { structure }\end{array}$ \\
\hline $\mathrm{x}$ & Hexagonal & $\begin{array}{l}a=4.986 \\
c=16.453\end{array}$ & 8 & -- & -- & $\mathrm{P}_{3} / \mathrm{mmc}$ & $\begin{array}{c}\mathrm{C} 36, \mathrm{MgNi}_{2} \\
\text { structure }\end{array}$ \\
\hline
\end{tabular}




\section{References}

(1) Brooks, G. B., Williams, G. I., and Smith, E. A., "Pseudo-Binary Phase Sections Between Laves Phases in Ternary Alloys of Uranium", J. Inst. of Met., 83, 271 (1954-55).

(2) Baenziger, N. C., Rundle, R. E., Snow, A. I., and Wilson, A. S., "Compounds of Uranium With the First Long Period", (AECD 2598) Acta Cryst., 3, 34 (1950).

\section{URANIUM-MOLYBDENUM-NIOBIUM}

Data on the effect of molybdenum on the shape of the gamma 1 -plus-gamma 2 loop which occurs in binary uranium-niobium alloys is available ${ }^{(1)}$. Metallographic and X-ray results indicate that 5 a/o molybdenum increases the extent of the loop to 50 to 57 a/o niobium at $1100 \mathrm{C}, 30$ to $65 \mathrm{a} / 0$ niobium at $950 \mathrm{C}$, and 15 to $69 \mathrm{a} / 0$ niobium at $800 \mathrm{C}$. The monotectoid temperature in an alloy containing 5 a/o molybdenum and 25 a/o niobium is $647 \pm 3 \mathrm{C}$. No new phases have been observed at temperatures above $650 \mathrm{C}$.

\section{Crystallography}

No new phases have been reported.

\section{Reference}

(1) Bannister, G. H., and Murray, J. R., United Kingdom, unpublished work (1957).

\section{URANIUM-MOLYBDENUM-RUTHENIUM}

A study of the high-uranium portion of the system is reported(1). The addition of about 8 a/o ruthenium to uranium-molybdenum alloys reduces molybdenum solubility in the gamma phase to approximately $23 \mathrm{a} / \mathrm{o}$. At $660 \mathrm{C}$, the uranium-rich limit of the gamma phase occurs in an alloy containing about 4.5 a/o each of molybdenum and ruthenium. The gamma- and beta-uranium phases exist in equilibrium with $U_{2} R u$ at this temperature.

Crystallography

No new phases have been reported.

Reference

(1) Dwight, A. E., "Nuclear Fuels Newsletter", WASH-702 (May, 1957). Classified. 


\section{URANIUM-MOLYBDENUM-TITANIUM}

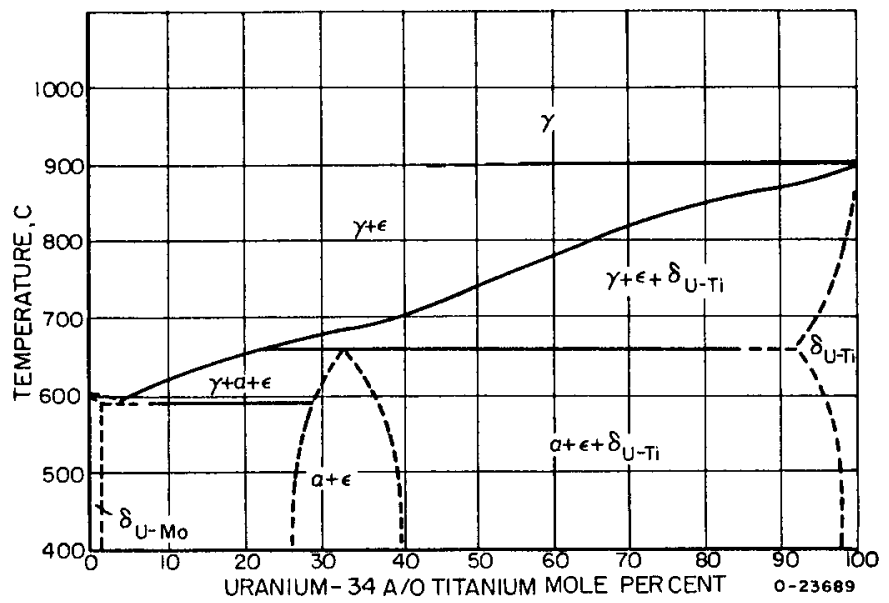

The Constitutional Diagram

An investigation of the region between the delta phases of the uranium-molybdenum and uranium-titanium systems has been conducted on alloys ranging in composition from uranium31.5 a/o molybdenum to uranium -34 a/o titanium (1). The tentative ternary cut shown is based upon metallographic, X-ray, and thermal-analysis data.

In the compositional range investigated the three components show complete solubility at elevated temperatures. The epsilon phase which appears in these alloys is a body-centered cubic solid solution rich in molybdenum and titanium. With the formation of the uraniumtitanium delta phase and with decreasing temperatures, the epsilon phase becomes depleted with respect to uranium; the gamma phase approaches the uranium-molybdenum eutectoid composition.

The absence of beta uranium in these alloys indicates that the equilibrium established between the gamma-uranium and uranium-titanium delta phases restricts the beta phase to high-uranium alloys. At lower temperatures, the equilibrium established between the alphauranium and epsilon phases restricts the delta-phase regions.

Ternary solubility of molybdenum and titanium in the respective delta phases is limited.

Crystallography

No new phases have been reported.

$\underline{\text { Reference }}$

(1) Saller, H. A., Rough, F. A., Bauer, A. A., and Doig, J. R., "Constitution of DeltaPhase Alloys of the System Uranium-Molybdenum-Titanium", BMI-1134 (September, 1956). 


\section{URANIUM-NIOBIUM-ZIRCONIUM}
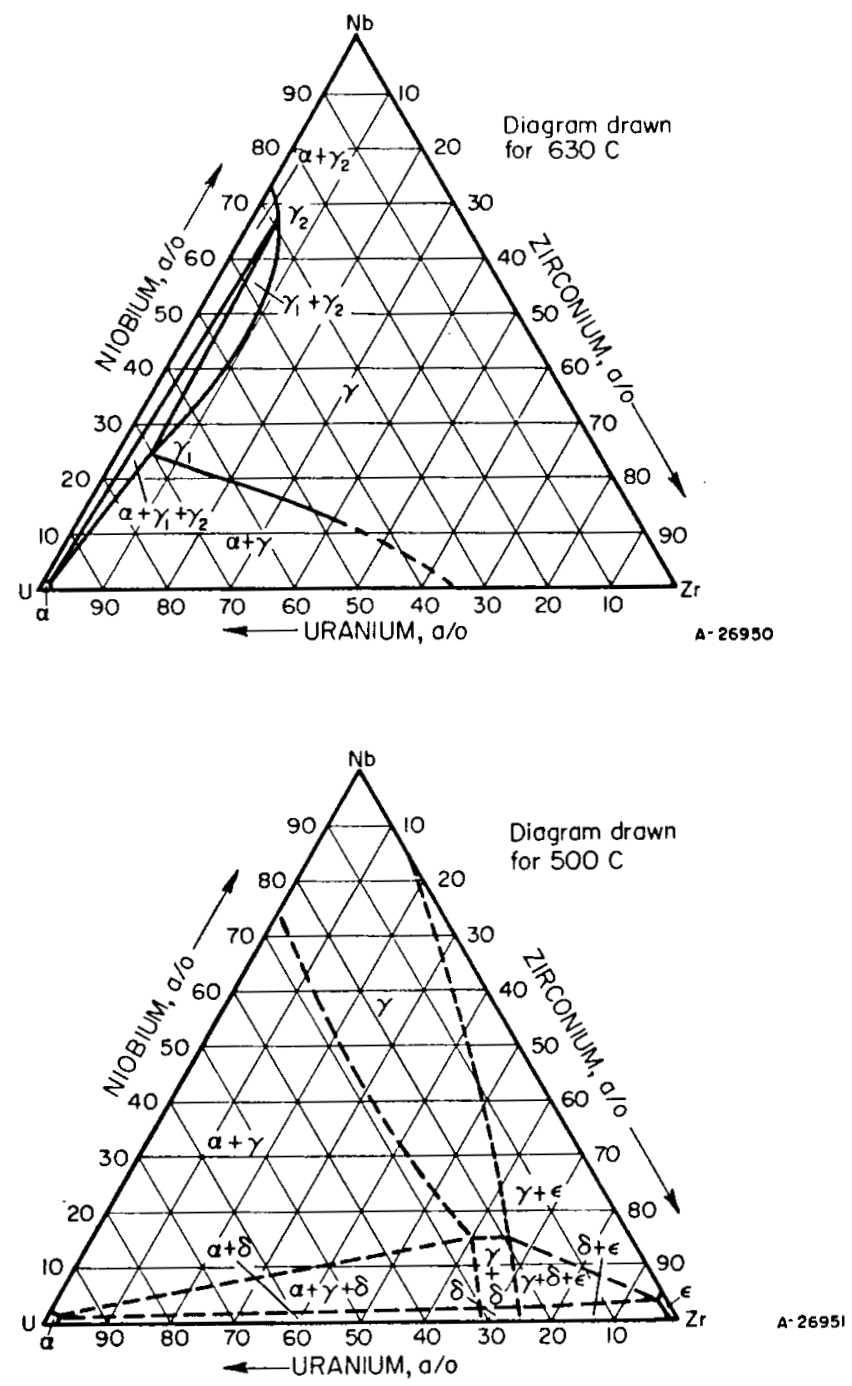

The Constitutional Diagram

The uranium-rich portion of the system has been investigated by Dwight and Mueller(1). Ternary sections showing the phase boundaries as they exist at 630 and $500 \mathrm{C}$ are shown in the accompanying figure.

At elevated temperatures, uranium, zirconium, and niobium exhibit complete solubility. The addition of about 2 a $/ 0$ niobium closes the gamma 1 -plus-gamma loop in the uraniumzirconium system, while the addition of 15 a/o zirconium is required to eliminate this loop in the uranium-niobium system. With the addition of 15 a $/ 0$ niobium, the delta phase in the uranium-zirconium system is eliminated and the gamma phase is stabilized to room temperature.

\section{Crystallography}

No new phases are reported.

\section{$\underline{\text { Reference }}$}

(1) Dwight, A. E., and Mueller, M. H., "Constitution of Uranium Niobium and Uranium-Niobium-Zirconium Systems", ANL-5581 (October, 1957). 


\section{URANIUM-OXYGEN-ZIRCONIUM}
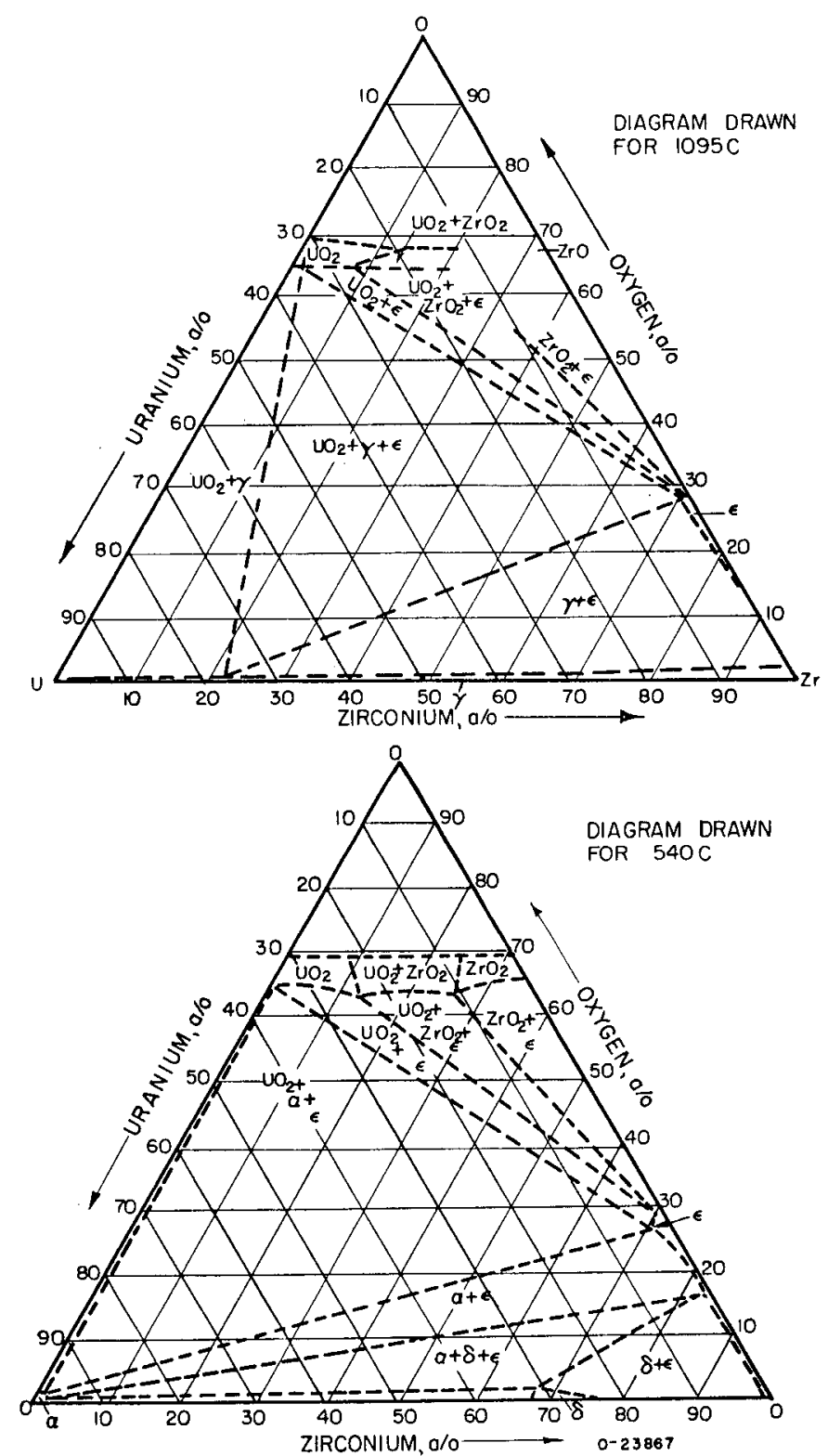

The Constitutional Diagram

The system was first investigated by Saller(1). Confirmation of the phase relationships in the system has been reported by Rough $(2)$ in the region of the intermediate delta phase of the uranium-zirconium system.

The delta phase is seen to be restricted in extent by oxygen additions. Solubility of oxygen in the uranium-zirconium delta phase is slightly.less than $500 \mathrm{ppm}$, solubilities in the ternary section drawn for $540 \mathrm{C}$ being exaggerated to permit illustration of the phase relationships.

The restriction of the delta phase is a consequence of the pronounced stabilizing effect of oxygen on the epsilon (alpha-zirconium) phase. (3) As a result of this stabilization, an equilibrium between the alpha-uranium and epsilon (alpha-zirconium) phases is set up which restricts the delta phase. 
The same phase relationships exist for the gamma-uranium phase above the delta-phase transformation temperature. With increasing temperature the limits of the gamma phase in the binary system broaden until complete solubility exists as shown in the diagram drawn for a temperature of $1095 \mathrm{C}$.

Solubility of oxygen in the gamma phase is limited.

\section{Crystallography}

No new phases have been reported.

\section{References}

(1) Saller, H. A., Rough, F. A., Bauer, A. A., and Fackelmann, J. M. ,."Phase Relationships of the Uranium-Zirconium-Oxygen System Involving Zirconium and Uranium Dioxide", BMI- 1023 (July 28, 1955).

(2) Rough, F. A., Austin, A. E., Bauer, A. A., and Doig, J. R., "The Stability and Existence Range of the Zirconium-Uranium Epsilon Phase", BMI- 1092 (May 28, 1956).

(3) Domagala, R. F., and McPherson, D. J., "Systems Zirconium-Oxygen", Trans. AIME, 200 (1954).

\section{URANIUM-THORIUM-ZIRCONIUM}

The effect of small additions of zirconium on the eutectic and liquid immiscibility gaps that occur in binary uranium-thorium alloys has been studied by thermal analysis and metallographic methods in arc-melted alloys. (1) No new phases were observed, the zirconium being dissolved in the thorium and uranium. With 13 a $/ 0$ zirconium the pseudo binary eutectic occurs at 7 a $/ 0$ thorium and $1168 \mathrm{C}$. No liquid immiscibility gap occurs in alloys containing 10 a $/ 0$ zirconium.

\section{Crystallography}

No new phases have been reported.

\section{Reference}

(1) Murray, J. R., United Kingdom, unpublished information (1957). 


\section{URANIUM-TITANIUM-ZIRCONIUM}
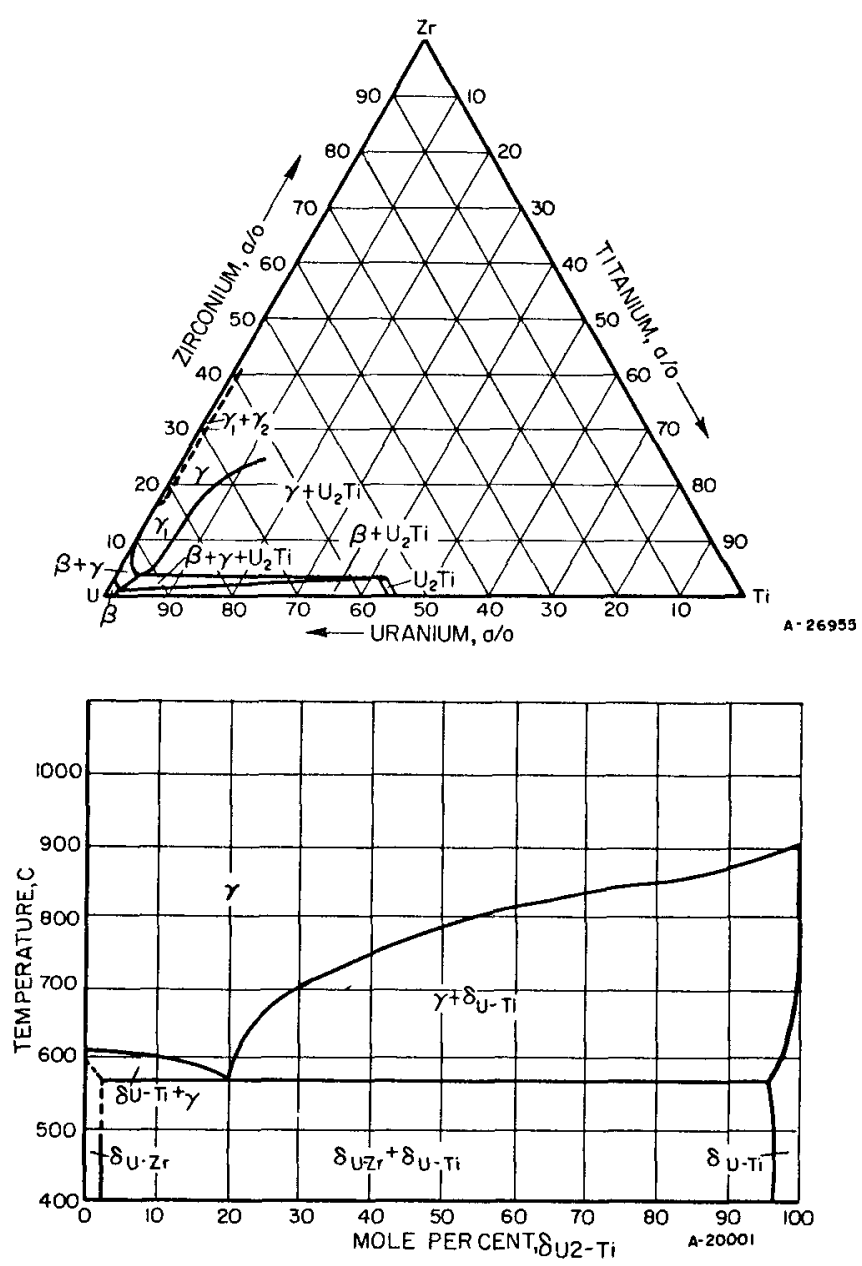

The Constitutional Diagram

An investigation of the region between the intermediate delta phases of the uraniumtitanium and uranium-zirconium systems has been reported(1), as has been a study of the highuranium portion of the system at temperatures of $700,750,800$, and $850 \mathrm{C}$. (2) The results of both investigations are consistent with each other. A tentative ternary cut based upon data obtained from alloys ranging in composition from uranium-35 a /0 titanium to uranium- 74 a $/ 0$ zirconium $(1)$ is shown as is a ternary section for $700 \mathrm{C}$. (2)

At elevated temperatures uranium, titanium, and zirconium exhibit complete solid solubility. The gamma phase is stabilized to a temperature below the binary uranium-zirconium eutectoid. (1)

Ternary solubility of zirconium and titanium in the respective delta phases is limited. (1) Solubility of zirconium in $\mathrm{U}_{2} \mathrm{Ti}$ decreases with inc'reasing temperature; a corresponding decrease in extent of the gamma-plus- $U_{2}$ Ti region accompanies this decreasing solubility. (2)

At $700 \mathrm{C}$ the addition of less than 1.5 a/o titanium to uranium-zirconium alloys is responsible for the disappearance of the gamma ${ }_{1}$-plus-gamma 2 field. (2)

\section{Crystallography}

No new phases have been reported.

\section{References}

(1) Saller, H. A., Rough, F. A., Bauer, A. A., and Doig, J. R., "Constitution of Delta-Phase Alloys of the System Uranium-Zirconium-Titanium", J. Metals, 9, 878-881 (July, 1957).

(2) Howlett, B. W. , Associated Electrical Industries Research Laboratory, United Kingdom, unpublished information (1957). 


\section{MELTING POINTS AND ALLOTROPIC MODIFICATIONS OF THORIUM}

The metal thorium is face-centered cubic at room temperature and body-centered cubic at high temperature.

The existence of a high-temperature thorium modification has been demonstrated by Chiotti(1), who employed high-temperature X-ray diffraction methods. Evidence for and confirmation of the allotropic change has been reported by a number of additional inve stigators $(2,3,4,5)$.

The temperature of the thorium transformation has been determined by Chiotti $(6)$ to be $1360 \pm 10 \mathrm{C}$ and the melting point $1755 \pm 10 \mathrm{C}$. These values were derived by studying throium of varying carbon content and extrapolating the curves of transformation and melting temperatures back to zero carbon. These temperatures have been used to standardize the construction of the thorium constitutional diagrams.

The lattice constants of alpha and beta thorium vary somewhat with grade and degree of contamination. The lattice constants tabulated are for production-grade thorium. The lattice constant of alpha thorium increases from $5.089 \mathrm{~A}$ at room temperature to $5.161 \mathrm{~A}$ at $1200 \mathrm{C}^{(1)}$.

\begin{tabular}{|c|c|c|c|c|c|c|c|}
\hline \multirow[b]{3}{*}{ Phase } & \multicolumn{3}{|c|}{ Unit Cell } & \multirow{2}{*}{\multicolumn{2}{|c|}{$\begin{array}{l}\text { Density, } \\
\text { g/ } \mathrm{cm}^{3}\end{array}$}} & \multirow{3}{*}{$\begin{array}{l}\text { Space } \\
\text { Group } \\
\end{array}$} & \multirow[b]{3}{*}{ Remarks } \\
\hline & \multirow[b]{2}{*}{ Type } & \multirow{2}{*}{$\begin{array}{c}\text { Dimensions, } \\
\mathrm{A} \\
\end{array}$} & \multirow{2}{*}{$\begin{array}{c}\text { Number } \\
\text { of } \\
\text { Molecules } \\
\end{array}$} & & & & \\
\hline & & & & X-Ray & Other & & \\
\hline Alpha & $F c c$ & $a=5.089$ & & & 11.6 & & $\begin{array}{l}\text { At room } \\
\text { temperature }\end{array}$ \\
\hline Beta & $\mathrm{Bcc}$ & $\mathrm{a}=4.12$ & & & & & At $1400 \mathrm{C}$ \\
\hline
\end{tabular}

References

(1) Chiotti, P., "High-Temperature Crystal Structure of Thorium", J. Electrochem. Soc., 101, 567-70 (1954).

(2) Murray, J. R., United Kingdom, unpublished information (June 25, 1952).

(3) Deem, H. W., unpublished information (1953).

(4) Boyle, E. J., and Adams, R. E., unpublished information (1953).

(5) Wilson, W. B., Austin, A. E., and Schwartz, C. M., "The Solid Solubility of Uranium in Thorium and the Allotropic Transformation of Thorium-Uranium Alloys", BMI-1111 (July 12, 1956).

(6) Chiotti, P., unpublished information (1955). 
THORIUM - BINARY SYSTEMS

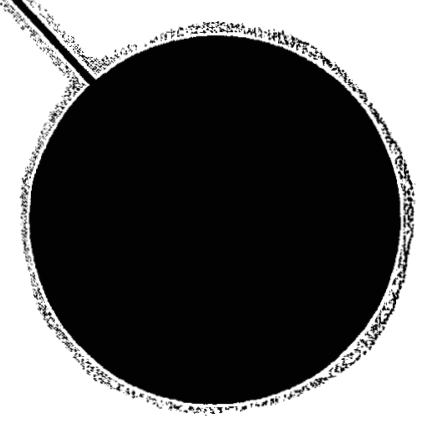




\section{THORIUM-ALUMINUM}

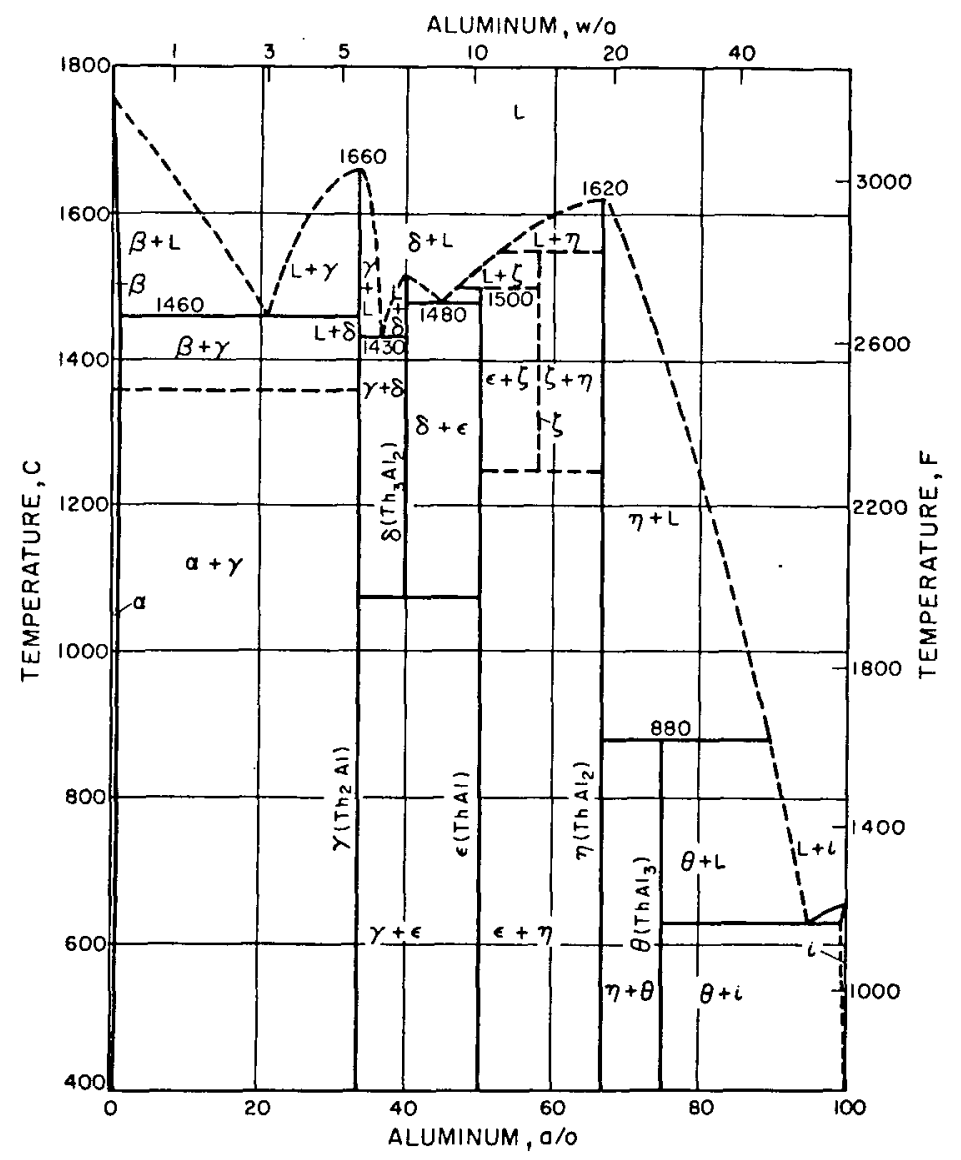

The Constitutional Diagram

The diagram shown is based on experiments by Murray (1), Braun and van Vucht $(2,3)$, and Leber(4). There are six compounds in the system: Th2 $\mathrm{Al}, \mathrm{Th}_{3} \mathrm{Al}_{2}, \mathrm{ThAl}, \mathrm{ThAl}_{2}$, $\mathrm{ThAl}_{3}$, and a sixth compound stable only at high temperatures, with a composition between ThAl and ThAl2. There are many points of similarity between this diagram and an earlier one proposed by Saller and Rough $(5)$ who obtained evidence for four intermetallic compounds.

Hansen $(6)$ surveyed early experiments on these alloys. The result of this survey and the work of Grube and Botzenhardt(7) are in general agreement with the diagram as shown.

The solid solubility in aluminum in carefully homogenized alloys appear $s$ to be a maximum of $0.7-0.8 \mathrm{w} / \mathrm{o}$ thorium. (5) This estimate is based on metallographic examination and thermal analyses of a series of alloys. Determinations of lattice constants indicate as much as $2.0 \mathrm{w} / \mathrm{o}$ thorium is soluble in aluminum. (7) The same report indicates that the solubility decreases with decreasing temperature. Another report indicates a solubility as low as $0.001 \mathrm{w} / 0$ thorium $(8)$ on the basis of measurements on microhardness. This procedure appears to be questionable, at least in this case.

The solid solubility of aluminum in thorium is quite limited, being approximately 0.8 a/o aluminum at $1200 \mathrm{C} .(1)$

\section{Crystallography}

The crystal structures of compounds in this system have been reported by Braun and van Vucht. $(2,3)$ Murray (9) has also reported the structures of $\mathrm{Th}_{2} \mathrm{Al}, \mathrm{Th}_{3} \mathrm{Al}_{2}, \mathrm{ThAl}_{2}$, and $\mathrm{ThAl}_{3}$, while Anderson and Goedkoop $(10)$ confirmed the structure of $\mathrm{ThAl} 2$ by neutron-

diffraction studies. The $\mathrm{ThAl}_{3}$ lattice parameters had been reported earlier by Brauer (11).

Some evidence for a high-temperature modification of the ThAl 2 phase has been reported by Saller and Rough $(5)$. 


\begin{tabular}{|c|c|c|c|c|c|c|c|}
\hline \multirow[b]{3}{*}{ Phase } & \multicolumn{3}{|c|}{ Unit Cell } & \multirow{2}{*}{\multicolumn{2}{|c|}{$\begin{array}{c}\text { Density, } \\
\mathrm{g} / \mathrm{cm}^{3} \\
\end{array}$}} & \multirow{3}{*}{$\begin{array}{l}\text { Space } \\
\text { Group }\end{array}$} & \multirow[b]{3}{*}{ Remarks } \\
\hline & & Dimensions, & $\begin{array}{c}\text { Number } \\
\text { of }\end{array}$ & & & & \\
\hline & Type & $\mathrm{A}$ & Molecules & X-Ray & Other & & \\
\hline $\begin{array}{l}\text { Gamma } \\
\qquad\left(\mathrm{Th}_{2} \mathrm{Al}\right)\end{array}$ & Tetragonal & $\begin{array}{l}a=7.614 \\
c=5.857\end{array}$ & 4 & 9.67 & 9.7 & $\mathrm{I} 4 / \mathrm{mcm}$ & $\begin{array}{l}\text { Isomorphous } \\
\text { with } \mathrm{CmAl}_{2}, \\
\mathrm{Th}_{2} \mathrm{Ag}, \mathrm{Th}_{2} \mathrm{Au}, \\
\mathrm{Th}_{2} \mathrm{Cu}, \mathrm{Th}_{2} \mathrm{Zn}\end{array}$ \\
\hline $\begin{array}{l}\text { Delta } \\
\qquad\left(\mathrm{Th}_{3} \mathrm{Al}_{2}\right.\end{array}$ & Tetragonal & $\begin{array}{l}a=8.125 \\
c=4.217\end{array}$ & 2 & 9.0 & 9.0 & $\mathrm{P} 4 / \mathrm{mbm}$ & $\begin{array}{l}\text { Isomorphous } \\
\text { with } \mathrm{U}_{3} \mathrm{Si}_{2}, \\
\mathrm{Th}_{3} \mathrm{Si}_{2}\end{array}$ \\
\hline $\begin{array}{l}\text { Epsilon } \\
\text { (ThAl) }\end{array}$ & Orthorhombic & $\begin{array}{l}a=11.45 \\
b=4.42 \\
c=4.19\end{array}$ & 4 & 8.11 & 8.10 & $\mathrm{C} 222$ & \\
\hline $\begin{array}{r}\text { Zeta } \\
(\mathrm{X})\end{array}$ & Tetragonal & $\begin{array}{l}a=9.89 \\
c=7.81\end{array}$ & & & & & \\
\hline $\begin{array}{l}\text { Eta } \\
\qquad\left(\mathrm{ThAl}_{2}\right)\end{array}$ & Hexagonal & $\begin{array}{l}a=4.388 \\
c=4.162\end{array}$ & 1 & 7. 0 & 7.0 & $\begin{array}{l}\mathrm{P} 6 / \\
\mathrm{mmm}\end{array}$ & $\begin{array}{l}\text { Isomorphous } \\
\text { with } \mathrm{AlB}_{2}, \\
\text { ThCu } \\
\beta-\mathrm{ThSi}_{2},\end{array}$ \\
\hline $\begin{array}{l}\text { Theta } \\
\left(\mathrm{ThAl}_{3}\right)\end{array}$ & Hexagonal & $\begin{array}{l}a=6.500 \\
c=4.626\end{array}$ & 2 & 6.14 & 6.14 & $\begin{array}{l}\mathrm{P}_{3} / \\
\mathrm{mmc}\end{array}$ & $\begin{array}{c}\text { Isomorphous } \\
\text { with } \mathrm{SnNi}_{3}\end{array}$ \\
\hline
\end{tabular}

\section{$\underline{\text { References }}$}

(1) Murray, J. R., United Kingdom, unpublished information (June, 1956).

(2) Braun, P. B., and van Vucht, J. H. N., "A1-Th Intermetallic Compounds I", Acta Cryst. 8, 117 (1955).

(3) Braun, P. B., and van Vucht, J. H. N., "Al-Th Intermetallic Compounds II", Acta Cryst. 8 , 246 (1955).

(4) Leber, A., "On the. System Al-Th", Z. anorg. u. allgem. Chem., 166, 16 (1927).

(5) Saller, H. A., and Rough, F. A., private communication (1952).

(6) Hansen, M., Der Aufbau der Zweistofflegierungen, Edwards Bros. Inc., Ann Arbor, Michigan, 156 (1943).

(7) Grube, G., and Botzenhardt, L., "Alloys of Thorium With Copper, Aluminum, and Sodium", z. Elektrochem., $\underline{48}, 422$ (1942).

(8) Buckle, H., "Solubility Determinations by Means of Micro-Hardness Tests", Metallforschung, 1,43 (1946).

(9) Murray, J. R., "The Crystal Structures of Some Thorium Compounds", J. Inst. Metals, 4, 91-96 (1955).

(10) Andersen, A. F., and Goedkoop, J. A., "Neutron Diffraction Study of $\mathrm{Al}_{2} \mathrm{Th}^{\text {", Acta }}$ Cryst., 8, 118 (1955).

(11) Brauer, G., "Crystal Structure of Intermetallic Compounds of Aluminum With Titanium, Zirconium, Thorium, Columbium, and Tantalum", Naturwisenschaften, 26, 710 (1938). 


\section{THORIUM-ANTIMONY}

A diagram of the thorium-antimony system has not been worked out but there is evidence

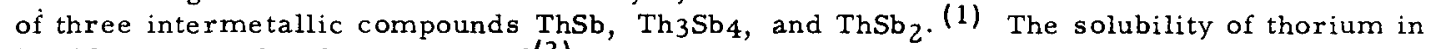
liquid antimony has been reported(2) as:

$\begin{array}{lcccccc}\text { Temperature, C } & 650 & 700 & 750 & 800 & 850 & 900 \\ \text { Solubility, w/o } & <0.05 & <0.05 & 0.1 & 0.3 & 0.5 & 1.0\end{array}$

Crystallography

\begin{tabular}{|c|c|c|c|c|c|c|c|}
\hline \multirow[b]{2}{*}{ Phase } & \multirow[b]{2}{*}{ Type } & Dimensions, & $\begin{array}{c}\text { Number } \\
\text { of }\end{array}$ & \multicolumn{2}{|c|}{$\begin{array}{c}\text { Density, } \\
\mathrm{g} / \mathrm{cm}^{3} \\
\end{array}$} & \multirow{2}{*}{$\begin{array}{l}\text { Space } \\
\text { Group }\end{array}$} & \multirow[b]{2}{*}{ Remarks } \\
\hline & & $\mathrm{A}$ & Molecules & X-Ray & Other & & \\
\hline ThSb & $\mathrm{Fcc}$ & $a=6.318$ & 4 & 9.32 & & & $\begin{array}{l}\text { NaCl-type structure, } \\
\text { isomorphous with } \\
\text { ThAs, ThC, ThN, US }\end{array}$ \\
\hline $\mathrm{Th}_{3} \mathrm{Sb}_{4}$ & $\mathrm{Bcc}$ & $a=9.374$ & 4 & 9.55 & & $I \overline{4} 3 d$ & $\begin{array}{l}\text { Is omor phous with } \\
\mathrm{Th}_{3} \mathrm{P}_{4}, \mathrm{Th}_{3} \mathrm{As}_{4} \\
\mathrm{Th}_{3} \mathrm{Bi}_{4}, \mathrm{U}_{3} \mathrm{Sb}_{4}\end{array}$ \\
\hline $\mathrm{ThSb}_{2}$ & $\begin{array}{l}\text { Tetrago- } \\
\text { nal }\end{array}$ & $\begin{array}{l}\mathrm{a}=4.353 \\
\mathrm{c}=9.172\end{array}$ & 2 & 9.09 & & $\mathrm{P} 4 / \mathrm{nmn}$ & $\begin{array}{l}\text { Isomorphous with } \\
\mathrm{ThAs}_{2}, \mathrm{ThBi}_{2}, \mathrm{USb}_{2} \text {, } \\
\mathrm{Cu}_{2} \mathrm{Sb}\end{array}$ \\
\hline
\end{tabular}

References

(1) Ferro, R., "Crystal Structures of the Thorium Antimonides", Acta Cryst., 9 (10), 817 (1956).

(2) Hayes, E. E., and Gordon, P., J. Met. and Cer., TID-65, 130-41 (July, 1948). Classified.

\section{THORIUM-ARSENIC}

A diagram of the thorium-arsenic system has not been worked out but there is evidence of three intermetallic compounds, ThAs, $\mathrm{Th}_{3} \mathrm{As}_{4}$, and $\mathrm{ThAs} 2$.

\section{Crystallography}

The data below are from Ferro(1).

\begin{tabular}{|c|c|c|c|c|c|c|}
\hline \multirow[b]{3}{*}{ Phase } & \multicolumn{3}{|c|}{ Unit Cell } & \multirow{2}{*}{$\begin{array}{l}\text { Density, } \\
\mathrm{g} / \mathrm{cm}^{3}\end{array}$} & \multirow{3}{*}{$\begin{array}{l}\text { Space } \\
\text { Group }\end{array}$} & \multirow[b]{3}{*}{ Remarks } \\
\hline & \multirow[b]{2}{*}{ Type } & \multirow{2}{*}{$\begin{array}{c}\text { Dimensions, } \\
\mathrm{A} \\
\end{array}$} & \multirow{2}{*}{$\begin{array}{l}\text { Number of } \\
\text { Molecules }\end{array}$} & & & \\
\hline & & & & X-Ray Other & & \\
\hline ThAs & Fcc & $a=5.972$ & 4 & & & $\begin{array}{l}\text { NaCl-type structure, } \\
\text { isomorphous with ThSb, } \\
\text { ThC, ThN, UAs }\end{array}$ \\
\hline $\mathrm{Th}_{3} \mathrm{As}_{4}$ & $\mathrm{Bcc}$ & $a=8.843$ & 4 & & $I 43 d$ & $\begin{array}{l}\text { Isomorphous with } \mathrm{Th}_{3} \mathrm{P}_{4} \\
\mathrm{Th}_{3} \mathrm{Sb}_{4}, \mathrm{U}_{3} \mathrm{As}_{4} \\
\mathrm{Th}_{3} \mathrm{Bi}_{4}\end{array}$ \\
\hline ThAs 2 & $\begin{array}{l}\text { Tetrago- } \\
\text { nal }\end{array}$ & $\begin{array}{l}a=4.086 \\
c=8.575\end{array}$ & 2 & & $\mathrm{P} 4 / \mathrm{nmn}$ & $\begin{array}{l}\text { Isomorphous with } \mathrm{ThSb}_{2} \text {, } \\
\mathrm{UAs}_{2}, \mathrm{ThBi}_{2}, \mathrm{Cu}_{2} \mathrm{Sb}\end{array}$ \\
\hline
\end{tabular}




\section{Reference 8}

(1) Ferro, R., "The Crystal Structures of the Thorium Arsenides", Acta Cryst., 8 , 360 (1955).

\section{THORIUM-BERYLLIUM}

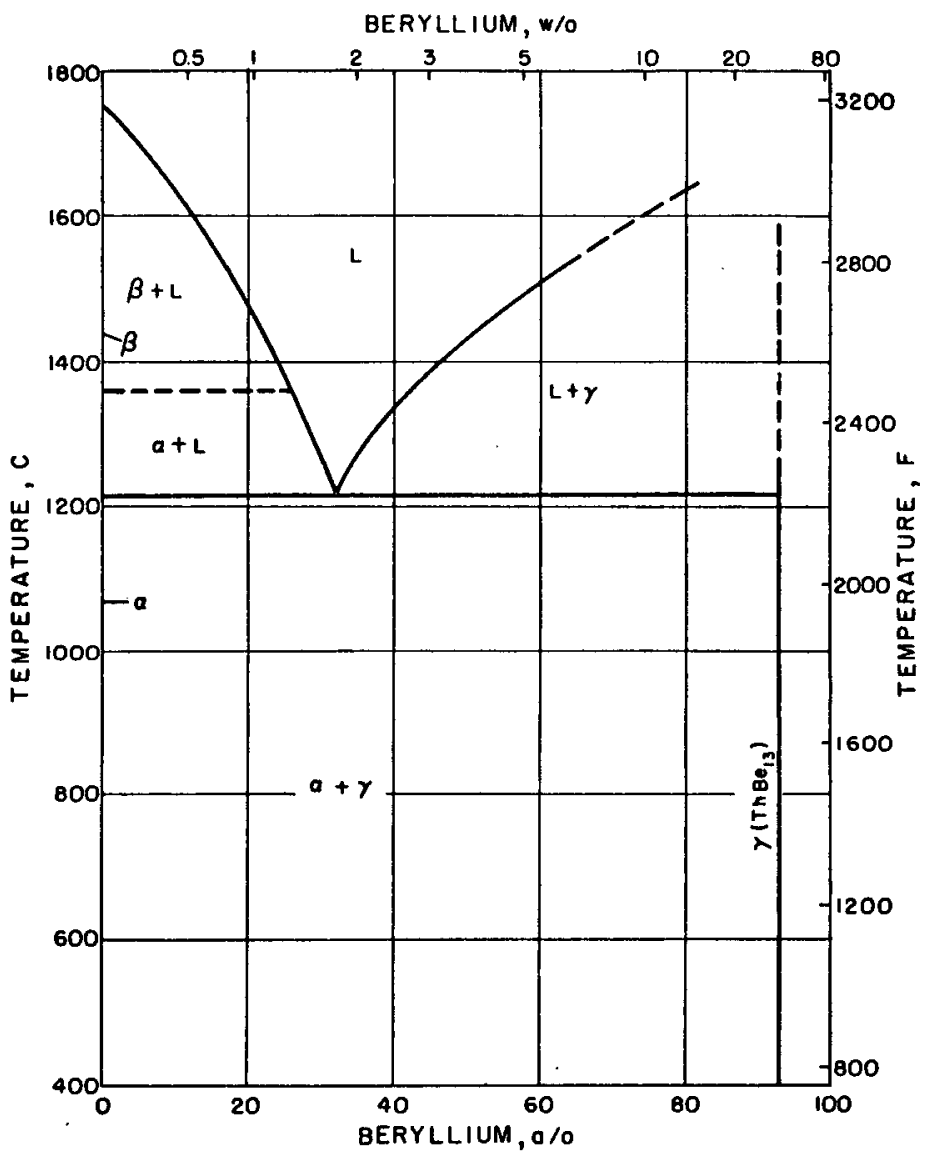

The Constitutional Diagram

There is only one compound, $\mathrm{ThBe}_{13}$, in this system. The portion of the system which is shown has been reported both by Spedding(1) and by Foote( 2 .

The eutectic occurs at about $1.75 \mathrm{w} / \mathrm{o}$ beryllium and $1215 \mathrm{C}$.

\section{Crystallography}

The compound $\mathrm{ThBe}_{13}$ has been studied by Baenziger( 3 ) and also by Koehler(4). The data in the tabulation below are from Baenziger. Koehler confirms these data, on the basis of both $\mathrm{X}$-ray and neutron-diffraction experiments.

\begin{tabular}{|c|c|c|c|c|c|}
\hline \multirow[b]{2}{*}{ Phase } & \multicolumn{3}{|c|}{ Unit Cell } & \multirow[b]{2}{*}{$\begin{array}{l}\text { Space } \\
\text { Group }\end{array}$} & \multirow[b]{2}{*}{ Remarks } \\
\hline & Type & $\begin{array}{c}\text { Dimensions, } \\
\text { A }\end{array}$ & $\begin{array}{l}\text { Number } \\
\text { of } \\
\text { Molecules }\end{array}$ & & \\
\hline $\begin{array}{l}\text { Gamma } \\
\qquad\left(\mathrm{ThBe}_{13}\right)\end{array}$ & $\mathrm{Fcc}$ & $a=10.395$ & 8 & $\mathrm{Fm} 3 \mathrm{C}$ & $\begin{array}{l}\text { Isomorphous with } \mathrm{NaZn}_{13} \text {, } \\
\mathrm{ZrBe}_{13}, \mathrm{CeBe} 13 \text {, and } \\
\mathrm{UBe}_{13}\end{array}$ \\
\hline
\end{tabular}


(1) Spedding, F. H., unpublished information (November, 1944).

(2) Foote, Frank, Metallurgy Division Progress Report, CT-2794 (April, 1945).

(3) Baenziger, N. G., and Rundle, R. E., "The MBe 13 Compounds" (AECD-2506), Acta Cryst. 2, 258 (1945).

(4) Koehler, W. C., Singer, J., and Coffinberry, A. S., "X-Ray and Neutron Diffraction Studies of the $\mathrm{MBe}_{13}$ Intermetallic Compounds", Acta Cryst., 5, 394 (1952).

\section{THORIUM-BISMUTH}

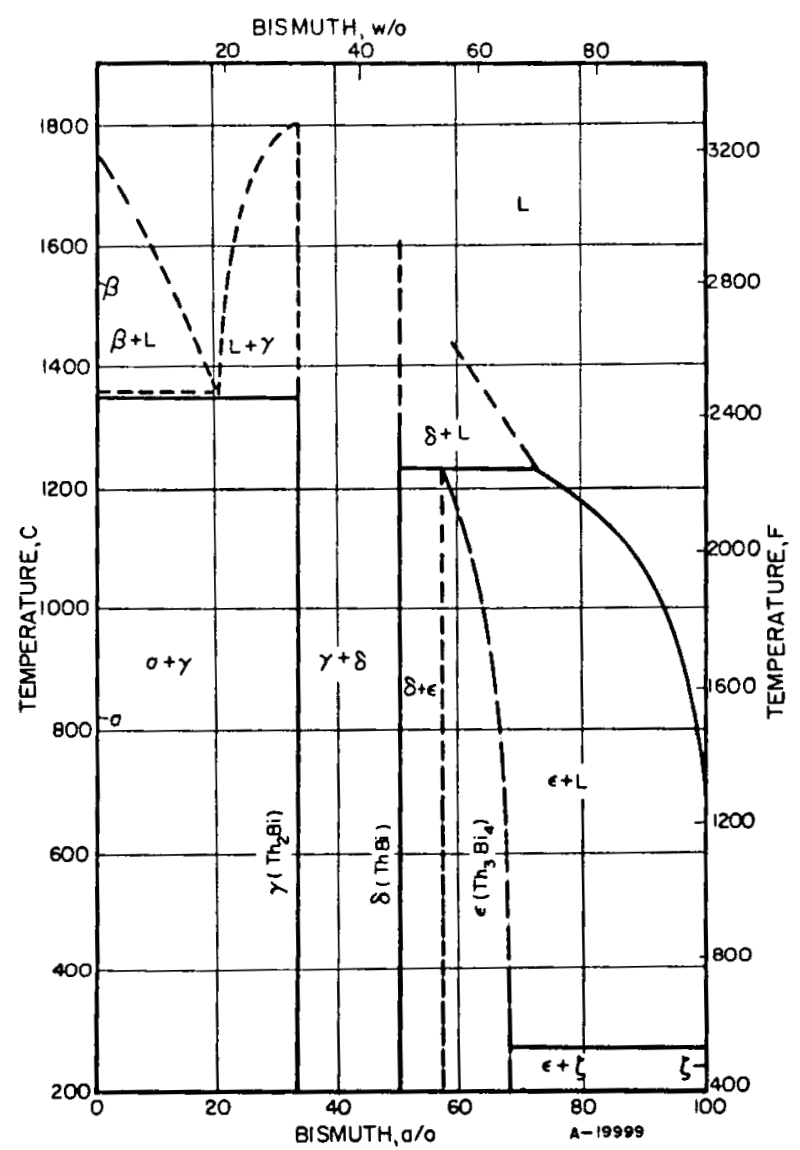

\section{The Constitutional Diagram}

The diagram shown is from Bryne $\mathbf{r}^{(1)}$; it is revised to include the compound $\mathrm{Th}_{3} \mathrm{Bi}_{4}$ as determined by Ferro(2). Bryner had indicated this compound as having a composition corresponding to $\mathrm{Th}_{3} \mathrm{Bi}_{5}$. Earlier, Johnson(3) had reported the same compound as ThBi3. Ferro has also identified $\mathrm{ThBi}_{2}$ and reports that two phases close to $\mathrm{ThBi}$ in composition may exist. (2)

Alloys containing 20 to $100 \mathrm{w} / \mathrm{o}$ bismuth have also been investigated by Clinton(4). His results, obtained by thermal analysis, are in substantial agreement with the diagram shown except that the liquidus is reported to rise more steeply, the liquidus of a 3 a/o thorium alloy being $1250 \mathrm{C}$. 
A summary (5) of the solubility of thorium in bismuth as determined by several investigators $(1,6,7)$ has been issued; the results show good agreement. Values as given by Hayes and Gordon $(6)$ are:

$\begin{array}{llllllllll}\text { Temperature, C } & 500 & 550 & 600 & 650 & 700 & 750 & 800 & 850 & 900 . \\ \text { Solubility, w/0 } & 0.1 & 0.2 & 0.3 & 0.5 & 0.7 & 1.1 & 1.5 & 2.3 & 3.2\end{array}$

Values for solubility obtained by Greenwood( 8 ) show some scatter but tend to be slightly lower than those reported by other workers. He found that at low temperatures the solubility curve follows the relation

$$
\log _{10}\left(\text { thorium, w/o) }=3.02-\frac{3220}{\mathrm{~T}}\right.
$$

The following values were obtained:

$\begin{array}{lllllllll}\text { Temperature, C } & 415 & 509 & 596 & 700 & 801 & 923 & 1042 & 1100 \\ \text { Solubility, w/o } & 0.04 & 0.08 & 0.39 & 0.43 & 1.25 & 2.2 & 4.2 & 5.6\end{array}$

\section{Crystallography}

The data below are from Ferro(2).

\begin{tabular}{|c|c|c|c|c|c|c|c|}
\hline \multirow[b]{3}{*}{ Phase } & \multicolumn{3}{|c|}{ Unit Cell } & \multirow{2}{*}{\multicolumn{2}{|c|}{$\begin{array}{c}\text { Density, } \\
\mathrm{g} / \mathrm{cm}^{3} \\
\end{array}$}} & \multirow{3}{*}{$\begin{array}{l}\text { Space } \\
\text { Group }\end{array}$} & \multirow[b]{3}{*}{ Remarks } \\
\hline & & Dimensions, & $\begin{array}{c}\text { Number } \\
\text { of }\end{array}$ & & & & \\
\hline & Type & $\mathrm{A}$ & Molecules & $\underline{X-R a y}$ & Other & & \\
\hline $\mathrm{Th}_{3} \mathrm{Bi}_{4}$ & $\mathrm{Bcc}$ & $a=9.559$ & 4 & 11.65 & & $I \overline{4} 3 d$ & $\begin{array}{l}\text { Isostructural with } \\
\mathrm{Th}_{3} \mathrm{P}_{4}, \mathrm{Th}_{3} \mathrm{As}_{4} \\
\mathrm{Th}_{3} \mathrm{Sb}_{4} \text {, and } U_{3} \mathrm{As}_{4}\end{array}$ \\
\hline $\mathrm{ThBi}_{2}$ & $\begin{array}{l}\text { Tetrago- } \\
\text { nal }\end{array}$ & $\begin{array}{l}a=4.492 \\
c=9.298\end{array}$ & 2 & 11.5 & & $\mathrm{P} 4 / \mathrm{nmm}$ & $\begin{array}{l}\text { Isostructural with } \\
\text { ThAs } 2, \mathrm{ThSb}_{2}, \mathrm{UAs}_{2} \text {, } \\
\text { and } \mathrm{Cu}_{2} \mathrm{Sb}\end{array}$ \\
\hline
\end{tabular}

\section{References}

(1) Bryner, J. S., and Teitel, R. J., private communication (1956).

(2) Ferro, R., Acta Cryst., 10, 476 (1957).

(3) Johnson, H. B., unpublished information (July, 1950).

(4) Clinton, D. M., United Kingdom, unpublished information (1955).

(5) Sibert, M. E., Steinberg, M. A., and Teitel, R. J., J. Electrochem Soc., 104, 374 (1957).

(6) Hayes, E. E., and Gordon, P., J. Met. and Cer., TID-65, BO-41 (July, 1948). Classified.

(7) Bareis, D. W., unpublished information (1957).

(8) Greenwood, A. W., AERE M/R 2234 (1957). 


\section{THORIUM-BORON}

Two borides, $\mathrm{ThB}_{4}$ and $\mathrm{ThB}_{6}$, have been observed and identified.

There is a eutectic between beta thorium and $\mathrm{ThB}_{4}$ at about $1550 \mathrm{C}$. The melting point of $\mathrm{ThB}_{4}$ is well above $2500 \mathrm{C}$. (I) The melting point of $\mathrm{ThB}_{6}$ has been reported as $2195 \mathrm{C}(2)$, but Brewer reports that $\mathrm{ThB}_{6}$ is too unstable for refractory use. (1)

Boron has been reported to be soluble in thorium to some extent( 3 ), but the amount has not been specified.

The lattice constant for $\mathrm{ThB}_{4}$ did not vary in alloys containing 25 to 85 a/o boron; hence, it appears that $\mathrm{ThB}_{4}$ has a very narrow solubility range. (1)

Existence of an additional boride at about 50 a/o boron has been reported. (3) This report probably should be discounted, since Brewer(1) has shown that thorium metal is present up to the composition of $\mathrm{ThB}_{4}$. A third phase in this region, identified as a solid solution of $\mathrm{ThO}_{2}$ and $\mathrm{ThB}_{4}(1)$, may account for reports of additional borides.

\section{Crystallography}

The tabulated data for $\mathrm{ThB}_{4}$ are those of $\mathrm{Zalkin}$ and Templeton(4), while the data for $\mathrm{ThB}_{6}$ are from the work of Kiessling(3).

The hexaboride, $\mathrm{ThB}_{6}$, was reported as early as $1932 .(5,6)$ More recent data are reported by Lafferty $(2)$ and by Bertaut and Blum (7). Lafferty gives the lattice constant for $\mathrm{ThB}_{6}$ as $\mathrm{a}=4.15 \mathrm{~A}$. Bertaut ${ }^{(7)}$ reports the same constant as a $=4.1132 \mathrm{~A}$, and indicates that the alkali metals can replace thorium in the lattice, giving solid solutions described by $T h_{\mathrm{X}^{N a}}(1-\mathrm{X})^{\mathrm{B}_{6}}$. Parameters are reported for the se solutions for $1-\mathrm{X}=0.44$ to 0.77 .

\begin{tabular}{|c|c|c|c|c|c|c|}
\hline \multirow[b]{3}{*}{ Phase } & \multicolumn{3}{|c|}{ Unit Cell } & \multirow[b]{2}{*}{ Density, $\mathrm{g} / \mathrm{cm}^{3}$} & \multirow{3}{*}{$\begin{array}{l}\text { Space } \\
\text { Group }\end{array}$} & \multirow[b]{3}{*}{ Remarks } \\
\hline & & Dimensions, & & & & \\
\hline & Type & A & Molecules & X-Ray Other & & \\
\hline $\operatorname{ThB}_{4}$ & Tetragonal & $\begin{array}{l}a=7.256 \pm 0.004 \\
c=4.113 \pm 0.002\end{array}$ & & 8.45 & $\begin{array}{l}\mathrm{P} 4 / \\
\mathrm{mbm}\end{array}$ & $\begin{array}{l}\text { Isomorphous with } \\
\mathrm{CeB}_{4} \text { and } \mathrm{ThB}_{4}\end{array}$ \\
\hline $\operatorname{ThB}_{6}$ & Cubic & $a=4.16$ & & & & $\begin{array}{l}\text { Isomorphous with } \\
\text { hexaborides of } \\
\mathrm{Ba}, \mathrm{Sr}, \mathrm{Ca}, \mathrm{Yb}, \\
\mathrm{La}, \mathrm{Ce}, \mathrm{Nd}, \mathrm{Pr}, \\
\mathrm{Gd}, \mathrm{Y}, \text { and } \mathrm{Er}\end{array}$ \\
\hline
\end{tabular}

\section{References}

(1) Brewer, L., Sawyer, D. L., Templeton, D. H., and Dauben, C. H., "The Borides of Uranium and Thorium", AECD-2823 (February 14, 1950).

(2) Lafferty, T. M., "Boride Cathodes", J. Appl. Phy. 22, 299-309 (1951).

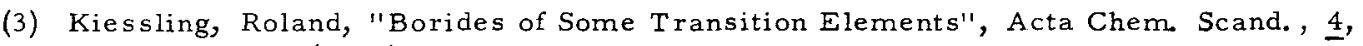
163 and 209-27 (1950).

(4) Zalkin, Allan, and Templeton, D. H., "The Crystal Structure of $\mathrm{CeB}_{4}$, ThB 4 , and $\mathrm{UB}_{4}{ }^{\prime \prime}$, J. Chem. Phys., 18, 391 (1950); reprinted in Acta Cryst., 6, 269-72 (March, 1953).

(5) Allard, G. , Bull. soc. chim. France, 51, 1213-5 (1932).

(6) Stachelberg, M. V., and Newmann, F., Z. physik. Chem., (B) 19, 314-20 (1932).

(7) Bertaut, F., Blum, P., "Hexaborides and Alkaline Substitutions", Compt. rend., 234, 2631-3 (1952). 


\section{THORIUM-CARBON}

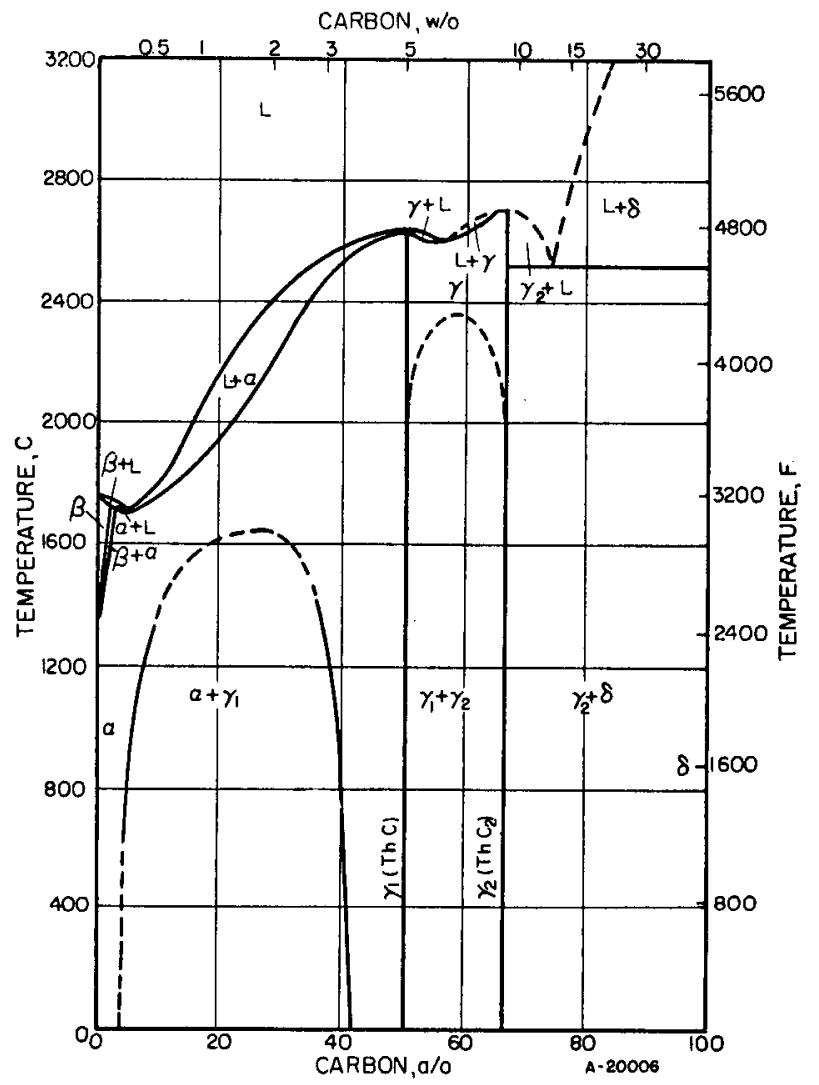

The Constitutional Diagram

The diagram shown is from Chiotti(1); it represents a tentative revision of his earlier work $(2,3)$. The pronounced effect of carbon on the thorium transformation temperature and melting point is well established. In fact, the values of 1360 and $1755 \pm 10 \mathrm{C}$, respectively, were obtained by examining thorium of varying carbon content and extrapolating plots of the resultant data to zero carbon.

Reported values $(1,4,5,)_{\text {of }}$ carbon solubility in alpha thorium vary with the experimental techniques employed in their determination and range from about 0.2 to $0.35 \mathrm{w} / \mathrm{o}$ carbon at room temperature. The solubility curve shown represents a workable interpretation until these discrepancies are resolved.

\section{Crystallography}

The monocarbide, ThC, has the NaCl-type structure. The data in the table are from Chiotti $(2,3)$, who found that the lattice constant varied from $5.29 \mathrm{~A}$ at $3.9 \mathrm{w} / 0$ carbon to 5. $34 \mathrm{~A}$ at $4.92 \mathrm{w} / 0$ carbon.

The dicarbide, $\mathrm{ThC}_{2}$, was formerly believed to have a distorted-tetragonal structure (2). Later studies by Hunt and Rundle $(6)$, who used both X-ray and neutron-diffraction methods, have shown that it is c-centered monoclinic, as described in the tabulation. The positions of the thorium atom as determined by X-ray are the same in either space group, while satisfactory carbon positions have been found in $\mathrm{C} 2 / \mathrm{c}$ by neutron diffraction. Considerable covalent character is indicated for the Th-C bonds. (6) 


\begin{tabular}{|c|c|c|c|c|c|c|c|}
\hline \multirow[b]{2}{*}{ Phase } & & Dimensions, & $\begin{array}{c}\text { Number } \\
\text { of }\end{array}$ & \multicolumn{2}{|c|}{$\begin{array}{c}\text { Density, } \\
\mathrm{g} / \mathrm{cm}^{3} \\
\end{array}$} & \multirow{2}{*}{$\begin{array}{l}\text { Space } \\
\text { Group } \\
\end{array}$} & \multirow[b]{2}{*}{ Remarks } \\
\hline & Type & $\mathrm{A}$ & Molecules & $\mathrm{X}$-Ray & Other & & \\
\hline $\begin{array}{r}\text { Gamma } \\
(\mathrm{ThC})\end{array}$ & $\mathrm{Fcc}$ & $a=5.34$ & 4 & & & & $\begin{array}{l}\text { NaCl-type struc- } \\
\text { ture, isomorphous } \\
\text { with ThN, UC, } \\
\text { UN, and UO. }\end{array}$ \\
\hline $\begin{array}{r}\text { Gamma } \\
\left(\mathrm{ThC}_{2}\right)\end{array}$ & $\begin{array}{l}\mathrm{c}-\text { Centered } \\
\text { monoclinic }\end{array}$ & $\begin{array}{l}a=6.53 \\
b=4.24 \\
c=6.56 \\
\beta=104^{\circ}\end{array}$ & 4 & & & $\begin{array}{l}\mathrm{C} 2 / \mathrm{c} \\
\text { or } \\
\mathrm{Cc}\end{array}$ & \\
\hline
\end{tabular}

\section{References}

(1) Chiotti, P., private communication (September, 1956).

(2) Chiotti, P., "Thorium-Carbon System", AECD-3072 (June 5, 1950).

(3) Wilhelm H, A., and Chiotti, P., "Thorium-Carbon System", Trans. Am. Soc. Metals, 42, $1295-1310$ (1950).

(4) Peterson, D. , and Mickelson, R. , "Solubility of Carbon in Thorium", ISC-463 (February, 1954).

(5) Smith, M. D., United Kingdom, unpublished information (1954).

(6) Hunt, E. B., and Rundle, R. E., "The Structure of Thorium Carbide by X-ray and Neutron Diffraction" (AECD-3021), J. Am. Chem. Soc., 73, 4777-81 (1951). 


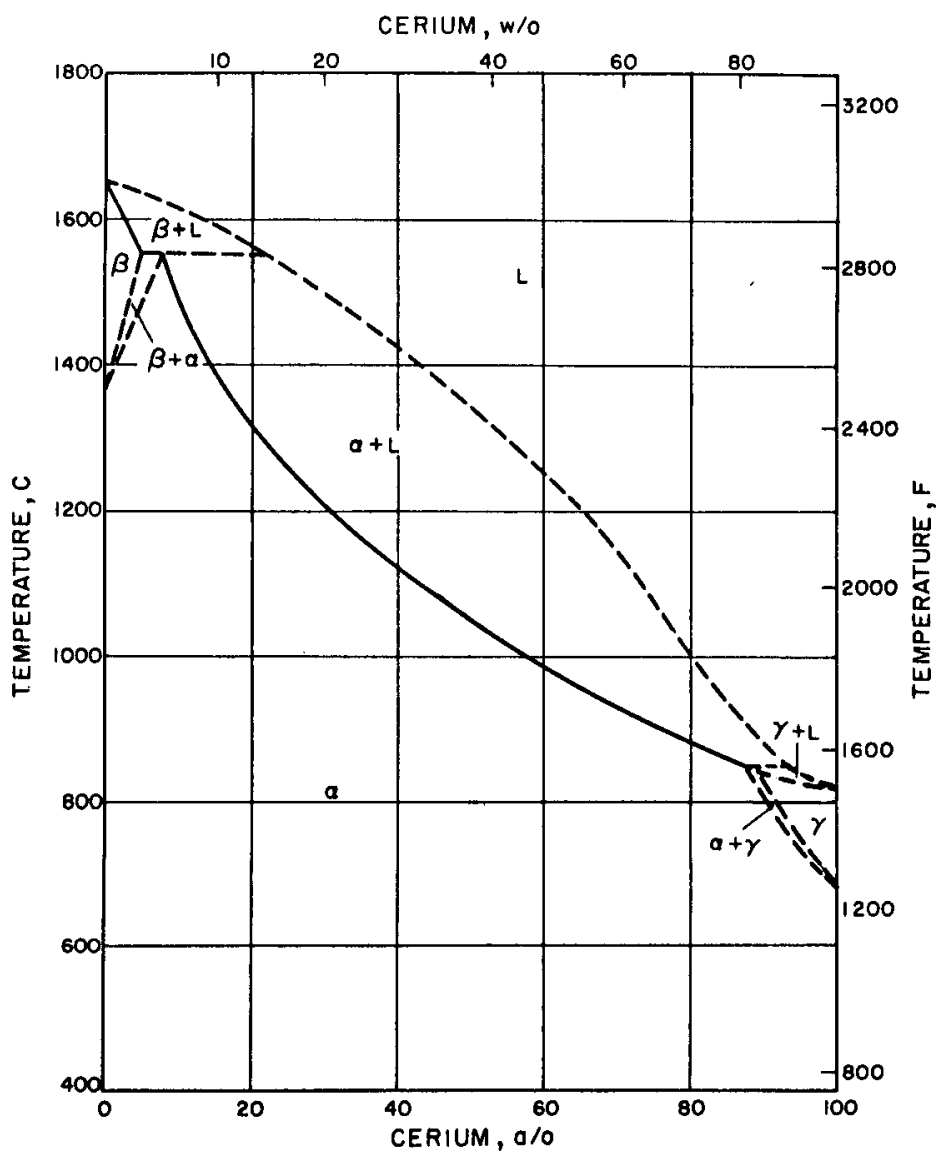

The Constitutional Diagram

The diagram which is shown has been reported by Weiner(1). All the alloys were prepared by arc melting. Lattice parameters of powder $\mathrm{s}$ which had been annealed at $550 \mathrm{C}$ showed a large negative deviation from Vegard's Law $(1,2)$.

Peterson(3) also investigated a series of thorium-cerium alloys and found that cerium and alpha thorium are completely soluble. He prepared the alloys by co-reduction at temperatures of 1000 to $1400 \mathrm{C}$. Earlier experiments by Foote(4) also indicated complete solubility in both the liquid and solid states in this system.

\section{Crystallography}

No compounds occur in this system.

\section{References}

(1) Weiner, R. T., United Kingdom, unpublished information (1956).

(2) Van Vucht, J. H., "Some Data About the System Cerium-Thorium", Philips Res. Rept., $12,351-54$ (1957).

(3) Peterson, D., and Mickelson, R., unpublished information (March 31, 1952).

(4) Foote, F., Division of Metallurgy Report, CT-2794 (April, 1945). 


\section{THORIUM-CHROMIUM}

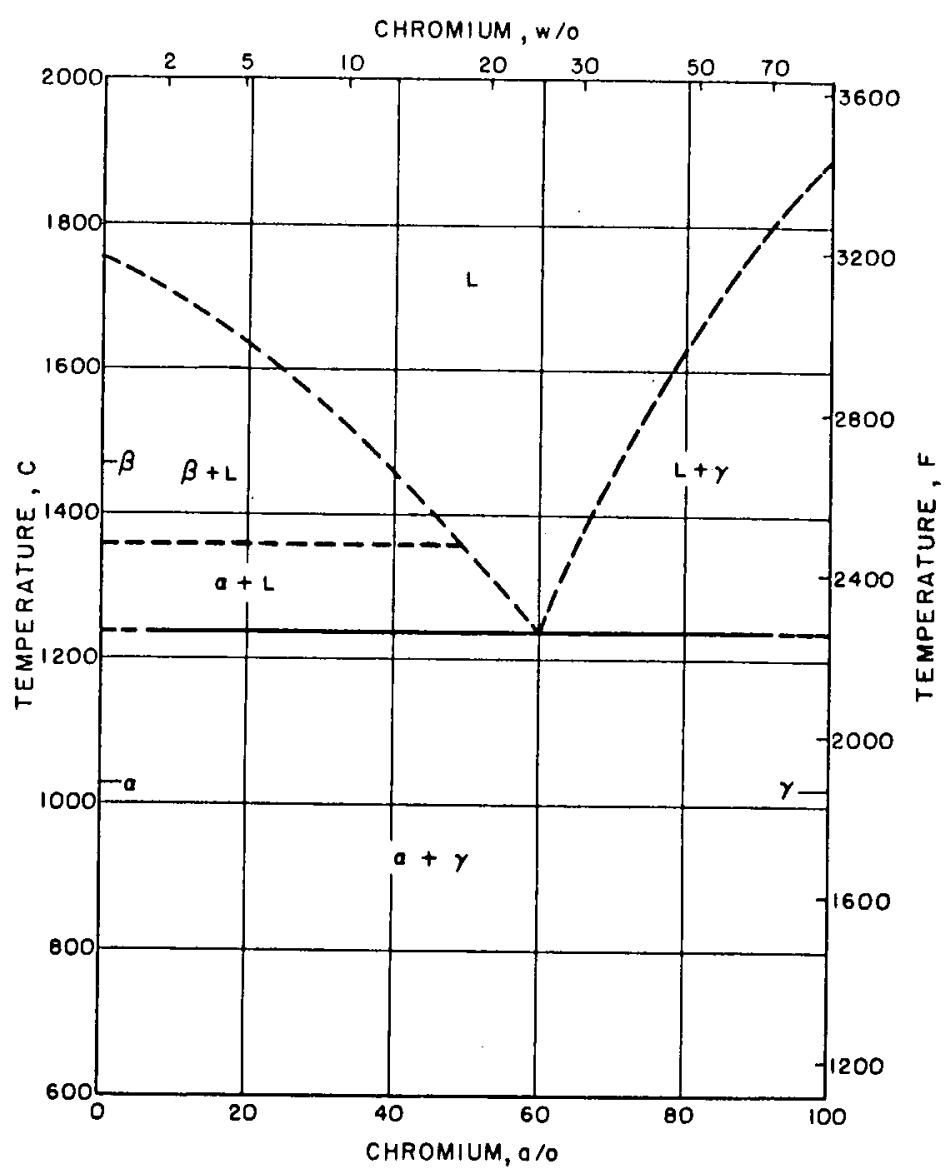

The Constitutional Diagram

The diagram which is shown has been reported by Wilhelm(1). The eutectic occurs at about 25 a/o chromium and $1235 \mathrm{C}$. The absence of compounds in the system was confirmed by $\mathrm{X}$-ray diffraction studies.

The solubility of thorium in chromium, and of chromium in thorium, is quite limited.

\section{Crystallography}

No compounds occur in this system.

\section{Reference}

(1) Wilhelm, H. A., Newton, A. S., Daane, A. H., and Neher, C., "Thorium Metallurgy", CT-3714 (February, 1946).

\section{THORIUM-COBALT}

A diagram of the thorium-cobalt system has not been worked out, but there is evidence of five intermetallic compounds, $\mathrm{Th}_{7} \mathrm{Co}_{3}, \mathrm{ThCo}, \mathrm{ThCo}_{2}, \mathrm{ThCo}_{5}$, and $\mathrm{Th}_{2} \mathrm{Co}_{17}$. 


\section{Crystallography}

The data below are from Florio, Baenziger, and Rundle(1).

Florio, Baenziger, and Rundle(1) report that $\mathrm{Th}_{2} \mathrm{Co}_{17}, \mathrm{Th}_{2} \mathrm{Fe}_{17}, \mathrm{Th}_{2} \mathrm{Ni}_{17}$, and $\mathrm{ThMn}_{12}$ are all related, even though different crystal classes are represented. The structures appear to be based on the $\mathrm{MgZn}_{5}$ lattice in which thorium replaces magnesium and the transition element replaces zinc. It is reported that the superlattices of hexagonal $\mathrm{Th} 2 \mathrm{Ni} 17$, monoclinic $\mathrm{Th}_{2} \mathrm{Fe}_{17}$ and $\mathrm{Th}_{2} \mathrm{Co}_{17}$, and body-centered tetragonal $\mathrm{ThMn} 12$ can be derived by systematic replacement of particular thorium atoms in the $\mathrm{MgZn}_{5}$ lattice with pairs of transition-element atoms.

\begin{tabular}{|c|c|c|c|c|c|c|}
\hline \multirow[b]{3}{*}{ Phase } & \multicolumn{3}{|c|}{ Unit Cells } & \multirow[b]{2}{*}{$\begin{array}{l}\text { Density, } \\
\mathrm{g} / \mathrm{cm}^{3}\end{array}$} & \multirow{3}{*}{$\begin{array}{l}\text { Space } \\
\text { Group }\end{array}$} & \multirow[b]{3}{*}{ Remarks } \\
\hline & & Dimensions, & $\begin{array}{c}\text { Number } \\
\text { of }\end{array}$ & & & \\
\hline & Type & $\begin{array}{c}\mathrm{A} \\
\end{array}$ & Molecules & X-Ray Other & & \\
\hline $\mathrm{Th}_{7} \mathrm{Co}_{3}$ & Hexagonal & $\begin{array}{l}a=9.83 \\
c=6.17\end{array}$ & 2 & & $\mathrm{C} 6 \mathrm{mc}$ & $\begin{array}{l}\text { Isomorphous with } \\
\mathrm{Th}_{7} \mathrm{Fe}_{3} \text { and } \\
\mathrm{Th}_{7} \mathrm{Ni}_{3}\end{array}$ \\
\hline ThCo & Orthorhombic & $\begin{array}{l}a=3.74 \\
b=10.88 \\
c=4.16\end{array}$ & 4 & & $\begin{array}{l}\mathrm{Cmcm} \text { or } \\
\mathrm{Cmc}\end{array}$ & \\
\hline $\mathrm{ThCO}_{2-3}$ & Hexagonal & $\begin{array}{l}a=5.03 \\
c=24.54\end{array}$ & & & $\begin{array}{l}\mathrm{C} 6 / \mathrm{mmc} \text {, } \\
\mathrm{C} 6 \mathrm{mc} \text {, or } \\
\mathrm{c} \overline{6} 2 \mathrm{c}\end{array}$ & $\begin{array}{l}\text { True c dimension } \\
\text { is } 8 \text { or } 9 \text { times } \\
\text { the co or about } \\
200 \mathrm{~A}\end{array}$ \\
\hline $\mathrm{ThCo}_{5}$ & Hexagonal & $\begin{array}{l}a=5.01 \\
c=3.97\end{array}$ & 1 & & $\mathrm{C}_{6} / \mathrm{mmm}$ & $\begin{array}{l}\text { Isomorphous with } \\
\mathrm{CaZn}_{5}, \mathrm{ThFe}_{5} \text {, } \\
\text { and } \mathrm{ThNi}_{5}\end{array}$ \\
\hline $\mathrm{Th}_{2} \mathrm{Co}_{17}$ & Monoclinic & $\begin{array}{l}a=9.62 \\
b=8.46 \\
c=6.32 \\
\beta=99^{\circ} 6^{\prime}\end{array}$ & 2 & & $\mathrm{C} 2 / \mathrm{m}$ & $\begin{array}{l}\text { Isomorphous with } \\
\mathrm{Th}_{2} \mathrm{Fe}_{17}\end{array}$ \\
\hline
\end{tabular}

\section{References}

(1) Florio, J. V., Baenziger, N. C., and Rundle, R. E., "Compounds of Thorium with Transition Metals II. Systems With Iron, Cobalt, and Nickel", Acta Cryst., 9, 367-72 (1956). 


\section{THORIUM-COPPER}

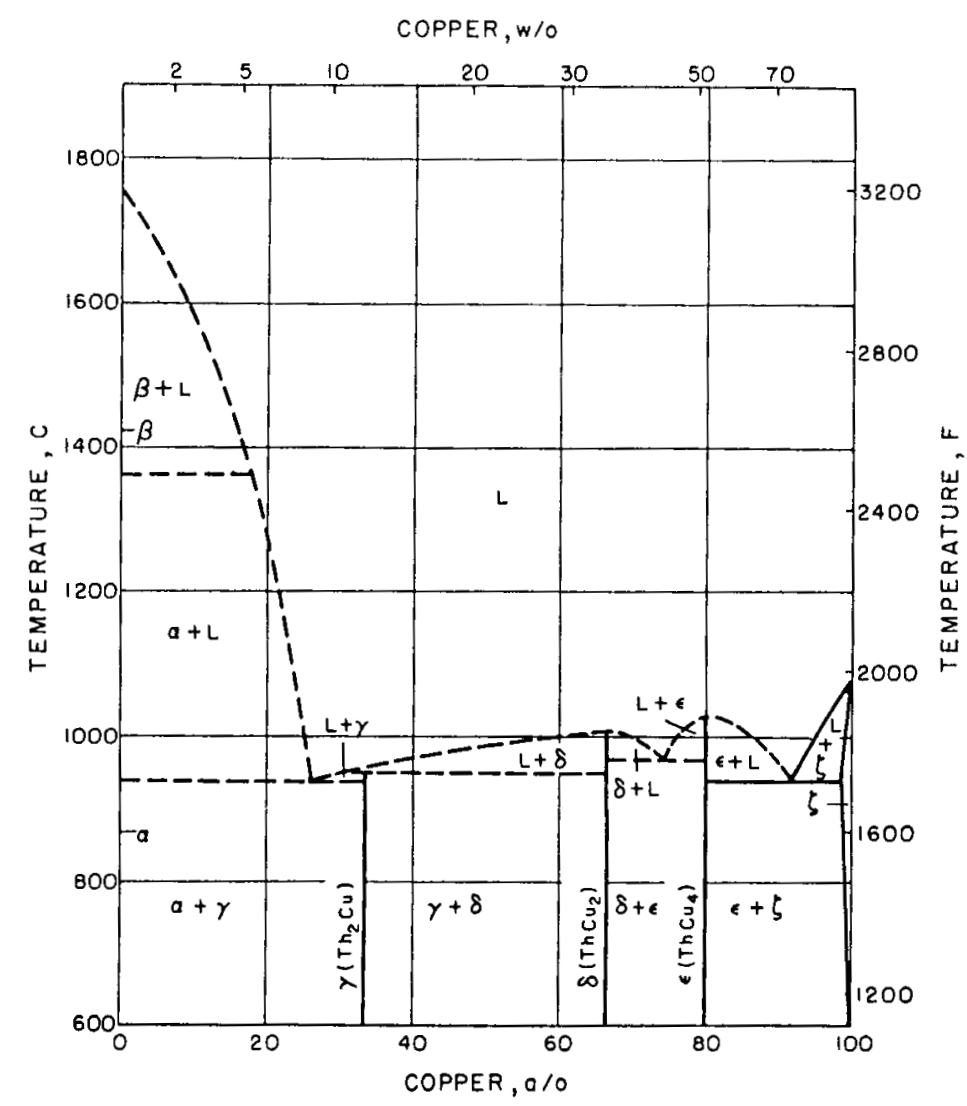

\section{The Constitutional Diagram}

The thorium-copper diagram which is shown is based on data of Wilhelm(1), Snow and Rundle (2), Grube and Botzenhardt (3), and Murray(4). There appear to be three compounds in the system: $\mathrm{Th}_{2} \mathrm{Cu}, \mathrm{ThCu}_{2}$, and $\mathrm{ThCu}_{4}$.

Raube and Engel(5), who have a different view of the nature of the system, report four compounds, nominally $\mathrm{Th}_{3} \mathrm{Cu}_{5}, \mathrm{ThCu}_{3}, \mathrm{ThCu}_{5}$, and $\mathrm{ThCu}_{6}$.

The compounds in this system are pyrophoric(5).

\section{Crystallography}

The tabulated data are from Snow and Rundle(2).

\begin{tabular}{|c|c|c|c|c|c|c|c|}
\hline \multirow[b]{3}{*}{ Phase } & \multicolumn{3}{|c|}{ Unit Cell } & \multirow{2}{*}{\multicolumn{2}{|c|}{$\begin{array}{l}\text { Density, } \\
\mathrm{g} / \mathrm{cm}^{3} \\
\end{array}$}} & \multirow{3}{*}{$\begin{array}{l}\text { Space } \\
\text { Group }\end{array}$} & \multirow[b]{3}{*}{ Remarks } \\
\hline & & Dimensions, & $\begin{array}{c}\text { Number } \\
\text { of }\end{array}$ & & & & \\
\hline & Type & $\mathrm{A}$ & Molecules & X-Ray & Other & & \\
\hline $\begin{array}{l}\text { Gamma } \\
\qquad\left(\mathrm{Th}_{2} \mathrm{Cu}\right)\end{array}$ & $\begin{array}{l}\text { Bc tetrago- } \\
\text { nal }\end{array}$ & $\begin{array}{l}a=7.29 \\
c=5.75\end{array}$ & 4 & & & & $\begin{array}{l}\text { C16-type struc- } \\
\text { ture, isomorphous } \\
\text { with } \mathrm{CuA1} \mathrm{A}_{2}\end{array}$ \\
\hline $\begin{array}{l}\text { Delta } \\
\qquad\left(\mathrm{ThCu}_{2}\right)\end{array}$ & Hexagonal & $\begin{array}{l}a=4.36 \\
c=3.48\end{array}$ & 1 & & & $\mathrm{P} 6 / \mathrm{mmm}$ & $\begin{array}{l}\text { C32-type struc- } \\
\text { ture, isomorphous } \\
\text { with } \mathrm{AlB}_{2}\end{array}$ \\
\hline
\end{tabular}

Epsilon Not availa-

$\left(\mathrm{ThCu}_{4}\right)$ ble 
(1) Wilhelm, H. A., Newton, A. S., Daane, A. H., and Neher, C., "Thorium Metallurgy", CT-3714 (February, 1946).

(2) Snow, A. I., and Rundle, R. E., unpublished information (July and November, 1949).

(3) Grube, G., and Botzenhardt, L., Z. Elektrochem., 48, 422 (1942).

(4) Murray, J. R., "The Crystal Structure of Some Thorium Compounds", J. Inst. Metals, $\underline{4}, 91-6(1955)$.

(5) Raub, E., and Engel, M., Z. Elektrochem., 49, 487-93 (1943).

\section{THORIUM-GOLD}

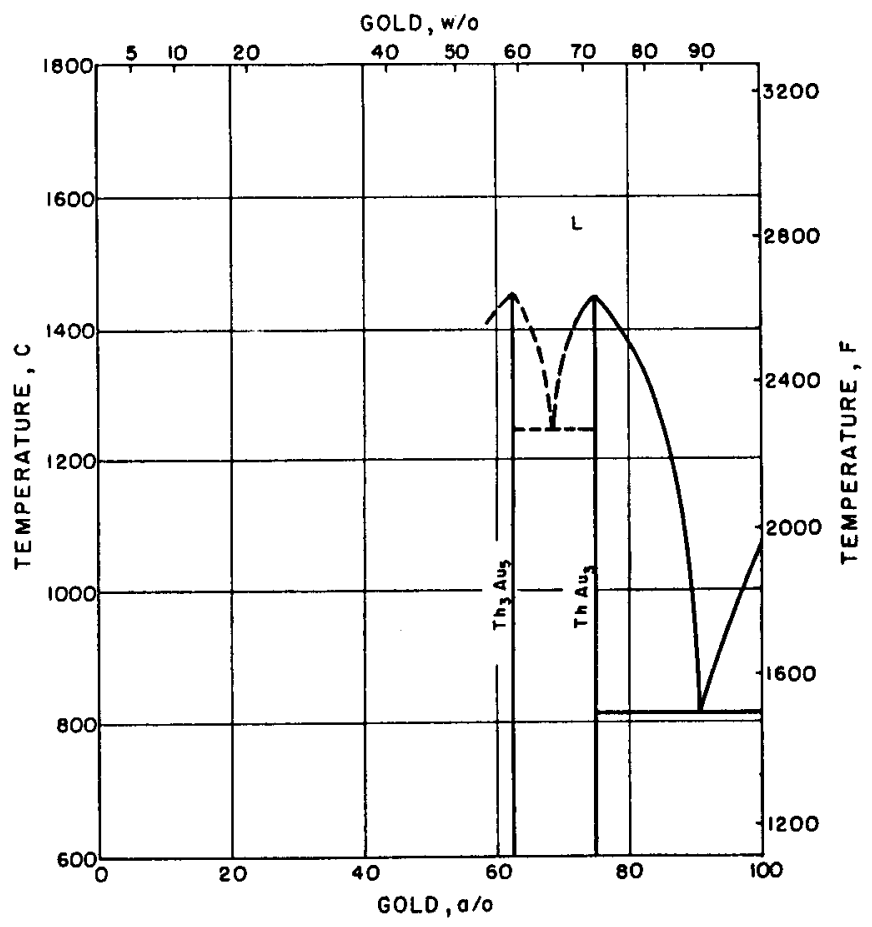

The Constitutional Diagram

The portion of the diagram shown is from Raub and Engel(1). The crystal structure of an additional pyrophoric compound, Th2Au, has been reported by Murray (2).

The solubility in gold is less than $0.5 \mathrm{w} / \mathrm{o}$ thorium. (1)

The compounds shown in the diagram tend to be pyrophoric. (3)

\section{Crystallography}

The data below for ThzAu are from Murray (2).

\begin{tabular}{|c|c|c|c|c|c|c|}
\hline \multirow[b]{3}{*}{ Phase } & \multicolumn{3}{|c|}{ Unit Cell } & \multirow[b]{2}{*}{$\begin{array}{c}\text { Density, } \\
\mathrm{g} / \mathrm{cm}^{3} \\
\end{array}$} & \multirow{3}{*}{$\begin{array}{l}\text { Space } \\
\text { Group }\end{array}$} & \multirow[b]{3}{*}{ Remarks } \\
\hline & & Dimensions, & $\begin{array}{c}\text { Number } \\
\text { of }\end{array}$ & & & \\
\hline & Type & $\mathrm{A}$ & Molecules & X-Ray Other & & \\
\hline $\mathrm{Th}_{2} \mathrm{Au}$ & Tetragonal & $\begin{array}{l}a=7.42 \\
c=5.95\end{array}$ & 4 & & $\begin{array}{l}\mathrm{I} 4 / \\
\mathrm{mcm}\end{array}$ & $\begin{array}{l}\text { Isomorphous } \\
\text { with } \mathrm{CuAl}_{2}, \\
\mathrm{Th}_{2} \mathrm{Al} \text {, and } \\
\mathrm{Th}_{2} \mathrm{Ag}\end{array}$ \\
\hline
\end{tabular}


References

(1) Raub, E., and Engel, M., "Alloys of Thorium With Copper, Silver, and Gold", Z.

Electrochem., 49, 487-93 (1943).

(2) Murray, J. R., "The Crystal Structure of Some Thorium Compounds", J. Inst. Metals, 4, $91-6$ (1955).

(3) Raub, E., and Engel, M., "Self-Igniting Alloys", Metallforschung, 2, $115-19$ (1947).

\section{THORIUM-HAFNIUM}

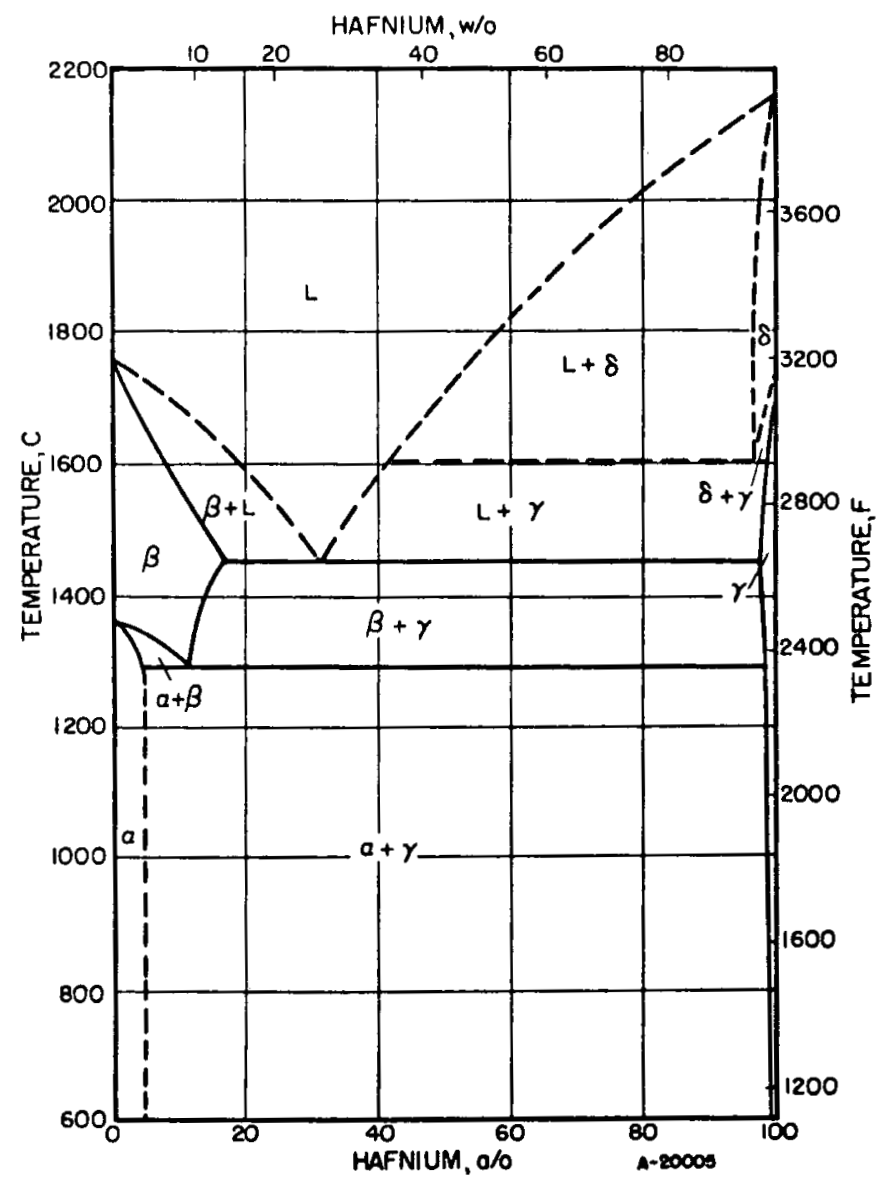

The Constitutional Diagram

The diagram shown is from Loomis and Carlson(1). A variety of techniques were employed in the determination.

Solubility of hafnium in beta thorium is approximately 17 a/o at the eutectic temperature. Solubility in the terminal alpha, gamma, and delta phases is limited.

\section{Crystallography}

There are no intermetallic compounds in the system thorium-hafnium.

\section{References}

(1) Loomis, B. A., and Carlson, O. N., "Thorium and Hafnium Phase Diagram", ISC-766 (1956); Trans. Am. Soc. Metals, 50 (1958). 


\section{THORIUM-HYDROGEN}

Two hydrides have been identified: $\mathrm{ThH}_{2}(1)$ and $\mathrm{Th}_{4} \mathrm{H}_{15}(2)$.

A study of dissociation pressures in the thorium- $\mathrm{ThH}_{2}$ range has revealed a solubility in thorium of about 13 a/o hydrogen at $650 \mathrm{C}$ and about 23 a/o hydrogen at $900 \mathrm{C} .{ }^{\text {(3) }}$

The solubility range of the dihydride, $\mathrm{ThH}_{2}$, appears to be limited. (1)

\section{Crystallography} below.

The crystallography of the hydrides $\mathrm{ThH}_{2}$ and $\mathrm{Th}_{4} \mathrm{H}_{15}$ is summarized in the tabulation

Rundle, Schull, and Wollan (1) have studied $\mathrm{ThH}_{2}$ and $\mathrm{ThD}_{2}$ and have determined the lattice constants and thorium-atom positions by $\mathrm{X}$-ray diffraction, the hydrogen-atom positions by neutron diffraction.

The structure of $\mathrm{ThH}_{2}$ is tetragonal, and there appears no likelihood that it will prove to be monoclinic, as did the "pseudo-tetragonal" $\mathrm{ThC}_{2}$. The structure is of the distortedfluorite type. (1)

The data for $\mathrm{Th}_{4} \mathrm{H}_{15}$ are from Zachariasen $(2)$.

\begin{tabular}{|c|c|c|c|c|c|c|c|}
\hline \multirow[b]{3}{*}{ Phase } & \multicolumn{3}{|c|}{ Unit Cell } & \multirow{2}{*}{\multicolumn{2}{|c|}{$\begin{array}{l}\text { Density, } \\
\mathrm{g} / \mathrm{cm}^{3}\end{array}$}} & \multirow{3}{*}{$\begin{array}{l}\text { Space } \\
\text { Group }\end{array}$} & \multirow[b]{3}{*}{ Remarks } \\
\hline & & Dimensions, & $\begin{array}{c}\text { Number } \\
\text { of }\end{array}$ & & & & \\
\hline & Type & $\mathrm{A}$ & Molecules & X-Ray & Other & & \\
\hline $\mathrm{ThH}_{2}$ & $\begin{array}{l}\mathrm{Bc} \\
\text { tetragonal }\end{array}$ & $\begin{array}{l}a=4.10 \pm 0.03 \\
c=5.03 \pm 0.03\end{array}$ & 2 & 9.20 & & & $\begin{array}{l}\text { Isomorphous with } \\
\mathrm{ZrH}_{2}\end{array}$ \\
\hline $\mathrm{Th}_{4} \mathrm{H}_{15}$ & Cubic & $a=9.11 \pm 0.02$ & 4 & & & $1 \overline{4} 3 \mathrm{~d}$ & \\
\hline
\end{tabular}

\section{References}

(1) Rundle, R. E., Schull, C. G., and Wollan, E. O., "The Crystal Structure of Thorium and Zirconium Dihydrides by X-ray and Neutron Diffraction", Acta Cryst., 5, $22-6$ (1952).

(2) Zachariasen, W. H., "Crystal Chemical Studies of the 5f-Series of Elements XIX. The Crystal Structure of the Higher Thorium Hydride", Acta Cryst., 6, 393-5 (1953).

(3) Mallett, M. W., and Campbell, Ivor, "The Dissociation Pressures of the Dihydride in the Thorium-Thorium Dihydride System", J. Am. Chem. Soc., 73, 4850-2 (1951).

\section{THORIUM-INDIUM}

The solubility of thorium in liquid indium is reported to be undetectable at $650 \mathrm{C}$ and to be 0.25 and $0.95 \mathrm{w} / \mathrm{o}$ at 800 and $900 \mathrm{C}$, respectively.

\section{Crystallography}

No data are available.

\section{Reference}

(1) Hayes, E. E., and Gordon, P., J. Met. and Cer., TID-65, 130-41 (July, 1948).

Classified. 


\section{THORIUM-IRIDIUM}

A compound, $\operatorname{ThIr}_{2}$, has been identified. (1) No other data are available.

Crystallography

Data for $\operatorname{ThIr}_{2}(1)$ are given below.

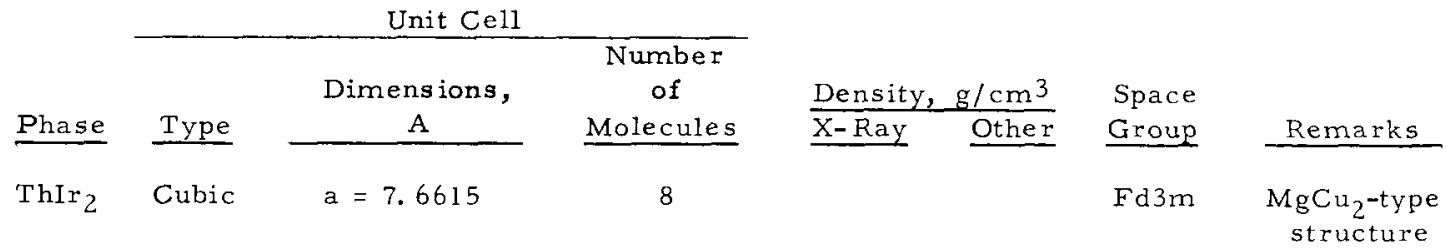

\section{Reference}

(1) Dwight, A. E., Downey, J. M., and Conner, R. A., Jr., "The Laves Phases ThOs? and $\operatorname{ThIr}_{2}{ }^{\prime \prime}$, submitted to J. Metals (October 7, 1957).

\section{THORIUM-IRON}

There are four intermetallic compounds in the thorium-iron system: $\mathrm{Th}_{7} \mathrm{Fe}_{3}, \mathrm{ThFe}_{3}$, ThFe5, and $\mathrm{Th}_{2} \mathrm{Fe}_{17}(1)$.

The compound $\mathrm{Th}_{7} \mathrm{Fe}_{3}$ appears to form by peritectic reaction between 850 and $1000 \mathrm{C}$. (2) A eutectic has been reported at 46 a/o iron and $860 \mathrm{C}$. (3) This composition is between $\mathrm{Th}_{7} \mathrm{Fe}_{3}$ and the next compound, $\mathrm{ThFe}_{3}$.

There is evidence of some solubility of iron in thorium(2) and of thorium in iron(4), but the regions of both solid solutions are limited.

\section{Crystallography}

The data given in the tabulation below are from Florio, Baenziger, and Rundle(1).

It is reported(1) that $\mathrm{Th}_{2} \mathrm{Fe}_{17}, \mathrm{Th}_{2} \mathrm{Co}_{17}, \mathrm{Th}_{2} \mathrm{Ni}_{17}$, and $\mathrm{ThMn}_{12}$ are all related even though different crystal classes are represented. The structures appear to be based on the $\mathrm{MgZn}_{5}$ lattice in which thorium replaces magnesium and the transition element replaces zinc. It is proposed that by systematic replacement of particular thorium atoms in the $\mathrm{MgZn}_{5}$ lattice with pairs of transition element atoms, the superlattices of hexagonal $\mathrm{Th}_{2} \mathrm{Ni}_{17}$, monoclinic $\mathrm{Th}_{2} \mathrm{Fe}_{17}$, and $\mathrm{Th}_{2} \mathrm{Co}_{17}$, and body-centered tetragonal $\mathrm{ThMn}_{12}$ can be derived.

\begin{tabular}{|c|c|c|c|c|c|c|}
\hline \multirow[b]{3}{*}{ Phase } & \multicolumn{3}{|c|}{ Unit Cell } & \multirow[b]{2}{*}{$\begin{array}{c}\text { Density, } \\
\mathrm{g} / \mathrm{cm}^{3} \\
\end{array}$} & \multirow{3}{*}{$\begin{array}{l}\text { Space } \\
\text { Group } \\
\end{array}$} & \multirow[b]{3}{*}{ Remarks } \\
\hline & \multirow[b]{2}{*}{ Type } & \multirow{2}{*}{$\begin{array}{c}\text { Dimensions, } \\
\mathrm{A} \\
\end{array}$} & \multirow{2}{*}{$\begin{array}{c}\begin{array}{c}\text { Number } \\
\text { of } \\
\text { Molecules }\end{array} \\
\end{array}$} & & & \\
\hline & & & & X-Ray Other & & \\
\hline $\mathrm{Th}_{7} \mathrm{Fe}_{3}$ & Hexagonal & $\begin{array}{l}a=9.85 \\
c=6.15\end{array}$ & 2 & ' & $\mathrm{c} 6 \mathrm{mc}$ & $\begin{array}{c}\text { Isomorphous } \\
\text { with } \mathrm{Th}_{7} \mathrm{Co}_{3} \\
\text { and } \mathrm{Th}_{7} \mathrm{Ni}_{3}\end{array}$ \\
\hline $\mathrm{ThFe}_{3}$ & Hexagonal & $\begin{array}{l}a=5.22 \\
c=24.96\end{array}$ & 9 & & $\mathrm{c} 6 \mathrm{~m} 2$ & \\
\hline ThFe 5 & Hexagonal & $\begin{array}{l}a=5.13 \\
c=4.02\end{array}$ & 1 & & $\begin{array}{l}\mathrm{C} 6 / \\
\mathrm{mmm}\end{array}$ & $\begin{array}{l}\text { Isomorphous } \\
\text { with CaZn } \\
\text { ThCo } \\
\mathrm{ThNi}_{5} \text {, and }\end{array}$ \\
\hline $\mathrm{Th}_{2} \mathrm{Fe}_{17}$ & Monoclinic & $\begin{array}{l}a=9.68 \\
b=8.56 \\
c=6.46 \\
\beta=99^{\circ} 20^{\prime}\end{array}$ & 2 & & $\mathrm{C} 2 / \mathrm{m}$ & $\begin{array}{l}\text { Isomorphous } \\
\text { with } \mathrm{Th}_{2} \mathrm{Co}_{17}\end{array}$ \\
\hline
\end{tabular}


(1) Florio, J. V., Baenziger, N. C., and Rundle, R. E., "Compounds of Thorium With Transition Metals II. Systems With Iron, Cobalt, and Nickel", Acta Cryst., 9 , $367-72(1956)$.

(2) Foote, F., unpublished information (March, 1945).

(3) Wilhelm, H. A., Newton, A. S., Daane, A. H., and Neher, C., "Thorium Metallurgy", CT-3714 (February, 1956).

(4) Russell, H. W., unpublished information (August, 1946).

\section{THORIUM-LANTHANUM}

Peterson $(1)$ studied a series of thorium-lanthanum alloys metallographically and found that lanthanum and thorium exhibit extensive solubility. The alloys were prepared by co-reduction at 1000 to $1400 \mathrm{C}$.

\section{Crystallography}

There are no compounds in this system.

$\underline{\text { References }}$

(1) Peterson, D., and Mickelson, R., unpublished information (March 31, 1952).

\section{THORIUM-LEAD}

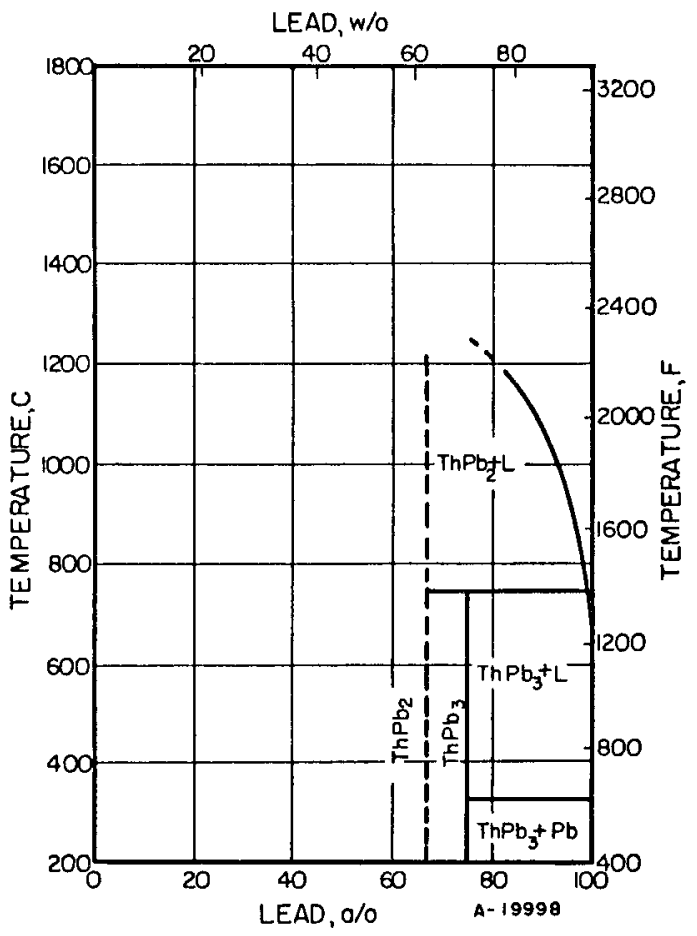




\section{The Constitutional Diagram}

A portion of the diagram has been determined by Bryner(1). The compound $\mathrm{ThPb}_{2}$ may show a limited solubility range. Weiner ${ }^{(2)}$ has also investigated this system and reported the existence of two pyrophoric compounds $\mathrm{ThPb}$ and $\mathrm{ThPb}_{3}$. Metallographic examination showed that the solubility of lead in thorium was less than 1 a/o at $625 \mathrm{C}$. (2)

The compound $\mathrm{ThPb}_{3}$ has a density of $12.3 \mathrm{~g} / \mathrm{cm}^{3}$. (1)

\section{Crystallography}

No data are available on the crystal structure of the compounds.

\section{References}

(1) Bryner, J. S., and Teitel, R. J., private communication (1956).

(2) Weiner, R. T., United Kingdom, unpublished information (1956).

\section{THORIUM-M AGNESIUM}

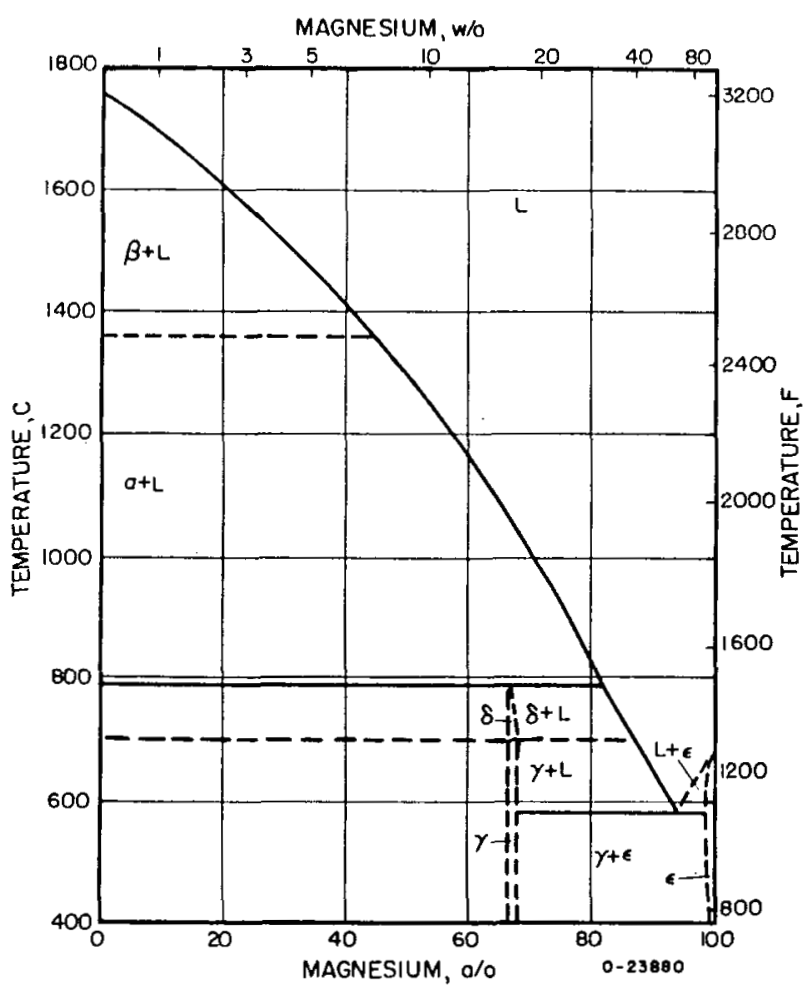

The Constitutional Diagram

The diagram shown is from Peterson $(1,2)$. He reports a single compound, $\mathrm{ThMg}_{2}$, which transforms from hexagonal to cubic symmetry at about $700 \mathrm{C}$. The cubic phase decomposes peritectically at about $790 \mathrm{C}$. The composition of the compound was determined by chemical analysis of crystals of the compound mechanically separated from the matrix of thorium-magnesium alloys. 
This $\mathrm{ThMg}_{2}$ phase reported by Peterson apparently corresponds to the cubic $\mathrm{ThMg}_{5}$ phase reported by Yamamota, Levinson, and Rostoker(3), who report an additional unidentified compound of higher thorium composition. The composition $\mathrm{ThMg}_{5}$ was determined by means of quantitative metallography.

The eutectic composition is reported $(3)$ to be approximately 8 a/o thorium with maximum solubility of thorium in magnesium, $0.5 \mathrm{a} / \mathrm{o}$, occurring at the eutectic temperature. The solubility decreases to 0.1 a/o at $300 \mathrm{C}$. (3)

The solubility of magnesium in thorium appears to be low (1), since no change in the thorium lattice constant was observed in thorium-magnesium alloys at room temperature.

\section{Crystallography}

The data tabulated below are from Peterson(1). The delta $\mathrm{ThMg}_{2}$ phase is stable above about $700 \mathrm{C}$; the cubic gamma $\mathrm{ThMg}_{2}$ is stable below this temperature.

\begin{tabular}{|c|c|c|c|c|c|c|c|}
\hline \multirow[b]{3}{*}{ Phase } & \multicolumn{3}{|c|}{ Unit Cell } & \multirow{2}{*}{\multicolumn{2}{|c|}{$\begin{array}{l}\text { Density, } \\
\mathrm{g} / \mathrm{cm}^{3} \\
\end{array}$}} & \multirow{3}{*}{$\begin{array}{l}\text { Space } \\
\text { Group }\end{array}$} & \multirow[b]{3}{*}{ Remarks } \\
\hline & \multirow[b]{2}{*}{ Type } & \multirow{2}{*}{$\begin{array}{c}\text { Dimensions, } \\
\mathrm{A} \\
\end{array}$} & \multirow{2}{*}{$\begin{array}{c}\begin{array}{c}\text { Number } \\
\text { of } \\
\text { Molecules }\end{array} \\
\end{array}$} & & & & \\
\hline & & & & X-Ray & Other & & \\
\hline $\begin{array}{l}\text { Gamma } \\
\qquad\left(\mathrm{ThMg}_{2}\right)\end{array}$ & $\begin{array}{l}\text { Hexag- } \\
\text { onal }\end{array}$ & $\begin{array}{l}a=6.086 \\
c=19.64\end{array}$ & & & & $\mathrm{P}_{3} / \mathrm{mmc}$ & $\begin{array}{l}\text { Isomorphous with } \\
\mathrm{Ni}_{2} \mathrm{Mg}\end{array}$ \\
\hline $\begin{array}{l}\text { Delta } \\
\qquad\left(\mathrm{ThMg}_{2}\right)\end{array}$ & Cubic & $a=8.570$ & 8 & & & $\mathrm{Fd} 3 \mathrm{~m}$ & $\begin{array}{l}\text { Isomorphous with } \\
\mathrm{Cu}_{2} \mathrm{Mg}\end{array}$ \\
\hline
\end{tabular}

\section{References}

(1) Peterson, D., unpublished information (March, 1954).

(2) Peterson, D. R., Diljak, P. F., and Vold, C. L., "The Structure of Thorium-Magnesium Intermetallic Compounds", Acta Cryst., 1-90, 1036 (1956).

(3) Yamamoto, A. S., Levinson, D. W., and Rostoker, W., "Research on Phase Relationships in Magnesium Alloys", WADC TN-649 (November 1, 1955).

\section{THORIUM-M ANG ANESE}

There is evidence of three intermetallic compounds: $\mathrm{ThMn}_{2}, \mathrm{Th}_{6} \mathrm{Mn}_{23}$, and $\mathrm{ThMn}_{12}$ (1) $^{(1)}$

Wilhelm $(2)$ reports that a eutectic occurs at $911 \mathrm{C}$ at a composition greater than 20 a/0 manganese. Addition of $1 \mathrm{a} / \mathrm{o}$ manganese lowers the thorium lattice constant to $\mathrm{a}=5.0746 \mathrm{~A} .(2)$

\section{Crystallography}

The data tabulated below are from Florio, Rundle, and Snow (1).

There is a similarity in the structures of $\mathrm{Th}_{6} \mathrm{Mn}_{23}$ and $\mathrm{ThMn}_{12}{ }^{(1)}$. In both structures, body-centered cubes of manganese atoms tie thorium atoms together. In the $\mathrm{Th}_{6} \mathrm{Mn}_{23}$ structure, each such cube has a thorium atom attached to each face, while in $\mathrm{ThMn}_{12}$ only two opposite faces are bound to thorium.

Florio, Baenziger, and Rundle(3) report that $\mathrm{ThMn}_{12}, \mathrm{Th}_{2} \mathrm{Fe}_{17}, \mathrm{Th}_{2} \mathrm{Co}_{17}$, and $\mathrm{Th}_{2} \mathrm{Ni}_{17}$ are all related, and, while they represent different classes of crystals, appear to be based on the $\mathrm{MgZn}_{5}$ lattice. A more complete discussion of their relationship is presented in "The System Thorium-Iron". 


\begin{tabular}{|c|c|c|c|c|c|c|c|}
\hline \multirow[b]{3}{*}{ Phase } & \multicolumn{3}{|c|}{ Unit Cell } & & & \multirow{3}{*}{$\begin{array}{l}\text { Space } \\
\text { Group }\end{array}$} & \multirow[b]{3}{*}{ Remarks } \\
\hline & \multirow[b]{2}{*}{ Type } & \multirow{2}{*}{$\begin{array}{c}\text { Dimensions, } \\
\mathrm{A} \\
\end{array}$} & \multirow{2}{*}{$\begin{array}{c}\begin{array}{c}\text { Number } \\
\text { of } \\
\text { Molecules }\end{array} \\
\end{array}$} & \multicolumn{2}{|c|}{$\begin{array}{l}\text { Density, } \\
\mathrm{g} / \mathrm{cm}^{3}\end{array}$} & & \\
\hline & & & & X-Ray & Other & & \\
\hline $\mathrm{ThMn}_{2}$ & $\begin{array}{c}\text { Hexag- } \\
\text { onal }\end{array}$ & $\begin{array}{c}a=5.48 \pm \\
0.01 \\
c=8.95 \pm \\
0.02\end{array}$ & & & & $\mathrm{~Pb}_{3} / \mathrm{mmc}$ & $\begin{array}{l}\text { C14-type } \\
\text { struc- } \\
\text { ture, } \\
\text { isomor- } \\
\text { phous } \\
\text { with } \\
\mathrm{MgZn}_{2}\end{array}$ \\
\hline $\mathrm{Th}_{6} \mathrm{Mn}_{23}$ & $F c c$ & $a=\begin{array}{c}12.523 \pm \\
0.001\end{array}$ & 4 & 9.03 & $\begin{array}{c}9.02 \pm \\
0.05\end{array}$ & $F \mathrm{~m} 3 \mathrm{~m}$ & $\begin{array}{c}\text { Density for } \\
81.8 \text { a/o } \\
\text { manga- } \\
\text { nese alloy }\end{array}$ \\
\hline $\operatorname{ThMn} 12$ & $\begin{array}{c}\text { Tetrag- } \\
\text { onal }\end{array}$ & $\begin{array}{c}a=8.74 \pm \\
0.01 \\
c=4.95 \pm \\
0.01\end{array}$ & 2 & & 8.12 & $14 / \mathrm{mmm}$ & \\
\hline
\end{tabular}

\section{References}

(1) Florio, J. V., Rundle, R. E., and Snow, A. I., "Compounds of Thorium With Transition Metals" (AECD-3249), Acta Cryst. , 5, 449-57 (1952).

(2) Wilhelm, H. A., Newton, A. S., Daane, A. H., and Neher, C., "Thorium Metallurgy", CT-3714 (February, 1946).

(3) Florio, J. V., Baenziger, N. C., and Rundle, R. E., "Compounds of Thorium With Tran. ition Metals: II. Systems With Iron, Cobalt, and Nickel", Acta Cryst., 9, 367-72 (1956).

\section{THORIUM-MERCURY}

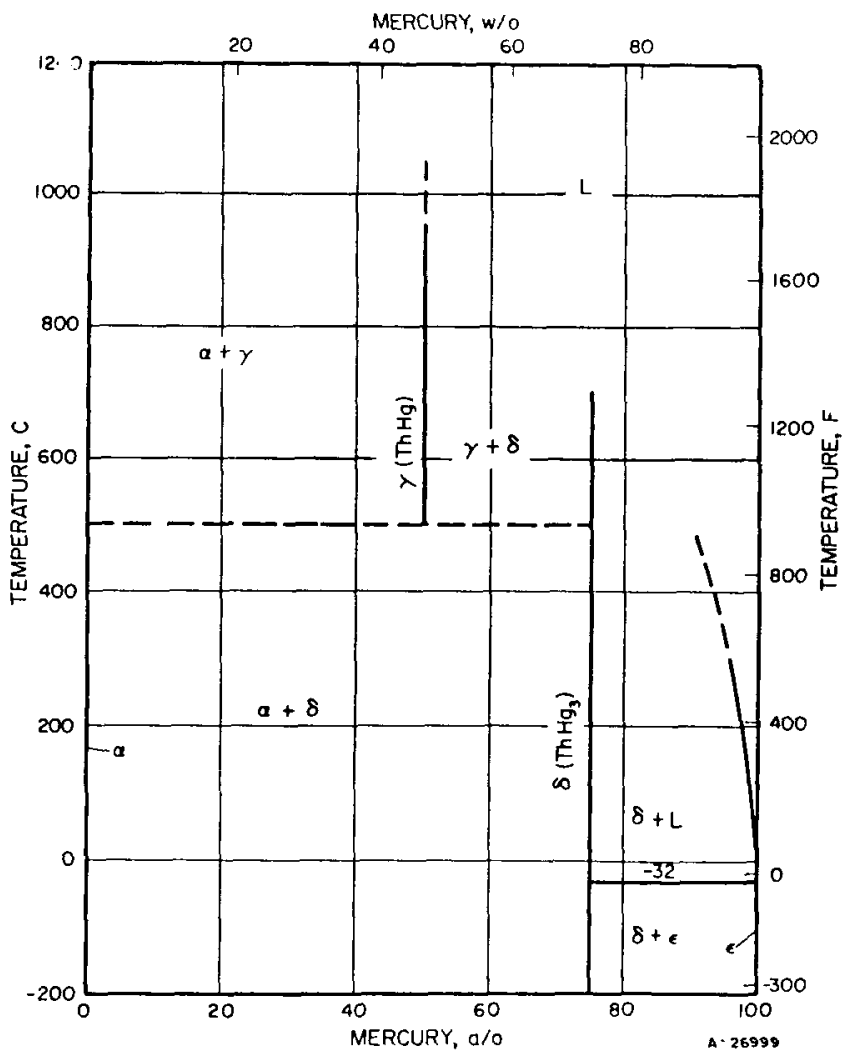




\section{The Constitutional Diagram}

The diagram shown is from Domagala(1). Data were obtained by employing a closed system. The alloy specimens, which were enclosed in small capsules, attained equilibrium with the vapor pressure of mercury as dictated by pressure and composition.

Two compounds appear in the system, ThHg and $\mathrm{ThHg}_{3}$. The ThHg decomposes eutectoidally at some temperature between 400 and $600 \mathrm{C}$. (1)

Solubility of thorium in liquid mercury is given as $5 \mathrm{w} / 0$ at $300 \mathrm{C}$. (1) The solubility at $25 \mathrm{C}$ has been reported as $0.154 \mathrm{w} / 0$ thorium. (2)

The solubility of mercury in solid thorium appears negligible.

\section{Crystallography}

The data tabulated for $\mathrm{ThHg}_{3}$ are from Domagala(1) and Baenziger (3). Baenziger gives cell dimensions of $\mathrm{a}=3.38 \mathrm{~A}$ and $\mathrm{c}=4.92 \mathrm{~A}$, rather than the values given which are from Domagala. Domagala reports that $\mathrm{ThHg}_{3}$ exhibits a disordered structure with only two atoms per unit cell. In contradiction to the work of Baenziger, Domagala reports a very restricted homogeneity range for $\mathrm{ThHg}_{3}$ since alloys on either side of the phase showed identical lattice parameters.

Data for ThHg are from Domagala(1). Weak superlattice lines were exhibited by this phase.

\begin{tabular}{|c|c|c|c|c|c|c|c|}
\hline \multirow[b]{3}{*}{ Phase } & \multicolumn{3}{|c|}{ Unit Cell } & \multirow{2}{*}{\multicolumn{2}{|c|}{$\begin{array}{c}\text { Density, } \\
\mathrm{g} / \mathrm{cm}^{3} \\
\end{array}$}} & \multirow{3}{*}{$\begin{array}{l}\text { Space } \\
\text { Group }\end{array}$} & \multirow[b]{3}{*}{ Remarks } \\
\hline & \multirow[b]{2}{*}{ Type } & \multirow{2}{*}{$\begin{array}{c}\text { Dimensions, } \\
\mathrm{A} \\
\end{array}$} & \multirow{2}{*}{$\begin{array}{c}\text { Number } \\
\text { of } \\
\text { Molecules }\end{array}$} & & & & \\
\hline & & & & X-Ray & Other & & \\
\hline $\begin{array}{l}\text { Gamma } \\
\text { (ThHg) }\end{array}$ & $\mathrm{Fcc}$ & $a=4.80$ & & & & & \\
\hline $\begin{array}{l}\text { Delta } \\
\qquad\left(\mathrm{ThHg}_{3}\right)\end{array}$ & $\begin{array}{c}\text { Hexag- } \\
\text { onal }\end{array}$ & $\begin{array}{l}a=3.361 \\
c=4.905\end{array}$ & $1 / 2$ & 14.2 & & & $\begin{array}{l}\text { Appears isomorphous } \\
\text { with } \mathrm{UHg}_{3}\end{array}$ \\
\hline
\end{tabular}

\section{References}

(1) Domagala, R. F., Elliott, R. P., and Rostoker, W., "The System Mercury-Thorium", to be published, J. Metals (1958).

(2) Park, W. G., and Prime, G. E., J. Am. Chem. Soc., 58, 1413 (1936).

(3) Baenziger, N. C., Rundle, R. E., and Snow, A. I. , Acta Cryst., 9, 93 (1956).

\section{THORIUM-MOLYBDENUM}

Metallographic examination of high-molybdenum alloys showed that thorium was present as a second phase. Hence, no intermetallic compounds occur in this system. (1,2) A eutectic is reported to occur at 38 a/o $(20 \mathrm{w} / 0)$ molybdenum and $1380 \mathrm{C}$. (3)

\section{Crystallography}

No compounds occur in this system.

\section{References}

(1) Rough, F. A., private communication (1952).

(2) Pipitz, E., and Kieffer, R., Z. metallkunde, 46, 187-94 (1955).

(3) WilheIm, H. A., "Nuclear Fuels Newsletter", WASH-704 (December, 1957). Classified. 


\section{THORIUM-NICKEL}

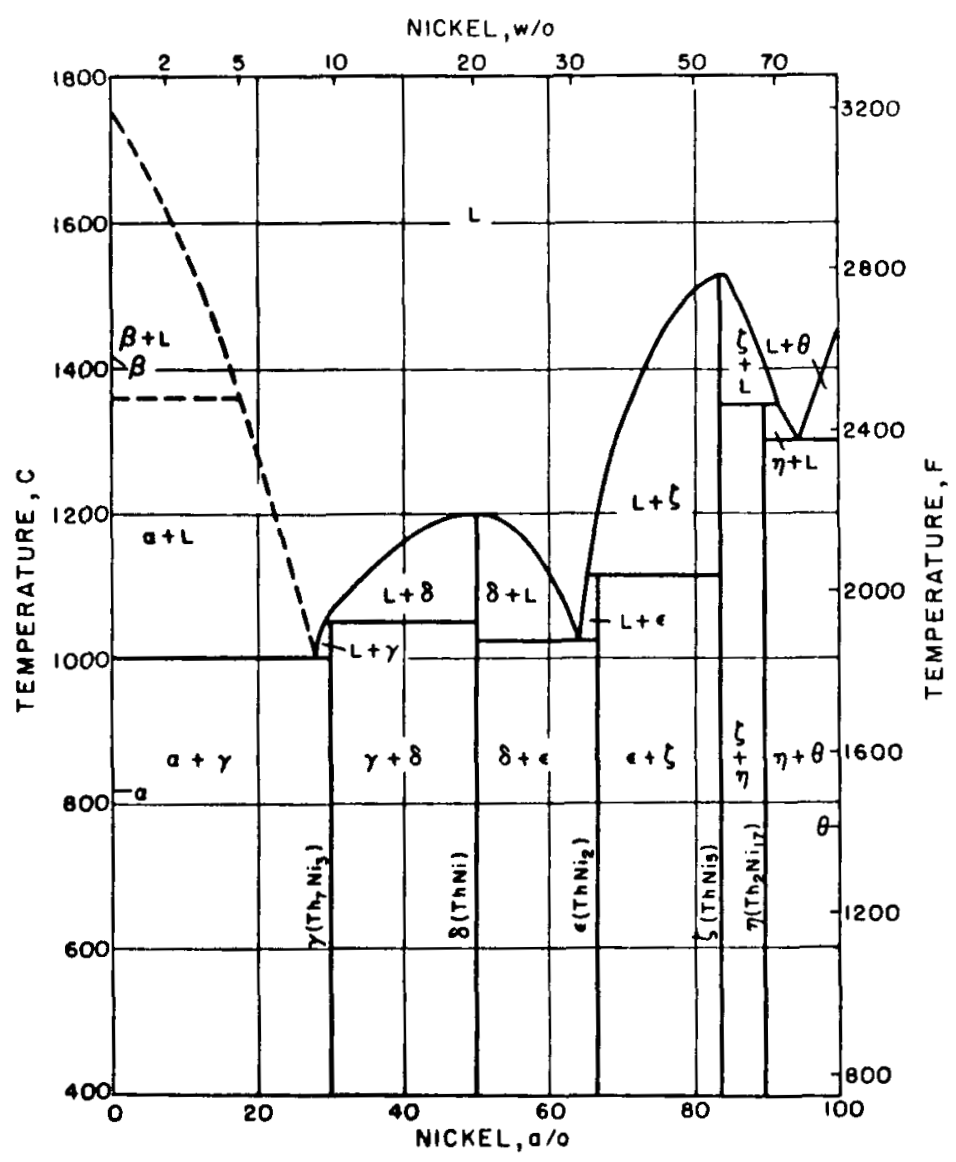

\section{The Constitutional Diagram}

The diagram which is shown is that of Horn and Wasserman (1); it has been revised to incorporate changes indicated by the work of Wilhelm and Carlson(2).

The melting points of compounds reported by Wilhelm and Carlson agree fairly well with similar data of Horn and Wasserman. The compounds in the system are $\mathrm{Th}_{7} \mathrm{Ni}_{3}$, $\mathrm{ThNi}$, $\mathrm{ThNi}_{2}, \mathrm{ThNi}_{5}$, and $\mathrm{Th}_{2} \mathrm{Ni}_{17} \cdot(2,3,4)$ Horn and $\mathrm{W}$ asserman ${ }^{(1)}$ have reported the compounds tentatively as $\mathrm{Th}_{2} \mathrm{Ni}, \mathrm{ThNi}, \mathrm{Th}_{2} \mathrm{Ni}_{5}, \mathrm{ThNi}_{5}$, and $\mathrm{ThNi}$, but this determination was not based on $\mathrm{X}$-ray examination.

Carlson (2) has shown that the lattice constant for nickel is affected little by addition of $4 \mathrm{a} / 0$ thorium. Accordingly, the solubility of thorium in nickel is slight.

\section{Crystallography}

The data tabulated are from Florio, Baenziger, and Rundle(3).

There was evidence of a range of composition in $\mathrm{ThNi}_{5}$ to perhaps $\mathrm{ThNi}_{4}{ }^{(3)}$.

It is reported (3) that $\mathrm{Th}_{2} \mathrm{Ni}_{17}, \mathrm{Th}_{2} \mathrm{Fe}_{17}, \mathrm{Th}_{2} \mathrm{Co}_{17}$, and $\mathrm{ThMn}_{12}$, although all representing different classes, are related. These structures are based on the $\mathrm{MgZn}_{5}$ lattice in which thorium replaces magnesium and the transition element replaces zinc. By systematically replacing particular thorium atoms with pairs of transition-element atoms, the superlattices of hexagonal $\mathrm{Th}_{2} \mathrm{Ni}_{17}$, monoclinic $\mathrm{Th}_{2} \mathrm{Fe}_{17}$ and $\mathrm{Th}_{2} \mathrm{Co}_{17}$, and body-centered tetragonal $\mathrm{ThMn}_{12}$ can be derived. 


\begin{tabular}{|c|c|c|c|c|c|c|c|}
\hline \multirow[b]{3}{*}{ Phase } & \multicolumn{3}{|c|}{ Unit Cell } & & & \multirow{3}{*}{$\begin{array}{l}\text { Space } \\
\text { Group }\end{array}$} & \multirow[b]{3}{*}{ Remarks } \\
\hline & \multirow[b]{2}{*}{ Type } & \multirow{2}{*}{$\begin{array}{c}\text { Dimensions, } \\
\mathrm{A} \\
\end{array}$} & \multirow{2}{*}{$\begin{array}{l}\text { Number } \\
\text { of } \\
\text { Molecules } \\
\end{array}$} & \multicolumn{2}{|c|}{$\begin{array}{l}\text { Density, } \\
\mathrm{g} / \mathrm{cm}^{3} \\
\end{array}$} & & \\
\hline & & & & $X-R a y$ & Other & & \\
\hline $\begin{array}{l}\text { Gamma } \\
\left.\qquad \mathrm{Th}_{7} \mathrm{Ni}_{3}\right)\end{array}$ & $\begin{array}{l}\text { Hexag- } \\
\text { onal }\end{array}$ & $\begin{array}{l}a=9.86 \\
c=6.23\end{array}$ & 2 & & & $\mathrm{C} 6 \mathrm{mc}$ & $\begin{array}{l}\text { Isomorphous } \\
\text { with } \mathrm{Th}_{7} \mathrm{Fe}_{3} \\
\text { and } \mathrm{Th}_{7} \mathrm{Co}_{3}\end{array}$ \\
\hline $\begin{array}{l}\text { Delta } \\
\qquad(T h N i)\end{array}$ & $\begin{array}{l}\text { Ortho- } \\
\text { rhombic }\end{array}$ & $\begin{array}{c}a=14.51 \pm \\
0.04 \\
b=4.31 \pm \\
0.02 \\
c=5.73 \pm \\
0.02\end{array}$ & 8 & . & & $\begin{array}{c}\text { Pnza or } \\
\text { Pnma }\end{array}$ & \\
\hline $\begin{array}{l}\text { Zeta } \\
\qquad\left(\mathrm{ThNi}_{5}\right)\end{array}$ & $\begin{array}{l}\text { Hexag- } \\
\text { onal }\end{array}$ & $\begin{array}{l}a=4.97 \\
c=4.01\end{array}$ & 1 & & & $\begin{array}{l}\text { C6m2, } \\
\text { C6mm } \\
\text { or C6/ } \\
\text { mmm }\end{array}$ & $\begin{array}{l}\text { Isomorphous } \\
\text { with } \mathrm{CaZn}_{5} \text {, } \\
\mathrm{ThFe}_{5} \text {, and } \\
\mathrm{ThCo}_{5}\end{array}$ \\
\hline $\left.\begin{array}{l}\text { Eta } \\
\qquad\left(\mathrm{Th}_{2} \mathrm{Ni}\right. \\
17\end{array}\right)$ & $\begin{array}{l}\text { Hexag- } \\
\text { onal }\end{array}$ & $\begin{array}{l}a=8.37 \\
c=8.14\end{array}$ & 2 & & & $\begin{array}{l}\mathrm{c} 6 / \mathrm{mmc}, \\
\mathrm{c} 6 \mathrm{mc}, \\
\text { or } \\
\mathrm{c} \overline{6} 2 \mathrm{c}\end{array}$ & \\
\hline
\end{tabular}

\section{References}

(1) Horn, L., and Wasserman, C., Z. Metallkunde, 39, 273 (1948).

(2) Wilhelm, H. A., Carlson, O. N., and Snow, A. I. , Progress Report in Metallurgy, ISC-6, 75-77 (May 1, 1947).

(3) Florio, V. F., Baenziger, N. C., and Rundle, R. E., "Compounds of Thorium with Transition Metals II. Systems with Iron, Cobalt, and Nickel", Acta Cryst., 9, 367-72 (1956).

(4) Murray, J. R., "The Crystal Structure of Some Thorium Compounds", J. Inst. MetaIs, 4, $91-6(1955)$. 


\section{THORIUM-NIOBIUM}

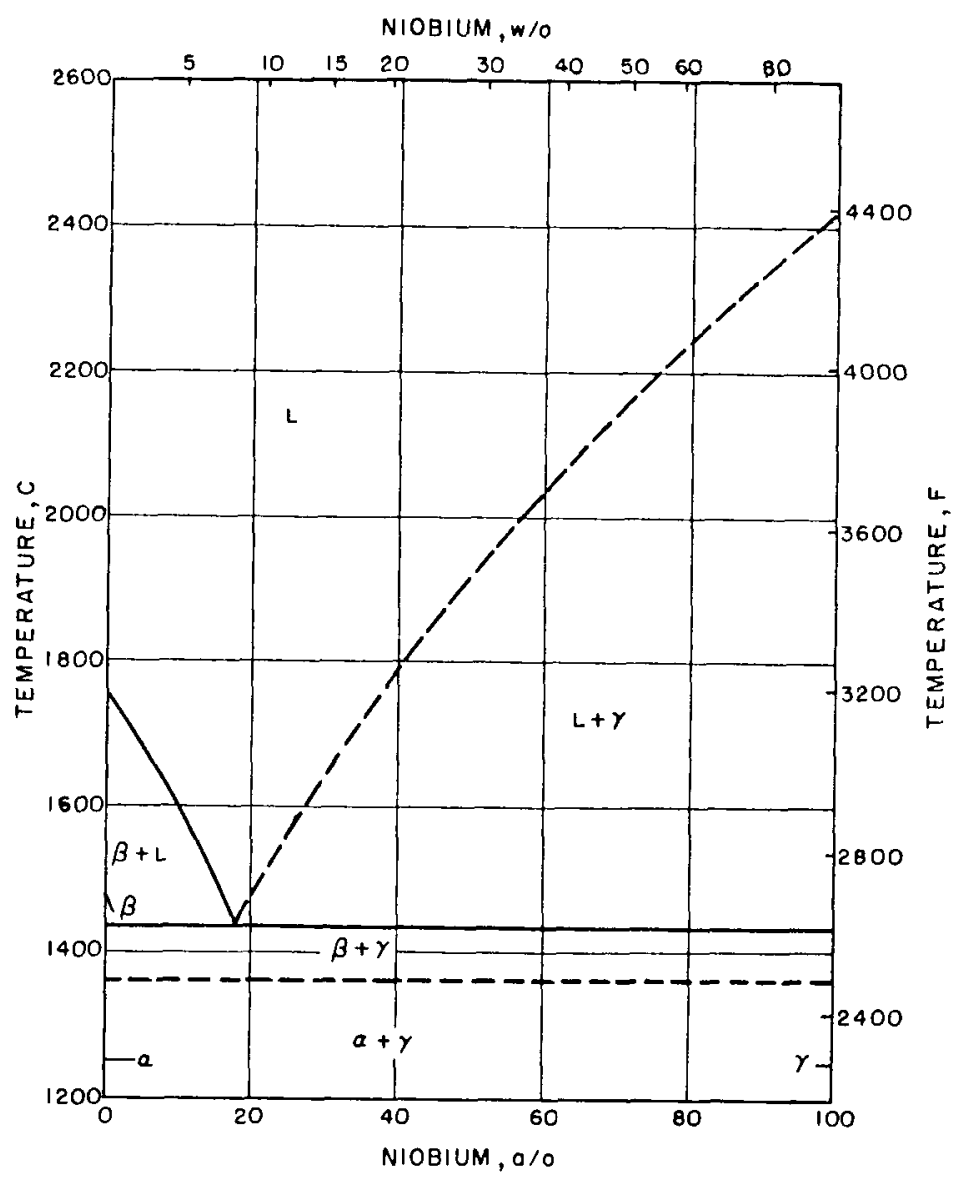

The Constitutional Diagram

The diagram which is shown has been determined by Carlson(1). The diagram is based on metallographic examination, resistance measurements, thermal analyses, and $\mathrm{X}$-ray diffraction experiments.

There are no compounds in the system, and a eutectic occurs at $1435 \mathrm{C}$ and $8 \mathrm{w} / 0$ niobium. Solid solubility is very limited in all of the terminal phases. The maximum solubility in thorium is probably less than 1 w/o niobium at $1435 \mathrm{C}$.

The lattice constants of alpha thorium are lowered from 5.089 to $5.086 \mathrm{~A}$ by additions of niobium. The data indicate that probably much less than $0.1 \mathrm{w} / 0$ niobium is soluble in alpha thorium.

High-temperature X-ray experiments indicated that the beta-to-alpha transformation in thorium appears to be lowered slightly by niobium. (1) Chiotti( 2,3$)$ reports that niobium getters thorium and that carbon raises the transformation temperature. On this basis, it appears that the effect of niobium may be largely the result of removal of carbon from solid solution.

\section{Crystallography}

There are no compounds in the thorium-niobium system.

\section{$\underline{\text { References }}$}

(1) Carlson, O. N., Dickinson, J. M., Lunt, H. E., and Wilhelm, H. A., "ThoriumColumbium and Thorium-Titanium Alloy Systems", J. Metals, 8, 132-6 (1956).

(2) Chiotti, Premo, unpublished information (November, 1953).

(3) Chiotti, Premo, private communication (March, 1954). 


\section{THORIUM-NITROGEN}

There are two thorium nitrides formed: $\operatorname{ThN}(1)$ and $\operatorname{Th}_{2} \mathrm{~N}_{3}(2,3)$. The mononitride, ThN, is stable to quite high temperatures, even under vacuum. Its melting point is $2630 \pm 50 \mathrm{C}$.

The sesquinitride, $\mathrm{Th}_{2} \mathrm{~N}_{3}$, is not stable at $1500 \mathrm{C}$ under vacuum. (2) Both nitrides are reported to react slowly at room temperature with oxygen and moisture from the air to form $\mathrm{ThO}_{2} .{ }^{(4)}$

Early reports of $\mathrm{Th}_{3} \mathrm{~N}_{4}$ are probably attributable to the identification of $\mathrm{ThN}$ or $\mathrm{Th}_{2} \mathrm{~N}_{3}$. In at least one case, a lattice constant identical with that of ThN was reported.

The solubility of nitrogen in thorium has been determined. (4) Over the temperature range 845 to $1490 \mathrm{C}$ the solubility is expressed by the following equation: $\log _{10}$ (nitrogen, w/o) $=-2405 \mathrm{~T}+0.9115$.

\section{Crystallography}

The mononitride, ThN, has the $\mathrm{NaCl}$ structure. The tabulated data are from Rundle(1). Chiotti(2) reports a lattice constant of $a=5.144 \mathrm{~A}$ for fused $\mathrm{ThN}$.

The tabulated data for $\mathrm{Th}_{2} \mathrm{~N}_{3}$ are from Zachariasen ${ }^{(3)}$. Chiotti(2) has reported similar results, giving $a=3.87$ and $c=6.16 \mathrm{~A}$.

\begin{tabular}{|c|c|c|c|c|c|c|c|}
\hline \multirow{2}{*}{ Phase } & \multicolumn{3}{|c|}{ Unit Cell } & \multirow{2}{*}{\multicolumn{2}{|c|}{$\begin{array}{c}\text { Density, } \\
\mathrm{g} / \mathrm{cm}^{3} \\
\end{array}$}} & \multirow{2}{*}{$\begin{array}{l}\text { Space } \\
\text { Group }\end{array}$} & \multirow{2}{*}{ Remarks } \\
\hline & & Dimensions, & $\begin{array}{c}\text { Number } \\
\text { of }\end{array}$ & & & & \\
\hline ThN & $F \subset c$ & $a=5.20$ & 4 & 11.56 & -- & -- & $\begin{array}{l}\text { NaCl-type structure, } \\
\text { isomorphous with } \\
\text { ThC, UC, UO, and } \\
\text { UN }\end{array}$ \\
\hline $\mathrm{Th}_{2} \mathrm{~N}_{3}$ & $\begin{array}{c}\text { Hexag- } \\
\text { onal }\end{array}$ & $\begin{array}{c}a=3.875 \pm \\
0.002 \\
c=6.175 \pm \\
0.004\end{array}$ & 1 & -- & -- & $C \overline{3} \mathrm{~m}$ & $\mathrm{La}_{2} \mathrm{O}_{3}$-type structure \\
\hline
\end{tabular}

\section{References}

(1) Rundle, R. E., "A New Interpretation of Interstitial Compounds", Acta Cryst., 1, 180-87 (1948).

(2) Chiotti, Premo, "Experimental Refractory Bodies of High-Melting Nitrides, Carbides, and Uranium Dioxide", J. Am. Cer. Soc., 35, 123-30 (1952).

(3) Zachariasen, W. H., "The Crystal Structure of $\mathrm{Th}_{2} \mathrm{~N}_{3}$ ", AECD-2090 (January 19.,- 1948).

(4) Gerds, A. F., and Mallett, M. W., J. Electrochem. Soc., 101, 175-80 (1954).

\section{THORIUM-OSMIUM}

A compound $\mathrm{ThOs}_{2}$ has been identified. (1) No other data are available.

\section{Crystallography}

The structure of $\mathrm{ThOs}_{2}$ is given below. (1)

\begin{tabular}{|c|c|c|c|c|c|c|c|}
\hline \multirow[b]{3}{*}{ Phase } & \multicolumn{3}{|c|}{ Unit Cell } & \multirow{2}{*}{\multicolumn{2}{|c|}{$\begin{array}{r}\text { Density, } \\
\mathrm{g} / \mathrm{cm}^{3} \\
\end{array}$}} & \multirow[b]{2}{*}{ Space } & \multirow[b]{3}{*}{ Remarks } \\
\hline & & Dimensions, & $\begin{array}{c}\text { Number } \\
\text { of }\end{array}$ & & & & \\
\hline & Type & $A$ & Molecules & $\overline{x-R a y}$ & Other & Group & \\
\hline $\mathrm{ThOs}_{2}$ & Cubic & $a=7.7050$ & 8 & & & $\overline{\mathrm{F}} \mathrm{d} 3 \mathrm{~m}$ & $\begin{array}{l}\mathrm{MgCu}_{2} \text {-type } \\
\text { structure }\end{array}$ \\
\hline
\end{tabular}




\section{Reference}

(1) Dwight, A. E., Downey, J. M., and Conner, R. A., Jr., "The Laves Phases ThOs 2 and ThIr ${ }^{\prime \prime}$, submitted to J. Metals (October 7, 1957).

\section{THORIUM-OXYGEN}

There appears to be only one stable oxide, $\mathrm{ThO}_{2}$. (1) It is reported to have a melting point of $3300 \pm 100 \mathrm{C}$. (3)

The solubility of oxygen in thorium is very limited(1). Iodide thorium samples, analyzed before and after reaction with oxygen at $1415 \mathrm{C}$ for $3 \mathrm{hr}$, contained $0.028 \pm 0.003$ $\mathrm{w} / \mathrm{o}$ oxygen indicating that the thorium was originally saturated in oxygen. Consequently, this value represents an upper limit for oxygen solubility at $1415 \mathrm{C}$. (2)

\section{Crystallography}

Thorium dioxide, $\mathrm{ThO}_{2}$, has the fluorite structure and is completely soluble with $\mathrm{UO}_{2}$. Solid solutions of the two oxides obey Vegard's law. $(3,4)$

The data tabulated below are from Zachariasen(5). Slowinski(4) reports similar data, giving $a=5.586 \mathrm{~A}$, while Lambertson(3) reports a lattice constant of $\mathrm{a}=5.5961 \pm 0.001 \mathrm{~A}$ for $\mathrm{ThO}_{2}$.

\begin{tabular}{|c|c|c|c|c|c|c|c|}
\hline \multirow[b]{3}{*}{ Phase } & \multicolumn{3}{|c|}{ Unit Cell } & \multirow{2}{*}{\multicolumn{2}{|c|}{$\begin{array}{l}\text { Density, } \\
\mathrm{g} / \mathrm{cm}^{3}\end{array}$}} & \multirow{3}{*}{$\begin{array}{l}\text { Space } \\
\text { Group } \\
\end{array}$} & \multirow[b]{3}{*}{ Remarks } \\
\hline & \multirow[b]{2}{*}{ Type } & \multirow{2}{*}{$\begin{array}{c}\text { Dimensions, } \\
\mathrm{A}\end{array}$} & \multirow{2}{*}{$\begin{array}{c}\begin{array}{c}\text { Number } \\
\text { of }\end{array} \\
\text { Molecules } \\
\end{array}$} & & & & \\
\hline & & & & X-Ray & $\overline{\text { Other }}$ & & \\
\hline $\mathrm{ThO}_{2}$ & Cubic & $a=5.5859 \pm 0.0005$ & 4 & & & & $\begin{array}{l}\text { Fluorite structure, } \\
\text { isomorphous with } \\
\mathrm{UO}_{2}, \mathrm{NpO}_{2}, \mathrm{PuO}_{2} \text {, } \\
\text { and } \mathrm{AmO}_{2}\end{array}$ \\
\hline
\end{tabular}

\section{References}

(1) Brown-Firth Research Laboratories, United Kingdom, unpublished information (March, 1948).

(2) Gerds, A. F., and Mallett, M. W., J. Electrochem. Soc., 101, 171-4 (1954).

(3) Lambertson, W. A., Mueller, M. H., and Gunzel, F. H., Jr., "Uranium Oxide Phase Equilibrium Systems", J. Am. Cer. Soc., 36, 397-9 (1953).

(4) Slowinski, Emil, and Elliott, Norman, "Lattice Constants and Magnetic Susceptibilities of Solid Solutions of Uranium and Thorium Dioxides", Acta Cryst., 5, 768-70 (1952).

(5) Zachariasen, W. H., "Crystal Radii of the Heavy Elements", Phys. Rev. , 73 (9), $1104-5$ (1948).

\section{THORIUM-PHOSPHORUS}

There is evidence of at least two thorium-phosphorus compounds. Meisel(1) examined thorium-phosphorus materials ranging from $\mathrm{ThP}_{0.4}$ to $\mathrm{ThP}_{1.33}$ and reported a subphosphide, composition unknown, and the phosphide $\mathrm{Th}_{3} \mathrm{P}_{4}$.

\section{Crystallography}

The tabulated data are from Meisel ${ }^{(1)}$. Zumbusch ${ }^{(2)}$ has shown that $\mathrm{U}_{3} \mathrm{P}_{4}$ is isomorphous with $\mathrm{Th}_{3} \mathrm{P}_{4}$ and that UP, which has the $\mathrm{NaCl}$ structure, is isomorphous with the thorium subphosphide. 


\section{Unit Cell}

\begin{tabular}{|c|c|c|c|c|c|c|c|}
\hline \multirow[b]{2}{*}{ Phase } & \multirow[b]{2}{*}{ Type } & \multirow{2}{*}{$\begin{array}{c}\text { Dimensions, } \\
\mathrm{A}\end{array}$} & \multirow{2}{*}{$\begin{array}{c}\text { of } \\
\text { Molecules } \\
\end{array}$} & \multicolumn{2}{|c|}{$\mathrm{g} / \mathrm{cm}^{3}$} & \multirow{2}{*}{$\begin{array}{l}\text { Space } \\
\text { Group }\end{array}$} & \multirow[b]{2}{*}{ Remarks } \\
\hline & & & & X-Ray & Other & & \\
\hline Subphosphide & Fcc & $a=5.818 \pm 0.003$ & & & & & Composition unknown \\
\hline $\mathrm{Th}_{3} \mathrm{P}_{4}$ & $\mathrm{Bcc}$ & $a=8.600 \pm 0.002$ & 4 & 8.56 & 8. 44 & $I \overline{4} 3 \mathrm{~d}$ & \\
\hline
\end{tabular}

\section{$\underline{\text { References }}$}

(1) Meisel, Karl, "The Structure of Thorium Phosphides", Z. anorg. u. allgem. Chem., 240, 300-12 (1939).

(2) Zumbusch, Maria, "Structural Analogy of Uranium and Thorium Phosphides", Z. anorg. u. allgem. Chem., 245, 402-8 (1941).

\section{THORIUM-PLUTONIUM}

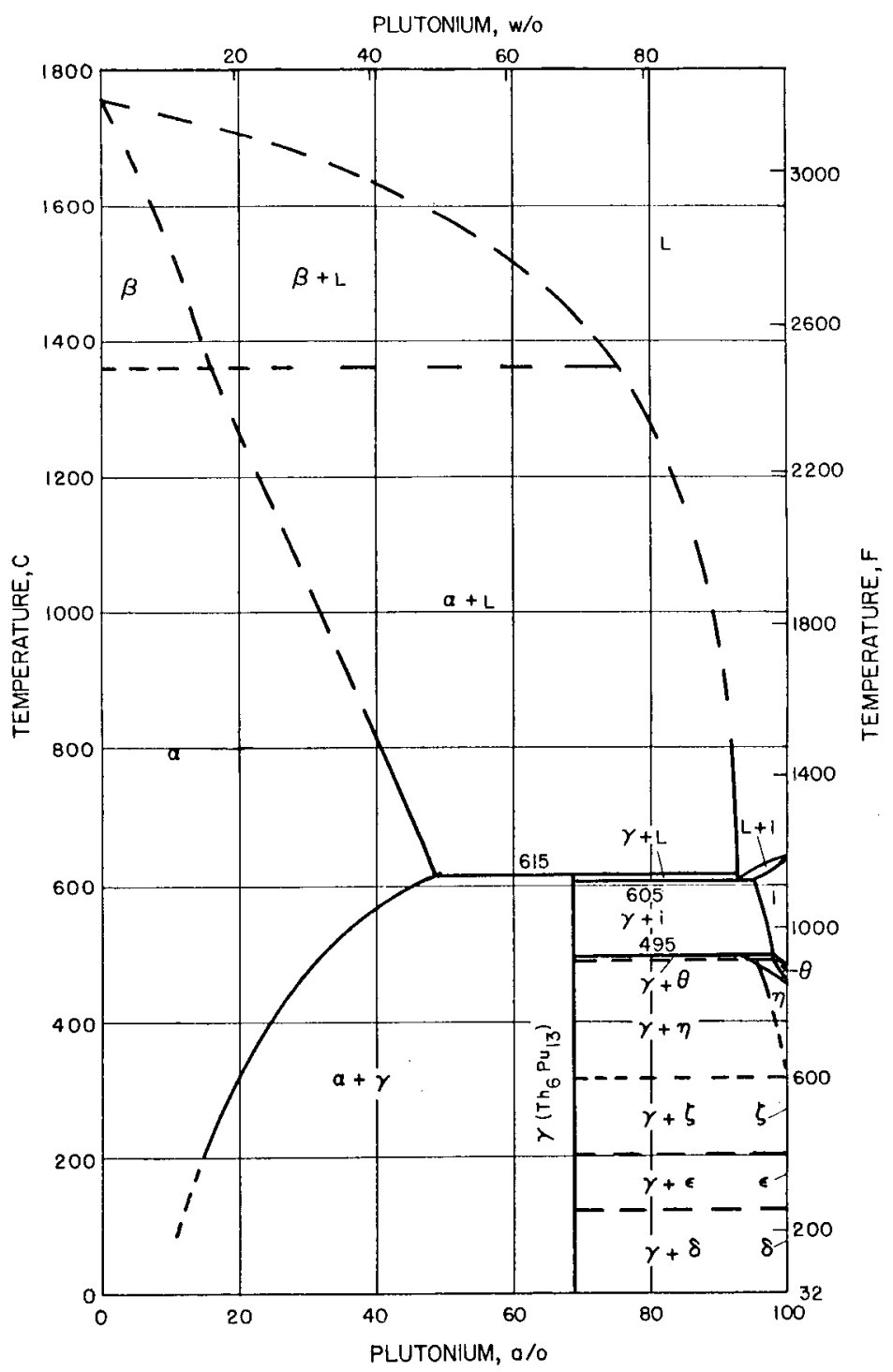




\section{The Constitutional Diagram}

The diagram shown is from Poole, Williamson, and Marples(1). It was derived from $\mathrm{X}-\mathrm{ray}$, metallographic, dilatometric, and thermal-analysis data.

Plutonium dissolves extensively in alpha thorium, as shown, but no data for plutonium solubility in beta thorium were obtained. Very approximate studies of the liquidus suggest that it is nearly horizontal in the region zero to 50 a/o plutonium and subsequently falls very steeply to the eutectic at $605 \mathrm{C}$ and approximately $93 \mathrm{a} / \mathrm{o}$ plutonium.

A maximum solubility of 5 a/o thorium in the eta (delta plutonium) and iota (epsilon plutonium) phases is given. Solubility of thorium in the delta, epsilon, and zeta phases (alpha, beta, and gamma plutonium, respectively) is believed to be small, but phase relationships below $440 \mathrm{C}$ have not been investigated. The eta phase is retained at room temperature, however, even after cooling at $3 \mathrm{C} / \mathrm{min}$.

The formation of gamma, 'T'h6 $\mathrm{Pu}_{13}$, is very sluggish on cooling. Alloys solidified under normal cooling rates were observed to contain alpha thorium and iota (epsilon plutonium). Gama forms subsequently on annealing at about $550 \mathrm{C}$.

Crystallography

\begin{tabular}{|c|c|c|c|c|c|c|c|}
\hline \multirow[b]{3}{*}{ Phase } & \multicolumn{3}{|c|}{ Unit Cell } & \multirow{2}{*}{\multicolumn{2}{|c|}{$\begin{array}{c}\text { Density, } \\
\mathrm{g} / \mathrm{cm}^{3} \\
\end{array}$}} & \multirow{3}{*}{$\begin{array}{l}\text { Space } \\
\text { Group }\end{array}$} & \multirow[b]{3}{*}{ Remarks } \\
\hline & \multirow[b]{2}{*}{ Type } & \multirow{2}{*}{$\begin{array}{c}\text { Dimensions, } \\
\mathrm{A} \\
\end{array}$} & \multirow{2}{*}{$\begin{array}{c}\text { Number } \\
\text { of } \\
\text { Molecules } \\
\end{array}$} & & & & \\
\hline & & & & X-Ray & Other & & \\
\hline $\begin{array}{l}\text { Gamma } \\
\qquad\left(\mathrm{Th}_{6} \mathrm{Pu}_{13}\right)\end{array}$ & Orthorhombic & $\begin{array}{l}a=9.820 \\
b=8.164 \\
c=6.681\end{array}$ & 1 & 13.96 & 14.0 & & \\
\hline
\end{tabular}

\section{Reference}

(1) Poole, D. M., Williamson, G. K. , and Marples, J. A. C. , AERE M/R 2156 (1957); J. Inst. Metals, 86, 172-6 (December, 1957). 


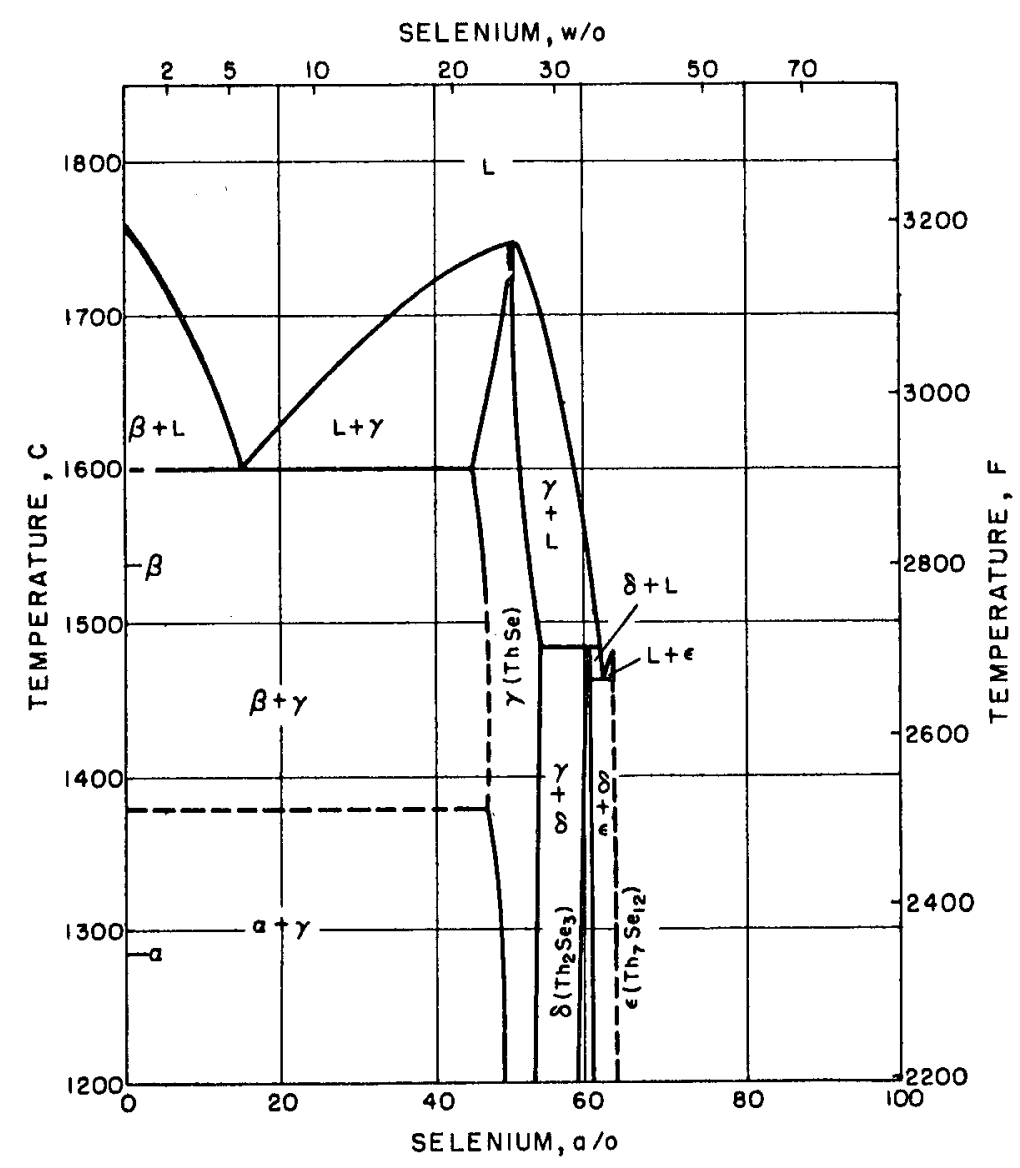

The Constitutional Diagram

According to $D^{\prime} E y e^{(1)}$, there are five intermetallic compounds in the thorium-selenium system. These are $\mathrm{ThSe}, \mathrm{Th}_{2} \mathrm{Se}_{3}, \mathrm{Th}_{7} \mathrm{Se}_{12}, \mathrm{ThSe}_{2}$, and $\mathrm{Th}_{3} \mathrm{Se}_{7}$.

A portion of the system is shown in the accompanying diagram(1). The thorium used in this work contained up to $0.5 \mathrm{w} / 0$ oxygen, and ThOSe was present. Except for the composition range ThSe 0.7 to ThSe 1.1 , ThOSe was observed as a discrete phase and probably does not affect the diagram appreciably. (1) utilized.

The diagram shown is based on experiments in which a variety of techniques were

\section{Crystallography}

The crystallography of the thorium selenides is summarized in the accompanying tabulation. No data are available for $\mathrm{Th}_{3} \mathrm{Se}_{7}$, although crystals of this compound were isolated by subliming selenium from selenium-rich samples.

The structure of ThOSe, which was present as an extraneous phase in part of the work, is tetragonal with $\mathrm{a}=4.038 \pm 0.005 \mathrm{~A}$, and $\mathrm{c}=7.019 \pm 0.005 \mathrm{~A}$. It has two molecules per unit cell in the space group $\mathrm{P} 4 / \mathrm{nmm}, \mathrm{PbFCl-type} \mathrm{structure.}$ 


\begin{tabular}{|c|c|c|c|c|c|c|}
\hline \multirow[b]{3}{*}{ Phase } & \multicolumn{3}{|c|}{ Unit Cell } & \multirow[b]{2}{*}{$\begin{array}{c}\text { Density, } \\
\mathrm{g} / \mathrm{cm}^{3} \\
\end{array}$} & \multirow{3}{*}{$\begin{array}{l}\text { Space } \\
\text { Group }\end{array}$} & \multirow[b]{3}{*}{ Remarks } \\
\hline & \multirow[b]{2}{*}{ Type } & \multirow{2}{*}{$\begin{array}{c}\text { Dimensions, } \\
\mathrm{A} \\
\end{array}$} & \multirow{2}{*}{$\begin{array}{c}\begin{array}{c}\text { Number } \\
\text { of } \\
\text { Molecules }\end{array} \\
\end{array}$} & & & \\
\hline & & & & X-Ray Other & & \\
\hline $\begin{array}{l}\text { Gamma } \\
\text { (ThSe) }\end{array}$ & $\mathrm{Fcc}$ & $a=5.875 \pm 0.002$ & 4 & & & $\begin{array}{l}\mathrm{NaCl} \text {-type } \\
\text { structure }\end{array}$ \\
\hline $\begin{array}{l}\text { Delta } \\
\qquad\left(\mathrm{Th}_{2} \mathrm{Se}_{3}\right)\end{array}$ & $\begin{array}{l}\text { Ortho- } \\
\text { rhombic }\end{array}$ & $\begin{array}{l}\mathrm{a}=11.34 \pm 0.05 \\
\mathrm{~b}=11.57 \pm 0.05 \\
\mathrm{c}=4.27 \pm 0.01\end{array}$ & 4 & & & $\begin{array}{r}\mathrm{Sb}_{2} \mathrm{~S}_{3} \text {-type } \\
\text { structure }\end{array}$ \\
\hline $\begin{array}{l}\text { Epsilon } \\
\qquad\left(\mathrm{Th}_{7} \mathrm{Se}_{12}\right)\end{array}$ & Hexagonal & $\begin{array}{l}a=11.569 \\
c=4.23 \pm 0.01\end{array}$ & 1 & & $\mathrm{P} 63 / \mathrm{m}$ & $\begin{array}{l}\text { Isomorphous } \\
\text { with } \mathrm{Th}_{7} \mathrm{~S}_{12}\end{array}$ \\
\hline $\begin{array}{l}\text { Zeta } \\
\left(\mathrm{ThSe}_{2}\right)\end{array}$ & $\begin{array}{l}\text { Ortho- } \\
\text { rhombic }\end{array}$ & $\begin{array}{l}a=4.420 \pm 0.002 \\
b=7.610 \pm 0.002 \\
c=9.064 \pm 0.002\end{array}$ & 4 & & Pmnb & $\begin{array}{l}\text { Isomorphous } \\
\text { with } \mathrm{ThS}_{2}\end{array}$ \\
\hline
\end{tabular}

Eta No data available

$\left(\mathrm{Th}_{3} \mathrm{Se}_{7}\right)$

References

(1) D'Eye, R. W. M. , Sellman, P. G., and Murray, J. R., "The Thorium-Selenium System", J. Chem. Soc. (London), 2555-62 (1952).

(2) D'Eye, R. W. M., "The Crystal Structures of ThSez and Th7 $\mathrm{Se}_{12}$ ", J. Chem. Soc. (London), 1670-72 (1953).

\section{THORIUM-SILICON}

There is evidence of at least four intermetallic compounds in the thorium-silicon system. Zachariasen( 1$)$ reports alpha and beta $\mathrm{ThSi}_{2}$ and $\mathrm{Th}_{3} \mathrm{Si}_{2}$ while Brauer(2) has reported only the alpha ThSi2 compound. Jacobson(3) reports $\mathrm{Th}_{3} \mathrm{Si}_{2}$ in addition to the three forms given by Zachariasen.

There is a eutectic at the thorium end of the system. Foote(4) gives its location as 10 a/o silicon at a temperature above $1300 \mathrm{C}$.

\section{Crystallography}

The data for alpha $T h i_{2}$ are from Brauer(2), for beta $\mathrm{ThSi}_{2}$ from Zachariasen(1), and for ThSi and $\mathrm{Th}_{3} \mathrm{Si}_{2}$ from Jacobson(3).

\begin{tabular}{|c|c|c|c|c|c|c|c|}
\hline \multirow[b]{3}{*}{ Phase } & \multicolumn{3}{|c|}{ Unit Cell } & & & \multirow{3}{*}{$\begin{array}{l}\text { Space } \\
\text { Group } \\
\end{array}$} & \multirow[b]{3}{*}{ Remarks } \\
\hline & \multirow[b]{2}{*}{ Type } & \multirow{2}{*}{$\begin{array}{c}\text { Dimensions, } \\
\mathrm{A}\end{array}$} & \multirow{2}{*}{$\begin{array}{c}\begin{array}{c}\text { Number } \\
\text { of } \\
\text { Molecules }\end{array} \\
\end{array}$} & \multicolumn{2}{|c|}{$\begin{array}{l}\text { Density, } \\
\mathrm{g} / \mathrm{cm}^{3}\end{array}$} & & \\
\hline & & & & X-Ray & Other & & \\
\hline $\begin{array}{l}\text { Alpha } \\
\text { ThSi }\end{array}$ & $\begin{array}{l}\text { Bc tetrag- } \\
\text { onal }\end{array}$ & $\begin{array}{l}a=4.126 \\
c=14.346\end{array}$ & 4 & 7.79 & 7.63 & I4/amd & $\begin{array}{l}\text { Isomorphous with } \\
\text { alpha USi2 }\end{array}$ \\
\hline $\begin{array}{l}\text { Beta } \\
\text { ThSi2 }\end{array}$ & Hexagonal & $\begin{array}{l}a=3.986 \\
c=4.227\end{array}$ & & & & & $\begin{array}{l}\text { Appears to be simi- } \\
\text { lar to beta USi }\end{array}$ \\
\hline $\mathrm{Th}_{3} \mathrm{Si}_{2}$ & Tetragonal & $\begin{array}{l}a=7.835 \\
c=4.154\end{array}$ & 4 & & & $\mathrm{P} 4 / \mathrm{mbm}$ & $\begin{array}{l}\text { Is omorphous with } \\
\mathrm{U}_{3} \mathrm{Si}_{2} \text { and } \mathrm{Th}_{3} \mathrm{Al}_{2}\end{array}$ \\
\hline ThSi & $\begin{array}{l}\text { Ortho- } \\
\text { rhombic }\end{array}$ & $\begin{array}{l}a=5.89 \\
b=7.88 \\
c=4.15\end{array}$ & 4 & & & Pbnm & $\begin{array}{l}\text { Isomorphous with } \\
\text { FeB, USi, PuSi }\end{array}$ \\
\hline
\end{tabular}




\section{References}

(1) Zachariasen, W. H., unpublished information (August, 1953).

(2) Brauer, G., and Mitius, A., "The Crystal Structure of ThSi 2 ", Z. anorg. u. allgem. Chem., 249, 325-39 (1942).

(3) Jacobson, E. L., Freeman, R. D., Tharp, A. G., and Searcy, A. W., "Preparation, Identification, and Chemical Properties of the Thorium Silicides", J. Am. Chem. Soc., $78,4850(1956)$.

(4) Foote, F., Metallurgy Division Progress Report, CT -2794 (March 27, 1945).

\section{THORIUM-SILVER}

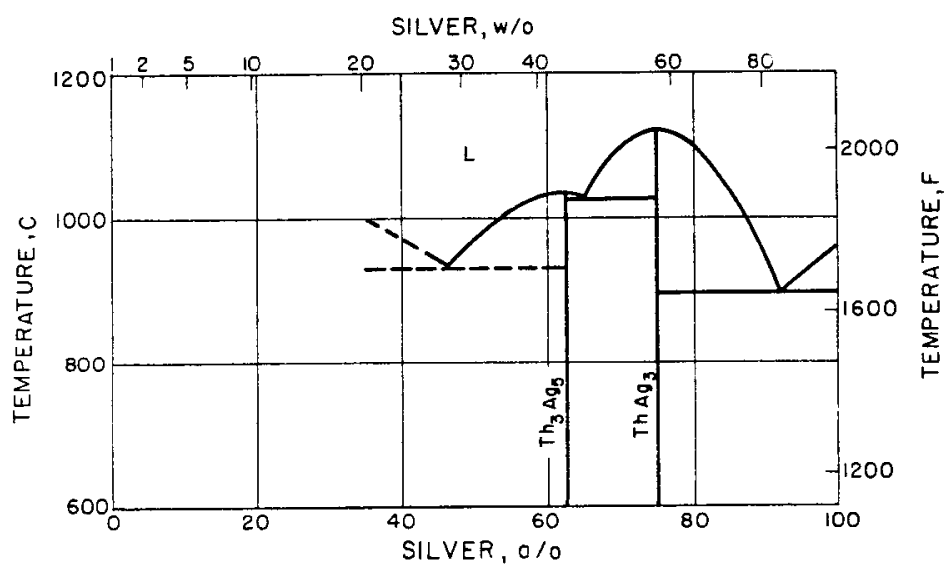

The Constitutional Diagram

The portion of this system which is shown is from Raub(1). An additional pyrophoric thorium-rich compound, $\mathrm{Th}_{2} \mathrm{Ag}$, is reported by Murray(2).

The solid solubility in silver is less than $0.2 \mathrm{w} / \mathrm{o}$ thorium. (1)

The compound $\mathrm{Th}_{3} \mathrm{Ag}_{5}$ is pyrophoric. (1)

\section{Crystallography}

The crystal structure of $\mathrm{Th}_{2} \mathrm{Ag}$ has been reported by Murray (2).

\begin{tabular}{|c|c|c|c|c|c|c|c|}
\hline \multirow[b]{3}{*}{ Phase } & \multicolumn{3}{|c|}{ Unit Cell } & \multirow{2}{*}{\multicolumn{2}{|c|}{$\begin{array}{r}\begin{array}{c}\text { Density, } \\
\mathrm{g} / \mathrm{cm}^{3}\end{array} \\
\end{array}$}} & \multirow{3}{*}{$\begin{array}{l}\text { Space } \\
\text { Group } \\
\end{array}$} & \multirow[b]{3}{*}{ Remarks } \\
\hline & & Dimensions, & $\begin{array}{c}\text { Number } \\
\text { of }\end{array}$ & & & & \\
\hline & Type & $\mathrm{A}$ & Molecules & X-Ray & Other & & \\
\hline $\mathrm{Th}_{2} \mathrm{Ag}$ & Tetragonal & $\begin{array}{l}a=7.56 \\
c=5.84\end{array}$ & 4 & & & $\mathrm{I} 4 / \mathrm{mcm}$ & $\begin{array}{l}\text { Isomorphous with } \\
\mathrm{CuAl}_{2}, \mathrm{Th}_{2} \mathrm{Al} \text {, } \\
\text { and } \mathrm{Th}_{2} \mathrm{Au}\end{array}$ \\
\hline
\end{tabular}

References

(1) Raub, E., Z. Metallkunde, 40 (1949).

(2) Murray, J. R., "The Crystal Structure of Some Thorium Compounds", J. Inst. Metals, 4, $91-6(1955)$. 


\section{THORIUM-SODIUM}

A partial diagram has been reported for this system by Grube and Botzenhardt(1) which showed extensive solubility of thorium in sodium and the presence of an intermetallic compound. Later work by Kelman(2) has shown, however, that this early work is in error.

Numerous tests show that thorium is not attacked by sodium at temperatures of 650 to $800 \mathrm{C}$ or by sodium-potassium mixtures at temperatures from 300 to $900 \mathrm{C}(2)$.

\section{Crystallography}

It is uncertain whether compounds may exist in this system.

\section{References}

(1) Grube, G., and Botzenhardt, L., "The Alloys of Thorium With Copper, Aluminum, and Sodium", Z. Elektrochem., 48, 422 (1942).

(2) Kelman, L., private communication (1955).

\section{THORIUM-SULFUR}

Four sulfides of thorium have been identified: ThS, $\mathrm{Th}_{2} \mathrm{~S}_{3}, \mathrm{Th}_{7} \mathrm{~S}_{12}$, and $\mathrm{ThS}_{2} \cdot(1,2)$ The sulfide $\mathrm{Th}_{7} \mathrm{~S}_{12}$ is reported to have solubility limits of $\mathrm{ThS}_{1,71}$ to $\mathrm{ThS}_{1.76}$. The melting points of the sulfides are as follows:

$\begin{array}{ll}\text { ThS } & 2200 \mathrm{C} \\ \mathrm{Th}_{2} \mathrm{~S}_{3} & 1950 \pm 50 \mathrm{C} \\ \mathrm{Th}_{7} \mathrm{~S}_{12} & 1770 \pm 30 \mathrm{C} \\ \mathrm{ThS}_{2} & 1905 \pm 30 \mathrm{C}\end{array}$

No other data on the constitution of this system are available.

Erystallography

The crystallography of the thorium sulfides has been studied by Zachariasen $(2,3)$ and is tabulated below.

A report in the literature ${ }^{(4)}$, indicating a sulfide of $\mathrm{ThS}_{0} 5$ to $\mathrm{ThS}_{0} .75$ with a defect $\mathrm{NaCl}$ structure, has been shown to be in error. Zachariasen(2) has shown that $\mathrm{ThS}_{0.835}$ contains metallic thorium and that the monosulfide is characterized by a thorium-sulfur ratio of 1.0 .

The lattice constants of the sulfide $\mathrm{Th}_{7} \mathrm{~S}_{12}$ have been shown to vary with composition over the range $T h S_{1,71}$ to $T h S_{1.76}$. The data indicate that this is a defect structure from which thorium atoms can be removed without destroying the stability of the phase. There is not room for more than 12 sulfur atoms per unit cell(3).

$D^{\prime} E y e^{(5)}$ has shown that the thorium sulfides are isomorphous in each case with corresponding selenides. An additional polyselenide, $\mathrm{Th}_{3} \mathrm{Se}_{7}$, to which no sulfide corresponds, was found: 


\begin{tabular}{|c|c|c|c|c|c|c|c|}
\hline \multirow[b]{3}{*}{ Phase } & \multicolumn{3}{|c|}{ Unit Cell } & & & \multirow{3}{*}{$\begin{array}{l}\text { Space } \\
\text { Group }\end{array}$} & \multirow[b]{3}{*}{ Remarks } \\
\hline & \multirow[b]{2}{*}{ Type } & \multirow{2}{*}{$\begin{array}{c}\text { Dimensions, } \\
\text { A } \\
\end{array}$} & \multirow{2}{*}{$\begin{array}{c}\begin{array}{c}\text { Number } \\
\text { of } \\
\text { Molecules }\end{array} \\
\end{array}$} & \multicolumn{2}{|c|}{$\begin{array}{c}\begin{array}{c}\text { Density, } \\
\mathrm{g} / \mathrm{cm}^{3}\end{array} \\
\end{array}$} & & \\
\hline & & & & $\underline{\mathrm{X}-\mathrm{Ray}}$ & Other & & \\
\hline ThS & $F c c$ & $a=5.682 \pm 0.002$ & 4 & 9.56 & & & $\begin{array}{l}\text { Isomorphous with US } \\
\text { and CeS }\end{array}$ \\
\hline $\mathrm{Th}_{2} \mathrm{~S}_{3}$ & $\begin{array}{l}\text { Ortho- } \\
\text { rhombic }\end{array}$ & $\begin{array}{l}a=10.99 \pm 0.05 \\
b=10.85 \pm 0.05 \\
c=3.96 \pm 0.03\end{array}$ & 4 & 7.87 & & $\mathrm{Pbnm}$ & $\begin{array}{l}\mathrm{Sb}_{2} \mathrm{~S}_{3} \text {-type structure, } \\
\text { isomorphous with } \\
\mathrm{Np}_{2} \mathrm{~S}_{3} \text { and } \mathrm{U}_{2} \mathrm{~S}_{3}\end{array}$ \\
\hline $\mathrm{Th}_{7} \mathrm{~S}_{12}$ & $\begin{array}{l}\text { Hexag- } \\
\text { onal }\end{array}$ & $\begin{array}{l}a=11.063 \pm 0.001 \\
c=3.991 \pm 0.001\end{array}$ & 1 & 7.88 & 7.73 & $\mathrm{P}_{3} / \mathrm{m}$ & \\
\hline $\mathrm{ThS}_{2}$ & $\begin{array}{l}\text { Ortho- } \\
\text { rhombic }\end{array}$ & $\begin{array}{l}a=4.268 \pm 0.002 \\
b=7.264 \pm 0.003 \\
c=8.617 \pm 0.003\end{array}$ & 4 & 7.36 & & Pmnb & $\mathrm{PbCl}_{2}$-type structure \\
\hline
\end{tabular}

\section{References}

(1) Eastman, E. D., Brewer, Leo, Bromley, L. A., Gilles, P. W., and Lofgren, N. L., "Preparation and Properties of the Sulfides of Thorium and Uranium", J. Am. Chem. Soc. 72, 4019-23 (1950).

(2) Zachariasen, W. H., "Crystal Chemical Studies of the 5 f-Series of Elements X. Sulfides and Oxysulfides", Acta Cryst., 2, 291-6 (1949).

(3) Zachariasen, W. H., "Crystal Chemical Studies of the 5 f-Series of Elements IX. The Crystal Structure of Th7 12 ", Acta Cryst., 2, 288-91 (1949).

(4) Strotzer, E. F., and Zumbusch, M., Z. anorg. u. allgem. Chem., 247, 415 (1941).

(5) D'Eye, R. W. M., Sellman, P. G., and Murray, J. R., "The Thorium-Selenium System", J. Chem. Soc. (London), 2555-62 (1952).

\section{THORIUM-TANT ALUM}

Wilhelm ${ }^{(1)}$ examined thorium and tantalum after reaction at $2000 \mathrm{C}$ and found only alpha thorium, tantalum and thorium dioxide by X-ray diffraction examination. Similar results are reported by Murray and Thomas ${ }^{(2)}$.

Wilhelm reports that the solubility of thorium in tantalum is quite limited. This report is based on a determination of the lattice coefficients of the tantalum solid solution. No reliable data are available on the solubility of tantalum in thorium. Chiotti ${ }^{(3)}$ reports that thorium is gettered by additions of tantalum.

\section{Crystallography}

No intermetallic compounds occur in this system.

\section{References}

(1) Wilhelm, H. A., Newton, A. S., Daane, A. H., and Neher, C., "Thorium Metallurgy", CT-3714 (February, 1946).

(2) Murray, J. R., and Thomas, C. H., Unitea Kingdom, unpublished information (1957).

(3) Chiotti, P., private communication (March, 1954). 


\section{THORIUM-TELLURIUM}

$D^{\prime E y e}{ }^{(1)}$ has reported the existence of three intermetallic compounds in this system ThTe $\mathrm{ThTe}_{2}$, and $\mathrm{Th}_{3} \mathrm{Te}_{8}$ which all decompose below $1000 \mathrm{C}$ to thorium and tellurium.

An additional compound, nominally assigned the stoichiometry of $\mathrm{Th}_{3} \mathrm{Te}$ has also been reported(2).

\section{Crystallography}

No details are available for either $\mathrm{ThTe}_{2}$ or $\mathrm{Th}_{3} \mathrm{Te}_{8}$; both gave complex diffraction patterns(1). The structure of ThOTe which was present as an extraneous pirase is tetragonal with $\mathrm{a}=4.120$ and $\mathrm{c}=9.564 \mathrm{~A}$. It has two molecules per unit cell in the space group $\mathrm{P} 4 / \mathrm{nmn}$ and is isostructural with ThOSe and ThOS.

\begin{tabular}{|c|c|c|c|c|c|c|c|}
\hline \multirow[b]{3}{*}{ Phase } & \multicolumn{3}{|c|}{ Unit Cell } & \multirow{2}{*}{\multicolumn{2}{|c|}{$\begin{array}{l}\text { Density, } \\
\mathrm{g} / \mathrm{cm}^{3}\end{array}$}} & \multirow{3}{*}{$\begin{array}{l}\text { Space } \\
\text { Group }\end{array}$} & \multirow[b]{3}{*}{ Remarks } \\
\hline & & Dimensions, & $\begin{array}{c}\text { Number } \\
\text { of }\end{array}$ & & & & \\
\hline & Type & A & Molecules & X-Ray & Other & & \\
\hline $\operatorname{ThTe}$ & Cubic & $a=3.826$ & 1 & & & $\mathrm{Pm} 3 \mathrm{~m}$ & $\begin{array}{l}\text { CsCl-type } \\
\text { structure }\end{array}$ \\
\hline
\end{tabular}

\section{References}

(1) D'Eve, R. W. M., and Sellman, P. G., "The Thorium Tellurium System", J. Chem. Soc. (London), 3760 (1954).

(2) Montignie, E., "Tellurides of Uranium, Thorium, and Cerium", Bull. soc. chim. France, 748-9 (1947).

\section{THORIUM-TH ALLIUM}

The solubility of thorium in liquid thallium is reported to increase from $0.27 \mathrm{w} / 0$ at $800 \mathrm{C}$ to $0.33 \mathrm{w} / 0$ at $900 \mathrm{C}^{(1)}$.

Crystallography

No data are available.

$\underline{\text { Reference }}$

(1) Hayes, E. E., and Gordon, P., J. Met. and Cer., TID-65, 130-41 (July, 1948). Classified.

\section{THORIUM-TIN}

The solubility of thorium in liquid tin has been reported as follows: less than $0.05 \mathrm{w} / 0$, $600 \mathrm{C} ; 0.2 \mathrm{w} / 0,700 \mathrm{C} ; 1.9 \mathrm{w} / \mathrm{o}, 800 \mathrm{C}$; and $4.3 \mathrm{w} / 0,900 \mathrm{C}$.

\section{Crystallography}

No data concerning compounds in this system are available.

\section{Reference}

(1) Hayes, E. E., and Gordon, P., J. Met. and Cer., TID-65, 130-4l (July, 1948). Classified. 


\section{THORIUM-TIT ANIUM}

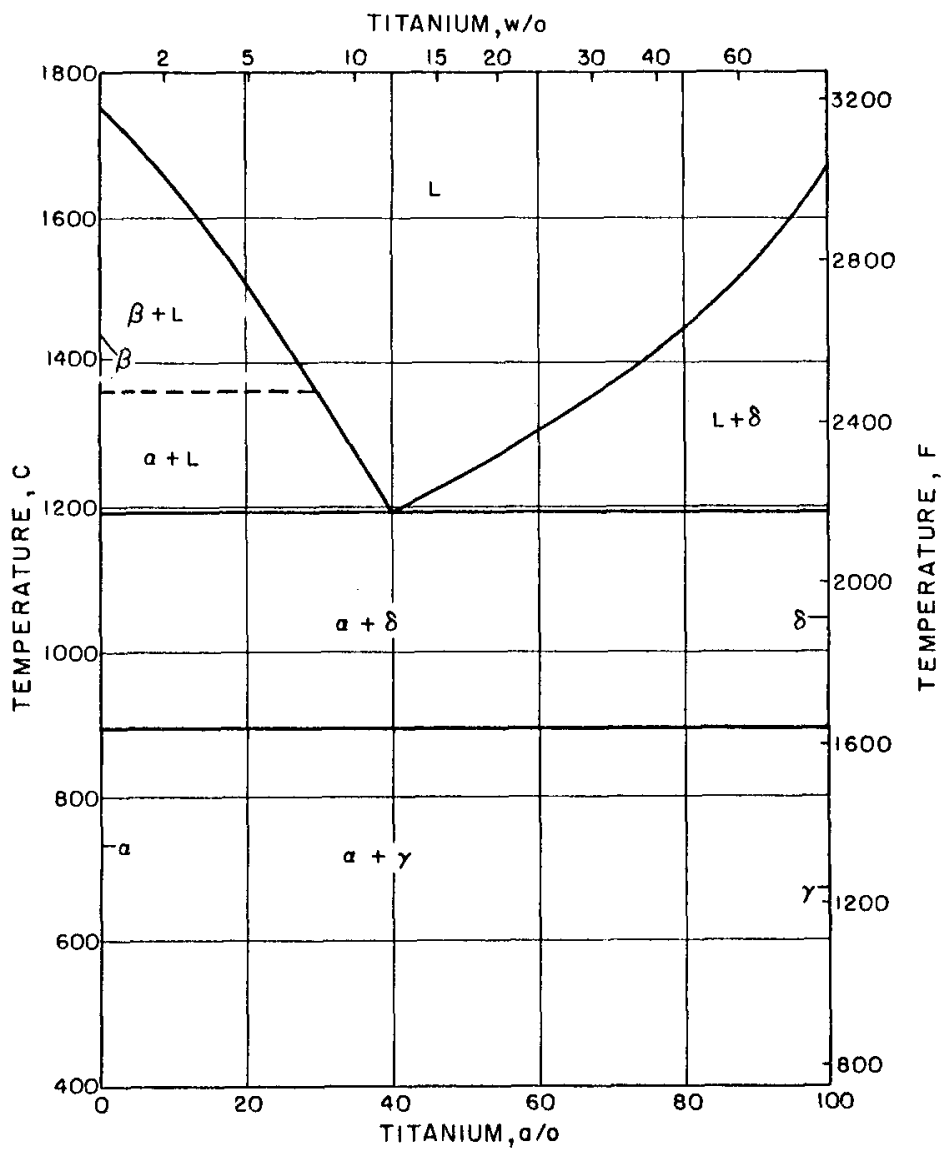

\section{The Constitutional Diagram}

The diagram which is shown has been determined by Carlson (1). It is based on experiments utilizing a variety of methods. These include X-ray diffraction, metallographic examination, thermal analyses, and diffusion experiments.

There are no compounds in this system. A eutectic is formed at $1190 \mathrm{C}$ and $12 \mathrm{w} / 0 \mathrm{ti-}$ tanium. It is reported that the transformation in titanium is unaffected by additions of thorium. (1)

Lattice constants were determined for alloys in this system. The data indicate that the solubility in thorium is probably less than $0.1 \mathrm{w} / \mathrm{o}$ titanium, and the solubility of thorium in titanium is even less. (1)

Since the solubility of titanium in thorium is slight, the re is probably little effect of titanium on the transformation of thorium from alpha to beta. Chiotti $(2)$ reports that titanium getters thorium.

\section{Crystallography}

There are no compounds in the thorium-titanium system.

\section{References}

(1) Carlson, O. N., Dickinson, J. M., Lunt, H. E., and Wilhelm, H. A., "ThoriumColumbium and Thorium-Titanium Alloy Systems", J. Metals, 8, 132-6 (1956).

(2) Chiotti, Premo, private communication (March, 1954). 


\section{THORIUM-TUNGSTEN}

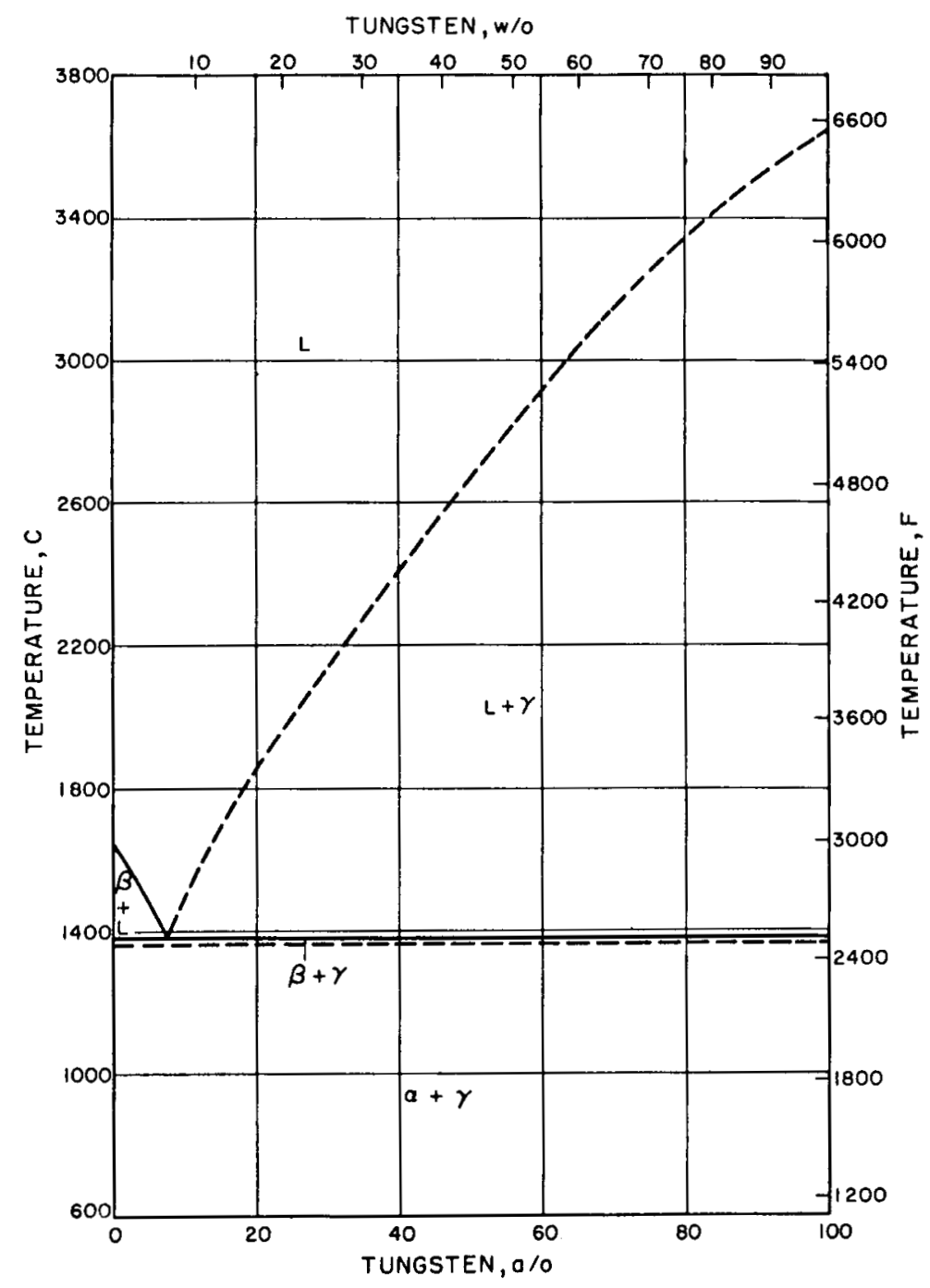

\section{The Constitutional Diagram}

The diagram which is shown was determined by Lloyd and Murray(1). It is based on studies in which a variety of experimental techniques were used. There is little solubility in any of the terminal phases.

This is in general agreement with earlier work of Wilhelm (2), who reported that there were no intermetallic compounds in the system and that the eutectic temperature was $1475 \mathrm{C}$.

\section{Crystallography}

No compounds occur in this system.

\section{$\underline{\text { References }}$}

(1) Lloyd, S. J., and Murray, J. R., United Kingdom, unpublished information (1955).

(2) Wilhelm, H. A., Newton, A. S., Daane, A. H., and Neher, C. , "Thorium Metallurgy", CT-3714 (February, 1946). 


\section{THORIUM-V AN ADIUM}

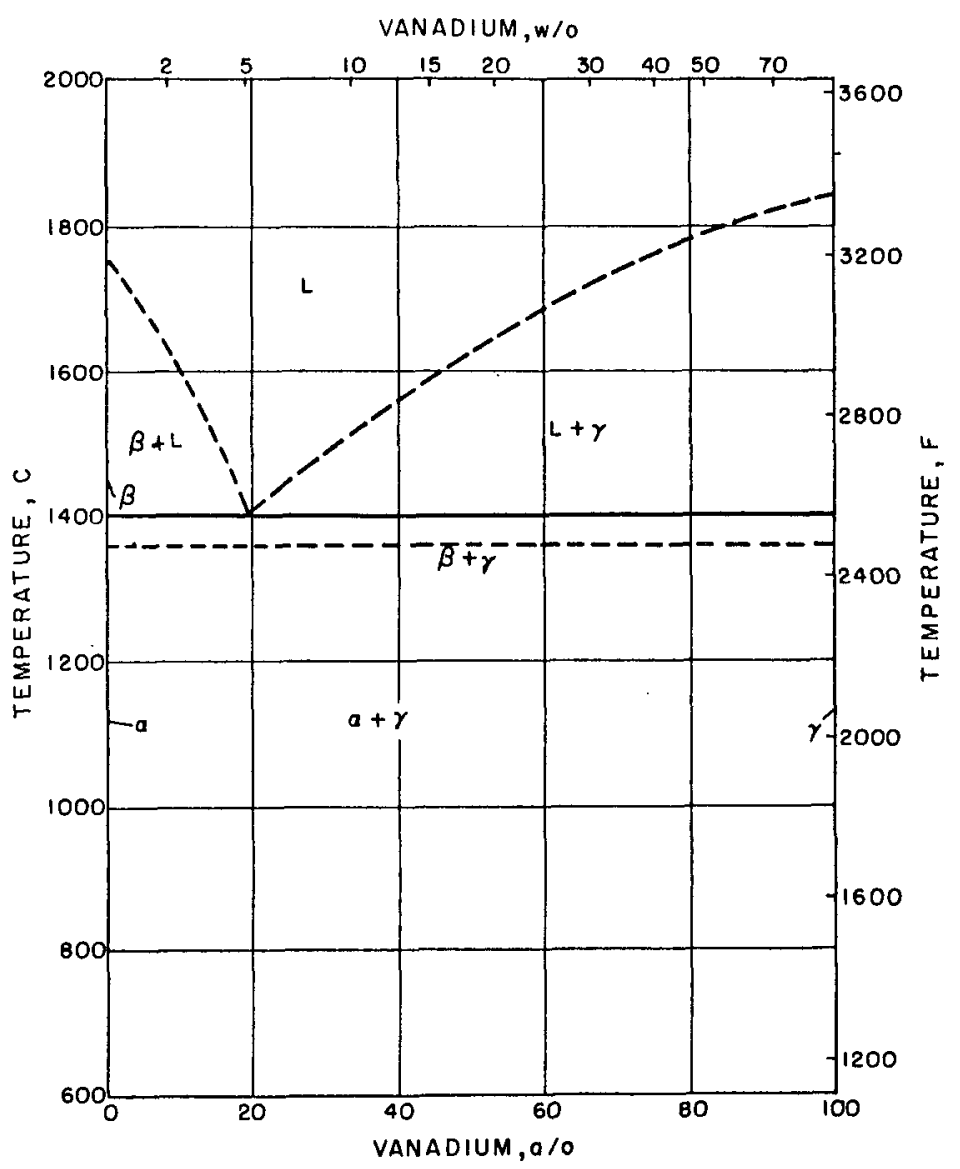

\section{The Constitutional Diagram}

The diagram which is shown has been reported by Levingston and Rogers ${ }^{(1)}$. It is based on studies in which a variety of experimental techniques was used.

There are no compounds in this system. The eutectic reaction is indicated as occurring at $1400 \mathrm{C}$ and $19 \mathrm{a} / \mathrm{o}(5 \mathrm{w} / \mathrm{o})$ vanadium $(1)$, although in a more recent determination $(2)$ the eutectic temperature is reported as $1420 \mathrm{C}$. Vanadium has little effect on the transformation of thorium from alpha to beta(1), the transformation being given as $1360 \mathrm{C}$ in thorium vanadium alloys. (2)

There is little solubility in any of the terminal phases in this system. A specimen of thorium had a lattice parameter of $a=5.087 \pm 0.002 \mathrm{~A}$ when furnace cooled and examined by $\mathrm{X}$-ray diffraction. Specimens of thorium quenched from $1300 \mathrm{C}$ gave a lattice parameter of $a=5.094 \pm 0.004 \mathrm{~A}$. This parameter indicates that only a slight solubility of vanadium in thorium occurs even at high temperatures. (1)

\section{Crystallography}

There are no intermetallic compounds in this system.

\section{References}

(1) Levingston, H. L., and Rogers, B. A., "The Thorium-Vanadium System", AECD-3602 (April 22, 1953).

(2) Wilhelm, H. A., "Nuclear Fuels Newsletter", WASH-704 (December, 1957). Classified. 


\section{THORIUM-ZINC}

Wilhelm $(1)$ has reported a compound, $\mathrm{Th}_{2} \mathrm{Zn}$. It is stable to $1040 \mathrm{C}$, at which temperature it decomposes to form thorium and zinc.

Data are incomplete for the system from $\mathrm{Th}_{2} \mathrm{Zn}_{n}$ to zinc. However, Nowotny (2) has reported that a compound, ThZng, is formed.

Crystallography

Baenziger has reported the data for $\mathrm{Th}_{2} \mathrm{Zn}$, and Nowotny the data for $\mathrm{ThZn}_{9}$ given below.

\begin{tabular}{|c|c|c|c|c|c|c|c|}
\hline \multirow[b]{3}{*}{ Phase } & \multicolumn{3}{|c|}{ Unit Cell } & \multirow{2}{*}{\multicolumn{2}{|c|}{$\begin{array}{c}\begin{array}{c}\text { Density, } \\
\mathrm{g} / \mathrm{cm}^{3}\end{array} \\
\end{array}$}} & \multirow{3}{*}{$\begin{array}{l}\text { Space } \\
\text { Group }\end{array}$} & \multirow[b]{3}{*}{ Remarks } \\
\hline & & Dimensions, & Number of & & & & \\
\hline & Type & $\mathrm{A}$ & Molecules & $X-R a y$ & Other & & \\
\hline $\mathrm{Th}_{2} \mathrm{Zn}$ & $\begin{array}{l}\text { Bc tetrag- } \\
\text { onal }\end{array}$ & $\begin{array}{l}a=7.60 \\
c=5.64\end{array}$ & 4 & 10.6 & & $\mathrm{I} 4 / \mathrm{mcm}$ & $\begin{array}{c}\text { Isomorphous with } \\
\mathrm{CuAl}_{2}, \mathrm{Th}_{2} \mathrm{Al} \\
\mathrm{Th}_{2} \mathrm{Au}, \mathrm{Th}_{2} \mathrm{Cu}\end{array}$ \\
\hline ThZng & Hexagonal & $\begin{array}{l}a=5.24 \\
c=4.45\end{array}$ & 1 & & & $\mathrm{P} 6 / \mathrm{mmm}$ & $\begin{array}{l}\text { Isomorphous with } \\
\mathrm{CaZn}_{5}, \mathrm{ThFe}_{5}, \\
\mathrm{CeZn_{5 }}\end{array}$ \\
\hline
\end{tabular}

\section{References}

(1) Wilhelm, H. A., Newton, A. S., Daane, A. H., and Neher, C., "Thorium Metallurgy", CT-3714 (February, 1946).

(2) Nowotny, H., "Crystal Structure of $\mathrm{ThZn}_{9}, \mathrm{Cd}_{2} \mathrm{Ca}$, and $(\mathrm{AgMg})_{2} \mathrm{Ca}$, Metallforschung, $\underline{1}, 31-4(1946)$.

(3) Baenziger, N. C., Rundle, R. E., and Snow, A. I. , "Structure of the Compounds $\mathrm{Th}_{2} \mathrm{Cu}, \mathrm{ThCu}_{2}$, Th2 $\mathrm{Zn}$, and $\mathrm{ThHg}_{3}$ ", Acta Cryst., 9, 93 (1956).

\section{THORIUM-ZIRCONIUM}

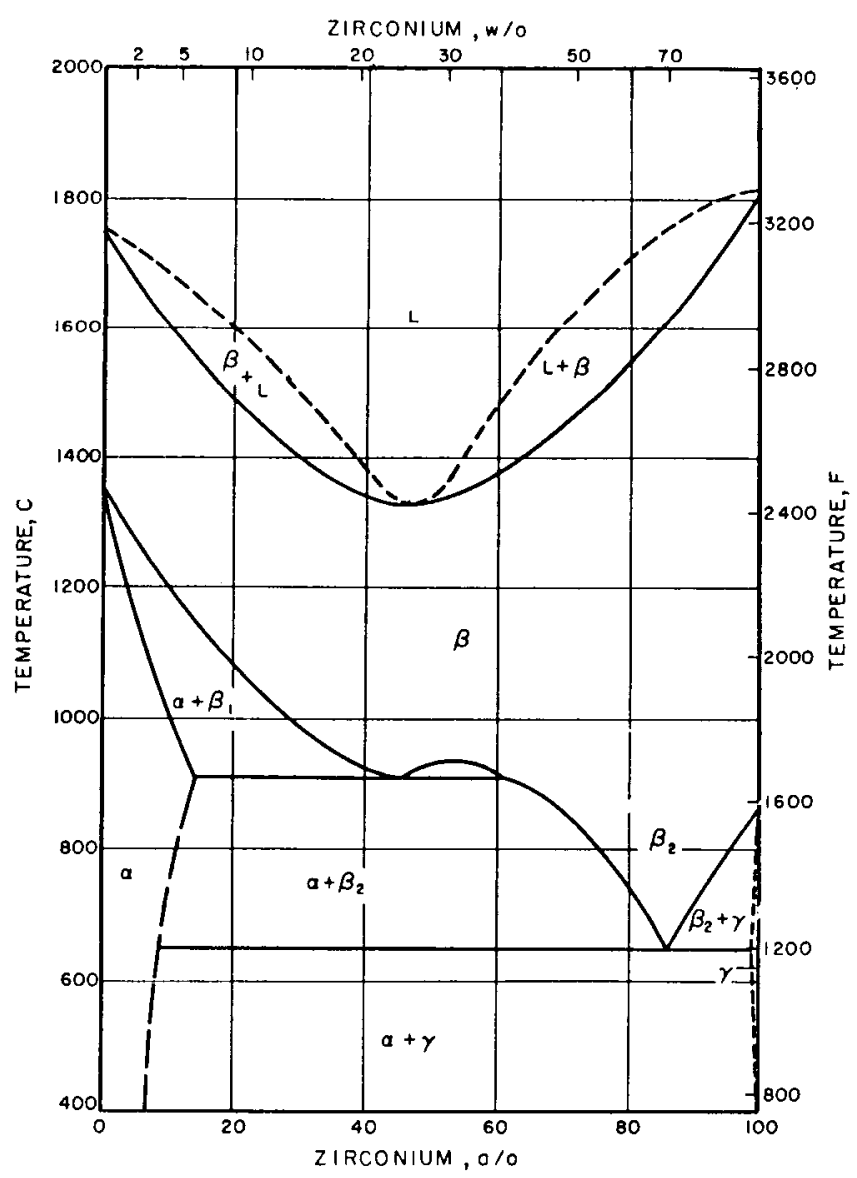


The diagram shown is from Carlson $(1,2)$. It is confirmed in part by the work of Saller and Rough(3). The eutectoid at the zirconium end of the system occurring at $650 \mathrm{C}$ and 14.7 a/o thorium and the minimum in the liquidus is confirmed by Murray (4).

The beta ${ }_{1}$-plus-beta 2 loop shown is based on high-temperature $\mathrm{X}$-ray studies of alloys prepared from sponge thorium and crystal-bar zirconium. Attempts to retain a two-phase microstructure by quenching from within the loop were unsuccessful. (2) Similarly, Murray ${ }^{(4)}$ reports that no evidence of the beta 1 -plus-beta 2 was obtained metallographically in alloys made by arc melting crystal-bar thorium and zirconium. However, in alloys prepared

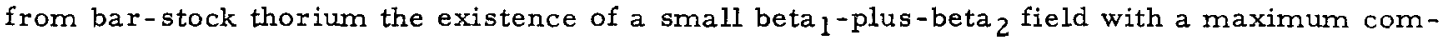
position and temperature range of 38 to 65 a/o zirconium and 915 to $950 \mathrm{C}$, respectively, was observed. These results seem to indicate that in pure binary alloys the immiscibility loop tends to close.

The solubility of zirconium in alpha thorium is based on lattice-parameter measurements (2). The solubility of thorium in gamma (alpha zirconium) is less than 2.2 a/o. (5)

\section{Crystallography}

There are no compounds in the thorium-zirconium system.

\section{References}

(1) Carlson, O. N., "Some Studies of the Uranium-Thorium-Zirconium Ternary System", AECD-3206 (June 5, 1950).

(2) Gibson, E. D., Loomis, B. A, , and Carlson, O. N., "Thorium-Zirconium and ThoriumHafnium Alloy Systems", Trans. ASM, 50 (1958).

(3) Saller, H. A., and Rough, F. A., "Proceedings of Spring Metallurgy Conference", TID5084 (March, 1952). Classified.

(4) Murray, J. R., United Kingdom, unpublished information (1956).

(5) Pfeil, P. C. L., "A Discussion of the Factors Affecting the Constitution of Zirconium Alloys", AERE M/R 960 (June 27, 1952). 


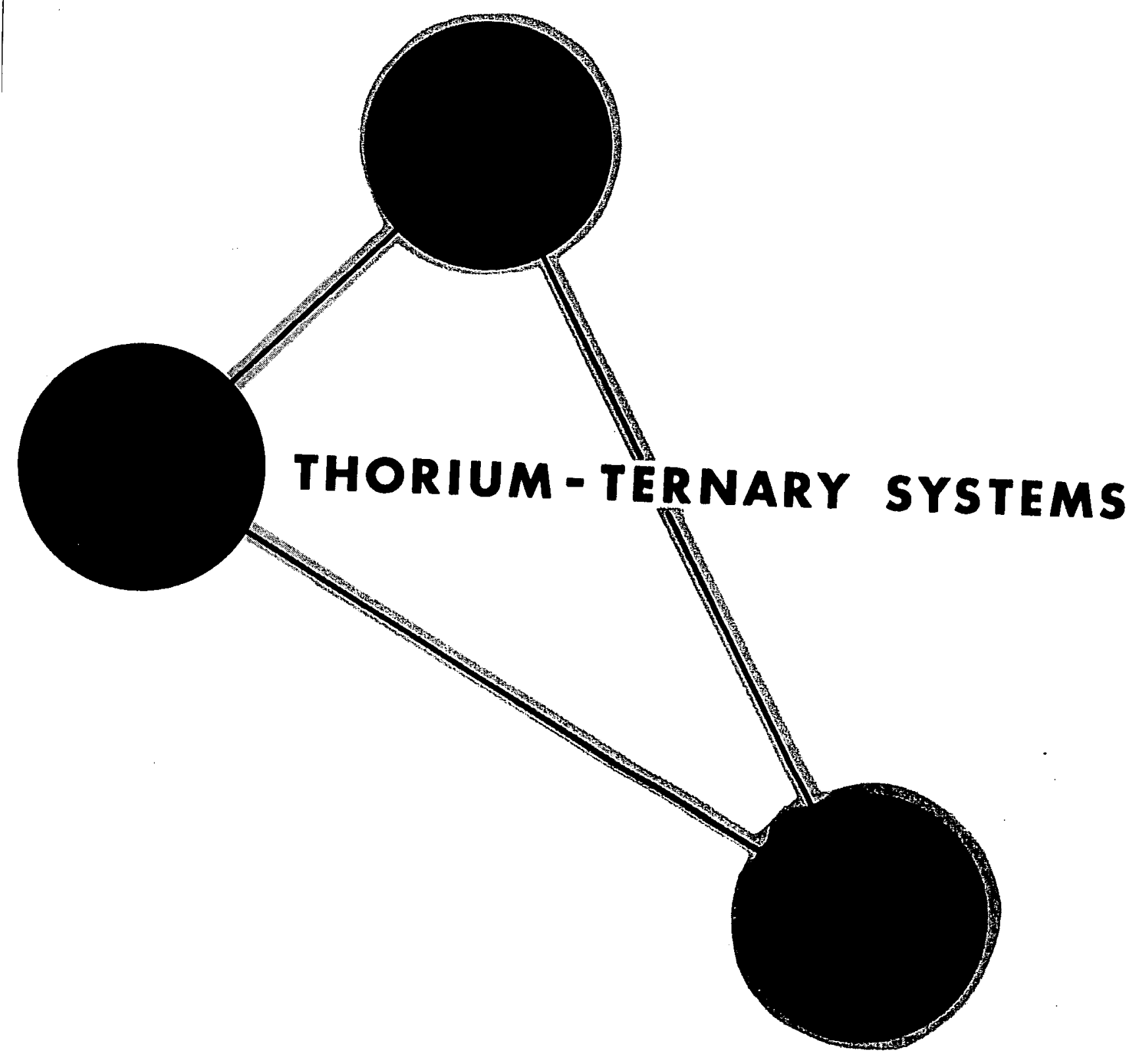




\section{THORIUM-BERYLLIUM-SILICON}

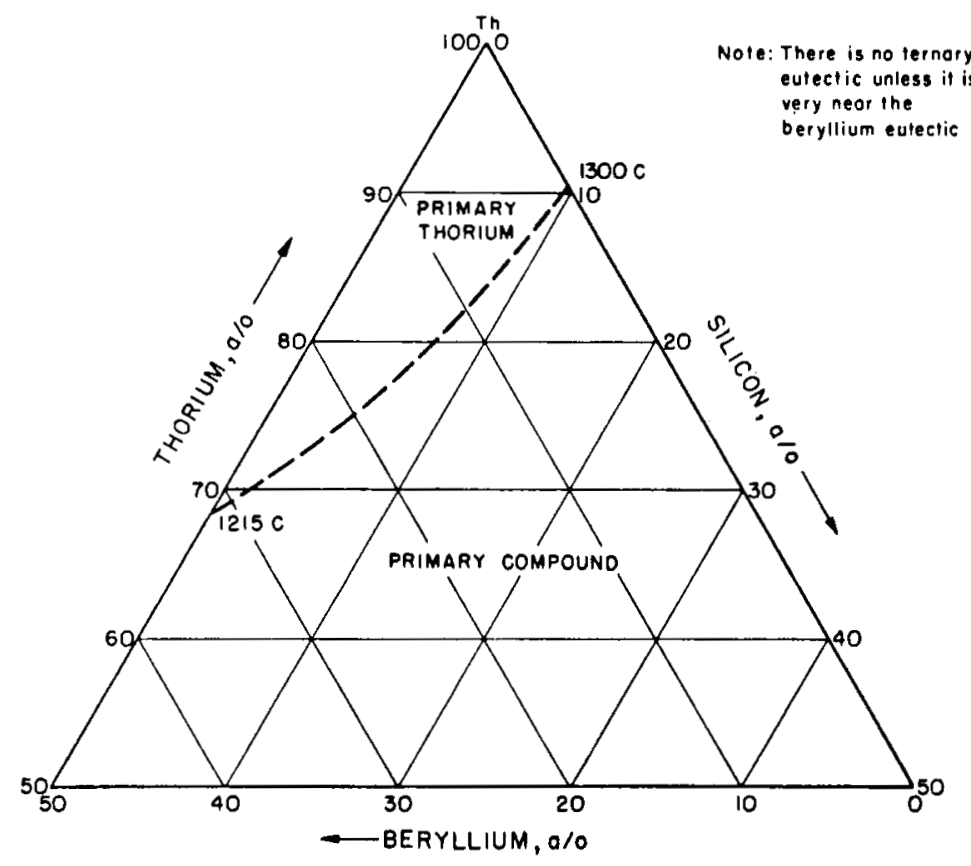

\section{The Constitutional Diagram}

A portion of the liquidus of the thorium-rich alloys has been reported. (1) There is a eutectic trough which slopes from a maximum greater than $1300 \mathrm{C}$ at the thorium-silicon eutectic to the thorium-beryllium eutectic at $1215 \mathrm{C}$. ${ }^{(2)}$

\section{Crystallography}

No new phases are involved in the ternary system.

\section{References}

(1) Foote, F., Metallurgy Division Progress Report, CT-2794 (April, 1945).

(2) Wilhelm, H. A., Newton, A. S., Daane, A. H., and Neher, C., "Thorium Metallurgy", CT-3714 (February, 1946). 


\section{THORIUM-BISMUTH-LEAD}

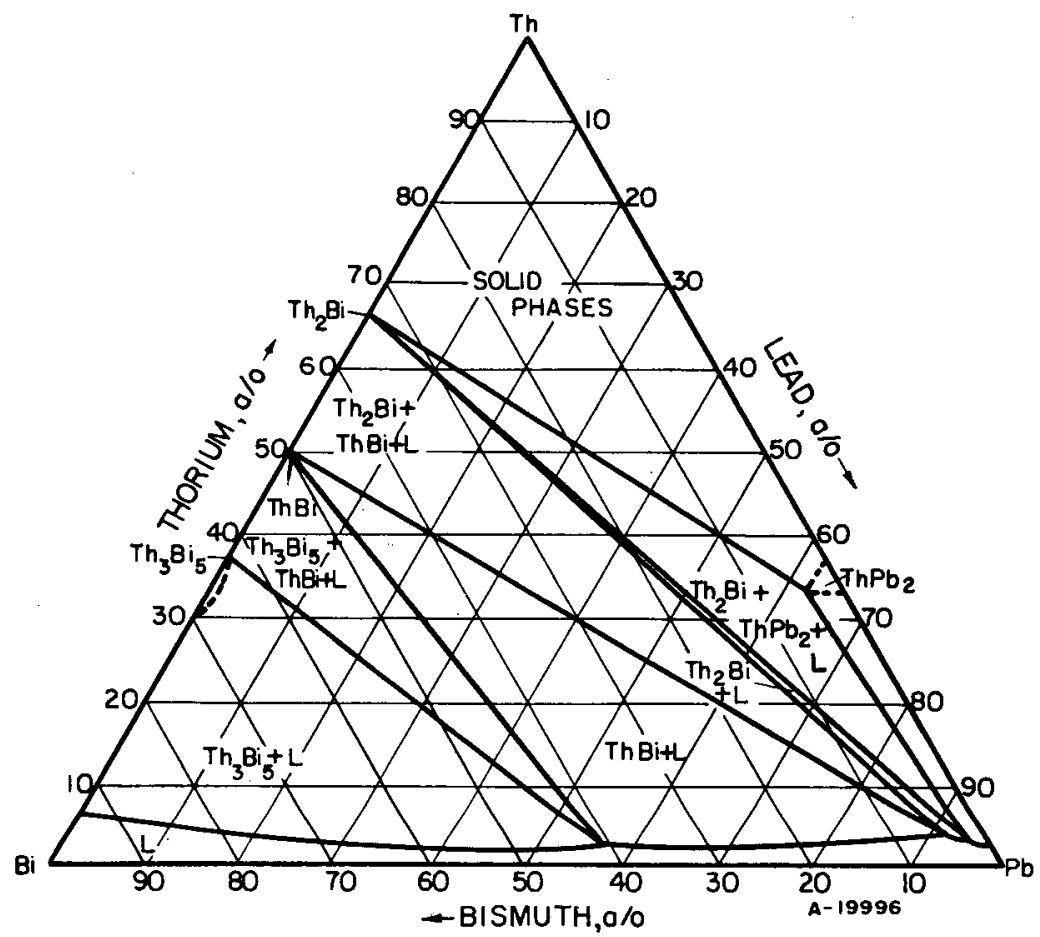

The Constitutional Diagram

An isothermal section determined at $1000 \mathrm{C}$ by Bryner ${ }^{(1)}$ is shown in the accompanying figure. As noted in the thorium binary-diagram section, Ferro ${ }^{(2)}$ has identified the compound shown here as $\mathrm{Th}_{3} \mathrm{Bi}_{5}$ as $\mathrm{Th}_{3} \mathrm{Bi}_{4}$. Consequently, some revision in the diagram shown is undoubtedly required. However, since exact details are unknown, the diagram has been reproduced as originally determined.

Lead lowers the solubility of thorium in bismuth.

\section{Crystallography}

No new phases are involved in the thorium-bismuth-lead system.

\section{References}

(1) Bryner, J. S., and Teitel, R. J., private communication (1956).

(2) Ferro, R., Acta Cryst., 10, 476 (1957). 